LA-8130-MS

$D R .462$

Informal Report

\title{
Application of Oil-Field Well Log Interpretation Techniques to the Cerro Prieto Geothermal Field
}




\section{DISCLAIMER}

This report was prepared as an account of work sponsored by an agency of the United States Government. Neither the United States Government nor any agency Thereof, nor any of their employees, makes any warranty, express or implied, or assumes any legal liability or responsibility for the accuracy, completeness, or usefulness of any information, apparatus, product, or process disclosed, or represents that its use would not infringe privately owned rights. Reference herein to any specific commercial product, process, or service by trade name, trademark, manufacturer, or otherwise does not necessarily constitute or imply its endorsement, recommendation, or favoring by the United States Government or any agency thereof. The views and opinions of authors expressed herein do not necessarily state or reflect those of the United States Government or any agency thereof. 


\section{DISCLAIMER}

Portions of this document may be illegible in electronic image products. Images are produced from the best available original document. 
This report was not edited by the Technical Information staff.

This work was supported by the US Department of Energy, Division of Geothermal Energy.

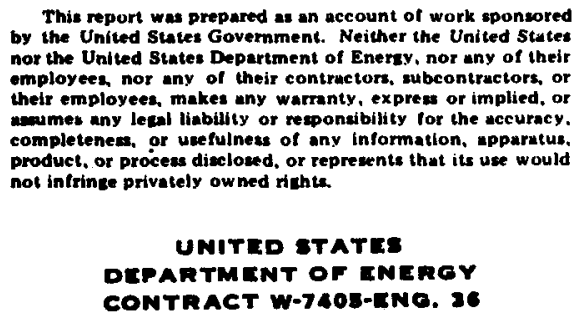


LA-8130-MS

Informal Report

UC.66b

Issued: October 1979

\section{Application of Oil-Field Well Log Interpretation Techniques to the Cerro Prieto Geothermal Field}

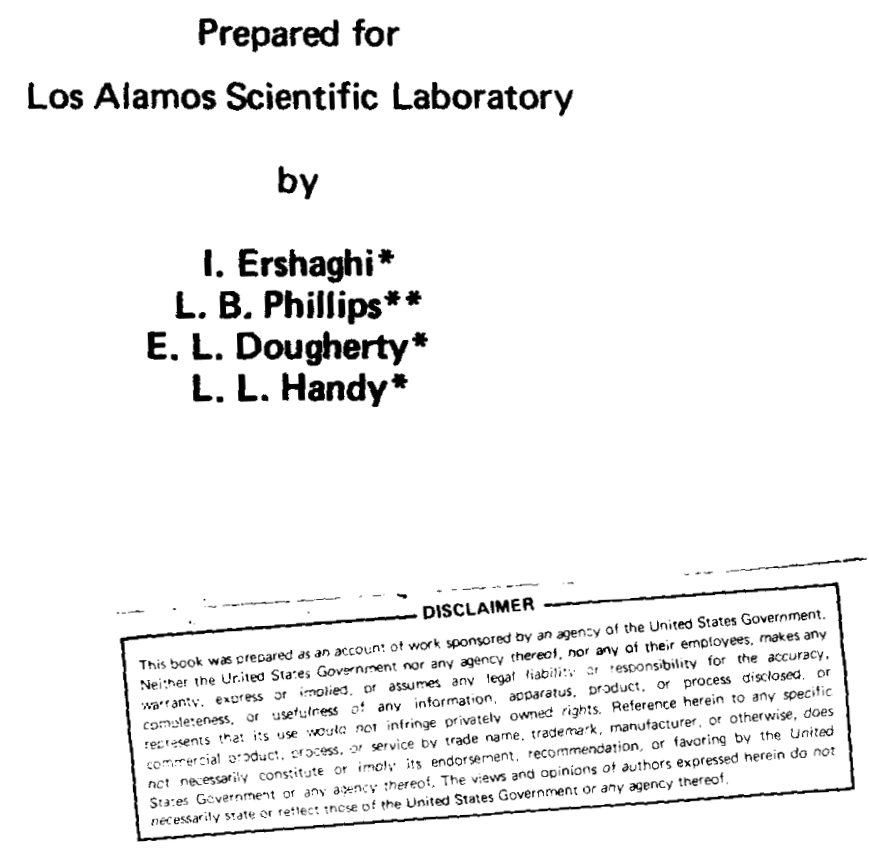

*Department of Petroleum Engineering, University of Southern California, University Park, Los Angeles, CA 90007.

${ }^{* *}$ Chevron Oil Field Research Company, La Habra, CA 90631. 9606872

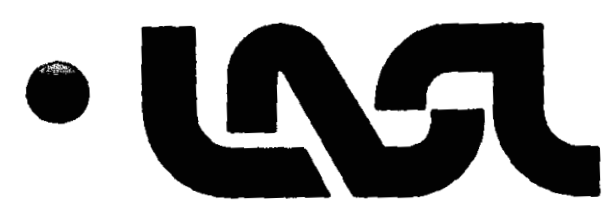

Under Contract L28-1932 E-3

October 1979 
ABBREVIATIONS AND SMMBOLS . . . . . . . . . . . . . . . . 1

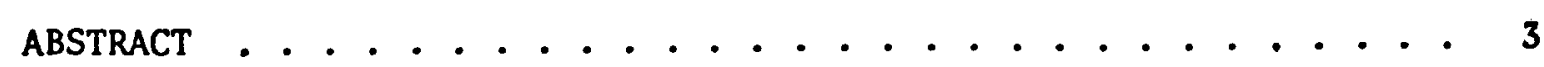

I. INTRODUCTION ....................... . . . 4

II. GEOLOGY OF THE CERRO PRIETO FIELD . . . . . . . . . . . . . . 5

III. DEVELOPMENT . . . . . . . . . . . . . . . . . . 7

IV. OBJECTIVES OF THE STUDY . . . . . . . . . . . . . . . . 7

V. REVIEW OF EXISTING DATA . . . . . . . . . . . . . . 10

vI. METHOD OF STUDY . . . . . . . . . . . . . . . . . . . 11

A. Graphic Studies ... . . . . . . . . . . . . 11

B. Numerical Studies.................... 13

1. The Simulation Program . . . . . . . . . . . . 17

2. Estimation of Formation Water Salinity . . . . . . 18

3. Temperature Profile... . . . . . . . . . . 19

VII. RESULTS OF NUMERICAL STUDIES . . . . . . . . . . . . . . . . 19

VIII. SUMMARY AND CONCLUSIONS . . . . . . . . . . . . . . . 25

ACKNOWLEDGMENTS . . . . . . . . . . . . . . . . . . 28

REFERENCES . . . . . . . . . . . . . . . . . . . . 29

APPENDIX A. REVIEW OF LOG QUALITY . . . . . . . . . . . . . . 31

APPENDIX B. FLOW DIAGRAM OF THE COMPUTER PROGRAM . . . . . . . . . 34

APPENDIX C. SUMMARY OF EQUATIONS . . . . . . . . . . . . . . . 38

APPENDIX D. INDIVIDUAL WELL SUMMARIES . . . . . . . . . . . 42

We11 14

Drilling Report . . . . . . . . . . . . . . 44

SP-Gamma Ray Overlay . . . . . . . . . . . . 52

Computed Results ................ 54

We11 27

Drilling Report ................ 67

SP-Gamma Ray Overlay . . . . . . . . . . . . 73

Computed Results. . . . . . . . . . . . . . . . 81 
We11 29

Drilling Report . . . . . . . . . . . . . . 95

SP-Gamna Ray Overlay . . . . . . . . . . . . 101

Computed Results .................... 105

Wel1 42

Drilling Report . . . . . . . . . . . . . . 118

SP-Gamna Ray Overlay . . . . . . . . . . . . . . 123

Computed Results ..... . . . . . . . . . . . 133 


\section{ABBREVIATIONS AND SYMBOLS}

Symbol

a

$a_{\mathrm{mfe}}$

a we

CNL

$D_{i}$

DIL

F

FDL

$F_{\text {Xo }}$

IES

m

$\mathrm{R}_{\text {ILD }}$

$R_{\text {ILM }}$

$R_{\text {LL8 }}$

$R_{\text {mf }}$

$R_{\mathrm{mfe}}$

$R_{\operatorname{mff}}$

$R_{t}$

R

$R_{\text {wad }}$

$R_{\text {wax }}$

Rely

$R_{\text {wsp }}$

$R_{\mathbf{X O}}$

SP

SALLY

Saraband

S

T

$T_{f}$

VSH

VSGR

\section{Definition}

Constant in $F-\phi$ equation

Equivalent mud filtrate activity

Equivalent formation water activity

Compensated Neutron Log

Diameter of invasion

Dual Induction Laterolog

Formation resistivity factor

Formation Density Log

Formation resistivity factor from flushed zone data

Induction Electric Survey

Cementation factor

Resistivity from Induction Log Deep, ohm-m

Resistivity from Induction Log Medium, ohm-m

Resistivity from Laterolog 8 , ohm-m

Resistivity of mud filtrate, ohm-m

Equivalent resistivity of mud filtrate, ohm-m

Resistivity of mud filtrate at formation temperature, ohm-m

True resistivity of formation, ohm-m

Formation water resistivity, ohm-m

Apparent $R_{W}$ obtained from deep resistivity data, ohm-m

Apparent $R_{w}$ obtained from invaded zone data, ohm-m

Resistivity of fluid associated with clay, ohm-m

Apparent $R_{w}$ obtained from SP Log, ohm-m

Resistivity of invaded zone

Self Potential

Salinity, ppm

Computed Log (Schlumberger Trade Mark)

Water saturation, fraction

Temperature, ${ }^{\circ} \mathrm{C}$ or ${ }^{\circ} \mathrm{F}$

Formation temperature $\left({ }^{\circ} \mathrm{C}\right.$ or $\left.{ }^{\circ} \mathrm{F}\right)$

Shale content, fraction obtained from $\phi_{D}-\phi_{N}$ cross plot

Shale content, fraction (obtained from Gamma Ray) 


$\begin{array}{ll}\phi_{D} & \text { Porosity from Density Log, fraction } \\ \phi_{D C} & \text { Clay porosity from Density Log } \\ \phi_{e} & \text { Effective porosity, fraction } \\ \phi_{N} & \text { Porosity from Neutron Log, fraction } \\ \phi_{N C} & \text { Clay porosity from Neutron Log } \\ \phi_{t} & \text { Total porosity, fraction } \\ \rho_{D C} & \text { Density of Dry Clay }(g / c c) \\ \rho_{m a} & \text { Matrix density, }(g / c c) \\ \rho_{W C} & \text { Density of Wet Clay }(g / c c)\end{array}$


APPLICATION OI: OIL-I:LIELI) WELL LOG INTERPRLTATION

TECHNIQUES TO TH: CLRRO PRIETO GEOTHERMAL FIELD

\author{
by
}

I. Ershaghi, L. B. Phillips,

E. L. Dougherty and L. L. Handy

\begin{abstract}
This study presents an example of the application of oil-field techniques to the Cerro Prieto Field, Mexico. The lithology in this field (sand-shale lithology) is relatively similar to oil-field systems. The study was undertaken as a part of the first series of case studies supported by the Geothermal Log Interpretation Program (GLIP) of the U. S. Department of Energy managed by the Los Alamos Scientific Laboratory.

The suites of logs for individual wells were far from complete. This was partly because of adverse borehole conditions but mostly because of unavailability of hightemperature tools. The most complete set of logs was a combination of Dual Induction Laterolog, Compensated Formation Density Gamma Ray, Compensated Neutron Log, and Saraband. Temperature data about the wells were sketchy, and the logs had been run under pre-cooled mud condition.

A system of interpretation consisting of a combination of graphic and numerical studies was used to study the logs. From graphical studies, evidence of hydrothermal alteration may be established from the trend analysis of SP (self potentia1) and ILD (deep induction $10 \mathrm{~g}$ ). Furthermore, the cross plot techniques using data from density and neutron logs may help in establishing compaction as well as rock density profile with depth.

In the numerical method, $R_{\text {wa }}$ values from three different resistivity logs were computed and brought into agreement. From this approach we were able to establish values of formation temperature and mud filtrate resistivity effective at the time of logging.
\end{abstract}




\section{INTRODUCTION}

The estimation of reserve and calculation of recovery for a subterranean resource requires tools and techniques that either directly or indirectly measure properties of the resource. In the field of oil and gas technology, reservoir engineers rely heavily on borehole geophysical surveys. The first objective of such surveys is detecting the presence of hydrocarbon. Upon the discovery of hydrocarbon, attention is then focused on the lithological and structural characteristics of the reservoir rock.

Since well logs do not measure any of the important rock and fluid properties directly, accurate interpretation of $10 \mathrm{~g}$ derived values requires a good understanding of borehole conditions, lithology, and the physical limitations of the tools and their proper calibration.

Significant progress in all areas of well logging has been made during the last two decades. Improvements in tool design and calibration as well as advancement in the art of well $\mathrm{log}$ interpretation has made the well $\operatorname{logs}$ a basic ingredient in most field exploration and development prograns.

Petrophysical studies using electrical or radioactive well logs for oil and gas reservoirs have contributed significantly to an understanding of the configurations and geologic characteristics of such reservoirs. Some aspects of $10 \mathrm{~g}$ interpretation for oil and gas reservoirs, however, are still undeveloped and additional research work is. seriously needed. Examples include detection of fracture permeability, permeability profile, and high temperature environment effects on empirical correlations.

In recent years other subterranean energy resources such as geothermal, coal, and uranium have come into focus. A review of literature shows a surge in the application of existing techniques to nonpetroleum resources. As a result, the interest in advancement of the science and the art of subsurface formation evaluation is expanding in all directions.

Because of the differences in the type of energy resources and their environments, requirements on both the logging tools and the interpretation techniques may vary. Just as tools or techniques developed for oil and gas exploration may have application to other areas, advancements in the development of new methods for recording or analyzing data in nonpetroleum resources may contribute to the better evaluation of $o i l$ and gas formations under severe borehole conditions or for nonconventional lithologies. 
The purpose of this study was to apply the current state of the art of well log interpretation to logs available from a liquid-dominated geothermal system. Because of temperature limitations on tools and complex lithologies, in only very few cases have well logs been run in geothermal systems. For metamorphic and igneous rocks some of the conventional logs such as Induction Electric Survey (IES) lose their diagnostic capabilities. Since most of the oilfield type interpretation techniques include the use of SP and resistivity data, for the purpose of this research we focused on a geothermal reservoir with lithologies similar to oilfield systems.

The Cerro Prieto Field located in Mexico was selected for this purpose. The lithology is mostly a sand-shale series. The available logs are conventional surveys such as Induction-Electric Log, Dual-Induction Laterolog, Compensated Density Log, and Compensated Neutron Log. This field has become an international scientific laboratory for researchers and scientists studying different aspects of the geothermal resource.

Through a cooperative program between the Comision Federal de Electricidad de Mexico and the Lawrence Berkeley Laboratory (LBL) copies of certain well logs were made available. Unfortunately, there was not a complete suite of logs for most wells. We therefore implemented our study with a limited number of logs. This included a Compensated Formation Density, Gamma Ray, DualInduction Laterolog with Self-Potential, and Compensated Neutron Log.

Our first objective was to analyze the logs with total disregard for the lithological characteristics and the extreme temperature ranges of the formation. Second, we were to identify the limitation of the existing data base and point out the desired additional data needed for a complete evaluation job. Third, work was focused on analyzing the data to arrive at a feasible interpretation and to compare the results with reservoir data available from other published studies.

\section{GEOLOGY OF THE CERRO PRIETO FIELD}

The Cerro Prieto Geothermal Field is located in the Mexicali-Salton Sea basin about $35 \mathrm{~km}$ south of Mexicali in Baja California, Fig. I. The field is named after the nearby Cerro Prieto (Black Hill) volcano.

As described by Noble, et al. ${ }^{1}$ the reservoir at Cerro Prieto consists of an interbedded sequence of deltaic sands and shales of variable thicknesses. 


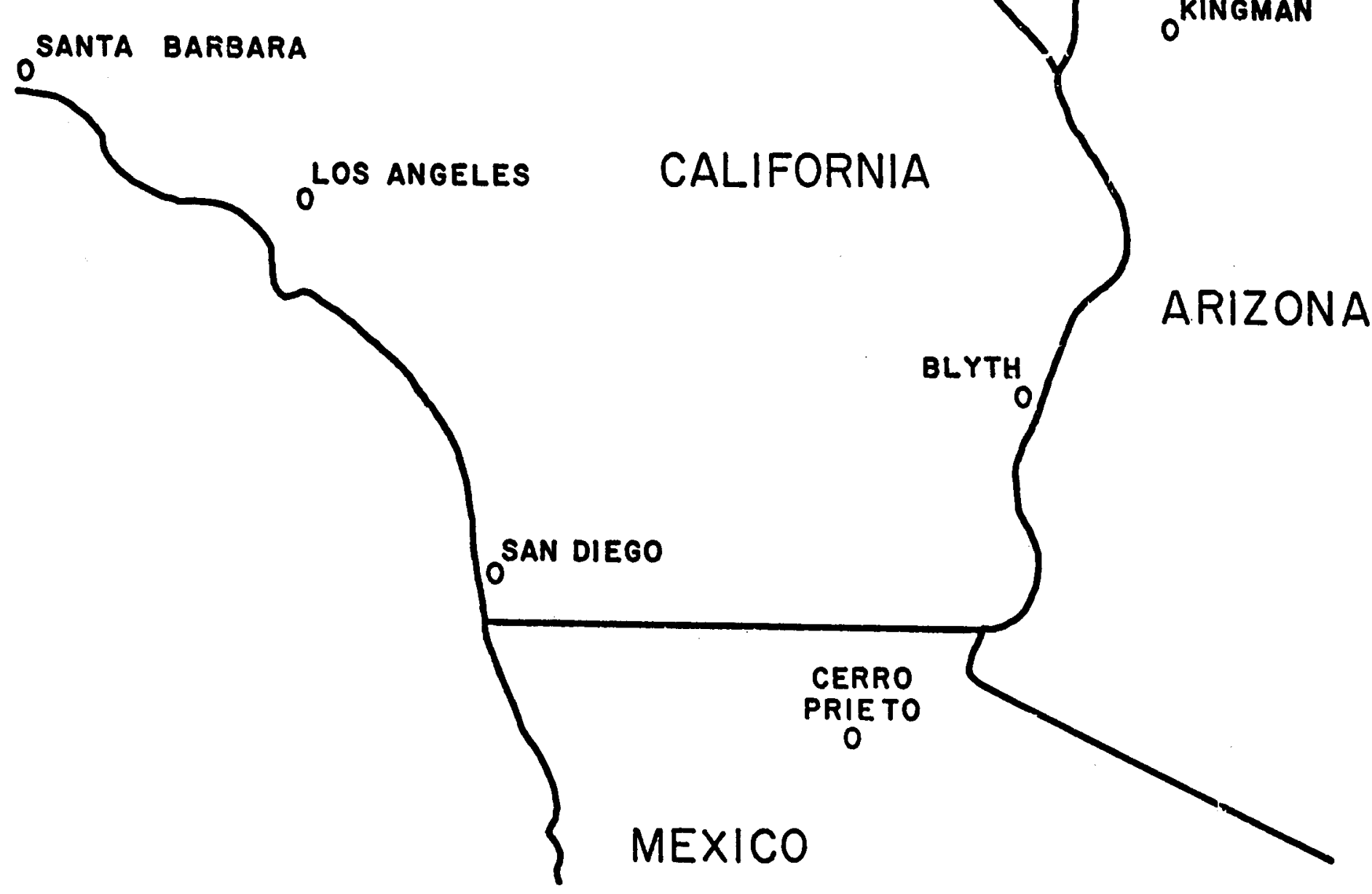

Fig. 1. Geographical location of the Cerro Prieto. Ficld. 
Cruz $^{2}$ indicated that the deltaic sediments may be divided into two units: unconsolidated Quaternary sediments composed of clays, sands and gravels, and consolidated tertiary deltaic sediments composed of siltstone, shales and sandstones.

Elders ${ }^{3}$ and his co-workers have done extensive work using $x$-ray diffraction on cuttings and cores to identify the mineralogic composition of reservoir rock in Cerro Prieto. Based on their results, ${ }^{4-6}$ indications are that the most abundant minerals in the sediments include quartz, feldspar, kaolinite, montmorillonite, illite, chlorite, mixed-layer clays, calcite, dolomite and iron hydroxides. Such a complex lithological composition is bound to create problems in well $\mathrm{log}$ interpretation when calibration data are scarce.

\section{DEVELOPMENT}

The exploration of Cerro Prieto was initiated in 1961 with the drilling of a number of wells to establish the feasibility of producing steam. The second phase of the exploration activities was undertaken in 1964 when two out of four wells drilled were producers (M-3 and $M-5)$. This success led to the next phase, the development of the field, and has continued up to the present.

As of the date of this study, a total of 55 wells have been drilled in the Cerro Prieto Field, of which 42 are producers. Most of the wells have been logged, although wellbore problems have precluded the implementation of a complete logging program.

According to the list published, ${ }^{7}$ a typical suite of logs for individual wells consists of Induction Electric Survey, Dual Induction Laterolog, Compensated Formation Density, Compensated Neutron Log and Saraband. No acoustic logs are listed in this inventory. Temperature logs have either not been run on most wells or the ones run were not made available to us except for two wells.

From the LBL inventory we acquired the logs listed in Table $I$. For the purpose of our study we were interested in the balloon or large scale version of the logs $(5$ inches $=100 \mathrm{ft}$.$) . The wells and the intervals marked with$ asterisks are the logs with the large scale which were analyzed in the study.

\section{OBJECTIVE OF THE STUDY}

This study was initiated to test the application of oilfield type well-log interpretation techniques to the Cerro Prieto Geothermal Field. The first task 
TABLE I

LIST OF THE LOGS RECEIVED FROM LBL

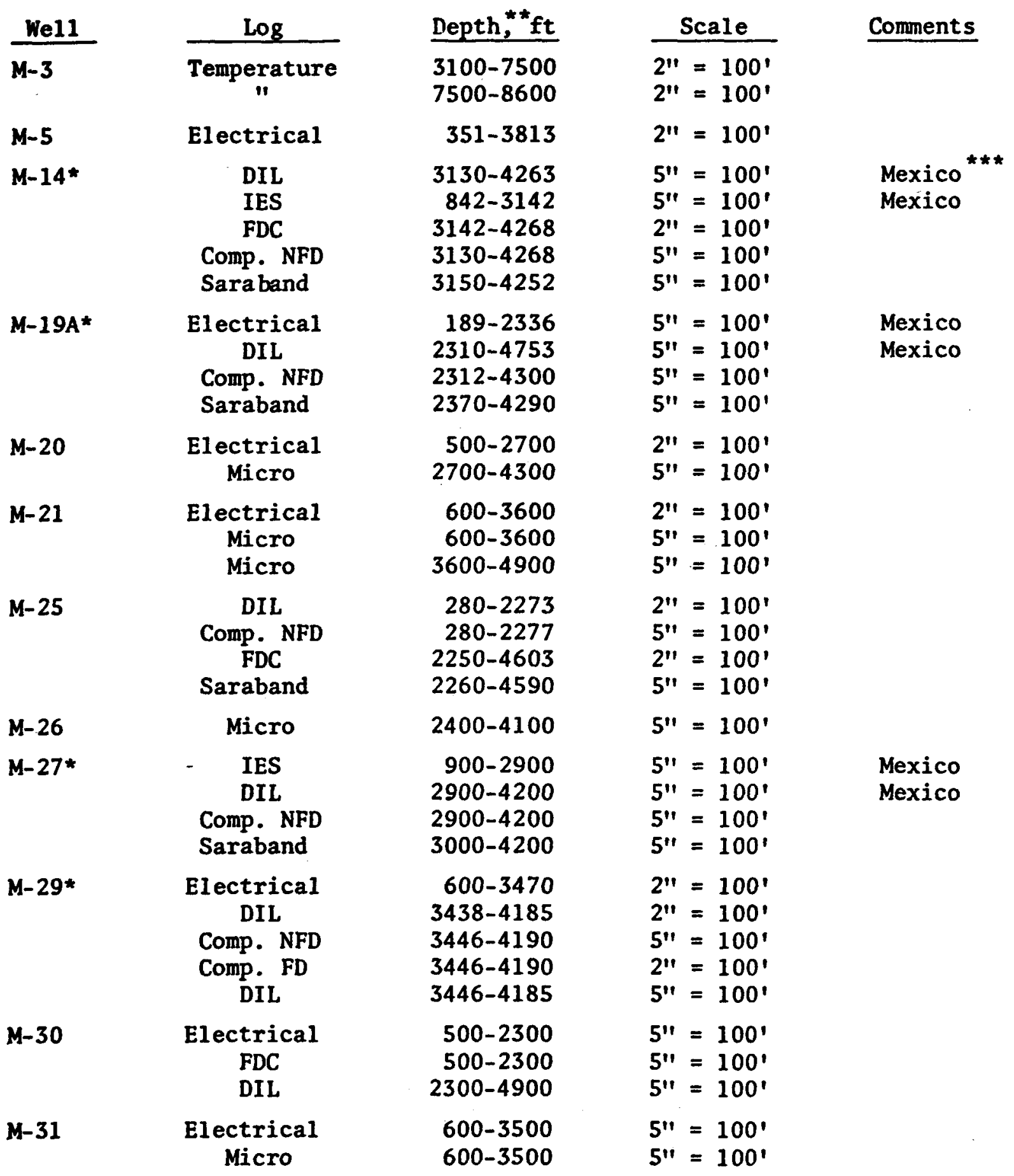


$\frac{\text { We11 }}{M-35}$

M-38

M-39

$M-42$ *

$M-45$ *

$M-46$

$M-51$

M-53

\begin{tabular}{l} 
Log \\
\hline DIL \\
Comp. CNL \\
FDC \\
Saraband \\
Saraband
\end{tabular}

Electrical "

Micro

Micro
Electrical
Micro

IES

Comp. NFD
Electrical
IES

Comp. NFD FDC

DIL

Saraband

IES

DIL

FDC

Electrical

DIL

Saraband

DIL

DIL

Saraband

$$
\begin{array}{r}
\text { Depth, ft } \\
\hline 500-2100 \\
500-2100 \\
500-2100 \\
600-2100 \\
2500-4500
\end{array}
$$

600-3600

$3600-4900$

600-3600

3600-4800

100-4916

600-4915

600-3600

2600-4300

2600-4300

600-2400

600-2400

2400-4600

2300-4600

2400-4600

2500-4500

644-2788

2770-4661

2770-4667

511-2315

2305-5248

2310-5240

762-3605

3601-6210

815-3590

$$
\begin{aligned}
& \text { Scale } \\
& 5^{\prime \prime}=100^{\prime} \\
& 5^{\prime \prime}=100^{\prime} \\
& 5^{\prime \prime}=100^{\prime} \\
& 5^{\prime \prime}=100^{\prime} \\
& 5^{\prime \prime}=100^{\prime} \\
& 5^{\prime \prime}=100^{\prime} \\
& 2^{\prime \prime}=100^{\prime} \\
& 5^{\prime \prime}=100^{\prime} \\
& 5^{\prime \prime}=100^{\prime} \\
& 2^{\prime \prime}=100^{\prime} \\
& 2^{\prime \prime}=100^{\prime} \\
& 5^{\prime \prime}=100^{\prime} \\
& 5^{\prime \prime}=100^{\prime} \\
& 5^{\prime \prime}=100^{\prime} \\
& 2^{\prime \prime}=100^{\prime} \\
& 5^{\prime \prime}=100^{\prime} \\
& 5^{\prime \prime}=100^{\prime} \\
& 5^{\prime \prime}=100^{\prime} \\
& 5^{\prime \prime}=100^{\prime} \\
& 5^{\prime \prime}=100^{\prime} \\
& 5^{\prime \prime}=100^{\prime} \\
& 5^{\prime \prime}=100^{\prime} \\
& 5^{\prime \prime}=100^{\prime} \\
& 59^{\prime}
\end{aligned}
$$

$5^{\prime \prime}=100^{\prime}$

$2^{\prime \prime}=100^{\prime}$

$5^{\prime \prime}=100^{\prime}$

$2^{\prime \prime}=100^{\prime}$

$2^{\prime \prime}=100^{\prime}$

$5^{\prime \prime}=100^{\prime}$

Mexico

Mexico

Mexico

\footnotetext{
*Wells analyzed here.

** Depth as recorded in $\mathrm{ft}$.

Logs obtained directly from Mexico.
} 
was to examine the quality of the $\log$ in view of the hostile conditions existing in the wellbore. Next, we interpreted the logs and derived certain rock and fluid properties. Finally, we compared the computed results with data available from other published studies.

The parameters of interest included formation rock porosity, shale content, reservoir temperature, and formation brine salinity.

In the course of this study we identified the deficiencies of available data and recommended improvements which should be incorporated in future borehole geophysical surveys. Also, we identified the major improvements necessary to upgrade existing correlations and equations.

\section{REVIEW OF EXISTING DATA}

Scientists and researchers, with varieties of backgrounds and interests, have studied the Cerro Prieto Geothermal Field. A review of published literature shows that the major studies fall into one of the following categories: geophysical, geochemical, geological, or reservoir engineering.

Very little has been published about the interpretation of geophysical logs although there is evidence that both Mexican and $\mathrm{U} S$ agencies have done various studies on such logs.

Required for our study and subsequent comparative analysis were certain data on core analysis, drilling, temperature, and fluid analysis.

Except for several geochemical studies, ${ }^{8}$ very little data about the rock properties have been published. Elders and his co-workers conducted a significant study on fragments of reservoir rock. ${ }^{6}$ This study clearly showed the hydrothermal alteration of deep rocks and a corresponding change in the mineralogy. But actual core analyses with reservoir rock porosity and permeability data are scarce.

Temperature log data reflect the unequilibrated condition in the borehole. However, from various reports and publications indications are that the deep formation temperatures may range from $204-315^{\circ} \mathrm{C}\left(400-600^{\circ} \mathrm{F}\right) .^{4,9}$

Copies of drilling summaries accompanied the well logs. The summaries for the cases analyzed in this report are included in Appendix $D$. Since the well logs under our study represent the early wells drilled in the area, information about the drilling mud composition and properties are sketchy. With the newer wells, a programmed mud composition is established in advance of drilling. 
VI. METHOD OF STUDY

The well logs were interpreted using a combination of graphic and numerical studies. Graphic studies were aimed at checking the quality of the logs, and analyzing the trend and certain overlays. Numerical studies included the digitization of logs, determination of certain rock and fluid properties through the use of a specially developed computer program and the use of various cross plots.

The numerical studies reported here include only four wells which had relatively complete suites of logs at the time of the study. The graphical studies were extended to other wells with partial well logs. Figure 2 shows the location of the four wells in the field.

A. Graphic Studies

The first task in the category was the quality check on the logs. The calibrations were checked by scrutinizing the repeat sections recorded on the bottom of the logs as well as by analyzing the errors associated with high and low calibration points and recorder offset error.

As shown in Appendix A, most logs in the series seem to be of acceptable quality. Unfortunately, the repeat sections were not available on all of the logs. Because of temperature effects on the tool and the recorded data, it is imperative that the repeat sections be included for all runs. The examination of the repeat sections can be very educational in understanding the behavior of measurement devices under adverse environments.

A very important lithology $\log$ in the analysis of sand-shale series is the Self-Potential log. A routine comparison of the Self-Potential log with corresponding Gamma-Ray log recorded with a Compensated Formation Density or Compensated Neutron Log may be extremely helpful in judging the quality of the Self-Potential log. Our graphical overlays of these two logs for most of the wells indicate that a high degree of reliability exists in the Self-Potential logs.

In only a few cases we have observed discrepancies between the Gamma Ray and the Self-Potential logs. Figure 3 shows an example of such a case for We11 M-25. While the Gamma Ray strongly suggests the presence of low radioactivity (sand), the Self-Potential log shows the existence of an impermeable formation. There are several possible reasons for this effect. First, these

${ }^{*} \mathrm{~A}$ listing of the computer program is available upon request. 


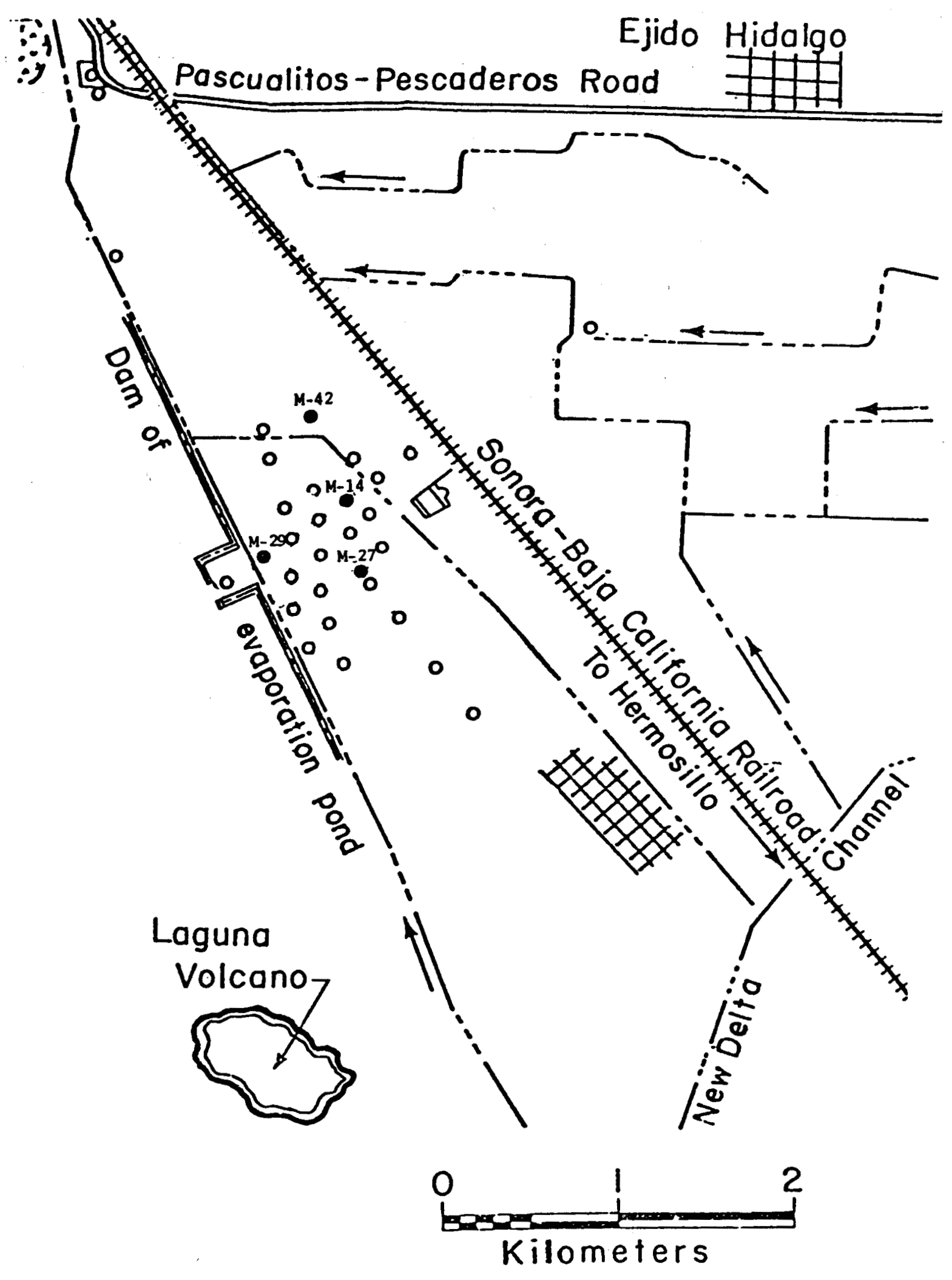

Fig. 2. Location of the 4 wells studied in this report. 
intervals could be impermeable layers such as anhydrite or carbonates. Such impermeable layers would cause extremely high resistivity readings on the deep induction log. Second, a change in salinity of water in the formation or in the mud, may cause the activity ratio $\left(\frac{a}{a f e}\right)$ to approach unity and may result in insignificant SP. (For a description of the activity ratio see the SelfPotential equation in Appendix C.) Since there is no evidence of unusually high values for the deep induction readings, there may have been a change in either the formation water resistivity or drilling mud composition. Such sections were not analyzed because of inadequate data about the drilling conditions and mud composition.

Another observation of significant importance is the gradual changes in the trend of deep induction $10 \mathrm{~g}$ with depth. In most wells, the deep induction $\log$ indicates increasing electrical resistivity or decreasing electrical conductivity with depth. Since increasing temperature with depth would result in increasing conductivity or decreasing resistivity, some other factor must be responsible for this effect. One possible explanation, supported by studies of the Self-Potential logs and further substantiated by Elder's data, is the gradual phasing out of the shale's contribution to the overall rock conductivity. Hydrothermal alteration of rocks and exposure of clays to extreme temperature will essentially make them inactive in terms of electrical conductivity. This observation on the induction $\log$ can be of considerable importance in correlating the wells for establishing the starting depth of hydrothermal alteration. Figure 4 shows a sample log depicting the above condition for Well M-19A. B. Numerical Studies

The usual approach to well $\mathrm{log}$ interpretation consists of collection of the raw data, selection of the suitable equations, and through the use of manual or computerized techniques, conversion of the raw data into basic rock and fluid properties. At this point, the experience in well $\log$ interpretation and a familiarity with the given field, influence the final interpretation. The more experience, the more reliable should be the final outcome.

We recognize that complex lithology presents a problem for this study. The problem is perhaps more severe here because of the possible existence of nongranular (fracture) porosity and permeability.

Because of inadequate data, a new approach was devised to study the well logs. Resistivity of the formation brine $\left(R_{w}\right)$ was selected as the control 


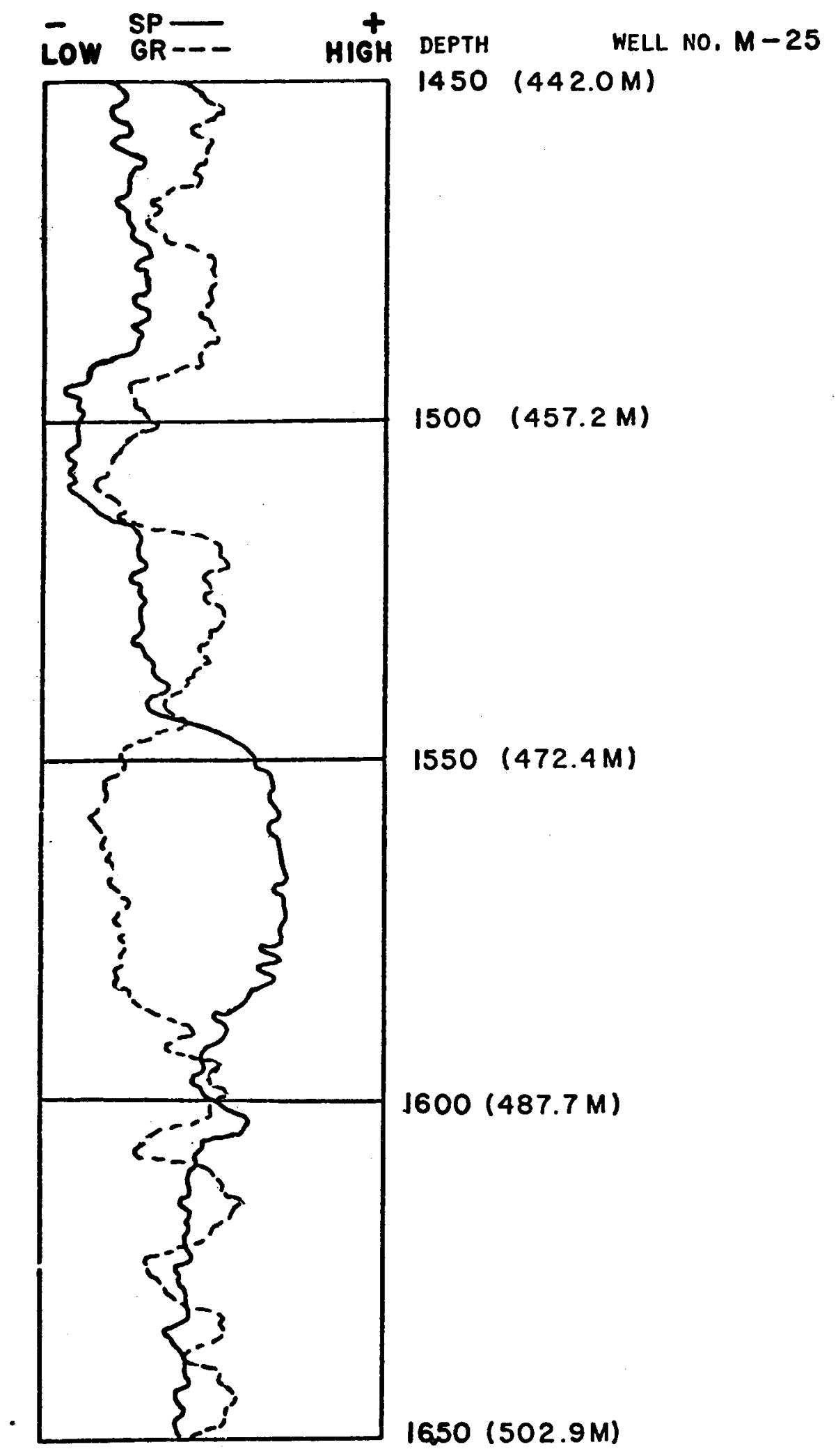

Fig. 3. SP-Gamma Ray Overlay for Well M-25. 


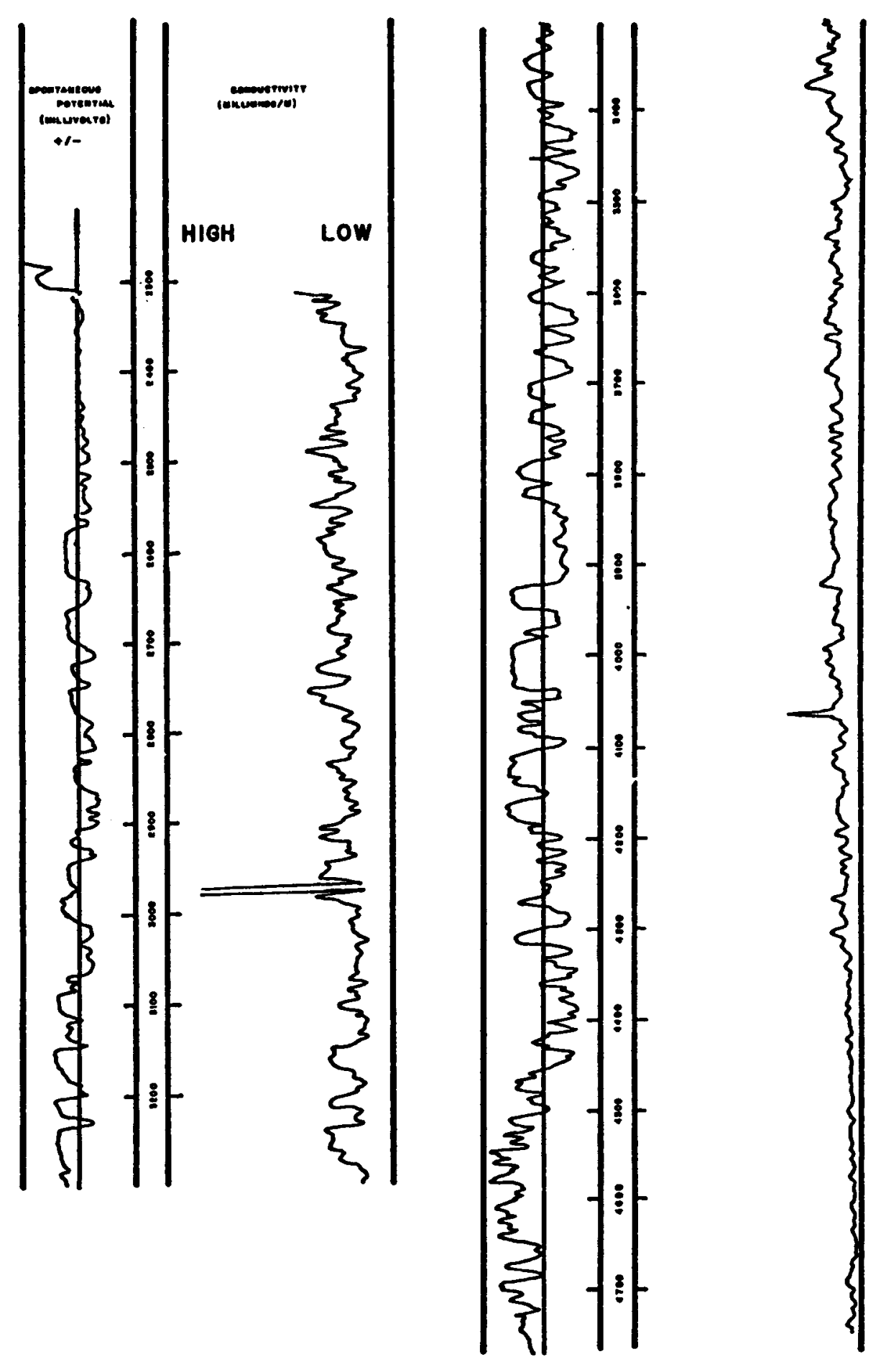

Fig. 4. Induction-Electric Log for Well M-19. 
parameter. With adequate data, apparent $R_{w}\left(R_{w a}\right)$ computed from Self-Potential, invaded zone resistivity $\left(R_{x o}\right)$, and deep formation resistivity $\left(R_{t}\right)$ should be identical. Equations relating $R_{\text {wa }}$ to $l 0 g$ derived values from the three approaches cited above, however, include other input parameters about the formation lithology, drilling fluid properties, and temperature profile. We used a trial and error technique to arrive at these unknown parameters. Since in most cases the problem may have multiple solutions, the optimum answers were selected in accordance with other known and published data about the field.

Appendix B shows a summary of all equations used in the computations. In brief, from the Dual-Induction Laterolog data, $R_{t}, R_{x o}$ and $D_{i}$ were computed, then:

$$
F_{x o}=\frac{R_{x o}}{R_{m f f}},
$$

where $R_{m f f}$ is the $R_{m f}$ (resistivity of mud filtrate) at formation temperature. From this estimation of $F_{x o}$ and the $R_{t}$ data, an estimate of $R_{\text {wa }}$ may be obtained, which in this report is referred to as $R_{\text {wax }}$. Also from the Self-Potential data, an estimate of $R_{w a}$ may be obtained which is called here $R_{w s p}$. The cross plot of $\phi_{D}$ vs $\phi_{N}$ provides estimates of VSH (fraction of shale content), and effective and total porosity. Using the equation for shaly sand, an estimate of $R_{\text {wa }}$ may be obtained from the $R_{t}$ data incorporating the contribution of the surface conductivity by clay material.

To obtain an acceptable match between $R_{\text {wsp }}$ and $R_{\text {wax }}$, an optimum $R_{\operatorname{mf}}$ is determined from the following quadratic equation.

$$
A R_{m f}^{2}+B R_{m f}+C=0 \text {, }
$$

where

$$
\begin{aligned}
& A=286.45 \frac{R_{t}}{R_{x o} \text { Ratio }} \\
& B=146 \frac{R_{t}}{R_{x 0}}-\frac{65.45}{\text { Ratio }} \\
& C=-5 \\
& \text { Ratio }=10^{-S P /(60+.133 T)}
\end{aligned}
$$


The above equation may be derived by equating $R_{w s p}$ and $R_{\text {wax }}$ from their corresponding relationships:

$$
R_{w s p}=\frac{77 \frac{R_{m f e}}{\text { Ratio }}+5}{146-337 \frac{R_{m f e}}{\text { Ratio }}},
$$

where

$$
\begin{aligned}
& R_{m f e}=0.85 R_{m f}, \\
& R_{\text {wax }}=\frac{R_{t}}{R_{x 0}} R_{m f} .
\end{aligned}
$$

Upon determination of the optimum $R_{m f}$ at a given $T$, attention was focused on $R_{\text {wad }}$ calculation:

$$
R_{w a d}=\frac{\phi_{e}}{\phi_{t}\left[\frac{F}{R_{t}}-\frac{\phi_{t}-\phi_{e}}{\phi_{t}} \frac{1}{R_{w c 1 y}}\right]} \text {. }
$$

Equation (10) considers the contribution of clay to the overall conductivity. ${ }^{11}$ Both $\phi_{D}$ and $\phi_{t}$ are functions of $\phi_{\mathrm{NC}}, \phi_{\mathrm{DC}}, \rho_{\mathrm{WC}}, \rho_{\mathrm{DC}}$. Parameters a and $\mathrm{m}$ also enter into the equation for $F$.

1. The Simulation Program. A computer program was developed to perform the computations for a given interval and for a set of assumed parameters. The general structure of the program is illustrated in the flow diagram of Appendix B.

Under option 1 mode, the purpose is to read the basic $10 g$ derived values and print cross plots of $\phi_{D} v s \phi_{N}$. From the cross plot, the values of $\phi_{D C}$, $\rho_{\mathrm{NC}}$, and $\rho_{\mathrm{WC}}$ may be obtained by graphical construction as discussed by Krug and Cox. ${ }^{10}$ The program is then run under option 2 mode where assumed values of $a, m, T$, and $R_{\text {wcly }}$ are used. By switching ITCOD $=1$, the program will use the temperature data based on the bottom hole temperature recorded on the logs. If higher temperatures are employed, the ITCOD is set at 2 .

The computation includes the determination of $R_{t}, R_{w s p}, R_{w a x}, \phi_{e}, \phi_{t}$, VSH, $R_{\text {wad }}$ and $S_{w^{*}}$ During the first trial runs, the emphasis is on closing the gap between $R_{\text {wsp }}$ and $R_{\text {wax }}$. This is mainly controlled by adjustment of $T$ and $R_{m f}$ 
data. For a given $T$, using the method described earlier, the program prints $R_{m f x}$. This, according to the program, is the optimum $R_{m f}$ at the given reservoir temperature that would result in exact identity between $R_{w s p}$ and $R_{\text {wax }}$. An avorage of these values converted to the surface temperature is used in subsequent runs.

Once reasonable agreement between $R_{\text {wsp }}$ and $R_{\text {wax }}$ is reached, the emphasis is then focused on $R_{w a d}$. The process here is somewhat more complicated because there are a number of parameters that could be varied. This includes basic shale properties as determined from the cross plots of $\phi_{D}$ vs $\phi_{N}$, a and $m$.

2. Estimation of Formation Water Salinity. Formation water resistivities as computed from three different techniques may be converted to equivalent $\mathrm{NaCl}$ concentration. The following equation based on published data in most well logging handbooks was derived and used in the computation of equivalent $\mathrm{NaCl}$ concentration:

$$
\text { SALLY }=e^{\left(8.6045-1.06156 \log \left(R_{W}\right)+.0188\left(\log R_{W}\right)^{2}\right)},
$$

where $R_{w}$ is the water resistivity at $23.9^{\circ} \mathrm{C}\left(75^{\circ} \mathrm{F}\right)$ and SALLY is the equivalent $\mathrm{NaCl}$ salinity in ppm.

To convert the $R_{W}$ at formation temperature to $R_{W}$ at $23.9^{\circ} \mathrm{C}\left(75^{\circ} \mathrm{F}\right)$, we used the $\operatorname{Arps}^{12}$ approximation formula:

$$
R_{w 75}=R_{w} T_{f} \frac{T_{f}+7}{82} \text {. }
$$

Recently published laboratory data, ${ }^{13}$ however, indicate that the above equation may cause erroneous results when applied for temperatures above $260^{\circ} \mathrm{C}$ $\left(500^{\circ} \mathrm{F}\right)$. The use of the Arps equation in our computation was justified because for cases studied, temperatures less than $260^{\circ} \mathrm{C}\left(500^{\circ} \mathrm{F}\right)$ were assumed.

Computation of salinity enabled us to amplify the variation in $R_{w}$ and get a better match from the three techniques. As mentioned earlier, the computed salinities represent the equivalent $\mathrm{NaCl}$ concentration. The actual salinities may be lower or higher depending on the type of the brine composition. 
3. Temperature Profile. During the logging operation, estimation of temperature in the borehole and the temperature profile into the formation is of utmost necessity. The conventional approach of recording bottomhole temperature is not adequate for accurate interpretation of resistivity logs. The borehole temperature at any given point follows a logarithmic function of time and eventually should approach the deep formation temperature. ${ }^{14}$ Meanwhile, the temperature profile between the extremes, that is, the borehole and the deep formation is continuously changing. This change would influence the resistivity $10 \mathrm{~g}$ readings depending on the depth of investigation of the tool.

For most of the Cerro Prieto wells under our study, the deep formation temperature has been reported to range from $204^{\circ} \mathrm{C}$ to $315^{\circ} \mathrm{C}\left(400-600^{\circ} \mathrm{F}\right)$. At the same time, the recorded bottomhole temperatures (because of downhole cooling of the mud) are generally lower than $121^{\circ} \mathrm{C}\left(250^{\circ} \mathrm{F}\right)$.

In the absence of accurate temperature data, one may assume values and by trial-and-error establish the validity of such assumptions.

\section{RESULTS OF NUMERICAL STUDIES}

A total of four wells have been analyzed and reported here. This included $M-14, M-27, M-29$, and $M-42$. We had access to the Dual Induction Laterolog, Formation Density Compensated, Compensated Neutron Log, and Saraband logs for these wells. In general, the Self-Potential log conforms to the Gama Ray log and the invasion diameter seems sufficient to justify the application of the proposed method.

A copy of the drilling report summaries and computer printouts for these wells is included in Appendix D. To minimize the bulkiness of the report, for each well a few permeable sections were selected representing shallow, medium and deep intervals.

A summary of trial runs on Well 14 is shown in Table II. Two sections of the well have been analyzed here. The shallow sand is located in the depth range of 1017-1031 $\mathrm{m}$ (3338-3384 ft.) and the deep sand is at 1099-1113 $\mathrm{m}$ (3606$\left.3652 \mathrm{ft}_{.}\right)$. Using the $\mathrm{R}_{\mathrm{mf}}$ data as indicated on the $\log$ heading $(1.34 \mathrm{ohm}-\mathrm{m}$ at $21.6^{\circ} \mathrm{C}\left(71^{\circ} \mathrm{F}\right)$ ) and applying a temperature based on recorded BHT (bottomhole temperature) during logging $\left(T=107^{\circ} \mathrm{C}\right.$ or $\left.225^{\circ} \mathrm{F}\right)$, the average $\mathrm{R}_{\text {wax }}$ differs significantly from the $\mathrm{R}_{w s p}$ and $\mathrm{R}_{\text {wad }}$. Increasing the temperature to $260^{\circ} \mathrm{C}$ $\left(500^{\circ} \mathrm{F}\right)$ improves the match somewhat. Since there is an upper limit one could 
assign to reservoir temperature, the next alternative is to use $R_{m f x}$ values as computed by the program. When corrected to a surface temperature of $21.6^{\circ} \mathrm{C}$ $\left(71^{\circ} \mathrm{F}\right.$ ) a value of $R_{m f}=0.37 \mathrm{ohm}-m$ is obtained. Using this new value of $R_{m f}$, the $R_{w}$ match improves substantially as shown in Table 14-3 and plotted in Fig. 14-3. Reducing the $R_{m f}$ to $0.344 \mathrm{ohm}-\pi_{1}$ at $23.9^{\circ} \mathrm{C}\left(75^{\circ} \mathrm{F}\right.$ ) would allow a reduction of the assumed value for reservoir temperature to $232.2^{\circ} \mathrm{C}\left(450^{\circ} \mathrm{F}\right)$ and still maintain a good match (See Table 14-4 and Fig. 14-4). Similar results are evident for the deep sand 1099-1113 $\mathrm{m}$ (36-6-3652 ft.). The general conclusion at this point is that the $R_{m f}$ values reported on the $10 g$ heading are not representative of actual bottomhole mud composition. A possible cause for this discrepancy is the heterogeneous nature of the mud column. According to the drilling report, the mud column had been cooled down by using ice to ease the logging operation.

As shown for Wel1 14 and other wells, the use of low temperatures results in great discrepancies among the computed $R_{\text {wa }}$ 's. For example, in Table III for We11 27, the change of temperature from $94.4^{\circ} \mathrm{C}\left(202^{\circ} \mathrm{F}\right)$ to an estimated $232.2^{\circ} \mathrm{C}$ $\left(450^{\circ} \mathrm{F}\right.$ ) improves the match between the three $R_{\text {wa }}$ 's significantly (compare run 27-1 with 27-5 and 27-8 with 27-9).

Generally the optimum temperatures seem to be much higher than the wellbore temperature and lower than the deep reservoir temperature indicating a slight cooling in the immediate vicinity of the wellbore.

Another controlling factor in achieving a match is the value for exponent m (cementation factor). A quick glance at the Tables II through IV indicates that we have used $m=2.3$ in most cases. This is an estimate obtained after many trial runs. The sensitivity of computations with respect to the estimated value of $\mathrm{m}$ is shown for a few cases. Notice $\mathrm{R}_{\text {wad }}$ increases in the interval of 927-939 $\mathrm{m}(3042-3080 \mathrm{ft}$.) for Well 42 when only $\mathrm{m}$ is reduced and other parameters remain unchanged.

A major consideration in the selection of the appropriate parameters is the examination of computed $S_{w} \cdot$ By and large, $S_{w}$ values above unity are unacceptable. In cases where an optimum match between the three $\mathrm{R}_{w a}, \mathrm{~s}$ has been obtained, we have observed $S_{w}$ values of one or less. Ordinarily, for a liquid dominated system, one expects the formation to be saturated one hundred percent with liquid. However, the presence of free gases such as $\mathrm{CO}_{2}, \mathrm{~N}_{2}$, and $\mathrm{CH}_{4}$ in the system may result in computed $S_{w}$ values less than unity. 
TABLE 11

SUMMARY OF COMPUTED RESULTS WELL M-14

\begin{tabular}{|c|c|c|c|c|c|c|c|c|c|c|c|}
\hline \multirow[b]{2}{*}{ Interval $m(f t)$} & \multicolumn{4}{|c|}{$\phi_{\mathrm{DC}}=0.01$} & \multicolumn{5}{|c|}{$\rho_{D C}=2.8 \mathrm{gm} / \mathrm{cc} \quad \rho_{W C}=2.62 \mathrm{gm} / \mathrm{cc}$} & \multirow[b]{2}{*}{$\begin{array}{l}\text { Avg. } R_{\text {WAD }} \\
\text { (ohm-m) }\end{array}$} & \multirow[b]{2}{*}{$\begin{array}{c}\text { (Appendix D) } \\
\text { Table No. } \\
\end{array}$} \\
\hline & $\begin{array}{c}R_{m f} \\
(o h m-m) \\
\end{array}$ & 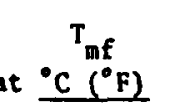 & ${ }^{\circ} \mathrm{C}\left({ }^{\mathrm{T}}{ }^{\mathrm{o}} \mathrm{F}\right)$ & a & $\underline{m}$ & $\begin{array}{l}R_{w c l y} \\
\text { (ohm-m) } \\
\end{array}$ & $\begin{array}{c}R_{s h "}^{*} \\
(\text { (ohm-m) }\end{array}$ & $\begin{array}{c}\text { Avg. R RSP } \\
(0 \mathrm{hm}-\mathrm{m})\end{array}$ & $\begin{array}{l}\text { Avg } \cdot R_{\text {WAX }} \\
\text { (ohm-m) }\end{array}$ & & \\
\hline $\begin{array}{c}1017-1031 \\
(3338-3384)\end{array}$ & 1.34 & $21.6(71)$ & $107(225)$ & 1 & 2.3 & 0.1 & 1.5 & 0.07 & 0.35 & 0.05 & $14-1$ \\
\hline $1017-1031$ & 1.34 & $21.6(71)$ & $260(500)$ & 1 & 2.3 & 0.1 & 1.5 & 0.065 & 0.16 & 0.05 & $14-2$ \\
\hline $1017-1031$ & 0.37 & $23.9(75)$ & $260(500)$ & 1 & 2.3 & 0.1 & 1.5 & 0.04 & 0.05 & 0.05 & $14-3$ \\
\hline $1017-1031$ & 0.334 & $23.9(75)$ & $232.2(450)$ & 1 & 2.3 & 0.1 & 1.5 & 0.04 & 0.045 & 0.05 & $14-4$ \\
\hline $\begin{array}{c}1099-1113 \\
(3606-3652)\end{array}$ & 1.34 & $21.6(71)$ & $260(500)$ & 1 & 2.3 & 0.1 & 1.5 & 0.06 & 0.15 & 0.05 & $14-5$ \\
\hline $1099-1113$ & 1.34 & $21.6(71)$ & $232.2(450)$ & 1 & 2.3 & 0.1 & 1.5 & 0.06 & 0.18 & 0.05 & $14-6$ \\
\hline $1099-1113$ & 0.37 & $23.9(75)$ & $260(500)$ & 1 & 2.3 & 0.1 & 1.5 & 0.04 & 0.05 & 0.05 & $14-7$ \\
\hline $1099-1113$ & 0.334 & $23.9(75)$ & $232.2(450)$ & 1 & 2.3 & 0.1 & 1.5 & 0.04 & 0.05 & 0.05 & $14-8$ \\
\hline
\end{tabular}

At formation temperature 
TABLE III

SUMALARY OF COMPUTED RESULTS WELL M-27

\begin{tabular}{|c|c|c|c|c|c|c|c|c|c|c|c|}
\hline \multirow[b]{2}{*}{ Interval $m(f t)$} & \multirow[b]{2}{*}{$\begin{array}{c}\begin{array}{c}R_{\text {mf }} \\
\text { (ohm-m) at }\end{array} \\
\end{array}$} & $\Phi_{D C}=0.04$ & \multicolumn{2}{|c|}{$\phi_{N C}=0.29$} & \multicolumn{3}{|c|}{$\rho_{D C}=2.8 \mathrm{gm} / \mathrm{cc}$} & \multicolumn{2}{|c|}{$\sigma_{w C}=2.544 \mathrm{gm} / \mathrm{cc}$} & \multirow[b]{2}{*}{$\begin{array}{c}\text { Avg. R } \\
\text { (ohn-m) } \\
\end{array}$} & \multirow[b]{2}{*}{$\begin{array}{c}\text { (Appendix D) } \\
\text { Table No. }\end{array}$} \\
\hline & & $\begin{array}{c}T_{\mathrm{mf}} \\
{ }^{\circ} \mathrm{C}^{\bullet}\left({ }^{\bullet} \mathrm{F}\right) \\
\end{array}$ & $\begin{array}{c}T_{f} \\
{ }^{\circ} \mathrm{C}\left({ }^{\circ} F\right) \\
\end{array}$ & $\mathbf{a}$ & $m$ & $\begin{array}{c}R_{w c l y} \\
\text { (ohm-m) }\end{array}$ & $\begin{array}{c}R_{\text {sh }} \\
\text { (ohm-m) }\end{array}$ & $\begin{array}{c}\text { Avg. R } \\
\text { (ohm-m) } \\
\end{array}$ & $\begin{array}{l}\text { Avg. } R_{\text {wAX }} \\
\text { (ohm-m) }\end{array}$ & & \\
\hline $\begin{array}{c}923-934 \\
(3030-3064)\end{array}$ & 0.5 & $23.9(75)$ & $94.4(202)$ & 1 & 2.3 & 0.1 & 1.5 & 0.06 & 0.16 & 0.06 & $27-1$ \\
\hline 923-934 & 0.3 & $23.9(75)$ & $232.2(450)$ & 1 & 2.3 & 0.1 & 1.5 & 0.04 & 0.04 & 0.06 & $27-2$ \\
\hline $923-934$ & 0.3 & $23.9(75)$ & $232.2(450)$ & 1 & 2.0 & 0.1 & 1.5 & 0.04 & 0.04 & 0.09 & $27-3$ \\
\hline $923-934$ & 0.3 & $23.9(75)$ & $232.2(450)$ & 1 & 2.5 & 0.1 & 1.5 & 0.04 & 0.04 & 0.05 & $27-4$ \\
\hline 923-934 & 0.5 & $23.9(75)$ & $232.2(450)$ & 1 & 2.3 & 0.1 & 1.5 & 0.05 & 0.07 & 0.06 & $27-5$ \\
\hline $923-934$ & 0.5 & $23.9(75)$ & $232.2(450)$ & 1 & 2.5 & 0.1 & 1.5 & 0.05 & 0.07 & 0.05 & $27-6$ \\
\hline $923-934$ & 0.5 & $23.9(75)$ & $232.2(450)$ & 1 & 2.0 & 0.1 & 1.5 & 0.05 & 0.07 & 0.08 & $27-7$ \\
\hline $\begin{array}{c}1106-1122 \\
(3630-3680)\end{array}$ & 0.5 & $23.9(75)$ & $134.4(274)$ & 1 & 2.3 & 0.1 & 1.5 & 0.05 & 0.14 & 0.06 & $27-8$ \\
\hline $1106-1122$ & 0.5 & $23.9(75)$ & $232.2(450)$ & 1 & 2.3 & 0.1 & 1.5 & 0.05 & 0.09 & 0.06 & $27-9$ \\
\hline $1106-1122$ & 0.5 & $23.9(75)$ & $260(500)$ & 1 & 2.3 & 0.1 & 1.5 & 0.05 & 0.08 & 0.06 & $27-10$ \\
\hline $1106-1122$ & 0.5 & $23.9(75)$ & $260(500)$ & 1 & 2.5 & 0.1 & 1.5 & 0.05 & 0.07 & 0.05 & $27-11$ \\
\hline $\begin{array}{c}1272-1278 \\
(4174-4194)\end{array}$ & 0.5 & $23.9(75)$ & $170(338)$ & 1 & 2.3 & 0.1 & 4 & 0.05 & 0.09 & 0.06 & $27-12$ \\
\hline $1272-1278$ & 0.5 & $23.9(75)$ & $232.2(450)$ & 1 & 2.3 & 0.1 & 4 & 0.05 & 0.07 & 0.06 & $27-13$ \\
\hline $1272-1278$ & 0.5 & $23.9(75)$ & $232.2(450)$ & 1 & 2.0 & 0.1 & 4 & 0.05 & 0.06 & 0.07 & $27-14$ \\
\hline
\end{tabular}

^At-formetion temperature 
TABLE IV

SIMMARY OF COMPUTED RESULTS WELL M-29

\begin{tabular}{|c|c|c|c|c|c|c|c|c|c|c|c|}
\hline \multirow[b]{2}{*}{ Interval $m(f t)$} & \multirow[b]{2}{*}{$\begin{array}{c}R_{m f} \\
(o h m-m)\end{array}$ at } & \multirow{2}{*}{$\begin{array}{l}\phi_{D C}=0.05 \\
{ }^{T}{ }_{\operatorname{mf}} \\
{ }^{\circ}\left(^{\circ} \mathrm{F}\right)\end{array}$} & \multicolumn{2}{|c|}{$\phi_{\mathrm{NC}}=0.35$} & \multicolumn{3}{|c|}{$\rho_{D C}=2.8 \mathrm{gm} / \mathrm{cc}$} & \multicolumn{2}{|c|}{$\rho_{W C}=2.5175 \mathrm{gm} / \mathrm{cc}$} & \multirow[b]{2}{*}{$\begin{array}{l}\text { Avg. R RAD } \\
\text { (ohm-m) }\end{array}$} & \multirow[b]{2}{*}{$\begin{array}{c}\text { (Appendix D) } \\
\text { Table No. }\end{array}$} \\
\hline & & & $\begin{array}{c}T_{f} \\
{ }^{\circ} \mathrm{C}\left({ }^{\circ} F\right) \\
\end{array}$ & $\mathbf{a}$ & $m$ & $\begin{array}{r}R_{\text {wely }} \\
\text { (olum-m) }\end{array}$ & $\begin{array}{c}\left.R_{s h}{ }_{(0 l i m}-m\right) \\
\end{array}$ & $\begin{array}{l}\text { Avg. R RSP } \\
\text { (ohm-m) }\end{array}$ & $\begin{array}{l}\text { Avg. } R_{\text {waX }} \\
\text { (ohm-m) }\end{array}$ & & \\
\hline $\begin{array}{c}1059-1068 \\
(3476-3504)\end{array}$ & 0.3 & $23.9(75)$ & $96.1(205)$ & 1 & 2.3 & 0.1 & 1.6 & 0.050 & 0.06 & 0.04 & $29-1$ \\
\hline $1059-1068$ & 0.3 & $23.9(75)$ & $176.6(350)$ & 1 & 2.3 & 0.1 & 1.6 & 0.045 & 0.04 & 0.04 & $29-2$ \\
\hline $1059-1068$ & 0.3 & $23.9(75)$ & $232.2(450)$ & 1 & 2.3 & 0.1 & 1.6 & 0.04 & 0.03 & 0.04 & $29-3$ \\
\hline $1059-1068$ & 0.3 & $23.9(75)$ & $287.7(550)$ & 1 & 2.3 & 0.1 & 1.6 & 0.04 & 0.025 & 0.04 & $29-4$ \\
\hline $\begin{array}{c}1147-1157 \\
(3764-3798)\end{array}$ & 0.3 & $23.9(75)$ & $116.6(242)$ & 1 & 2.3 & 0.1 & 1.6 & 0.05 & 0.04 & 0.05 & $29-5$ \\
\hline $1147-1157$ & 0.3 & $23.9(75)$ & $204.4(400)$ & 1 & 2.3 & 0.1 & 1.6 & 0.05 & 0.02 & 0.05 & $29-6$ \\
\hline $\begin{array}{c}1204-1217 \\
(3952-3994)\end{array}$ & 0.3 & $23.9(75)$ & $129.4(265)$ & 1 & 2.3 & 0.1 & 1.6 & 0.05 & 0.035 & 0.055 & $29-7$ \\
\hline $1204-1217$ & 0.3 & $23.9(75)$ & $204.4(400)$ & 1 & 2.3 & 0.1 & 1.6 & 0.04 & 0.025 & 0.05 & $29-8$ \\
\hline $1204-1217$ & 0.5 & $23.9(75)$ & $204.4(400)$ & 1 & 2.3 & 0.1 & 1.6 & 0.05 & 0.045 & 0.06 & $29-9$ \\
\hline $1204-1217$ & 0.5 & $23.9(75)$ & $129.4(265)$ & 1 & 2.3 & 0.1 & 1.6 & 0.05 & 0.06 & 0.06 & $29-10$ \\
\hline $\begin{array}{c}1240-1248 \\
(4070-4096)\end{array}$ & 0.3 & $23.9(75)$ & $138.9(282)$ & 1 & 2.3 & 0.1 & 1.6 & 0.05 & 0.04 & 0.055 & $29-11$ \\
\hline $1240-1248$ & 0.3 & $23.9(75)$ & $204.4(400)$ & 1 & 2.3 & 0.1 & 1.6 & 0.04 & 0.035 & 0.055 & $29-12$ \\
\hline $1240-1248$ & 0.5 & $23.9(75)$ & $204.4(400)$ & 1 & 2.3 & 0.1 & 1.6 & 0.05 & 0.05 & 0.055 & $29-13$ \\
\hline
\end{tabular}

At formation temperature 
TABLE V

SUMMARY OF COMPUTED RESULTS WELL M-42

\begin{tabular}{|c|c|c|c|c|c|c|c|c|c|c|c|}
\hline \multirow[b]{2}{*}{ Interval $m(f t)$} & \multirow[b]{2}{*}{$\begin{array}{c}R_{m f} \\
(0 h m-m)\end{array}$} & \multicolumn{2}{|c|}{$\phi_{D C}=0.07$} & 0.36 & \multicolumn{3}{|c|}{$\rho_{D C}=2.8 \mathrm{gm} / \mathrm{cc}$} & \multicolumn{2}{|c|}{$p_{W C}=2.465 \mathrm{gm} / \mathrm{cc}$} & \multirow[b]{2}{*}{$\begin{array}{c}\text { Avg. } R_{\text {WAD }} \\
\text { (ohm-m) } \\
\end{array}$} & \multirow[b]{2}{*}{$\begin{array}{c}\text { (Appendix D) } \\
\text { Table No. }\end{array}$} \\
\hline & & $\begin{array}{c}T_{\operatorname{mf}} \\
{ }^{\circ} \mathrm{C}\left({ }^{\circ} \mathrm{F}\right) \\
\end{array}$ & ${ }^{\circ} \mathrm{C}\left({ }^{\circ} \mathrm{F}\right)$ & $\mathbf{8}$ & $\mathbf{m}$ & $\begin{array}{l}R_{\text {wely }}{ }^{*} \\
(\mathrm{ohm}-\mathrm{m}) \\
\end{array}$ & $\begin{array}{c}R_{s h}{ }^{*} \\
(\text { ohm-m) }\end{array}$ & $\begin{array}{l}\text { Avg. R } \text { WSP }^{*} \\
\text { (ohm-m) }\end{array}$ & $\begin{array}{l}\text { Avg. } R_{\text {WAX }} \\
(\text { ohm }-m) \\
\end{array}$ & & \\
\hline $\begin{array}{c}815-825 \\
(2674-2708)\end{array}$ & 0.3 & $23.9(75)$ & $73.8(165)$ & 1 & 2.3 & 0.1 & 1.0 & 0.05 & 0.08 & 0.05 & $42-1$ \\
\hline $815-825$ & 0.3 & $23.9(75)$ & $204.4(400)$ & 1 & 2.3 & 0.1 & 1.0 & 0.04 & 0.04 & 0.05 & $42-2$ \\
\hline $815-825$ & 0.3 & $23.9(75)$ & $204.4(400)$ & 1 & 2.4 & 0.1 & 1.0 & 0.04 & 0.04 & 0.05 & $42-3$ \\
\hline $\begin{array}{c}927-939 \\
(3042-3080)\end{array}$ & 0.3 & $23.9(75)$ & $204.4(400)$ & 1 & 2.3 & 0.1 & 1.0 & 0.04 & 0.03 & 0.035 & $42-4$ \\
\hline $927-939$ & 0.3 & $23.9(75)$ & $204.4(400)$ & 1 & 2.4 & 0.1 & 1.0 & 0.04 & 0.03 & 0.03 & $42-5$ \\
\hline $927-939$ & 0.3 & $23.9(75)$ & $204.4(400)$ & 1 & 2.5 & 0.1 & 1.0 & 0.04 & 0.03 & 0.025 & $42-6$ \\
\hline $927-939$ & 0.3 & $23.9(75)$ & $204.4(400)$ & 1 & 2.0 & 0.1 & 1.0 & 0.04 & 0.03 & 0.05 & $42-7$ \\
\hline $\begin{array}{c}1162-1170 \\
(3814-3840)\end{array}$ & 0.3 & $23.9(75)$ & $126.6(260)$ & 1 & 2.3 & 0.1 & 2.0 & 0.04 & 0.04 & 0.06 & $42-8$ \\
\hline $1162-1170$ & 0.3 & $23.9(75)$ & $204.4(400)$ & 1 & 2.3 & 0.1 & 2.0 & 0.04 & 0.03 & 0.06 & $42-9$ \\
\hline $1162-1170$ & 0.5 & $23.9(75)$ & $204.4(400)$ & 1 & 2.3 & 0.1 & 2.0 & 0.05 & 0.05 & 0.06 & $42-10$ \\
\hline
\end{tabular}

At formation temperature 
With slight variations from well to well in terms of optimum estimated value of $\mathrm{R}_{\text {wad }}$ and reservoir temperature, indications are that by and large a salinity of $20,000-30,000 \mathrm{ppm}$ (equivalent $\mathrm{NaCl}$ ) prevails in formation water. This is in line with geochemical studies reported by other investigators. ${ }^{8}$ One must note, however, that measurements made at surface are bound to result in somewhat different salinities because of the changes in the thermodynamic conditions of the produced fluid.

Lithology of the formation was briefly examined in the study. First using the cross plot of $\phi_{D}$ vs $\phi_{N}$ and as shown in part II of Appendix $C$, we determined the VSH parameter representing the shale content. From the four wells analyzed here, the VSH values decrease with depth. This is also confirmed by the Saraband results. Also, the average matrix density of the formation was determined according to the procedure shown in part IV of Appendix C. By and large, as shown in Fig. 5-8, the average matrix density is around 2.65 or perhaps somewhat higher. A cross plot of $\rho_{b}$ vs $\phi_{N}$ also shows that depending on the depth of the layers, the computed lithology varies from the sand shale series to more compact formations with $\rho_{b}$ higher than 2.65 . We are planning to examine this further in our future studies.

\section{SUMMARY AND CONCLUSIONS}

From the application of oilfield interpretation technology to the well logs of the Cerro Prieto Geothermal Field, we have reached the following conclusions:

1. For the sand-shale series formation, the existing technology is applicable as long as accurate estimates of formation temperature, borehole temperature, and drilling fluid properties can be established.

2. At the present time, logging tools that can survive extreme conditions of temperature and corrosive environment are not available. Consequently, the drilling fluid needs to be cooled. We recommend, therefore, that a thermistor be incorporated in all resistivity devices making it possible to record the wellbore temperature continuously during the logging operations. Such temperature data may be used to estimate formation temperature by applying the temperature buildup equation. 15 Furthermore, a continuous recording of $R_{m}$ with depth is imperative for meaningful interpretation of electric logs in a constantly changing environment. 


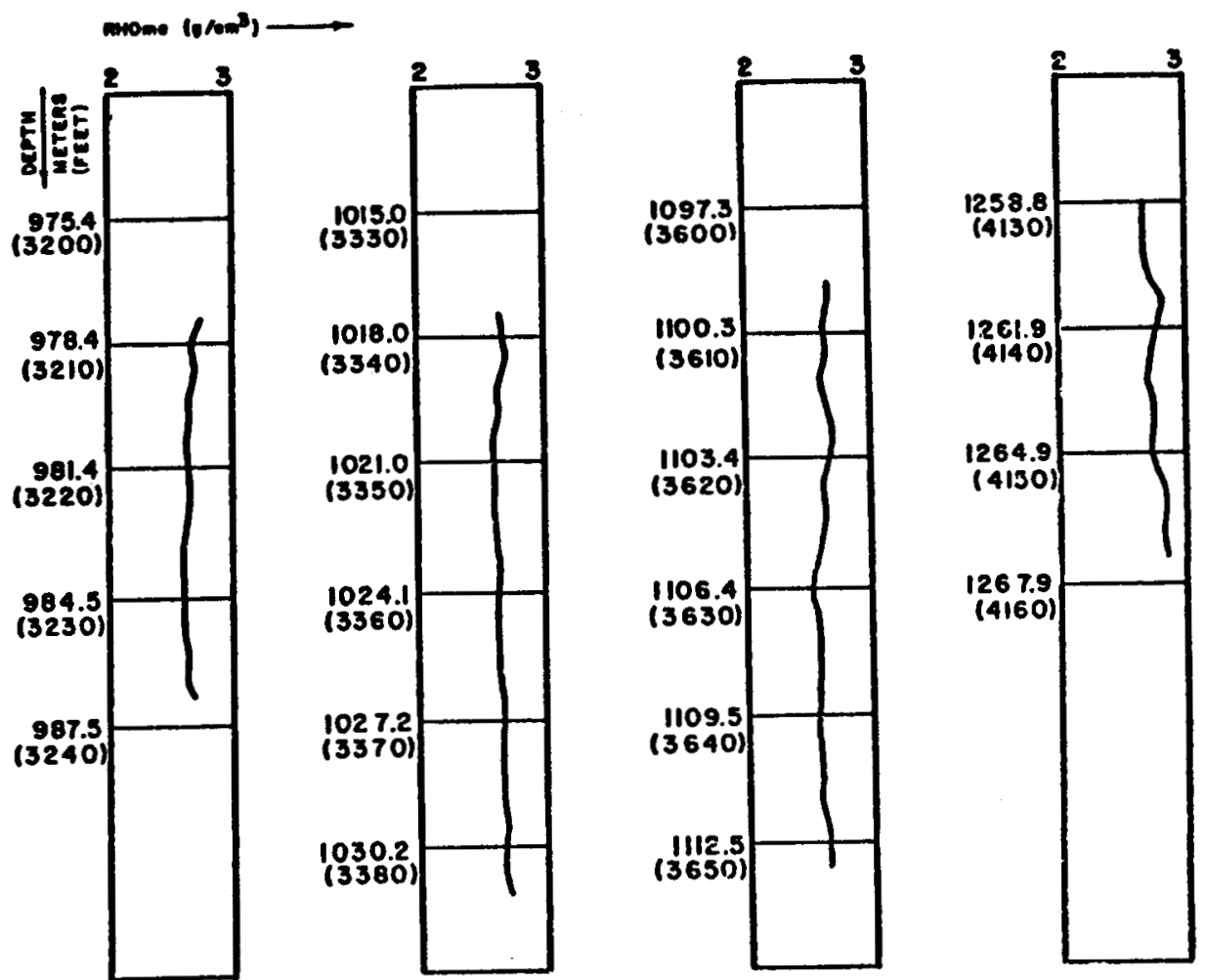

Fig. 5. Matrix density profile vs depth for Well 14.

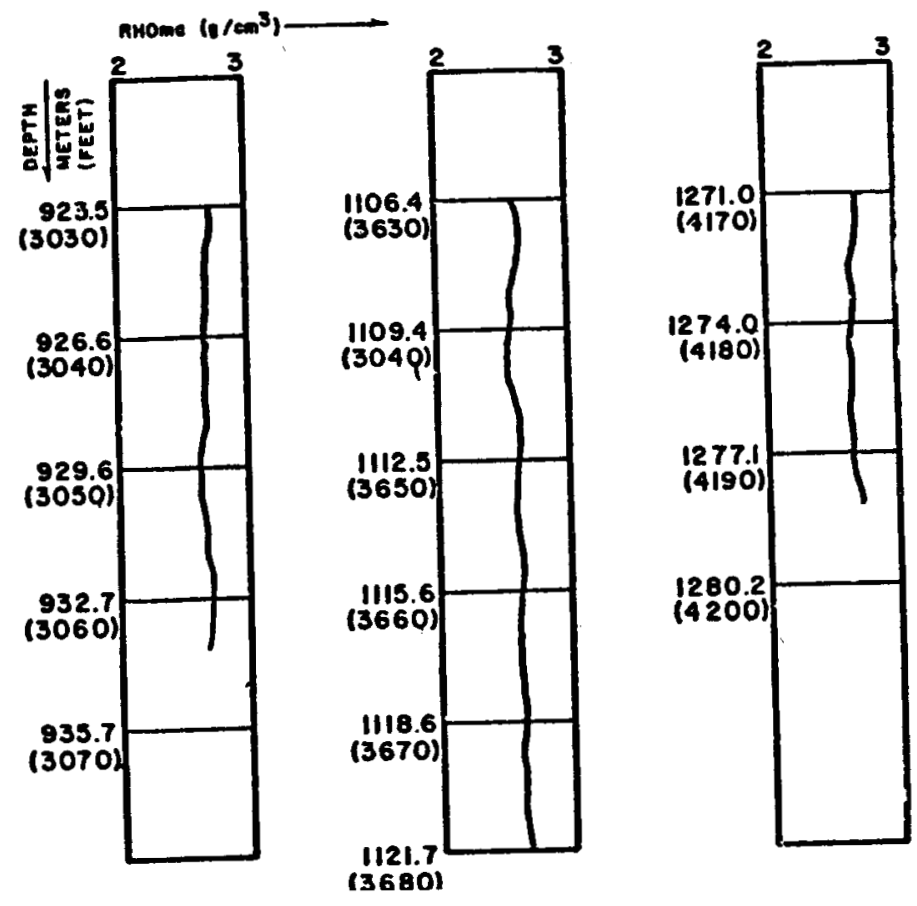

Fig. 6. Matrix density profile vs depth for Well 27. 


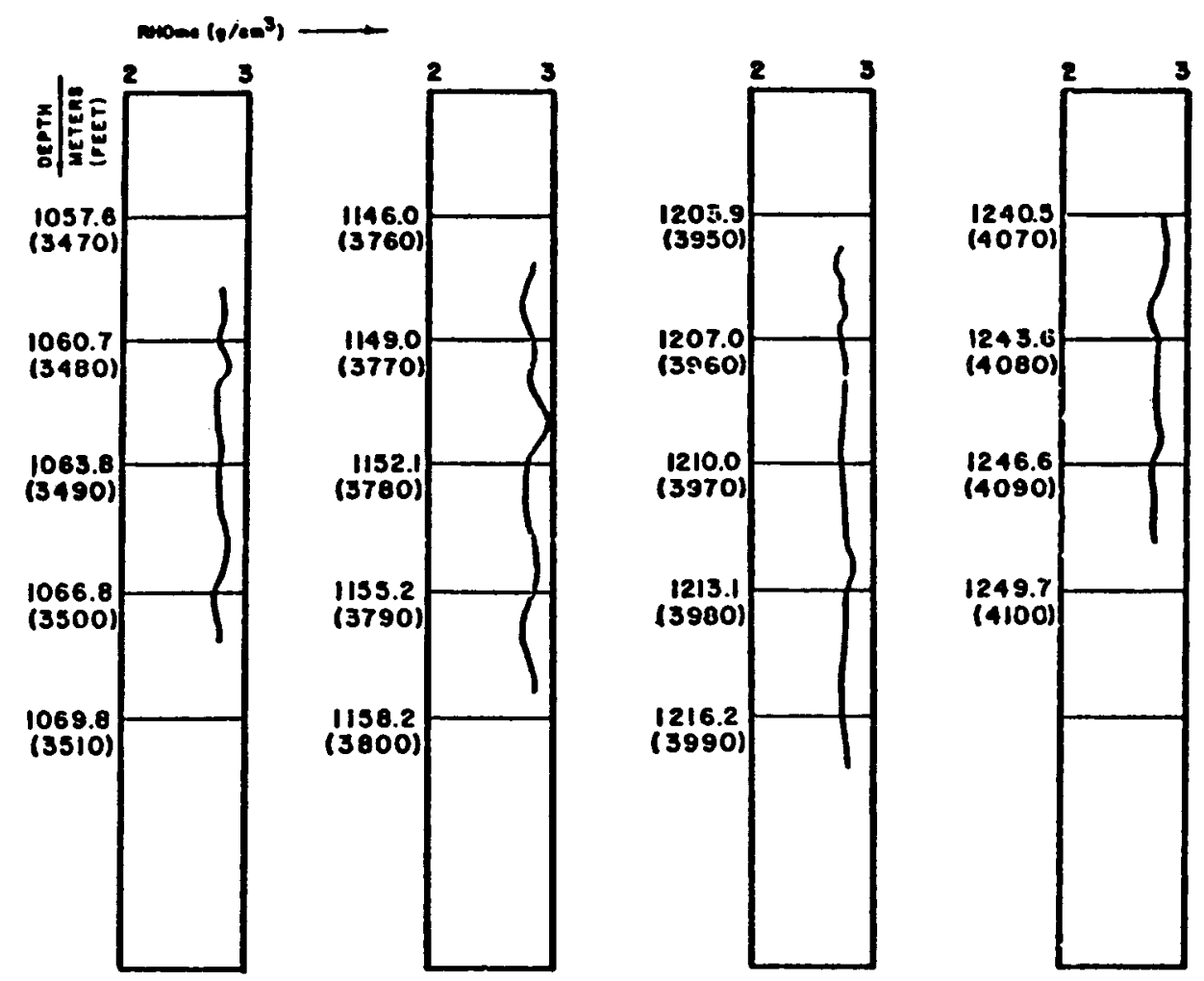

Fig. 7. Matrix density profile vs depth for Well 29.
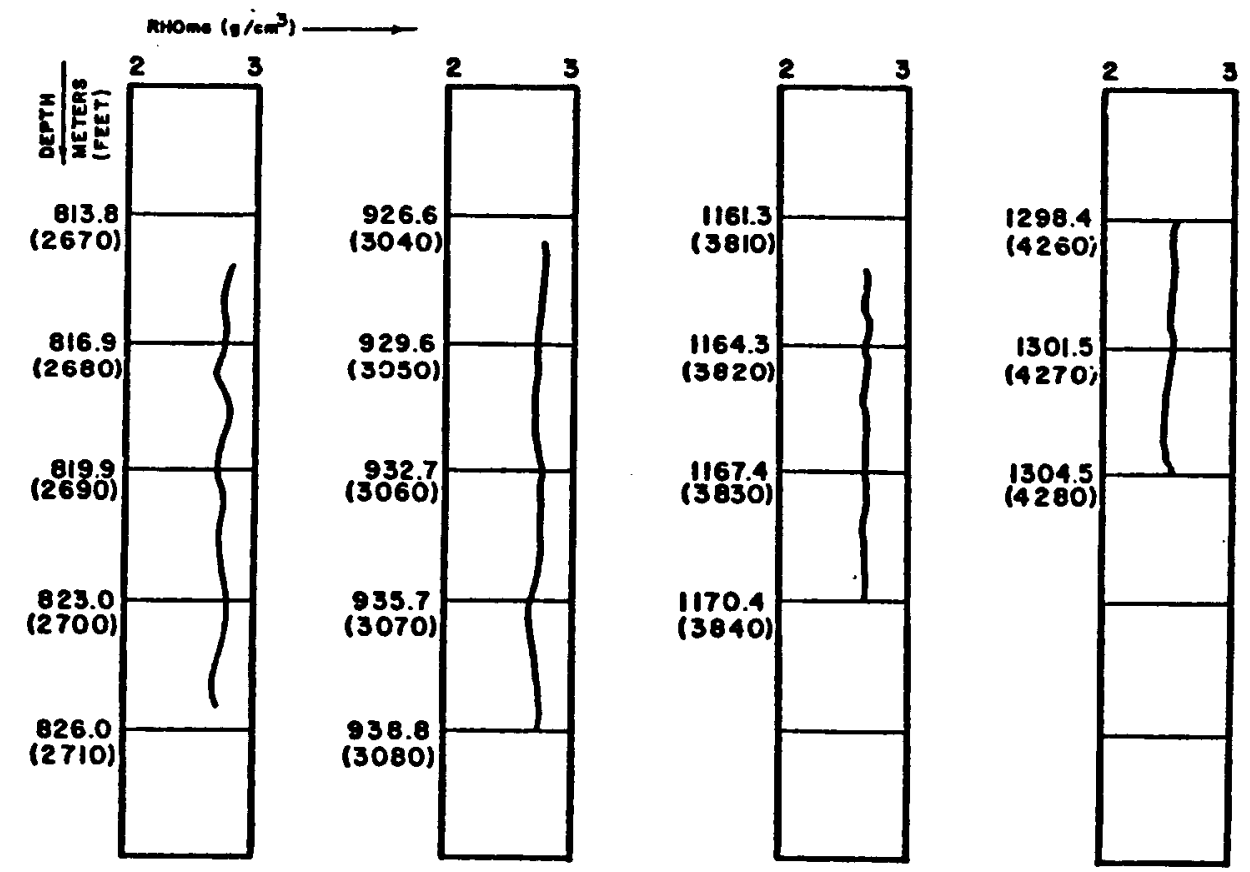

Fig. 8. Matrix density profile vs depth for Well 42. 
3. Calibration checks, and in particular, repeat sections must always be included with the logs.

4. SP logs can serve an important role in establishing geological correlations. We recommend that an overlay of Gamma Ray and SP logs be made as a routine check to detect unusual lithology or trouble spots.

5. The SP equation, as currently used, needs to be re-examined in terms of the possible effect of elevated temperature on different potential components.

6. The Dual-Induction Laterolog should in all cases be preferred to a conventional IES. The invasion radius computed from the $10 \mathrm{~g}$ is an additional check on testing the feasibility of using the proposed method to estimate reservoir temperature and formation fluid salinity.

7. From the computation of VSH vs depth using a cross plot of $\phi_{D} v s \phi_{N}$ and combining the results with the changes of deep induction $10 \mathrm{~g}$ with depth, the hydrothermal alteration of the rocks with depth may be identified.

8. The analysis presented in this report consists of using a simple geologic model for a complex lithology. The computed results represent a rough estimation of formation rock and fluid properties. Upgrading of results requires that calibration data be available for hydrothermally altered rocks and geologic models incorporating a realistic representation of the rock mineral content. Some refinements to the cross plot analysis could have been made if acoustic $\log$ data were available.

\section{ACKNOWLEDGMENTS}

The Los Alamos Scientific Laboratory supported this study through research contract L28-1923E. Several students in petroleum engineering assisted in digitization of logs and compilation of the data base. In particular we would like to thank M. Ramazani, K. Stilwell, R. Dorovi, I. Kim, E. Wright, and S. Marine11o.

M. J. Lippmann and J. Noble from the Lawrence Berkeley Laboratory were extremely helpful in providing the copies of the logs from the LBL inventory. We also wish to thank Ing. Abril from CFE for his assistance in securing copies of certain well logs. 


\section{REFERENCES}

1. J. E. Noble, A. Manon M., M. J. Lippmann, and P. A. Witherspoon, "A Study of the Structural Control of Fluid Flow Within the Cerro Prieto Geothermal Field, Baja California, Mexico," SPE 6763, paper presented at the 52nd Annual Fall Meeting of SPE, Denver, CO (Oct. 9-12, 1977).

2. I. P. Cruz, "Geology of the Cerro Prieto Geothermal Field," paper presented at the First Symposium on the Cerro Prieto Geothermal Field, sponsored by U. S. DOE and the Comision Federal de Electricidad de Mexico, San Diego, CA (Sept. 20-22, 1978).

3. W. A. Elders, J. R. Hoagland, and E. R. 01son, "Hydrothermal Mineralogy and Isotopic Geochemistry in the Cerro Prieto Geothermal Field, Mexico. III. Practical Applications," Transactions, Geothermal Resources Council Annual Meeting, Hilo, HI (July 25-27, 1978).

4. W. A. Elders, J. R. Hoagland, S. D. McDowe11, and J. M. Cobo, "Hydrothermal Mineral Zones in the Geothermal Reservoir of Cerro Prieto, B. C., Mexico," paper presented at the First Symposium on the Cerro Prieto Geothermal Field, sponsored by U. S. DOE and the Comision Federal de Electricidad de Mexico, San Diego, CA (Sept. 20-22, 1978).

5. J. R. Hoagland, and W. A. Elders, "Hydrothermal Mineralogy and Isotopic Geochemistry in the Cerro Prieto Geothermal Field, Mexico. I. Hydrothermal Mineral Zonation," Transactions, Geothermal Resources Council Annual Meeting, Hilo, HI (July 25-27, 1978).

6. W. A. Elders, E. R. Olson, J. R. Hoagland, C. E. Barker, P. D. Johnson, and P. Collier, "A Comprehensive Study of Samples from Geothermal Reservoirs: Petrology and Light Stable Isotope Geochemistry of Wells $M-48, M-84, M-90, M-91, M-92$, and Prian No. 1 in the Cerro Prieto Geothermal Field, Baja California, Mexico," Univ. of Calif. Riverside report UCR/IG, pp. $37 / 77$ (Dec. 1977).

7. M. J. Lippmann, B. D. Aguirre, H. A. Wollenberg, and P. A. Witherspoon, "Open File Data on the Cerro Prieto Geothermal Field," Lawrence Berkeley Laboratory report LBL-6321 UC-66b TID-4500-R65 (April 1977).

8. A. Manon, E. Mazor, M. Jimenez, S. Sanchez, J. Fausto, and C. Zenizo, "Extensive Geochemical Studies in the Geothermal Field of Cerro Prieto, Mexico," Lawrence Berkeley Laboratory report LBL-7019 UC-66 TID-4500-R66, (Dec. 1977).

9. G. S. Mercado, "Movement of Geothermal Fluids and Temperature Distribution in the Cerro Prieto Geothermal Field, Baja California, Mexico, Proceedings Second Symposium on the Development and Use of Geothermal Resources, San Francisco, CA (May 20-29, 1975) p. 457-494.

10. J. A. Krug and D. 0. Cox, "Shaly Sand Crossplot -- a Mathematical Treatment," The Log Analyst, SPWLA, Houston, TX (July-Aug. 1976) p. 11. 
11. R. C. Ransom, "Methods Based on Density and Neutron Well-Logging Responses to Distinguish Characteristics of Shaly Sandstone Reservoir Rock," The Log Analyst, SPWLA, Houston, TX (May-June 1977) p. 47.

12. J. J. Arps, "The Effect of Temperature on the Density and Electrical Resistivity of Sodium Chloride Solutions," Trans. AIME, vol. 198 (1953) pp. 327-330.

13. H. Ucok, I. Ershaghi, and G. R. Olhoeft, "Electrical Resistivity of Geothermal Brines," SPE 7878, paper presented at the 1979 SPE of AIME International Symposium on Oilfield and Geothermal Chemistry, Houston, TX (Jan. 22-24, 1979).

14. M. J. Edwardson, H. M. Girner, H. R. Parkinson, C. D. Williams, and C. S. Mathews, "Calculation of Formation Temperature Disturbances Caused by Mud Circulation," J. Petr. Tech. (April 1962) pp. 416-426.

15. W. L. Dowdle and W. M. Cobb, "Estimation of Static Formation Temperature from Well Logs," J. Petr. Tech. (Nov. 1975) pp. 1326-1330.

16. R. M. Bateman and C. E. Konen, "Wellsite Log Analysis and the Programmable Pocket Calculator," Paper B, SPWLA Transactions (1977).

17. E. A. Maciula and J. E. Cochran, "Quantitative Use of Calibration Data to Correct Miscalibrated Well Logs," J. Petr. Tech. (July 1968) p. 663.

18. J. E. Cochran, "Principles of Log Calibration and Their Application to Log Accuracy," J. Petr. Tech. (July 1966) p. 817. 
APPENDIX A

REVIEW OF LOG QUALITY

DATA

No calibration data nor repeat sections were available for the following wells:

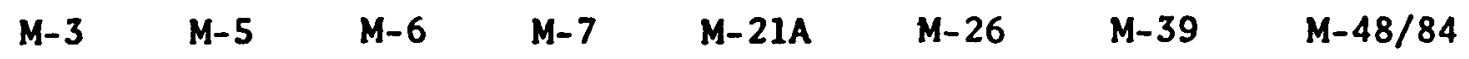

For logs for which calibration data and/or a repeat section were available for analysis, the data will be presented in the following format:

\section{Repeat}

Calibration

We11\# - Log Type* - Section? - Match? - ? - $\Delta-\delta-\sigma-$

.....where $\Delta$ is the high calibration point error,

$\delta$ is the low calibration point error, and $\sigma$ is the recorder offset error $;. .$.

.....as defined by Maciula and Cochran. 17-18

Question marks are answered by Yes/No, and error function values are given in the appropriate units for the $\log$ in question (i.e., ohm-meters, resistivity units, etc.l. Pertinent comments will follow each data set where necessary. *an EL $\log$ is the earlier version of the IES $\mathrm{log}$.

Repeat

\begin{tabular}{|c|c|c|c|c|c|c|c|c|c|c|c|}
\hline & - & Log Type & - & Section? & - & Match? & - & $?$ & - & - & $\sigma$ \\
\hline
\end{tabular}

Some ILD electric zero drift is apparent although there is a perfect repeat section match.

CNL Yes $\quad$ Yes $\quad$ Yes $00 \begin{array}{llll}0 & 0 & 0\end{array}$

Two complete runs made due to tool failure on first. Excellent match where first run data available.

M-19A

EL

FDC

No

No

No

DIL

No

No

No

Yes

Yes

Yes

0

0

0

M-20

EL

Yes

Yes

No

Repeat on different scale, but appears to match.

M-21 EL Yes Yes No

Repeat on different scale, but appears to match.

M-25

DIL

(to 2273')

DIL

(2350-4610')

CNL
Yes

Yes

No
Yes

Yes

No
Yes

$+5$

No

No 
Repeat

Calibration

\begin{tabular}{|c|c|c|c|c|c|c|c|c|c|c|c|c|c|}
\hline We11\# & & Log Type & - & Section? & - & Match? & - & $?$ & - & $\Delta$ & $\delta$ & $\sigma$ & - \\
\hline M-27 & & $\begin{array}{c}\text { IES } \\
\text { CNL } \\
\text { gamma }\end{array}$ & & $\begin{array}{l}\text { Yes } \\
\text { No } \\
\text { No }\end{array}$ & & $\begin{array}{l}\text { Yes } \\
\text { No } \\
\text { No }\end{array}$ & & $\begin{array}{l}\text { Yes } \\
\text { Yes } \\
\text { Yes }\end{array}$ & & $\begin{array}{l}0 \\
0\end{array}$ & $\begin{array}{r}0 \\
0 \\
0 K\end{array}$ & $\begin{array}{l}0 \\
0\end{array}$ & \\
\hline
\end{tabular}

CNL and gamma good only from 3900' down on second pass.

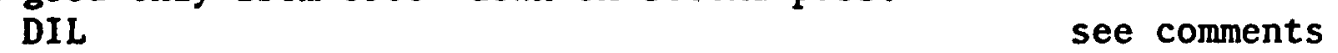

Electrical zero on sonde errors (high calibration point) both in error.

Elec. Zero shifted $40 \mathrm{ohm}-\mathrm{m}$ during survey. The ILM error shifted -4 units from the surface test to the before survey test and +32 units during the run for a total drift of 28 units. The ILD errors were $-35+70$, for a total error of +35 units. This $\log$ should be rerun.

M-29

$\begin{array}{ccccccc}\text { IES } & \text { Yes } & \text { Yes } & \text { Yes } & 0 & 0 & 0 \\ \text { FDC } & \text { Yes } & \text { No } & \text { Yes } & \text { see comments } \\ \text { gamma } & \text { Yes } & \text { No } & \text { No } & & \end{array}$

There was no drift in the $10 \mathrm{~g}$ density reading, but there was a drift of -0.1 for the change in density reading which contributed to a very small jig response error. As the repeat sections did not match for the FDC or the gamna ray, a rerun might be in order.

\begin{tabular}{cccccccc}
\multirow{2}{*}{ M-30 } & CNL & Yes & No & Yes & 0 & 0 & 0 \\
& IES & Yes & Yes & No & & & \\
& DIL & No & No & No & & & \\
& FDC & Yes & comments & Yes & 0 & 0 & 0
\end{tabular}

No surface calibration, just before and after survey. Repeat matches perfectly at times and at other times there is some small variance.

$\begin{array}{llllllll}M-31 & \text { EL } & \text { Yes } & \text { Yes } & \text { No } & & & \\ M-35 & \text { DIL } & \text { No } & \text { No } & \text { Yes } & 0 & 0 & 0 \\ M-38 & \text { EL } & \text { Yes } & \text { Yes } & \text { No } & & & \\ M-42 & \text { IES } & \text { Yes } & \text { Yes } & \text { Yes } & 0 & 0 & 0 \\ & \text { DIL } & \text { Yes } & \text { Yes } & \text { Yes } & 0 & 0 & 0\end{array}$

Surface calibration not included, but beginning and end zero traces match.

$\begin{array}{ccccccc}\text { CNL } & \text { Yes } & \text { Yes } & \text { Yes } & 0 & 0 & 0 \\ \text { gamma } & \text { Yes } & \text { Yes } & \text { Yes } & \text { OK } & \end{array}$

Repeat section match is not identical. All peaks in the same places, but sometimes magnitudes are not exactly the same. Differences both plus and minus.

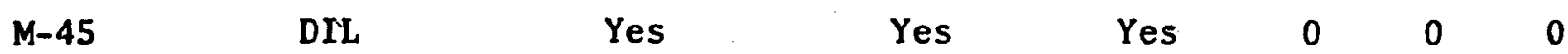
After survey calibrations somewhat erratic, but averages match before values. $\mathrm{T}=318^{\circ} \mathrm{F}$.

$\begin{array}{cllllll}\text { IES } & \text { Yes } & \text { Yes } & \text { Yes } & 0 & 0 & 0 \\ \text { FDC } & \text { Yes } & \text { Yes } & \text { Yes } & 0 & 0 & 0 \\ \text { gamma } & \text { No } & \text { No } & \text { No } & & & \end{array}$

FDC repeat section almost identical, but some variance at times. Gamma ray not working on repeat. 
Repeat

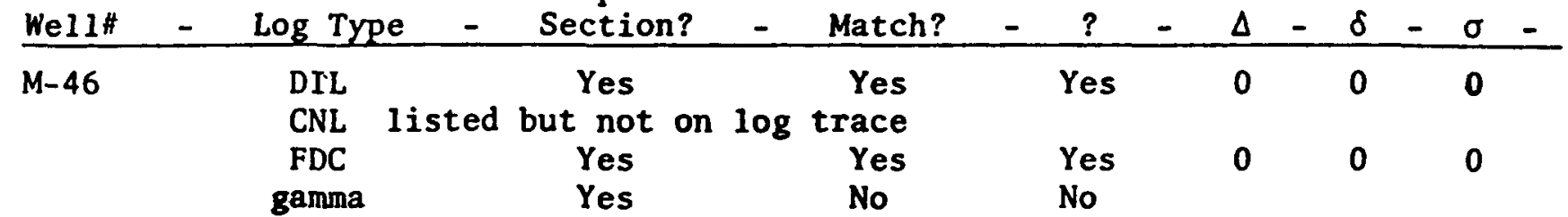

After survey FDC calibration may be faked. Tool malfunctioned at 3200'; compensator went out, so calibration not possible unless tool started working again. Curve may be readjusted assuming constant compensator deviation and linear response, but curve may be bouncing on the tool and recorder limit. Gamma ray repeat does not match at all. $T=346^{\circ} \mathrm{F}$; the tool 1 imit is $350^{\circ} \mathrm{F}$. Overall accuracy in question. All time constants check for repeat and original runs.

M-51

EL Yes

Yes

Yes

No

DIL

Yes

Yes $+4 \quad 0 \quad 0$

Before survey calibration shows positive error. After survey calibration is zero.

M-53

DIL

FDC

No
Yes

No

No

Yes

0

$0 \quad 0$ 
FLOW DIAGRAM OF THE COMPUTER PROGRAM

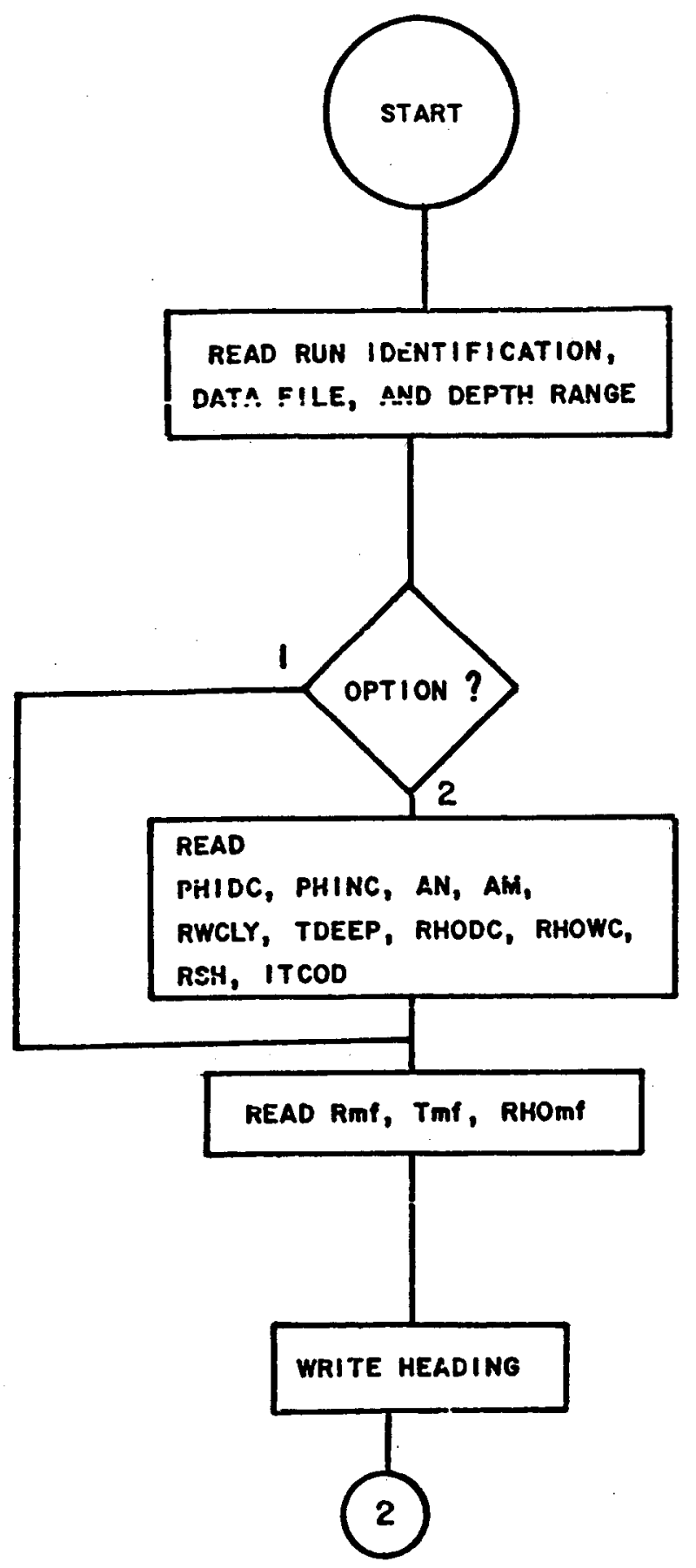

Fig. B-1. Flow Diagram of Computer Program 


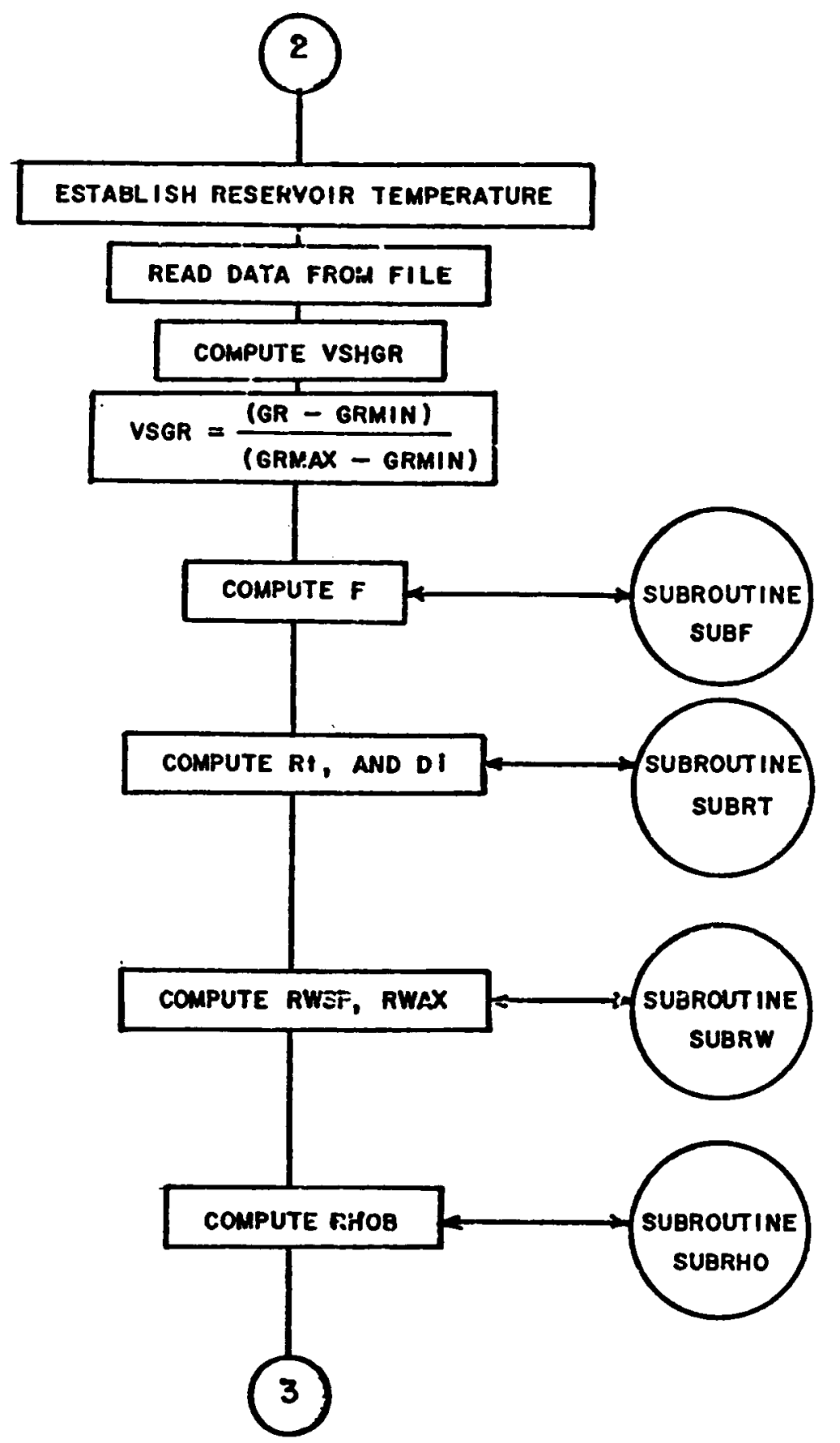

Fig. B-2. Flow Diagram (con't.) 


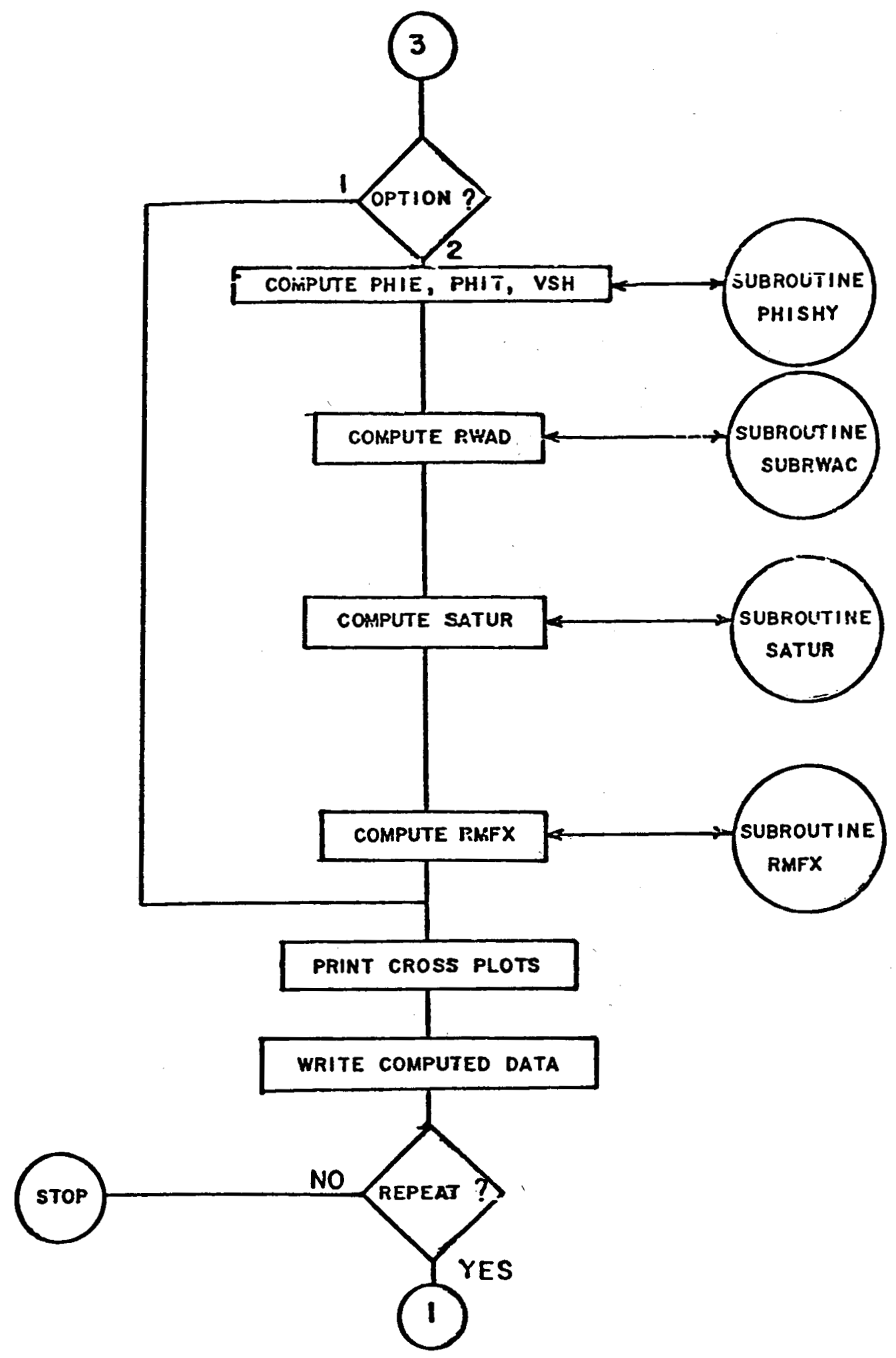

Fig. Br3. Flow Diagram (con't.). 
Description of Subroutines

\begin{tabular}{|c|c|c|}
\hline SUBF & Compute $\mathrm{F}$ & $F=a / \phi m$ \\
\hline SUBRT & Compute $R_{t}, R_{x o}$ and $D i$ & Part I Appendix C \\
\hline SUBRW & $\begin{array}{c}\text { Compute } R_{\text {wa }} \text { from } S_{p} \\
\text { and } R_{\text {xo }}\end{array}$ & $\begin{array}{l}\text { Part III-1 } \\
\text { Part III-2 }\end{array}$ \\
\hline SUBRHO & Compute $\rho_{\mathrm{ma}}$ & Part IV Appendix C \\
\hline PHISHY & Compute $\phi_{e}, \phi_{t}, v S H$ & Part II Appendix C \\
\hline SUBRWAC & $\mathrm{R}_{\text {WAD }}$ & Part III-3 Appendix C \\
\hline SATUR & $S_{w}$ & Part V Appendix C \\
\hline RMFX & Optimum $R_{m f}$ & Equation 2-6 Text \\
\hline
\end{tabular}




\section{APPENDIX C}

\section{SUMMARY OF EQUATIONS}

I. Computation of $R_{t}$ and $D_{i}$ from the Dual-Induction Laterolog ${ }^{16}$

$$
R_{t}=R_{\text {ILD }} \times \text { Ratio }
$$

where

$$
\begin{aligned}
& \text { Ratio }=\frac{R_{\text {ILM }}(\text { GID }- \text { GIM) }}{\text { GID } \times R_{\text {ILD }}-\text { GIM } \times R_{\text {ILM }}} \\
& G I D=0.0096 D_{i}-0.34+A L P H-B E T \\
& A L P H=10^{\left(0.001\left(156-53 D_{i}\right)\right)} \\
& B E T=10^{\left(0.001\left(25 D_{i}-3780\right)\right)} \\
& G I M=0.0123 D_{i}-0.212-0.0037 e^{\left(0.04 D_{i}\right)} \\
& G_{L L 8}=\frac{\left(D_{i}-20\right)}{1.21 D_{i}+20}+0.343 \\
& D_{i}=\frac{-B+\sqrt{B^{2}-4 A C}}{2 A} \\
& A=Y-0.52 \times-0.46 \\
& B=-(33 y+23 x+90) \\
& C=269 Y+530 x+1589 \\
& X=\frac{\left(R_{L L 8}-R_{I L D}\right)}{\left(R_{I L M}-R_{I L D}\right)} \\
& Y=\frac{\left(R_{L L 8}-R_{I L D}\right)}{\left(R_{I L M}-R_{I L D}\right)}
\end{aligned}
$$


II. Computation of VSH, $\phi_{e}$ and $\phi_{t}{ }^{10}$

$$
\begin{aligned}
& \phi_{t}=\phi_{e}+V S H \phi_{e} \\
& \phi_{C}=\frac{\left(\rho_{D C}-\rho_{O W C}\right)}{\left(\rho_{D C}-\rho_{O W}\right)} \\
& V S H=\frac{B}{A L 2} \\
& \phi_{e}=\frac{A}{A L 1} \\
& A L 1=\sqrt{2} \sin (\omega) \\
& \mathrm{AL2}=\sqrt{\phi_{\mathrm{NC}}^{2}+\phi_{\mathrm{DC}}^{2}} \sin (\omega) \\
& \omega=\frac{\pi}{4}-\theta \\
& \mathrm{T}_{\text {avg }}(\theta)=\frac{\phi_{\mathrm{DC}}}{\phi_{\mathrm{NC}}} \\
& A=\frac{\phi_{D}-T_{\text {avg }} \theta \phi_{N}}{\sqrt{t_{\text {avg }}^{2}(\theta)+1}} \\
& B=\frac{\phi_{N}-\phi_{D}}{\sqrt{2}} \\
& \rho_{w}=1.001735-0.00000456 T_{f}-0.000000890 T_{f}^{2} \\
& \text { (water density corrected for temperature) }
\end{aligned}
$$

39 
III. $R_{W S P}, R_{W A X}$, and $R_{W A D}$

1. R

$$
\begin{aligned}
& \text { For } R_{\text {mf }}>0.1 \mathrm{ohm}-\mathrm{m} \text { at } 75 \mathrm{~F}(23.9 \mathrm{C}) \\
& R_{m f e}=0.85 R_{m f} \\
& R_{\text {we }}=\frac{R_{\text {mf }}}{\text { Ratio }} \\
& \text { Ratio }=10\left(\frac{-S P}{60+.133 \mathrm{~T}_{f}}\right) \\
& \text { For } R_{\text {we }}<0.12 \\
& R_{w}=\frac{77 R_{w e}+5}{146-337 R_{w e}}
\end{aligned}
$$

2. R WAX

$$
\begin{aligned}
R_{W A X} & =\frac{R_{t}}{F_{x O}} \\
F_{x o} & =\frac{R_{L L 8}}{R_{m f f}} \quad\left(\begin{array}{c}
\left(R_{m f f} \text { is } R_{m f}\right. \\
\text { temperature })
\end{array}\right.
\end{aligned}
$$

3. $\mathrm{R}_{W A D}$

$$
\begin{aligned}
R_{W A D} & =\frac{\phi_{e}}{\phi_{t}\left(\frac{F}{R_{t}}-\frac{\phi_{t}-\phi_{e}}{\phi_{t}} \frac{1}{R_{w c 1 y}}\right)} \\
F & =\frac{a}{\phi_{t}^{m}}
\end{aligned}
$$

40 
IV. $\rho_{\mathrm{ma}}^{10}$

$$
\begin{aligned}
\rho_{\mathrm{ma}} & =\frac{\rho_{\mathrm{b}}-\phi_{\mathrm{x}} \rho_{\mathrm{mc}}}{1-\phi_{\mathrm{X}}} \\
\phi_{\mathrm{x}} & =\frac{\phi_{\mathrm{DA}} \phi_{\mathrm{N}}-\phi_{\mathrm{D}} \phi_{\mathrm{NA}}}{\phi_{\mathrm{DA}}-\phi_{\mathrm{NA}}} \\
\phi_{\mathrm{DA}} & =\frac{2.71-4}{2.71-\rho_{\mathrm{mf}}} \\
\phi_{\mathrm{NA}} & =0.7-10^{-\left(5 \phi_{\mathrm{N}}+0.16\right)}
\end{aligned}
$$

V. $S_{w}$

$$
S_{w}=\frac{-\frac{V S H}{R S H}+\sqrt{\left(\frac{V S H}{R S H}\right)^{2}+\frac{4\left(\phi_{e}\right)^{m}}{(a)\left(R_{w S P}\right)\left(R_{t}\right)(1-V S H)}}}{\frac{2 \cdot \phi_{e}{ }^{m}}{(a)\left(R_{w S P}\right)(1-V S H)}}
$$

(Simandoux's equation) *

\footnotetext{
${ }^{*}$ P. Simandoux, "Mesures Dielectrigues en Milieu Poreux, Application a Mesure des Saturations en Eau, Etude du Comportement des Manifs Argileux," Revue de 1'institut du Petrole, Supplementary Issue, 1963.
} 
APPENDIX D

INDIVIDUAL WELL SUMMARIES

The following sections are included for the four wells analyzed in this report:
1. Drilling Report
2. SP-Gamma Ray Overlay
3. Computed Results

The drilling summaries are translations of original documents which were in Spanish. These translations were obtained from the Lawrence Berkeley Laboratory and are included here to show the sequence of events prior to and after the downhole geophysical surveys. No editing is done on these reports to preserve the common language used in field practices.

The SP-Gamma Ray Overlays are included to show the quality of the SP logs.

Specific input data used for cases studied are shown for each table representing the computed results. The description of the output is as follows:

$$
\begin{aligned}
\text { SP } & =\text { SP reading from digitization } \\
\text { GR } & =\text { Ganma Ray reading from digitization } \\
\text { PHID } & =\text { Density Porosity reading from digitization } \\
\text { PHIN } & =\text { Neutron Porosity reading from digitization } \\
R_{t} & =\text { Computed } R_{t} \text { from Dual-Induction Laterolog } \\
\text { VSH } & =\text { Computed } V S H \text { from } \phi_{D}-\phi_{N} \text { Cross Plot } \\
\text { PHIE } & =\text { Computed } \phi_{e}
\end{aligned}
$$




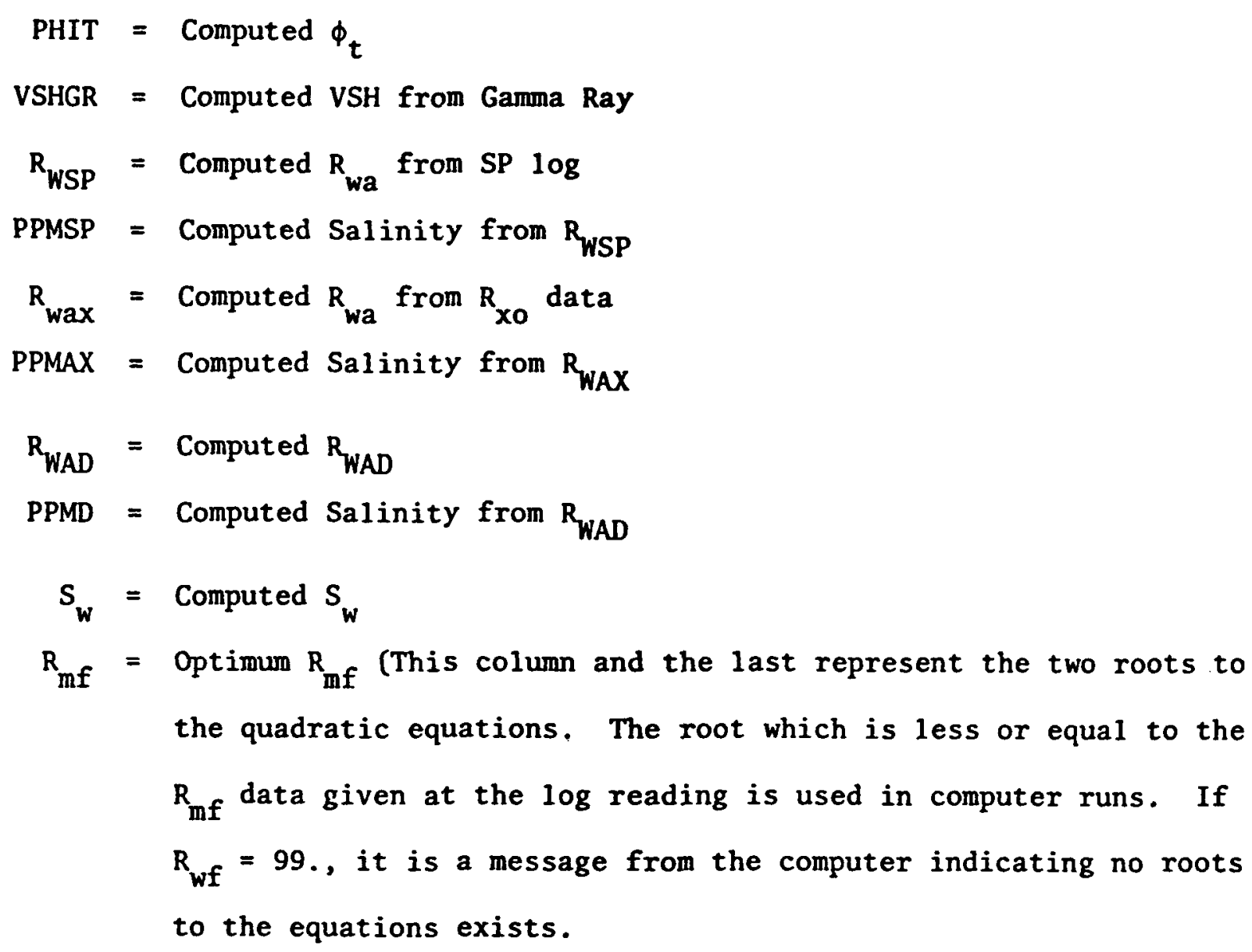
the quadratic equations. The root which is less or equal to the $R_{m f}$ data given at the $\log$ reading is used in computer runs. If $R_{w f}=99 .$, it is a message from the computer indicating no roots to the equations exists. 
DRILLING REPORT ON WELL M-14

LOCATION:

The calculation of the coordinates uses as origin the center of Unit Number 1 of the Cerro Prieto Geothermal Power Plant and are referred to the rehabilitation system for the irrigation district of the Department of Hydraulic Resources (DHR).

$$
\begin{aligned}
& X=16,951.64 \mathrm{~m} \\
& Y=1,631.10 \mathrm{~m}
\end{aligned}
$$

Elevation of the ground $=11.80 \mathrm{~m}$ above sea level (DHR).

This well was drilled in two stages with equipment from the PERFESA Company.

First stage with equipment $\mathrm{H}-35$, rotary table elevation $3.12 \mathrm{~m}$ above ground level.

Second stage with equipment $\mathrm{H}-40$, rotary table elevation $3.30 \mathrm{~m}$ above ground level.

It is located approximately $155.0 \mathrm{~m}$ northwest of well $\mathrm{M}-15,200 \mathrm{~m}$ north of well $\mathrm{M}-20$ and $195.0 \mathrm{~m}$ southwest of well M-39.

FIRST STAGE (Without constructing a cellar)

DRILLING $50.8 \mathrm{~cm}(20 " \emptyset)$ HOLE

On 13 November '73 at 6:00 hours drilling was started with a $38.10 \mathrm{~cm}$

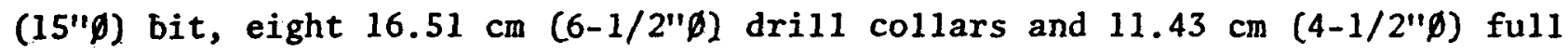
hole (F.H.) drill pipe, drilled plastic, light gray, slightly sandy clay from $0.0 \mathrm{~m}$ to $186.33 \mathrm{~m}$ below ground level (B.G.L.) where the inclination was taken with a ToTCo recorder obtaining a reading of $0^{\circ} 15^{\prime}$, continued drilling in the same formation down the $246.88 \mathrm{~m} \mathrm{B.G.L.,} \mathrm{took} \mathrm{inclination} \mathrm{with} \mathrm{ToTCO} \mathrm{recorder}$ obtaining a reading of $0^{\circ} 05^{\prime}$, resumed drilling down to $263.88 \mathrm{~m} \mathrm{B.G.L.,} \mathrm{pulled}$ out and removed $38.10 \mathrm{~cm}$ (15"Ø). bit, inserted $50.8 \mathrm{~cm} \times 38.1 \mathrm{~cm}$ (29" $\left.\times 15^{\prime \prime}\right)$ "Home Made" hole opener enlarged the hole from $0.0 \mathrm{~m}$ to $255.88 \mathrm{~m} \mathrm{B.G.L}$.

CEMENTING $40.64 \mathrm{~cm}$ (16"ø) CASING

At 5:30 hours on 18 November 173 .

Circulated, conditioned mud and hole, ran $40.64 \mathrm{~cm}$ (16"Ø) H-40 $96.70 \mathrm{~kg} / \mathrm{m}$ (65\#/ft) founded thread short coupling (R.T.S.C.) USS brand with the casing shoe placed at $252.88 \mathrm{~m} \mathrm{B.G.L.}$ 
With personnel and pumping equipment from B.J., cemented casing described above the 43.9 tons of cement modified with diamix in the proportion $1: 1$ in the form of grout of density 1.65, the excess cement came out satisfactorily to the surface, ordered 18 hours of setting starting at 2:50 hours on 19 November ' 73 . Afterwards cut off 16 inch casing provisionally at $0.71 \mathrm{~m} \mathrm{B.G.L.,} \mathrm{welded} \mathrm{the}$ 16" S-2000 well-head and installed blow-out preventer with blank and annular 4-1/2" $\emptyset$ rams.

\section{HYDRAULIC TEST}

Inserted $38.10 \mathrm{~cm}\left(15^{\prime \prime} \emptyset\right)$ bit, eight $16-51 \mathrm{~cm}\left(6-1 / 2^{\prime \prime} \emptyset\right)$ drill collars and $11.43 \mathrm{~cm}\left(4-1 / 2^{\prime \prime} \emptyset\right)$ drill pipe to $240.58 \mathrm{~m} \mathrm{B.G.L}$. Where top of cement was reached, closed annular rams for $11.43 \mathrm{~cm}\left(4-1 / 2^{\prime \prime} \emptyset\right)$ drill pipe; made hydraulic test of the 40.64 (16"D) casing and cementing, with $45.5 \mathrm{~kg} / \mathrm{cm}^{2}$ (650 psig) for 30 minutes, observed a decrease of $3.5 \mathrm{~kg} / \mathrm{cm}^{2}$, considered the test satisfactory.

DRILLING $38.10 \mathrm{~cm}\left(15^{\prime \prime} \emptyset\right)$ HOLE

At $21: 30$ hours on 21 November 173 .

With $38.10 \mathrm{~cm}\left(15^{\prime \prime}\right)$ bit, eight $16.51 \mathrm{~cm}\left(6-1 / 2^{\prime \prime \emptyset)}\right.$ drilling collars and $11.43 \mathrm{~cm}\left(4-1 / 2^{\prime \prime} \emptyset\right)$ F.H. drill pipe inside the $40.64 \mathrm{~cm}$ (16" $)$ casing cement drilled through plug, retainer collar and float shoe. Continued drilling in plastic sandy clay, coffee-colored light semi-compact shale from $255.88 \mathrm{~m}$ B.G.L. to $456.88 \mathrm{~m} \mathrm{B.G.L.} \mathrm{Starting} \mathrm{from} \mathrm{this} \mathrm{depth} \mathrm{an} \mathrm{increase} \mathrm{was} \mathrm{observed} \mathrm{in}$ the content of quartzitic sand, plastic clay and coffee-colored shales until $513.14 \mathrm{~m}$ B.G.L. where the inclination was taken with TOTCO recorder obtaining a reading of $0^{\circ} 5^{\prime}$, continued drilling in the same formation to $686.32 \mathrm{~m}$ below ground level where the inclination was taken with TOTCO recorder obtaining a reading $0^{\circ} 40^{\prime}$, continued drilling with increments in the percentage of sandstone, plastic clay, quartzitic sand, carbonaceous material, and traces of lignite to $793.93 \mathrm{~m} \mathrm{B.G.L}$. where inclination was taken with TOTCO recorder obtaining a reading of $0^{\circ} 20^{\prime}$, continued drilling in light gray sandstone, dark gray shale, to $808.90 \mathrm{~m}$ B.G.L., circulated, pulled out and removed $38.10 \mathrm{~cm}$ $\left(15^{\prime} \emptyset\right)$ bit. Assembled and inserted $26.98 \mathrm{~cm}\left(10-5 / 8^{\prime \prime} \emptyset\right)$ bit at $11: 15$ hours on 6 December 173 with the same continued drilling from $808.90 \mathrm{~m} \mathrm{B.G.L.} \mathrm{through}$ compact dark gray shale, poorly cemented whitish sandstone, quartzitic material to $994.58 \mathrm{~m} \mathrm{B.G.L.,} \mathrm{suspended} \mathrm{drilling} \mathrm{and} \mathrm{took} \mathrm{inclination} \mathrm{with}$ TOTCO recorder at $938.58 \mathrm{~m} \mathrm{B.G.L.} \mathrm{obtaining} \mathrm{a} \mathrm{reading} \mathrm{of} 1^{\circ} 00^{\prime}$, later on 
pulled out and removed $26.99 \mathrm{~cm}\left(10-5 / 8^{\prime \prime} \mathrm{D}\right)$ bit; assembled and inserted 38.10 $\mathrm{cm}$ (15"ø) bit enlarging the hole from $808.90 \mathrm{~m}$ B.G.L. to $944.88 \mathrm{~m} \mathrm{B.G.L}$. continuing the arilling from $944.58 \mathrm{~m}$ B.G.L. to $954.88 \mathrm{~m} \mathrm{B.G.L.,} \mathrm{recovered}$ dark gray shale, cemented sandstone and quartzitic material.

\section{GEOPHYSICAL LOGS}

With personnel and equipment from the Schlumberger Co. obtained induction $\log$ from 256.71 to $957.34 \mathrm{~m}$ below rotary table (B.R.T.) (842-3142') and micro

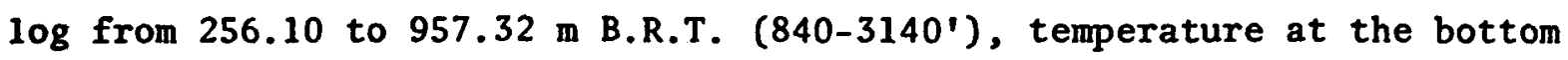
$104.4^{\circ} \mathrm{C}$.

CEMENTING $29.85 \mathrm{~cm}\left(11-3 / 4^{\prime \prime} \emptyset\right)$ CASING

Inserted $38.10 \mathrm{~cm}\left(15^{\prime \prime} \emptyset\right)$ bit, eight $16.51 \mathrm{~cm}\left(6-1 / 2^{\prime \prime} \emptyset\right)$ drill collars and $11.43 \mathrm{~cm}$ (41"Ø) F.H. drill pipe noting light resistance at $396.42 \mathrm{~m} \mathrm{B.G.L.} \mathrm{and}$ from $776.47 \mathrm{~m} \mathrm{B.G.L.} \mathrm{to} 786.18 \mathrm{~m} \mathrm{B.G.L.,} \mathrm{finished} \mathrm{inserting} \mathrm{it} \mathrm{to} 954.88 \mathrm{~m}$ B.G.L. where mud and hole were conditioned, at 5:00 hours on 14 December 73 made preparations and necessary connections, running $29.85 \mathrm{~cm}(11-3 / 4 " \emptyset) \mathrm{N}-80$ Youngstown, buttress thread (B.T.) of $89.5 \mathrm{~kg} / \mathrm{m}(60 \mathrm{lb} / \mathrm{foot})$ and $\mathrm{K}-55$, NKK, B.T. of $69.9 \mathrm{~kg} / \mathrm{m}(47 \mathrm{lb} / \mathrm{foot})$ casing, encountering heavy resistance at the following depths: $289.69,373.73,385.74$, and $397.73 \mathrm{~m} \mathrm{B.G.L.,} \mathrm{circulated} \mathrm{and}$ worked on the casing pipe. Later on continued running again detecting strong resistance at 440.77 to $445.77 \mathrm{~m} \mathrm{B.G.L}$. with maximum tensions of 68.2 tons $(150,000 \mathrm{lb})$, upon observing signs of sticking decided at 17:15 hours on 14 December 173 to pull out the casing pipe, operation which was completed at 12:30 hours on 15 December 173 observed loss of retaining ring and centralizer of the last section, which remained inside the well. Assembled fishing tool ("Home Made" spear) followed by $11.43 \mathrm{~cm}(4-1 / 2 " \emptyset)$ drill pipe, lowered to $472.90 \mathrm{~m}$ B.G.L. where resistance was encountered, operated and removed fishing tool with two parts of the centralizer (20\%]. Inserted $38.10 \mathrm{~cm}$ (15'0) bit, eight $16.51 \mathrm{~cm}\left(6-1 / 2^{\prime \prime \emptyset)}\right.$ drilling collars and $11.43 \mathrm{~cm}\left(4-1 / 2^{\prime \prime \emptyset) ~ F . H . ~ d r i l l ~ p i p e ~}\right.$ to $496.16 \mathrm{~m} \mathrm{B.G.L.} \mathrm{where} \mathrm{resistance} \mathrm{was} \mathrm{observed,} \mathrm{starting} \mathrm{from} \mathrm{this} \mathrm{depth}$ inserted pipe by pipe to $954.88 \mathrm{~m} \mathrm{B.G.L.} \mathrm{brought} \mathrm{out} \mathrm{bit} \mathrm{at} \mathrm{the} \mathrm{shoe} \mathrm{(16" \emptyset )}$ casing inserting it again to $954.88 \mathrm{~m} \mathrm{B.G.L.} \mathrm{where} \mathrm{mad} \mathrm{and} \mathrm{hole} \mathrm{were}$ conditioned. 
CEMENTING $29.84 \mathrm{~cm}\left(11-3 / 4^{\prime \prime} \emptyset\right)$ CASING

At 17:15 hours on 18 December 173 carried out preparations and necessary connections to run $29.84 \mathrm{~cm}\left(11-3 / 4^{\prime \prime} \emptyset\right) \mathrm{N}-80$ Youngstown B.T. $89.5 \mathrm{~kg} / \mathrm{m}$ (60 lb/foot) and K-55 NKK, B.T. $69.9 \mathrm{~kg} / \mathrm{m}$ (47 1b/foot) casing, strong resistance was observed at 440.77 and $447.77 \mathrm{~m} \mathrm{B.G.L.,} \mathrm{worked} 52.3$ tons $(115,0001 \mathrm{~b})$, circulated, continued to try to insert the casing working it down to $452.60 \mathrm{~m}$ B.G.L. observing maximum tension of 59.1 tons $(130,0001 \mathrm{~b})$, circulated and worked the casing down to $455.50 \mathrm{~m} \mathrm{B.G.L.} \mathrm{observing} \mathrm{a} \mathrm{maximum} \mathrm{tension} \mathrm{of} 68.2$ tons $(150,000 \mathrm{lb})$, worked the casing until tension decreased to 45.5 tons $(100,000 \mathrm{1b})$; circulated and worked the casing to $460.61 \mathrm{~m} \mathrm{B.G.L.} \mathrm{observing}$ maximum tension of 63.6 tons $(140,000 \mathrm{lb})$ and decided therefore to recover the casing starting at 8:15 hours on 19 December 174, an operation which was completed at 11:00 hours on 20 December 174, conditioned mud in pits, assembled $38.10 \mathrm{~cm}\left(15^{\prime \prime} \emptyset\right)$ bit, eight $16.51 \mathrm{~cm}\left(6-1 / 2^{\prime \prime}\right)$ drill collars, $11.43 \mathrm{~cm}\left(4-1 / 2^{\prime \prime \emptyset)}\right.$ F.H. drill pipe and inserted (pipe by pipe).

Without noticing resistance, little recovery of clay until $446.70 \mathrm{~m} \mathrm{B.G.L.,}$ took inclination with TOTCO recorder with a reading of $0^{\circ} 58^{\prime}$, continued going through again to $463.58 \mathrm{~m}$ B.G.L., took inclination with TOTCO equipment with a reading of $1^{\circ}$, continued going over again to $860.18 \mathrm{~m} \mathrm{B.G.L.} \mathrm{without} \mathrm{observing}$ neither resistance nor high contents of clay in the discharge. Pulled out to. the surface and inserted the same drilling column again to $859.88 \mathrm{~m} \mathrm{B.G.L.}$ where resistance was noted, inserted pipe by pipe to $954.88 \mathrm{~m} \mathrm{B.G.L.,} \mathrm{circulated}$ at that point, pulled out drilling column to the surface, connected a section of drill pipe to the kelly and closed the annular rams of the preventer. Operations suspended at 12:00 hours on 24 December 174 for Christmas.

ENLARGING HOLE TO $44.45 \mathrm{~cm}\left(17-1 / 2^{\prime \prime} \emptyset\right)$

On 27 December 174.

Installed $44.45 \mathrm{~cm}\left(17-1 / 2^{\prime \prime}\right)$ model 10-KWA baker hole opener with $38.10 \mathrm{~cm}$ (15"ø) pilot bit, eight $16.51 \mathrm{~cm}\left(6-1 / 2^{\prime \prime}\right)$ drill collars and $11.43 \mathrm{~cm}\left(4-1 / 2^{\prime \prime} \emptyset\right)$ drill pipe inserted to $342.84 \mathrm{~m} \mathrm{B.G.L.} \mathrm{where} \mathrm{resistance} \mathrm{was} \mathrm{encountered,}$ circulated, prepared and conditioned mud, operated the hole opener from 345.84 to $662.28 \mathrm{~m} \mathrm{B.G.L.,} \mathrm{recovered} 100 \%$ clay, circulated and pulled out drilling column to the surface. Assembled $38.10 \mathrm{~cm}$ (15"Ø) bit, eight $16.51 \mathrm{~cm}$ $\left(16-1 / 2^{\prime \prime} \emptyset\right)$ drill collars: and $11.43 \mathrm{~cm}\left(4-1 / 2^{\prime \prime} \emptyset\right)$ drill pipe, inserted it to $661.88 \mathrm{~m} \mathrm{B.G.L}$. where light resistance was noted, circulated and inserted 
drilling column, circulating for intervals down to $954.88 \mathrm{~m} \mathrm{B.G.L.,} \mathrm{circulated}$ and pulled out column to the surface.

At 2:00 hours on 30 December 173 started running $29.84 \mathrm{~cm}(11-3 / 4 " \emptyset) \mathrm{N}-80$ Youngstown .B.T. $89.5 \mathrm{~kg} / \mathrm{m}$ (60 1b/foot) and $\mathrm{K}-55, \mathrm{NKK}$, B.T. $69.9 \mathrm{~kg} / \mathrm{m}$ (47 1b/foot) casing $694.12 \mathrm{~m} \mathrm{B.G.L.} \mathrm{where} \mathrm{resistance} \mathrm{was} \mathrm{observed,} \mathrm{worked} \mathrm{in}$ the casing, circulated and lowered to $699.70 \mathrm{~m} \mathrm{B.G.L.} \mathrm{where} \mathrm{strong} \mathrm{resistance}$ was observed, circulated, worked the casing with tensions of 63.6 tons, $(140,000 \mathrm{1b})$ without achieving positive results, in one 0.35 casing run tensions increased to 68.2 tons $(150,000 \mathrm{lb})$, decided to cement at this depth with 74.03 tons of cement type "G" modified $1: 1$ and $1: 2$ with diamix $\left(80.15 \mathrm{~m}^{3}\right.$ of cement grout). The excess cement came out to the surface, the operation was terminated at 15:20 hours on 30 December 173, and 18 hours were waited before pulling out the $29.85 \mathrm{~cm}\left(11-3 / 4^{\prime \prime} \emptyset\right)$ casing, excavated cellar, cleaned the settling pit at 12:00 hours on 31 December, suspended operations for the end of the year. On 2 January '74 cut 11-3/4" $\emptyset$ casing provisionally at the height of the preventer, inserted $26.99 \mathrm{~cm}\left(10-5 / 8^{\prime \prime} \emptyset\right)$ bit to $680.90 \mathrm{~m} \mathrm{B.G.L.} \mathrm{where} \mathrm{top} \mathrm{of}$ cement was loaded with 3 tons weight, pulled out drilling column, removed fifth preventer, welded flange with $2^{\prime \prime}$ opening to $11-3 / 4^{\prime \prime}$ casing, inspected top of cement in 11-3/4", 16" annular space finding it at $4.83 \mathrm{~m} \mathrm{B.G.L.,} \mathrm{removed} \mathrm{the}$ 2" line connected to the flange which covers the 11-3/4" casing considering the operations of the first stage terminated on 4 Jaunary 174. Disassembled H-35 equipment and transported it to the M-14 location. With personnel from the Mexico shop welded $29.85 \times 30.48 \mathrm{~cm}\left(11-3 / 4 \times 12^{\prime \prime}\right) \mathrm{S}-900,3000$ lb A.P.I. wellhead.

\section{SECOND STAGE}

HYDRAULIC TEST

On 4 February '74. the $H-40$ equipment was installed, assembled $26.98 \mathrm{~cm}$ $\left(10-5 / 8^{\prime \prime} \emptyset\right)$ bit, four $20.32 \mathrm{~cm}\left(8^{\prime \prime} \emptyset\right)$ drill collars, six $16.51 \mathrm{~cm}\left(6-1 / 2^{\prime \prime} \emptyset\right) \mathrm{dril1}$ collars and $11.43 \mathrm{~cm}\left(4-1 / 2^{\prime \prime} \emptyset\right)$ F.H. drill pipe, lowered it to $674.67 \mathrm{~m} \mathrm{B.G.L}$. where it reached cement plug inside the $29.84 \mathrm{~cm}\left(11-3 / 4^{\prime \prime} \emptyset\right)$ casing.

Tried hydraulic test on three occasions without luck due to leaks between the well head (11-3/4" $\times 12 ")$ and adapter spool as well as between the preventer rams, removed drilling column to the surface, tightened the well head preventer $\left(11-3 / 4 " x 12^{\prime \prime}\right)$ and the spool (12" $\left.\times 16^{\prime \prime}\right)$, inserted open $11.43 \mathrm{~cm}\left(4-1 / 2^{\prime \prime} \emptyset\right)$ F.H. drill pipe to $14.70 \mathrm{~cm}$ B.G.L., operated the preventer rams, increased 
pressure to $31.68 \mathrm{~kg} / \mathrm{cm}^{2}$ (450 psig), observed pressure loss, tightened the preventer rams again.

Increased pressure to $28.16 \mathrm{~kg} / \mathrm{cm}^{2}$ (400 psig) for 15 minutes without observing any pressure loss, opened preventer, pulled out open drill pipe, installed surface connections, inserted $26.98 \mathrm{~cm}\left(10-5 / 8^{\prime \prime} \emptyset\right)$ bit, four $20.32 \mathrm{~cm}$ (8"ø) drill collars, four $16.51 \mathrm{~cm}\left(6-1 / 2^{\prime \prime} \emptyset\right)$ drill collars and $11.43 \mathrm{~cm}$ (4-1/2"Ø) F.H. drill pipe, to $674.67 \mathrm{~m} \mathrm{B.G.L.} \mathrm{(top} \mathrm{of} \mathrm{cement).} \mathrm{On} \mathrm{two}$ occasions tried to carry out a test of the cementing job with negative results, tightened the connections, again carried out hydraulic test for 30 minutes with $56.32 \mathrm{~kg} / \mathrm{cm}^{2}$ (800 psig) satisfactorily.

DRILLING $26.99 \mathrm{~cm}\left(10-5 / 8^{\prime \prime} \emptyset\right)$ HOLE

At 18:45 hours on 8 February '74 with $26.98 \mathrm{~cm}\left(10-5 / 8^{\prime \prime} \emptyset\right)$ bit, four 20.32 cm ( $8^{\prime \prime \emptyset) ~ d r i l l ~ c o l l a r s, ~ f o u r ~} 16.51 \mathrm{~cm}\left(6-1 / 2^{\prime \prime} \emptyset\right)$ drill collars and $11.43 \mathrm{~cm}$ (4-1/2"ø) drilling pipe, inside $29.84 \mathrm{~cm}\left(11-3 / 4^{\prime \prime} \emptyset\right)$ casing drilled through cement plug, "Baker" flapper valve float collar and "Baker" flapper valve float shoe from $674.67 \mathrm{~m}$ to $699.70 \mathrm{~m} \mathrm{B.G.L.} \mathrm{cleaned} \mathrm{and} \mathrm{conditioned} 38.10 \mathrm{~cm}$ (15"ø) to $954.88 \mathrm{~m} \mathrm{B.G.L}$. where the bottom of the original hole was reached.

Resumed drilling through a formation of light gray, semi-compact coffeecolored shales, whitish sandstone and quartzitic material to $1062.20 \mathrm{~m} \mathrm{B.G.L}$. took inclination with TOTCO recorder, obtained a reading of $0^{\circ} 20^{\prime}$ at $1059.20 \mathrm{~m}$ B.G.L., continued drilling through the same formation to $1101.70 \mathrm{~m} \mathrm{B.G.L}$. where a loss of mud was observed in the $4.0 \mathrm{~m}^{3}$ pits, conditioned and increased the level of mud in pits with 35 sacks of bentonite, 1 sack of soda, 1 sack of milcon, 1 sack of unical, continued to drill to $1157.70 \mathrm{~m} \mathrm{B.G.L.} \mathrm{with} \mathrm{partial}$ loss of mud $\left(2 \mathrm{~m}^{3}\right)$ while adding sealing material to the mud, continued drilling in, semi-compact, dark slatty shale, and whitish sandstone, to $1173.70 \mathrm{~m} \mathrm{B.G.L.,}$ took inclination with TOTCO recorder obtaining a reading of $0^{\circ} 50^{\prime}$.

Continued drilling in the same formation, pulled out the drilling column because of the slow penetration rate. Assembled and inserted $26.98 \mathrm{~cm}$ $\left(10-5 / 8^{\prime \prime} \emptyset\right)$ bit, four $20.32 \mathrm{~cm}\left(8^{\prime \prime} \emptyset\right)$ drill collars, two $16.51 \mathrm{~cm}\left(6-1 / 2^{\prime \prime}\right) \mathrm{drill}$ collars and $11.43 \mathrm{~cm}\left(4-1 / 2^{\prime \prime}\right)$ drill pipe, drilling through dark gray shale, whitish sandstone to $1296.70 \mathrm{~m}$ B.G.L. took inclination with TOTCO recorder obtaining a reading of $2^{\circ} 30^{\prime}$ at $1290.70 \mathrm{~m}$ B.G.L., verified this reading by running the instrument again. 
With the same drilling column circulated at $1296.70 \mathrm{~m} \mathrm{B.G.L.} \mathrm{to} \mathrm{eliminate}$ sealing material. Pulled the tool out to the surface and once more inserted $26.98 \mathrm{~cm}\left(10-5 / 8^{\prime \prime} \emptyset\right)$ bit, two $16.51 \mathrm{~cm}\left(6-1 / 2^{\prime \prime} \emptyset\right)$ drill collars and $11.43 \mathrm{~cm}$ (4-1/2"ø) drill pipe flushing and conditioning the mud at intervals to the bottom (1296.70 m B.G.L.). Pulled drilling column out to the surface.

\section{TEMPERATURE RECORDINGS}

At 18:15 hours on 18 February 174 .

With personnel and mechanical equipment from C.F.E. ran three temperature logs (two from the surface to $1296.70 \mathrm{~m} \mathrm{B.G.L.,} \mathrm{one} \mathrm{from} 996.70$ to $1297.70 \mathrm{~m}$ B.G.L.).

Inserted $26.98\left(10-5 / 8^{\prime \prime} \emptyset\right)$ bit, two $16.51 \mathrm{~cm}\left(6-1 / 2^{\prime \prime} \emptyset\right)$ drill collars and $11.43 \mathrm{~cm}\left(4-1 / 2^{\prime \prime} \emptyset\right)$ F.H. drill pipe down to the shoe of the $29.84 \mathrm{~cm}\left(11-3 / 4^{\prime \prime} \emptyset\right)$ casing (600.70 m B.G.L.) where circulation was done at low pressure, lowered column to the bottom circulating at low pressure at intervals because of breakdown of the Schlumberger unit in El Centro, California, raised column to the shoe. Waited for news about the equipment mentioned till 17:30 hours on 19 February 174, confirmed arrival of the Schlumberger equipment, inserted bit down to the bottom, refrigerated with 50 blocks of ice, refrigerated the bend in the suction pit, pumped $35 \mathrm{~m}^{3}$ of mud at $10^{\circ} \mathrm{C}$ into the well, pulled out drilling column to the surface.

\section{GEOPHYSICAL LOGS}

With personnel and equipment from Schlumberger obtained dual induction log from 954.27 to $1299.70 \mathrm{~m} \mathrm{B.R.T.} \mathrm{(3130-4263'),} \mathrm{compensated} \mathrm{neutron} \mathrm{density} 10 \mathrm{~g}$ from 954.27 to $1301.22 \mathrm{~m} \mathrm{B.R.T.}\left(3130-4268^{\prime}\right)$, and compensated gamma density $10 \mathrm{~g}$ from 957.93 to $1301.22 \mathrm{~m} \mathrm{B.R.T.}\left(1342-4268^{\prime}\right)$.

\section{CEMENTING $19.36 \mathrm{~cm}(7-5 / 8 " \emptyset)$ CASING}

Inserted $26.98 \mathrm{~cm}\left(10-5 / 8^{\prime \prime} \emptyset\right)$ bit, two $16.51 \mathrm{~cm}\left(6-1 / 2^{\prime \prime} \emptyset\right) \mathrm{drill}$ collars and $11.43 \mathrm{~cm}\left(4-1 / 2^{\prime \prime} \emptyset\right)$ drill pipe to $1296.70 \mathrm{~m} \mathrm{B.G.L.} \mathrm{where} \mathrm{mud} \mathrm{and} \mathrm{hole} \mathrm{were}$ conditioned.

At 17:30 hours on 20 February 174 carried out preparations and started to

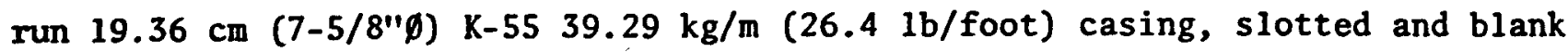
equipped with buttress threads, one Model $\mathrm{J}$ cement collar, one flapper valve collar, one perforated Baker flapper value collar, one blank Baker collar, one 
Davis guide shoe, four large metal baskets and 39 centralizers distributed in an alternative manner in the collars, the blank casing reached $1098.80 \mathrm{~m} \mathrm{B.G.L.}$ and the end of the slotted casing $1293.20 \mathrm{~m} \mathrm{B.G.L.}$

With personnel and mechanical equipment from B.J. the casing was cemented in two stages. At 4:45 hours on 21 February 174 cemented the first stage with $3.74 \mathrm{~m}^{3}$ of cement grout (3.83 tons, $\left.1: 1\right)$, at $11: 25$ hours cemented the second stage with $61.07 \mathrm{~m}^{3}$ of cement grout (55.45 tons of cement 1:2) observing excess cement reaching the surface, waited 18:00 hours for setting, placed $30.48 \times 20.48 \mathrm{~cm}\left(12^{\prime \prime} \times 1-1 / 2^{\prime \prime}\right)$ centralizers, but $19.36 \mathrm{~cm}\left(7-5 / 8^{\prime \prime} \emptyset\right)$ casing $0.15 \mathrm{~m}$ above the 11-3/4" $\emptyset$ casing, installed preventer and surface connections.

\section{HYDRAULIC TEST}

Inserted $16.51 \mathrm{~cm}\left(6-1 / 2^{\prime \prime} \emptyset\right)$ bit and $11.43 \mathrm{~cm}\left(4-1 / 2^{\prime \prime} \emptyset\right)$ drill pipe at $983.64 \mathrm{~m} \mathrm{B.G.L.,} \mathrm{where} \mathrm{it} \mathrm{reached} \mathrm{top} \mathrm{of} \mathrm{cement,} \mathrm{operated} \mathrm{annular} \mathrm{rams} \mathrm{on} \mathrm{the}$ blowout preventer, with $56 \mathrm{~kg} / \mathrm{cm}^{2}$ ( $800 \mathrm{psig}$ ), satisfactorily tested the casing and surface connections for 30 minutes with $68.25 \mathrm{~kg} / \mathrm{cm}^{2}$ (975 psig), the pressure increase was caused by the well heating up. Drilled through cement plug, "J" collar and float collar to $1085.04 \mathrm{~m} \mathrm{B.G.L.} \mathrm{Where} \mathrm{circulation} \mathrm{and}$ hydraulic test were carried out with $56 \mathrm{~kg} / \mathrm{cm}^{2}$ (800 psig) for 30 minutes increasing to $70.4 \mathrm{~kg} / \mathrm{cm}^{2}$ (1000 psig), continued drilling through cement plug, perforated collar, and blank collar, continued lowering tool flushing at intervals without encountering resistance to $1291.70 \mathrm{~m} \mathrm{B.G.L.,} \mathrm{cleaned} \mathrm{well,}$ pulled out and disassembled drilling column. Installed $30.48 \times 3032 \mathrm{~cm}$ (12" $x$ 8") S-3000 expansion spool, $2032 \mathrm{~cm}$ (8"Ø) S-900 master valve, hydraulic preventer and inserted $7.30 \mathrm{~cm}(2-7 / 8 " \emptyset)$. Internal Flush (I.F.), drill pipe circulating by stages, displaced mud by water to $1291.70 \mathrm{~m} \mathrm{B.G.L.} \mathrm{observing}$ that the water came out clean, pulled out breaking the 2-7/8" $\emptyset$ I.F. drill pipe, satisfactorily tested $8^{\prime \prime} \emptyset$ master valve with $42 \mathrm{~kg} / \mathrm{cm}^{2}$ (600 psig) for 15 minutes at 14:45 hours on 2 March, closed master valve considering the well completed.

Compiled

(signed)

Julio Francisco Martinez R.
Reviewed

(signed)

Engineer Rene de Leon Botello SUPERINTENDENT OF WELL DRILLING

Approved

(signed)

Engineer Bernardo Dominguez A. GENERAL SUPERINTENDENT 
SP-GAMMA RAY OVERLAYS WELL 14 


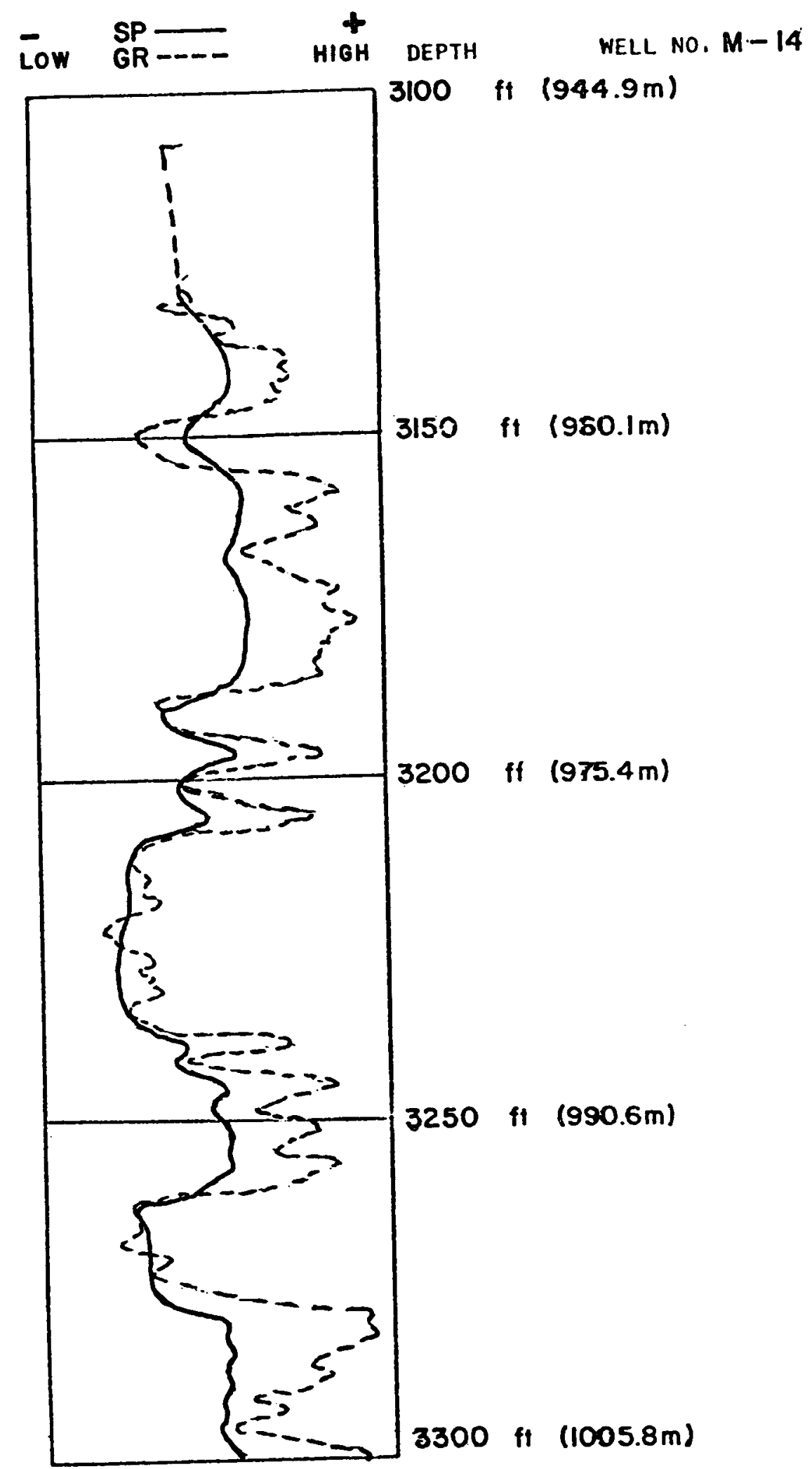

Fig. D-1. SP-Gamma Ray Overlay. 


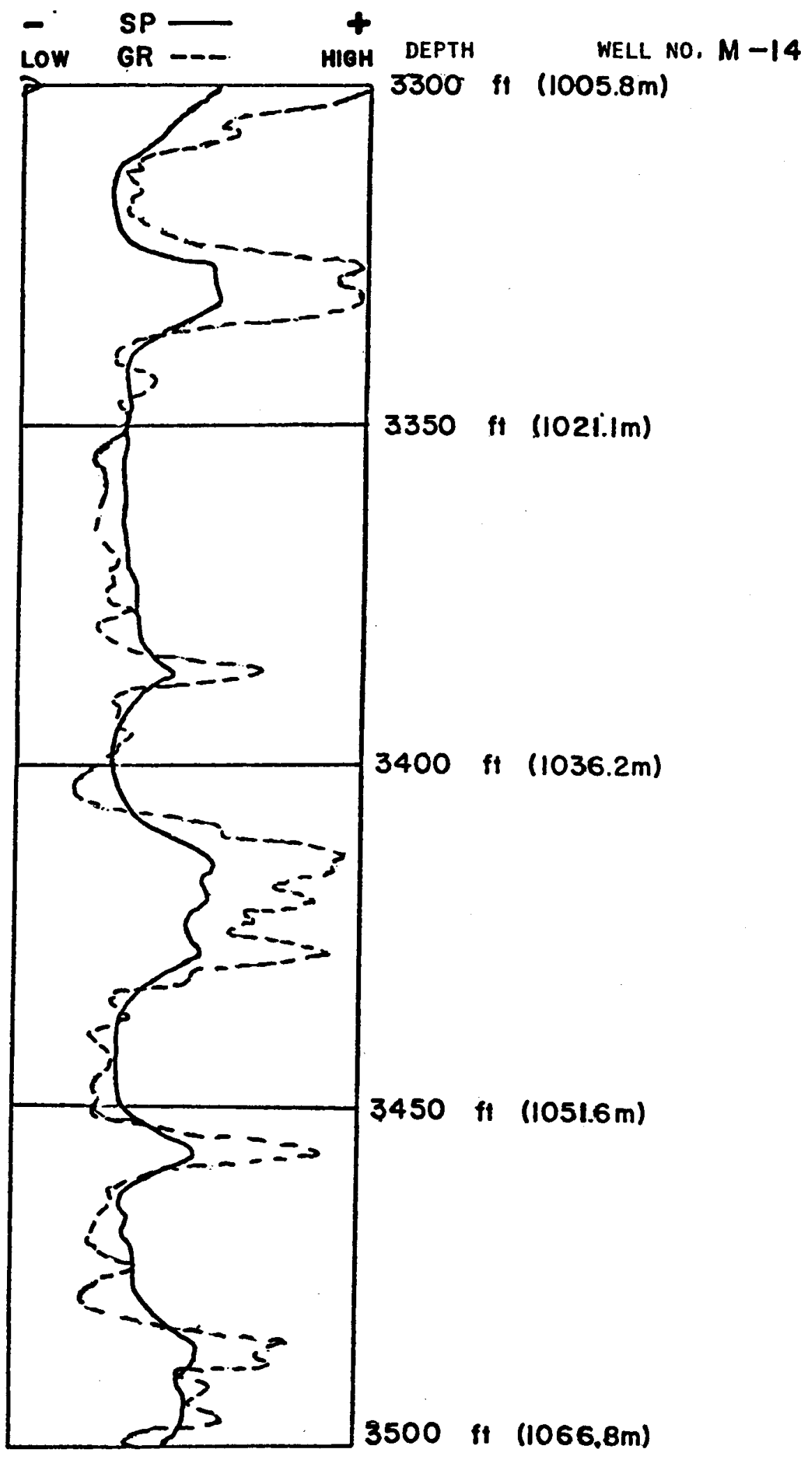

Fig. D-2. SP-Gamma Ray Overlay. 


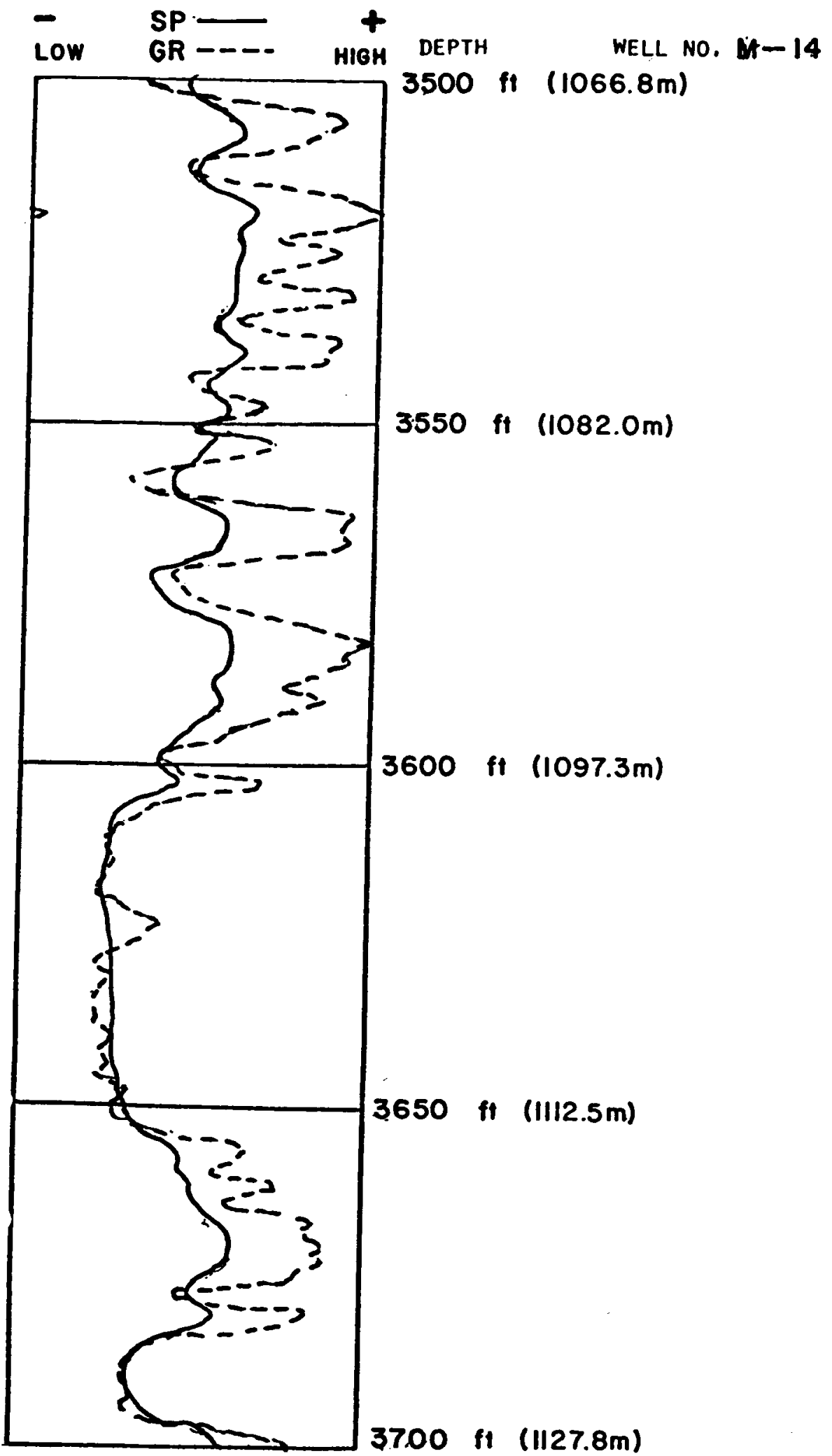

Fig. D-3. SP-Gamma Ray Overlay. 


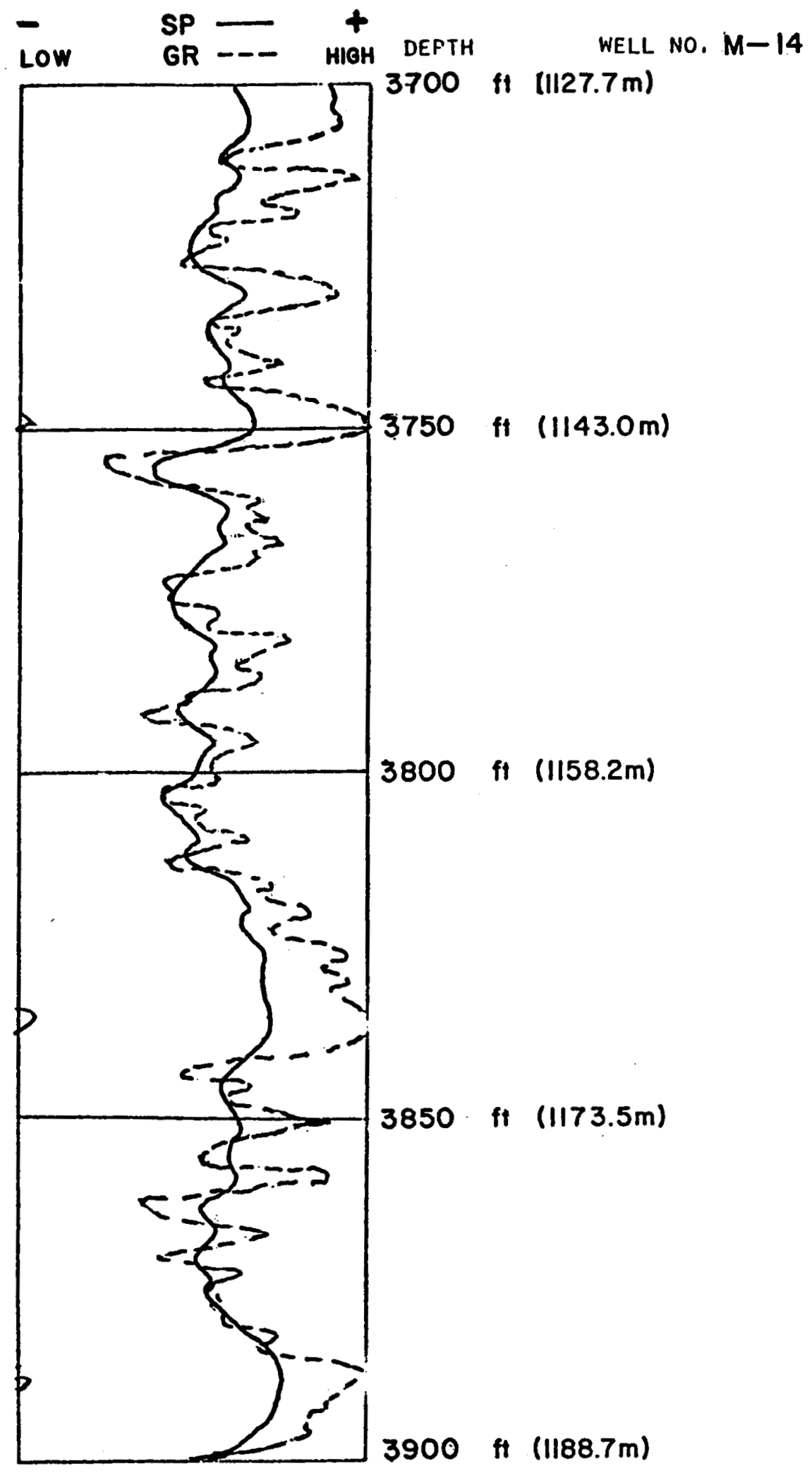

Fig. D-4. SP-Gamma Ray Overlay. 


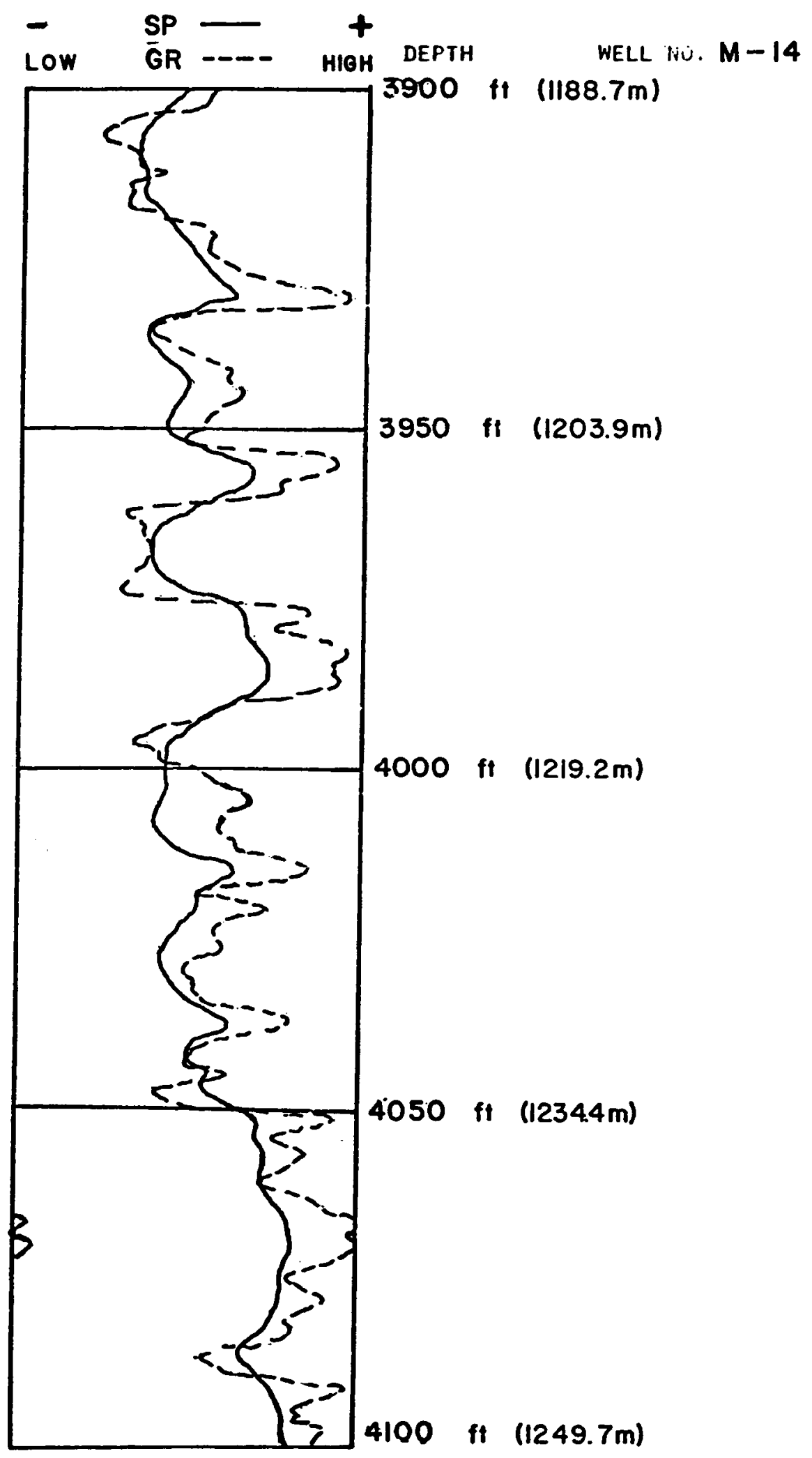

Fig. D-5. SP-Gamma Ray Overlay. 


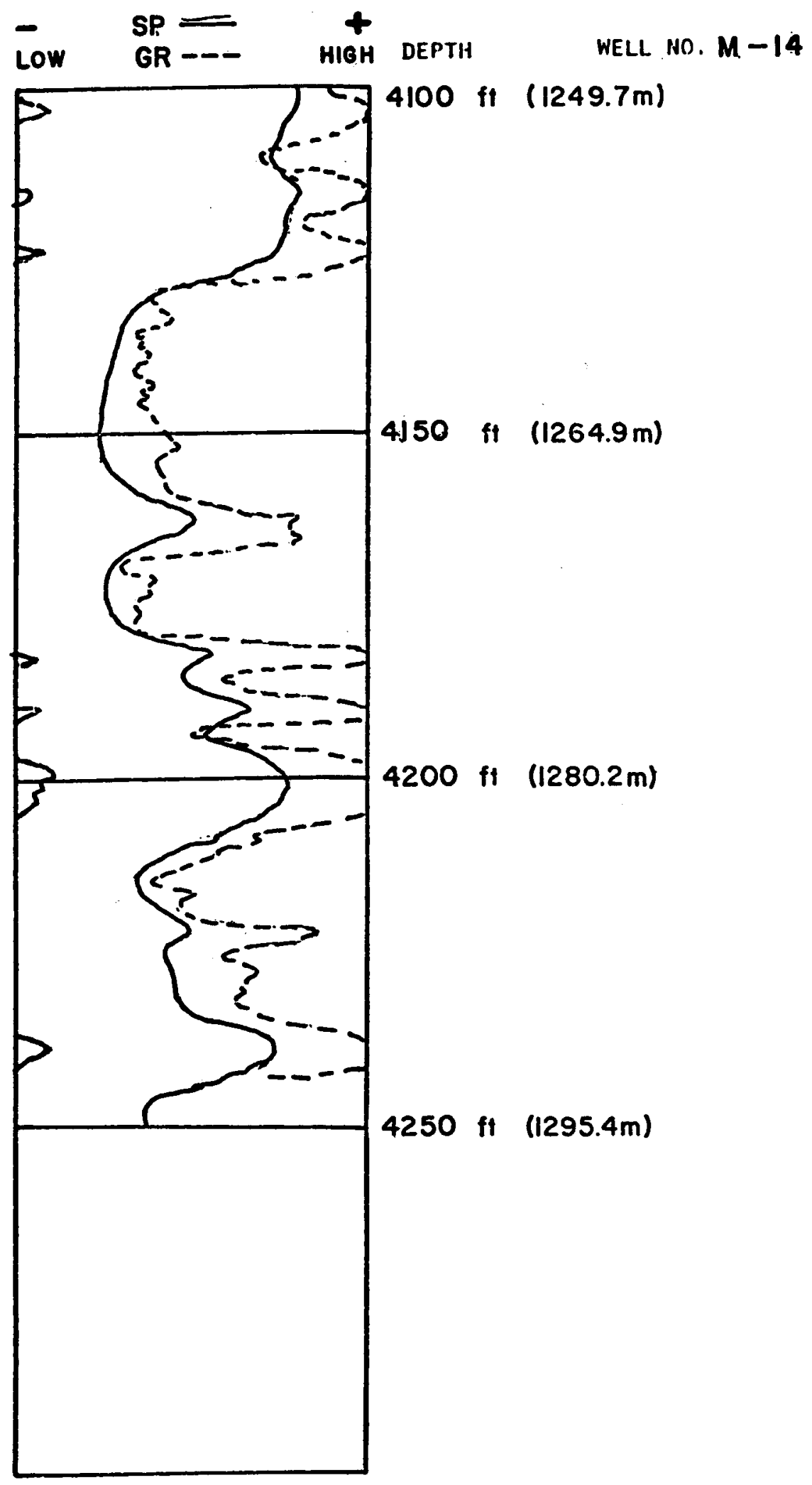

Fig. D-6. SP-Gamma Ray Overlay. 
WELL NUMBER $=14$

FIELD : CERRO PRIETO

RANGE : FROM 3338 TO 3334

COMPUTED RATA IS AS BELOW:

$\begin{array}{ll}\text { Tmf }= & 71.000 \\ \text { RHOmf }= & 1.100 \\ \text { PHIDC= } & 0.01 \\ \text { PHINC= } & 0.21 \\ \text { AN }= & 1.00 \\ \text { AM }=2.30 & \\ \text { FWCLY }= & 0.10 \\ \text { TDEEP }= & 225.0 \\ \text { RSH }= & 1.50\end{array}$

\begin{tabular}{|c|c|c|c|}
\hline $\begin{array}{l}\text { IEFTH } \\
3338 \\
3340\end{array}$ & $\begin{array}{l}\text { SP } \\
-68 . \\
-72 .\end{array}$ & $\begin{array}{ll}\text { GR PHId PHIn } \\
\text { 81. } 0.260 .19 \\
77.0 .23 & 0.18\end{array}$ & 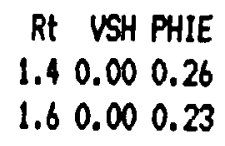 \\
\hline $\begin{array}{l}3342 \\
3344\end{array}$ & $\begin{array}{l}-74 . \\
-74 .\end{array}$ & $\begin{array}{lll}85 . & 0.24 & 0.20 \\
89 . & 0.31 & 0.20\end{array}$ & $\begin{array}{llll}1.3 & 0.00 & 0.24 \\
0.8 & 0.00 & 0.32\end{array}$ \\
\hline 346 & -74. & $80.0 .30 \quad 0.20$ & $0.90 .00 \quad 0.31$ \\
\hline $\begin{array}{l}3348 \\
3350\end{array}$ & $\begin{array}{l}-74 . \\
-77 .\end{array}$ & $\begin{array}{lll}79 . & 0.33 & 0.20 \\
81 . & 0.31 & 0.20\end{array}$ & $\begin{array}{llll}0.8 & 0.00 & 0.34 \\
0.8 & 0.00 & 0.32\end{array}$ \\
\hline 3352 & -75 & 78. 0.320 .20 & 0.70 .000 .33 \\
\hline $\begin{array}{l}3354 \\
3356\end{array}$ & $\begin{array}{l}-75 . \\
-77 .\end{array}$ & $\begin{array}{lll}\text { 72. } & 0.32 & 0.20 \\
\text { 73. } & 0.31 & 0.21\end{array}$ & $\begin{array}{llll}0.7 & 0.00 & 0.33 \\
0.7 & 0.00 & 0.32\end{array}$ \\
\hline 3358 & -75 & 75. 0.310 .21 & 0.70 .000 .32 \\
\hline $\begin{array}{l}3360 \\
3362\end{array}$ & $\begin{array}{l}-75 . \\
-75 .\end{array}$ & $\begin{array}{lll}\text { 75. } & 0.33 & 0.23 \\
73 . & 0.33 & 0.23\end{array}$ & $\begin{array}{llll}1.0 & 0.00 & 0.34 \\
0.9 & 0.00 & 0.34\end{array}$ \\
\hline 3364 & -75. & 73. 0.280 .21 & $\begin{array}{lll}-2.1 & 0.00 & 0.28\end{array}$ \\
\hline 3366 & -75. & 70. 0.290 .21 & $1.70 .00 \quad 0.29$ \\
\hline 3368 & -74. & 74. $0.25 \quad 0.20$ & $1.0 \quad 0.000 .25$ \\
\hline 3370 & -74. & 78. $0.26 \quad 0.20$ & 0.90 .000 .26 \\
\hline 3372 & -72 & 78. $0.27 \quad 0.20$ & $\begin{array}{lll}1.0 & 0.00 & 0.27\end{array}$ \\
\hline 3374 & -71. & 78. 0.260 .20 & $0.80 .00 \quad 0.26$ \\
\hline 3376 & -72 & 78. 0.270 .20 & $0.50 .00 \quad 0.27$ \\
\hline 3378 & -69. & 80.0 .240 .21 & $\begin{array}{lll}8.5 & 0.00 & 0.24\end{array}$ \\
\hline 3380 & -69. & 73. 0.250 .20 & $0.60 .00 \quad 0.25$ \\
\hline 3392 & -69. & 78. $0.26 \quad 0.20$ & 0.90 .000 .26 \\
\hline 3384 & -63. & 86.0 .230 .21 & $1.30 .00 \quad 0.23$ \\
\hline
\end{tabular}

R $\mathrm{f}=\quad 1.340$

\author{
TABLE 14-1'
}

FHITD USHGR RWSP PPMSP RWAX PPMAX RHAD PPMD SW RMF

$\begin{array}{llllllllllll}0.26 & 0.579 & 0.08 & 26596 . & 0.18 & 10938 . & 0.07 & 33370 . & 1.11 & 0.11 & 2.24\end{array}$

$\begin{array}{lllllllllll}0.23 & 0.368 & 0.08 & 28707 & 0.23 & 8674, & 0.06 & 40746 . & 1.17 & 0.08 & 2.69\end{array}$

$\begin{array}{lllllllllll}0.24 & 0.789 & 0.07 & 29769 . & 0.23 & 8666 . & 0.05 & 48035 . & 1.24 & 0.08 & 2.86\end{array}$

$\begin{array}{lllllllllll}0.32 & 1.000 & 0.07 & 29769 . & 0.22 & 9172 . & 0.05 & 42355 & 1.17 & 0.08 & 2.83\end{array}$

$\begin{array}{lllllllllllll}0.31 & 0.526 & 0.07 & 29769 & 0.33 & 5864 . & 0.06 & 40348 . & 1.14 & 0.05 & 3.03\end{array}$

$\begin{array}{lllllllllll}0.34 & 0.474 & 0.07 & 29657 . & 0.34 & 5691 . & 0.06 & 36610 & 1.10 & 0.05 & 3.03\end{array}$

$\begin{array}{lllllllllll}0.32 & 0.579 & 0.07 & 31241 . & 0.39 & 4930 . & 0.06 & 40557 . & 1.12 & 0.04 & 3.34\end{array}$

$\begin{array}{lllllllllll}0.33 & 0.421 & 0.07 & 30185 . & 0.35 & 5495 . & 0.05 & 42035 . & 1.16 & 0.05 & 3.13\end{array}$

$\begin{array}{lllllllllll}0.33 & 0.105 & 0.07 & 30185 . & 0.31 & 6203 . & 0.05 & 41834 & 1.16 & 0.06 & 3.08\end{array}$

$\begin{array}{lllllllllll}0.32 & 0.158 & 0.07 & 31120, & 0.32 & 5914 . & 0.05 & 50801 . & 1.24 & 0.05 & 3.27\end{array}$

$\begin{array}{lllllllllll}0.32 & 0.263 & 0.07 & 30070, & 0.28 & 7058 . & 0.05 & 48286 . & 1.23 & 0.06 & 3.02\end{array}$

$\begin{array}{lllllllllll}0.34 & 0.263 & 0.07 & 30070 . & 0.34 & 5695 . & 0.08 & 27762 . & 0.96 & 0.05 & 3.10\end{array}$

$\begin{array}{lllllllllll}0.34 & 0.158 & 0.07 & 30070 . & 0.29 & 6649 . & 0.07 & 29929 & 1.00 & 0.06 & 3.05\end{array}$

$\begin{array}{lllllllllll}0.28 & 0.158 & 0.07 & 30070 & -0.65 & 2855 . & -0.12 & 17932 . & 0.79 & 3.64 & -0.02\end{array}$

$\begin{array}{lllllllllll}0.29 & 0.000 & 0.07 & 29957 . & 0.43 & 4345 . & 0.10 & 21438 & 0.86 & 0.04 & 3.18\end{array}$

$\begin{array}{llllllllllll}0.25 & 0.211 & 0.07 & 29436 . & 0.22 & 8970 . & 0.04 & 52940 . & 1.30 & 0.08 & 2.82\end{array}$

$\begin{array}{lllllllllll}0.26 & 0.421 & 0.07 & 29436 . & 0.18 & 10917 & 0.04 & 57582 . & 1.35 & 0.10 & 2.70\end{array}$

$\begin{array}{lllllllllll}0.27 & 0.421 & 0.08 & 28394 . & 0.22 & 8970 . & 0.05 & 42986 . & 1.20 & 0.08 & 2.65\end{array}$

$\begin{array}{lllllllllll}0.26 & 0.421 & 0.08 & 27875 . & 0.19 & 10648 . & 0.04 & 61871 . & 1.42 & 0.10 & 2.47\end{array}$

$\begin{array}{lllllllllll}0.27 & 0.421 & 0.08 & 28291 . & 0.13 & 15629 & 0.03 & 96891 . & 1.72 & 0.16 & 2.25\end{array}$

$\begin{array}{lllllllllll}0.24 & 0.526 & 0.08 & 26745 . & 1.98 & 908 . & 0.32 & 5908 . & 0.50 & 0.01 & 2.89\end{array}$

$\begin{array}{llllllllllllllll}0.25 & 0.153 & 0.08 & 26745 . & 0.14 & 14965 . & 0.03 & 100101 . & 1.79 & 0.16 & 2.05\end{array}$

$\begin{array}{lllllllllll}0.26 & 0.421 & 0.08 & 26745, & 0.20 & 9942 . & 0.04 & 54004 . & 1.37 & 0.10 & 2.35\end{array}$

$\begin{array}{llllllllllllllllllllll}0.23 & 0.842 & 0.09 & 23694 & 0.23 & 8666 . & 0.04 & 53197 . & 1.43 & 0.09 & 2.00\end{array}$ 
WEL NMMBER $=14$

FIELD : CERRO PRIETO

RANGE : FROM 3334 TO 3384

TABLE 14-2'

CONPUTED DATA IS AS BELON: Raf 1.340

71.000

RHOnf $=1.100$

FHIDC $=0.01$

$\mathrm{PHINC}=\quad 0.21$

$A N=1.00$

$A M=2.30$

RHCLY $=0.10$

TDEEP $=500.0$

$R S H=1.50$

\begin{tabular}{|c|c|c|c|c|c|c|c|c|c|c|c|c|c|c|c|}
\hline $\begin{array}{l}\text { EPTH } \\
3334\end{array}$ & $\begin{array}{l}\text { SP } \\
41 .\end{array}$ & $\begin{array}{l}\text { GR } \\
134 .\end{array}$ & $\begin{array}{l}\text { Id PHIn } \\
100.24\end{array}$ & $\begin{array}{l}\text { Rt VSH PHIE } \\
0.70 .70 \quad 0.09\end{array}$ & $\begin{array}{l}\text { PHITD } \\
0.16\end{array}$ & $\begin{array}{l}\text { VSHGR } \\
1.000\end{array}$ & $\begin{array}{l}\text { RUSP } \\
0.10\end{array}$ & $\begin{array}{l}\text { PPNSP } \\
9477 .\end{array}$ & $\begin{array}{l}\text { RWAX } \\
0.12\end{array}$ & $\begin{array}{l}\text { PPNAX } \\
7264 .\end{array}$ & & $\begin{array}{l}\text { D PPND } \\
204775 .\end{array}$ & $\begin{array}{l}S W \\
1.84\end{array}$ & $\begin{array}{l}\text { Rif } \\
0.10\end{array}$ & 0.59 \\
\hline 3336 & 34. & 00. & 190.21 & 1.00 .100 .19 & 0.20 & 0.469 & 0.08 & 11451. & 0.11 & 7981. & 0.02 & 47998. & 1.76 & 0.10 & 0.85 \\
\hline 3338 & & & & & & 0.172 & 0.07 & 13622. & .03 & 10939. & .07 & 14037. & 1.01 & 0.14 & \\
\hline 3340 & 72. & 77 & & & & 0.109 & 0.07 & 14240. & 0.10 & 8674. & 0.06 & 17053. & 1.09 & 0.09 & \\
\hline 3342 & -74. & 85. & 0.20 & & 0.24 & 0.234 & 0.07 & 14548. & 0.10 & 8666. & 0.05 & 20021. & 1.16 & 0.09 & 1.42 \\
\hline 3344 & 74. & $\infty 0$ & & & & 0.297 & 0.07 & 14548. & .10 & 9172. & 0.05 & 17709. & .09 & 0.10 & 1.39 \\
\hline 334 & & & & & & 0.156 & 0.07 & 14548. & 0.15 & 5864. & 0.06 & 16891. & 1.07 & 0.06 & \\
\hline 3348 & 74 & & & & & 0.141 & 0.07 & 14548. & 0.16 & $56 \% 1$. & 0.06 & & 1.03 & 0.06 & .60 \\
\hline 3350 & -77. & & & & & 0.172 & 0.06 & 15007. & 0.18 & & .06 & & .06 & 0.05 & 1.76 \\
\hline 335 & -75. & 78 & & & & 0.125 & 0.06 & 14701. & 0.16 & 5495. & 0.05 & 1766 & .09 & 0.05 & 1.65 \\
\hline 335 & -75 & 72 & & & 0. & 0.031 & 0.06 & 14701. & 0.14 & 6203. & 0.05 & & .08 & 0.06 & 1.61 \\
\hline 3356 & -77 & 73. & & & 0.2 & 0.047 & 0.06 & 15007. & 0.15 & 4. & 0.05 & & .17 & 0.06 & 1.70 \\
\hline 3358 & -75. & & & & 32 & 0.078 & 0.06 & 14701. & 0.13 & 7058. & 0.05 & & .16 & 0.07 & 1.55 \\
\hline 3360 & -75 . & & & & .34 & 0.078 & 0.06 & 14701. & 0.16 & 5695. & 0.08 & & 0.91 & 0.06 & 1.64 \\
\hline 336 & -75. & 73 & & & 0.34 & 0.047 & 0.06 & 14701. & 0.13 & 6648. & 0.07 & 12743. & 0.94 & 0.07 & 1.58 \\
\hline 336 & -75. & 73 & & & 8 & 0.047 & 0.06 & 14701. & -0.30 & 2855. & -0.12 & 7735 & 0.74 & 2.17 & 0.02 \\
\hline 3366 & -75. & 70. & & & 0.29 & 0.000 & 0.06 & 14701. & 0.20 & 4345. & 0.10 & 9248. & 0.81 & 0.04 & 1.72 \\
\hline 3368 & -74. & 74 & .20 & 1.0 & 0.25 & 0.063 & 0.07 & 14548. & 0.10 & 8970 & 0.04 & 2232 & 1.21 & 0.10 & 1.40 \\
\hline 337 & -74 & & & 0.90 .000 .26 & 0.26 & 0.125 & 0.07 & 14548. & 0.08 & 1091 & 0.04 & & 1.26 & 0.13 & 1.28 \\
\hline 3372 & -72 & 78 & 270.20 & $\begin{array}{lll}1.0 & 0.00 & 0.27\end{array}$ & 0.27 & 0.125 & 0.07 & 14240. & 0.10 & 8970. & 0.05 & 182 & 1.12 & 0.10 & 1.33 \\
\hline 3374 & -71 & & 0.20 & 0.80 & 0.26 & 0.125 & 0.07 & 14036. & 0.09 & 1064 & 0.04 & 259 & 1.32 & 0.13 & 1.19 \\
\hline 3376 & -72 . & & 0.270 .20 & $0.5 \quad 0.00 \quad 0.27$ & 0.27 & 0.125 & 0.07 & 14240. & 0.06 & 15629. & 0.03 & & 1.60 & 0.25 & 0.87 \\
\hline 3378 & -69. & & 0.240 .21 & $8.50 .00 \quad 0.24$ & 0.24 & 0.156 & 0.07 & 13776. & 0.92 & 908. & 0.32 & 2646. & 0.46 & 0.01 & 1.73 \\
\hline 3380 & -69. & & & & 0.25 & 0.047 & 0.07 & 13776. & 0.06 & 14965. & 0.03 & 41765. & 1.65 & 0.25 & 0.80 \\
\hline 3382 & $-6 \%$. & & $0,200 .<0$ & $0.90 .00 \quad 0.26$ & 0. & 0.125 & 0.07 & 13776. & 0.09 & & 0.04 & 228 & 1.26 & 0.12 & 1.16 \\
\hline 3384 & -63. & & $0.23 \quad 0.21$ & $1.30 .00 \quad 0.23$ & 0.23 & 0.250 & 0.07 & 12846. & 0.10 & 8666. & 0.04 & & 1.29 & 0.10 & 1.05 \\
\hline
\end{tabular}


WELL MMBER $=14$

FIELD : CERRO PRIETO

RANGE : FROM 3333 TO 3384

COMPUTED DATA IS AS BELOW:

Tinf $=75.000$

$\mathrm{RHOmf}=1.100$

FHIDC $=0.01$

PHINC $=\quad 0.21$

AN $=\quad 1.00$

AN $=2.30$

RHCLY $=0.10$

TDEEP $=500.0$

$\mathrm{RSH}=1.50$

\begin{tabular}{rr} 
DEPTH & SP \\
3338 & -68 \\
3340 & -72 \\
3342 & -74 \\
3344 & -74 \\
3346 & -74 \\
3348 & -74 \\
3350 & -77 \\
3352 & -75 \\
3354 & -75 \\
3356 & -77 \\
3358 & -75 \\
3360 & -75 \\
3362 & -75 \\
3364 & -75 \\
3366 & -75 \\
3368 & -74 \\
3370 & -74 \\
3372 & -72 \\
3374 & -71 \\
3376 & -72 \\
3378 & -69 \\
3380 & -69 \\
3392 & -69 \\
3334 & -63 \\
\hline
\end{tabular}

TABLE 14-3'

TDEEP IS USED
Rmf $=$

0.370
SP GR PHId PHIn Rt USH PHIE $\begin{array}{lllllllll}-68 . & \text { 81. } 0.26 & 0.19 & 1.4 & 0.00 & 0.26\end{array}$

$\begin{array}{lllllll}-72 . & 77 . & 0.23 & 0.18 & 1.6 & 0.00 & 0.23\end{array}$

$\begin{array}{llllllll}74 . & 85 . & 0.24 & 0.20 & 1.3 & 0.00 & 0.24\end{array}$

$\begin{array}{lllllllllllllll}74 . & 89 . & 0.31 & 0.20 & 0.8 & 0.00 & 0.32\end{array}$

$\begin{array}{lllllll}74 . & 80 . & 0.30 & 0.20 & 0.9 & 0.00 & 0.31\end{array}$

$\begin{array}{llllllllllllllllll}-74 . & 79 . & 0.33 & 0.20 & 0.8 & 0.00 & 0.34\end{array}$

$\begin{array}{llllllll}-77 . & 81 . & 0.31 & 0.20 & 0.8 & 0.00 & 0.32\end{array}$

$\begin{array}{llllllllllllllllll}-75 . & 78 . & 0.32 & 0.20 & 0.7 & 0.00 & 0.33\end{array}$

$\begin{array}{llllllll}-75 . & 72 . & 0.32 & 0.20 & 0.7 & 0.00 & 0.33\end{array}$

$\begin{array}{llllllll}-77 . & 73 . & 0.31 & 0.21 & 0.7 & 0.00 & 0.32\end{array}$

$\begin{array}{lllllll}75 . & 75 . & 0.31 & 0.21 & 0.7 & 0.00 & 0.32\end{array}$

$\begin{array}{llllllll}-75 . & 75 . & 0.33 & 0.23 & 1.0 & 0.00 & 0.34\end{array}$

$\begin{array}{lllllllllll}-75 . & 73 . & 0.33 & 0.23 & 0.9 & 0.00 & 0.34\end{array}$

$\begin{array}{lllllllllllll}-75 . & 73 . & 0.28 & 0.21 & -2.1 & 0.00 & 0.28\end{array}$

$\begin{array}{lllllllllllll}-75 . & 70 . & 0.29 & 0.21 & 1.7 & 0.00 & 0.29\end{array}$

$\begin{array}{lllllllllllll}-74 . & 74 . & 0.25 & 0.20 & 1.0 & 0.00 & 0.25\end{array}$

$\begin{array}{lllllllllllllll}-74 . & 78 . & 0.26 & 0.20 & 0.9 & 0.00 & 0.26\end{array}$

$\begin{array}{llllllllllllllll}-72 . & 78 . & 0.27 & 0.20 & 1.0 & 0.00 & 0.27\end{array}$

$\begin{array}{llllllllllll}-71 . & 78 . & 0.26 & 0.20 & 0.8 & 0.00 & 0.26\end{array}$

$\begin{array}{llllllll}-72 . & 78 . & 0.27 & 0.20 & 0.5 & 0.00 & 0.27\end{array}$

$\begin{array}{lllllllllllllllll}-69 & 80 . & 0.24 & 0.21 & 8.5 & 0.00 & 0.24\end{array}$

$\begin{array}{lllllllllllllllll}-69 . & 73 . & 0.25 & 0.20 & 0.6 & 0.00 & 0.25\end{array}$

$\begin{array}{llllllllll}-69 & 78 . & 0.26 & 0.20 & 0.9 & 0.00 & 0.26\end{array}$
36. $0.23 \quad 0.21 \quad 1.3 \quad 0.00 \quad 0.23$
PHIT USHGR RWSP PPMSP RHAX PFWAX RWAD PPMD SW RTF

$\begin{array}{llllllllllll}0.26 & 0.579 & 0.04 & 22691 & 0.02 & 43050 . & 0.07 & 14037 & 0.80 & 0.14 & 1.06\end{array}$

$\begin{array}{lllllllllllll}0.23 & 0.368 & 0.04 & 23086 . & 0.03 & 33811 . & 0.06 & 17053 . & 0.87 & 0.09 & 1.35\end{array}$

$\begin{array}{llllllllllll}0.24 & 0.789 & 0.04 & 23277 . & 0.03 & 33779 . & 0.05 & 20021 . & 0.93 & 0.09 & 1.42\end{array}$

$\begin{array}{lllllllllllllll}0.32 & 1.000 & 0.04 & 23277 & 0.03 & 35832 & 0.05 & 17709, & 0.88 & 0.10 & 1.39\end{array}$

$\begin{array}{lllllllllll}0.31 & 0.526 & 0.04 & 23277 & 0.04 & 22482 & 0.06 & 0.06891 . & 0.86 & 0.06 & 1.59\end{array}$

$\begin{array}{llllllllllll}0.34 & 0.474 & 0.04 & 23277 & 0.05 & 21794 & 0.06 & 15436 . & 0.83 & 0.06 & 1.60\end{array}$

$\begin{array}{lllllllllllll}0.32 & 0.579 & 0.04 & 23555 . & 0.05 & 18764 . & 0.06 & 17057 . & 0.36 & 0.05 & 1.76\end{array}$

$\begin{array}{lllllllllll}0.33 & 0.421 & 0.04 & 23371 & 0.05 & 21012 . & 0.05 & 17662 . & 0.88 & 0.05 & 1.65\end{array}$

$\begin{array}{lllllllllll}0.33 & 0.105 & 0.04 & 23371 . & 0.04 & 23842 . & 0.05 & 17580 & 0.88 & 0.06 & 1.61\end{array}$

$\begin{array}{lllllllllll}0.32 & 0.158 & 0.04 & 23555 . & 0.04 & 22682 . & 0.05 & 21345 . & 0.96 & 0.06 & 1.70\end{array}$

$\begin{array}{llllllllllll}0.32 & 0.263 & 0.04 & 23371 . & 0.04 & 27273 . & 0.05 & 20315 & 0.94 & 0.07 & 1.55\end{array}$

$\begin{array}{llllllllllll}0.34 & 0.263 & 0.04 & 23371 . & 0.05 & 21810 . & 0.08 & 11843 . & 0.73 & 0.06 & 1.64\end{array}$

$\begin{array}{llllllllllll}0.34 & 0.158 & 0.04 & 23371 . & 0.04 & 25625 & 0.07 & 12743 . & 0.76 & 0.07 & 1.58\end{array}$

$\begin{array}{lllllllllll}0.28 & 0.158 & 0.04 & 23371 . & -0.09 & 10614 . & -0.12 & 7735 . & 0.60 & 2.17 & -0.02\end{array}$

$\begin{array}{lllllllllll}0.29 & 0.000 & 0.04 & 23371 . & 0.06 & 16449 . & 0.10 & 9248 . & 0.65 & 0.04 & 1.72\end{array}$

$\begin{array}{llllllllllll}0.25 & 0.211 & 0.04 & 23277 & 0.03 & 35012 . & 0.04 & 22327 . & 0.98 & 0.10 & 1.40\end{array}$

$\begin{array}{llllllllllll}0.26 & 0.421 & 0.04 & 23277 & 0.02 & 42963 & 0.04 & 24234 & 1.02 & 0.13 & 1.28\end{array}$

$\begin{array}{llllllllllll}0.27 & 0.421 & 0.04 & 23086 . & 0.03 & 35012 . & 0.05 & 18223 . & 0.90 & 0.10 & 1.33\end{array}$

$\begin{array}{llllllllllll}0.26 & 0.421 & 0.04 & 22999 . & 0.03 & 41859 & 0.04 & 25994 . & 1.06 & 0.13 & 1.19\end{array}$

$\begin{array}{llllllllllll}0.27 & 0.421 & 0.04 & 23086 . & 0.02 & 62421 . & 0.03 & 40454 . & 1.28 & 0.25 & 0.87\end{array}$

$\begin{array}{lllllllllll}0.24 & 0.526 & 0.04 & 22791 . & 0.27 & 3209 . & 0.32 & 2646 . & 0.37 & 0.01 & 1.73\end{array}$

$\begin{array}{llllllllllll}0.25 & 0.158 & 0.04 & 22791 . & 0.02 & 59666 . & 0.03 & 41765 . & 1.31 & 0.25 & 0.30\end{array}$

$\begin{array}{lllllllllll}0.26 & 0.421 & 0.04 & 22791 . & 0.03 & 38975 & 0.04 & 22872 . & 1.00 & 0.12 & 1.16\end{array}$

$\begin{array}{lllllllllll}0.23 & 0.842 & 0.04 & 22172 . & 0.03 & 33779 & 0.04 & 22539 & 1.01 & 0.10 & 1.05\end{array}$ 
WEL NUWER = 14

FIEID : CERPO PRIETO

RANCE : FRON 3338 TO 3384

COMPUTED DATA IS AS BELON:

RAHOnf $=1.100$

PHIDC $=0.01$

PHINC $=0.21$

$A N=$

$A=2.30$

RUCLY $=0.10$

TDEEP $=450.0$

RSH $=1.50$

\begin{tabular}{|c|c|c|c|}
\hline DEPTH & $\mathbf{S P}$ & GR. PHId PHIn & Rt USH PHIE \\
\hline 3339 & -68. & 81. 0.260 .19 & $\begin{array}{llll}1.4 & 0.00 & 0.26\end{array}$ \\
\hline 3340 & -72. & 77. $0.23 \quad 0.18$ & $\begin{array}{llll}1.6 & 0.00 & 0.23\end{array}$ \\
\hline 3342 & -74. & 85. $0.24 \cdot 0.20$ & $\begin{array}{llll}3 & 0.00 & 0.24\end{array}$ \\
\hline 3344 & -74. & 89.0 .310 .20 & $\begin{array}{llll}0.8 & 0.00 & 0.32\end{array}$ \\
\hline 3346 & -74. & $80.0 .30 \quad 0.20$ & $\begin{array}{llll}0.9 & 0.00 & 0.31\end{array}$ \\
\hline 3348 & -74. & 79. 0.330 .20 & 0.80 .000 . \\
\hline 3350 & -77 . & 81. 0.310 .20 & \\
\hline 3352 & -75 & 78. $0.32 \quad 0.20$ & $\begin{array}{llll}0.7 & 0.00 & 0.33\end{array}$ \\
\hline 3354 & -75. & 72. $0.32 \quad 0.20$ & 0.70 .000 \\
\hline 3356 & -77 & 73. 0.310 .21 & \\
\hline 3358 & -75 . & 75. 0.310 .21 & 0.70 .00 \\
\hline 3360 & -75. & 75. 0.330 .23 & 1.00 .00 \\
\hline 3362 & -75. & 73. 0.330 .23 & $0.90 .00 \quad 0.34$ \\
\hline 3364 & -75 . & 73. 0.280 .21 & -2.10 .000 .28 \\
\hline 3366 & -75. & $\begin{array}{lll}70 . & 0.29 & 0.21\end{array}$ & $1.70 .00 \quad 0.29$ \\
\hline 3368 & -74 & 74. 0.250 .20 & $\begin{array}{lll}1.0 & 0.00 & 0.25\end{array}$ \\
\hline 3370 & -74. & 78. $0.26 \quad 0.20$ & $0.9 \quad 0.00 \quad 0.26$ \\
\hline 3372 & -72. & 78. 0.270 .20 & 1.00 .000$. \\
\hline 3374 & -71. & 78. 0.260 .20 & 0.80 .000 .2 \\
\hline 3376 & -72 & 78. 0.270 .20 & 0.50 .000 .2 \\
\hline 3378 & -69. & 80. 0.240 .21 & 8.50 .000 \\
\hline 3380 & -69. & 73. 0.250 .20 & \\
\hline 3382 & -69. & 78. $0.26 \quad 0.20$ & 0.90 .000 \\
\hline 3384 & -63. & 86. $0.23 \quad 0.21$ & 1.30 .000 \\
\hline
\end{tabular}

TABLE 14-4'

TIEEP IS USED
PHITD VSHGR RUSP PPMSP RHAX PPMAX RHAD PPID SH RTF

$\begin{array}{lllllllllll}0.26 & 0.579 & 0.04 & 25877 & 0.02 & 48339 & 0.07 & 15728 . & 0.80 & 0.13 & 1.19\end{array}$ $\begin{array}{lllllllllll}0.23 & 0.368 & 0.04 & 26327 . & 0.03 & 37935 . & 0.06 & 19120 & 0.87 & 0.09 & 1.49\end{array}$ $\begin{array}{lllllllllll}0.24 & 0.789 & 0.04 & 26544, & 0.03 & 37898, & 0.05 & 22459 & 0.93 & 0.09 & 1.57\end{array}$ $\begin{array}{lllllllllll}0.32 & 1.000 & 0.04 & 26544 & 0.03 & 40210 & 0.05 & 19858 & 0.88 & 0.10 & 1.54\end{array}$ $\begin{array}{lllllllllll}0.31 & 0.526 & 0.04 & 26544 . & 0.04 & 25190 & 0.06 & 18937 . & 0.86 & 0.06 & 1.74\end{array}$ $\begin{array}{lllllllllll}0.34 & 0.474 & 0.04 & 26544, & 0.05 & 24416 . & 0.06 & 17301 . & 0.82 & 0.05 & 1.75\end{array}$ $\begin{array}{lllllllllll}0.32 & 0.579 & 0.04 & 26859 & 0.05 & 21011 & 0.06 & 19124 & 0.86 & 0.05 & 1.93\end{array}$ $\begin{array}{lllllllllll}0.33 & 0.421 & 0.04 & 26650 & 0.05 & 23538 . & 0.05 & 19805 & 0.87 & 0.05 & 1.81\end{array}$ $\begin{array}{lllllllllll}0.33 & 0.105 & 0.04 & 26650 & 0.04 & 26718 . & 0.05 & 19713 & 0.87 & 0.06 & 1.76\end{array}$ $\begin{array}{lllllllllll}0.32 & 0.159 & 0.04 & 26859 & 0.04 & 25414 & 0.05 & 23951 . & 0.95 & 0.06 & 1.87\end{array}$ $\begin{array}{lllllllllll}0.32 & 0.263 & 0.04 & 26650 & 0.04 & 30577 & 0.05 & 22790 & 0.93 & 0.07 & 1.71\end{array}$ $\begin{array}{lllllllllll}0.34 & 0.263 & 0.04 & 26650 & 0.05 & 24434 & 0.08 & 13261 . & 0.73 & 0.05 & 1.80\end{array}$ $\begin{array}{lllllllllll}0.34 & 0.158 & 0.04 & 26650 & 0.04 & 28724 & 0.07 & 14273 & 0.75 & 0.07 & 1.74\end{array}$ $\begin{array}{lllllllllll}0.28 & 0.158 & 0.04 & 26650 & -0.09 & 11862 . & -0.12 & 8648 . & 0.60 & 2.33 & -0.02\end{array}$ $\begin{array}{lllllllllllllllll}0.29 & 0.000 & 0.04 & 26650 & 0.06 & 18411 . & 0.10 & 10346 . & 0.65 & 0.04 & 1.88\end{array}$ $\begin{array}{lllllllllll}0.25 & 0.211 & 0.04 & 26544 & 0.03 & 39296 & 0.04 & 25056 & 0.97 & 0.09 & 1.55\end{array}$ $\begin{array}{lllllllllll}0.26 & 0.421 & 0.04 & 26544 & 0.02 & 48241 & 0.04 & 27204 & 1.01 & 0.12 & 1.43\end{array}$ $\begin{array}{lllllllllll}0.27 & 0.421 & 0.04 & 26327 & 0.03 & 39286 & 0.05 & 20436 & 0.89 & 0.10 & 1.47\end{array}$ $\begin{array}{lllllllllll}0.26 & 0.421 & 0.04 & 26217 & 0.03 & 46997 . & 0.04 & 29186 & 1.05 & 0.12 & 1.33\end{array}$ $\begin{array}{llllllllllll}0.27 & 0.421 & 0.04 & 26327 & 0.02 & 70176 . & 0.03 & 45490 & 1.28 & 0.23 & 1.03\end{array}$ $\begin{array}{lllllllllll}0.24 & 0.526 & 0.04 & 25992 . & 0.27 & 3572 . & 0.32 & 2947 & 0.36 & 0.01 & 1.86\end{array}$ $\begin{array}{lllllllllll}0.25 & 0.158 & 0.04 & 25992 . & 0.02 & 67068 & 0.03 & 46970 & 1.30 & 0.22 & 0.95\end{array}$ $\begin{array}{lllllllllll}0.26 & 0.421 & 0.04 & 25992 . & 0.03 & 43749 & 0.04 & 25670 & 0.99 & 0.11 & 1.30\end{array}$ $\begin{array}{lllllllllllllllllllllllllllll}0.23 & 0.842 & 0.04 & 25284 & 0.03 & 37898 & 0.04 & 25294 & 1.00 & 0.10 & 1.16\end{array}$ 
WELL NMHBER $=14$

FIE.D : CERPO PRIETO

RANGE : FROM 3606 TO 3652

COMPUTED DATA IS AS BE

$\begin{array}{lc}\text { Tnf }= & 71.000 \\ \text { RHOnF }= & 1.100 \\ \text { PHIDC }= & 0.01 \\ \text { PHINC }= & 0.21 \\ \text { AN }= & 1.00 \\ \text { AM }=2.30 & \\ \text { RWCLY }= & 0.10 \\ \text { TDEEP }= & 500.0\end{array}$

$R S H=1.50$

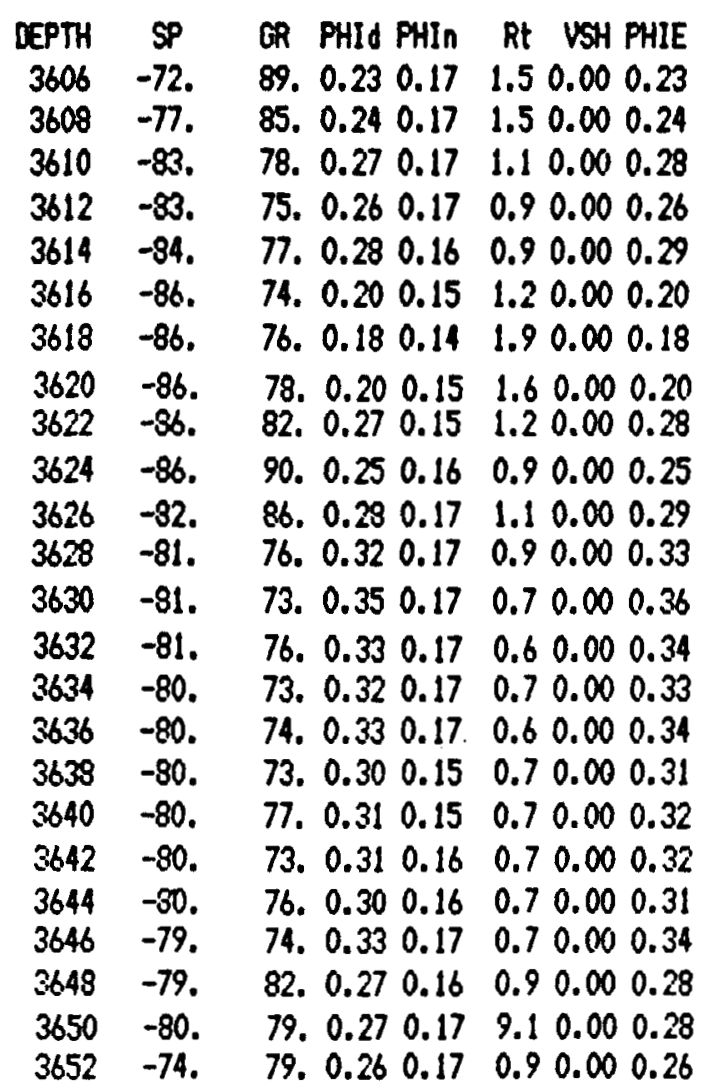

TABLE 14-5:

TDEEP IS USED
PHITD VSHGR RWSP PPMSP RHAX PPMAX RHAD PFMD SH RIFF

$\begin{array}{llllllllllll}0.23 & 0.941 & 0.07 & 14240 & 0.10 & 8766 . & 0.05 & 18687 . & 1.13 & 0.10 & 1.34\end{array}$ $\begin{array}{lllllllllll}0.24 & 0.706 & 0.06 & 15007 & 0.09 & 10042 . & 0.06 & 16057 . & 1.03 & 0.11 & 1.45\end{array}$ $\begin{array}{lllllllllll}0.28 & 0.294 & 0.06 & 15915 . & 0.13 & 6721 . & 0.06 & 16324 . & 1.01 & 0.06 & 1.89\end{array}$ $\begin{array}{lllllllllll}0.26 & 0.118 & 0.06 & 15915 . & 0.17 & 5224 . & 0.04 & 22927 . & 1.18 & 0.05 & 1.98\end{array}$ $\begin{array}{lllllllllll}0.29 & 0.235 & 0.06 & 16064 & 0.16 & 5449 . & 0.05 & 19080 . & 1.08 & 0.05 & 2.01\end{array}$ $\begin{array}{lllllllllll}0.20 & 0.059 & 0.06 & 16362 . & 0.14 & 6424 . & 0.03 & 32359 . & 1.36 & 0.06 & 2.04\end{array}$ $\begin{array}{lllllllllll}0.18 & 0.176 & 0.06 & 16362 . & 0.13 & 6623 . & 0.04 & 26884 & 1.25 & 0.06 & 2.03\end{array}$ $\begin{array}{lllllllllllll}0.20 & 0.294 & 0.06 & 16362 . & 0.07 & 13095 . & 0.04 & 24716 . & 1.21 & 0.15 & 1.63\end{array}$ $\begin{array}{lllllllllll}0.28 & 0.529 & 0.06 & 16362 . & 0.21 & 4222 . & 0.06 & 16052 . & 0.99 & 0.04 & 2.17\end{array}$ $\begin{array}{llllllllllllll}0.25 & 1.000 & 0.06 & 16362 . & 0.16 & 5449 . & 0.04 & 25692 & 1.23 & 0.05 & 2.10\end{array}$ $\begin{array}{lllllllllll}0.29 & 0.765 & 0.06 & 15765 . & 0.11 & 8344 . & 0.06 & 16211 . & 1.01 & 0.08 & 1.75\end{array}$ $\begin{array}{lllllllllll}0.33 & 0.176 & 0.06 & 15614 & 0.21 & 4222 . & 0.07 & 13644 . & 0.94 & 0.04 & 1.96\end{array}$ $\begin{array}{lllllllllll}0.36 & 0.000 & 0.06 & 15614 & 0.16 & 5646 . & 0.06 & 15298 . & 0.99 & 0.05 & 1.87\end{array}$ $\begin{array}{lllllllllll}0.34 & 0.176 & 0.06 & 15614 & 0.14 & 6190 & 0.05 & 18218 . & 1.07 & 0.06 & 1.84\end{array}$ $\begin{array}{lllllllllll}0.33 & 0.000 & 0.06 & 15463 . & 0.15 & 5750 . & 0.05 & 17976 . & 1.07 & 0.05 & 1.83\end{array}$ $\begin{array}{lllllllllll}0.34 & 0.059 & 0.06 & 15463 & 0.13 & 7115 . & 0.05 & 21304 . & 1.16 & 0.07 & 1.74\end{array}$ $\begin{array}{lllllllllll}0.31 & 0.000 & 0.06 & 15463 . & 0.14 & 6215 . & 0.05 & 20735 . & 1.14 & 0.06 & 1.80\end{array}$ $\begin{array}{lllllllllll}0.32 & 0.235 & 0.06 & 15463 . & 0.17 & 5070 . & 0.05 & 19448 . & 1.11 & 0.05 & 1.87\end{array}$ $\begin{array}{lllllllllll}0.32 & 0.000 & 0.06 & 15463 & 0.15 & 5795 . & 0.05 & 19284 . & 1.11 & 0.06 & 1.82\end{array}$ $\begin{array}{lllllllllll}0.31 & 0.176 & 0.06 & 15463 & 0.16 & 5495, & 0.05 & 20570, & 1.14 & 0.05 & 1.84\end{array}$ $\begin{array}{lllllllllll}0.34 & 0.059 & 0.06 & 15311 . & 0.10 & 8948 . & 0.06 & 17461 . & 1.06 & 0.09 & 1.59\end{array}$ $\begin{array}{lllllllllll}0.28 & 0.529 & 0.06 & 15311 . & 0.18 & 4796, & 0.05 & 21129 & 1.16 & 0.04 & 1.84\end{array}$ $\begin{array}{lllllllllll}0.28 & 0.353 & 0.06 & 15463 . & -0.03 & 39692 . & 0.47 & 1806 . & 0.36 & 4.11 & -0.14\end{array}$ $\begin{array}{lllllllllllll}0.26 & 0.353 & 0.07 & 14548 . & 0.16 & 5528 . & 0.04 & 24080 & 1.26 & 0.05 & 1.61\end{array}$ 


\section{FIELD : CERRO PRIETO}

RANGE : FROH . 3606 TO 3652

\section{COMPUTED DATA IS AS BELON: RMAf=}

\begin{tabular}{|c|c|c|c|c|c|c|c|c|c|c|c|c|c|c|c|}
\hline $\begin{array}{r}\text { DEPTH } \\
3606\end{array}$ & $\begin{array}{l}\text { SP } \\
-72 .\end{array}$ & 89. & $\begin{array}{l}\text { PHId PHIn } \\
0.23 \quad 0.17\end{array}$ & $\begin{array}{l}\text { Rt VSH PHIE } \\
1.50 .00 \quad 0.23\end{array}$ & $\begin{array}{l}\text { PHITD } \\
0.23\end{array}$ & $\begin{array}{l}\text { VSHGR } \\
0.941\end{array}$ & $\begin{array}{l}\text { RHSP } \\
0.07\end{array}$ & $\begin{array}{l}\text { PPNSP } \\
1565 \% .\end{array}$ & $\begin{array}{c}\text { RWAX } \\
0.12\end{array}$ & $\begin{array}{l}\text { FPMAX } \\
8766 .\end{array}$ & $\begin{array}{l}\text { RHA } \\
0.05\end{array}$ & $\begin{array}{l}\text { D PPKD } \\
20958 .\end{array}$ & $\begin{array}{l}S H \\
1.14\end{array}$ & $\begin{array}{l}\text { Fiv } \\
0.09\end{array}$ & 1.49 \\
\hline 3608 & -77 & 85. & $0.24 \quad 0.17$ & $1.50 .00 \quad 0.24$ & 0.24 & 0.706 & 0.06 & 16572. & 0.10 & 10042. & 0.06 & 18000. & 1.04 & 0.11 & 1.62 \\
\hline 3610 & -83. & 78 & 70.17 & & 0.28 & 0.294 & 0.06 & 17654. & 0.15 & 6721. & 0.06 & 18300. & 1.02 & 0.06 & $\infty$ \\
\hline 3612 & 33 & & & & 26 & 0.118 & 0.06 & 17654. & 0. & 522 & 0.04 & 2573 & 1. & 0.05 & .18 \\
\hline 3614 & 84. & 7 & 80.16 & 00.29 & 0.29 & 0.235 & 0.06 & 17832. & 0.18 & 5449. & 0.05 & 21401. & 1.09 & 0.05 & 2.22 \\
\hline 3616 & 86 & 74 & 15 & 20 & 0.20 & 0.059 & 0.06 & 18187. & 0.15 & 6424. & 0.03 & 36360. & 1.36 & 0.06 & .26 \\
\hline $3618+2$ & 36 & 76 & & & .18 & 0.176 & 0.06 & 18187. & 0.15 & 662 & 0.04 & 30189. & & 0.06 & 2. \\
\hline 3620 & -86. & 78 & 200.15 & 1.60 .000 .20 & 0.20 & 0.294 & 0.06 & 18187. & 0.08 & 13095. & 0.04 & 27747. & 1.21 & 0.14 & 1.86 \\
\hline 3622 & -86. & 82. & 270.15 & 0.28 & 0.28 & 0.529 & 0.06 & 18187. & 0.23 & 4222. & 0.06 & 17993. & 1.00 & 0.04 & 2.39 \\
\hline 3624 & -86. & 90. & .250 .16 & 0.90 .00 & 0.25 & 1.000 & 0.06 & 18187. & 0.18 & 5449. & 0.04 & 28846. & 1.23 & 0.05 & 2.32 \\
\hline 3626 & -82 . & 86. & 280.17 & 0.29 & 0.29 & 0.765 & 0.06 & 17475. & 0.12 & 8344. & 0.06 & 18173. & 1.02 & 0.08 & 1.95 \\
\hline 3628 & -81. & 76. & 20.17 & $0.9 \quad 0.00 \quad 0.33$ & 0.33 & 0.176 & 0.06 & 17295. & 0.23 & 4222. & 0.07 & 15286. & 0.95 & 0.04 & 2.15 \\
\hline 3630 & -81. & 73. & 0.17 & 0.70 .0 & 0.36 & 0.000 & 0.06 & 17295. & 0.17 & 5646. & 0.06 & 17146. & 1.00 & 0.05 & 2.06 \\
\hline 3632 & -81. & 76. & 330.17 & 0.60 .0 & 0.34 & 0.176 & 0.06 & 17295. & 0.16 & 6190. & 0.05 & 20431. & 1.08 & 0.06 & 2.03 \\
\hline 3634 & -80 & 73. & $0.32 \quad 0.17$ & $\begin{array}{llll}0.7 & 0.00 & 0.33\end{array}$ & 0.33 & 0.000 & 0.06 & 17115. & 0.17 & 5750. & 0.05 & 20158. & 1.08 & 0.05 & 2.01 \\
\hline 3636 & -80. & 74. & 0.330 .17 & $\begin{array}{llll}0.6 & 0.00 & 0.34\end{array}$ & 0.34 & 0.059 & 0.06 & 17115. & 0.14 & 7115. & 0.05 & 23904. & 1.16 & 0.07 & 1.93 \\
\hline 3638 & -80. & 73. & 0.300 .15 & $\begin{array}{llll}0.7 & 0.00 & 0.31\end{array}$ & 0.31 & 0.000 & 0.06 & 17115. & 0.16 & 6215 . & 0.05 & 23264 . & 1.15 & 0.06 & 1.98 \\
\hline 3640 & -80. & 77. & 0.310 .15 & $\begin{array}{llll}0.7 & 0.00 & 0.32\end{array}$ & 0.32 & 0.235 & 0.06 & 17115. & 0.19 & 5070. & 0.05 & 21815. & 1.12 & 0.05 & 2.05 \\
\hline 3642 & -80. & & 0.310 .16 & 0.70. & 0.32 & 0.000 & 0.06 & 17115. & 0.17 & & 0.05 & 21631 . & 1.11 & 0.05 & 2.01 \\
\hline 364 & - & & & & 0.31 & 0.176 & 0.06 & 171 & 0.18 & & 0.05 & 2307 & 1.14 & 0.05 & 2.03 \\
\hline 3646 & -79 & & 17 & 0.000 .34 & 0.34 & 0.059 & 0.06 & 16935. & 0.11 & 8. & 0.06 & 19579. & 1.07 & 0.09 & 1.77 \\
\hline $3648>>2>$ & -79 & 82. & .270 .16 & $\begin{array}{llll}0.9 & 0.00 & 0.28\end{array}$ & 0.28 & 0.529 & 0.06 & 16935. & 0.20 & & 0.05 & 2370 & 1.16 & 0.04 & 2.02 \\
\hline 50 & - & & & & $0.28>->$ & 0.353 & 0.06 & & -0.03 & 39692. & 0.47 & 2009. & 0.37 & 4.3 & -0.15 \\
\hline & -74. & & 0.200 & 0.90 .000 .26 & 0.26 & 0.353 & 0.07 & 10023. & 0.18 & 5528. & 0.04 & 27031 & 1.27 & 0.05 & 1.76 \\
\hline
\end{tabular}

TABLE 14-6'

TDEEP IS USED 1.340

$$
\begin{array}{lc}
\text { Tanf }= & 71.000 \\
\text { RHOanf }= & 1.100 \\
\text { PHIDC }= & 0.01 \\
\text { PHINC }= & 0.21 \\
\text { AN }= & 1.00 \\
\text { AM }=2.30 \\
\text { RHCLY }=0.10 \\
\text { TDEEP }=450.0 \\
\text { PCH }=1.50
\end{array}
$$$$
\begin{aligned}
& \text { TDEEP }= \\
& \text { RSH }=1.50
\end{aligned}
$$

PHITD VSHGR RLSP PPHISP RHAX FFMAX RHAD PPMD SH FWF $\begin{array}{lllllllllllll}0.28 & 0.294 & 0.06 & 17654, & 0.15 & 6721, & 0.06 & 18300 . & 1.02 & 0.06 & 2.09\end{array}$

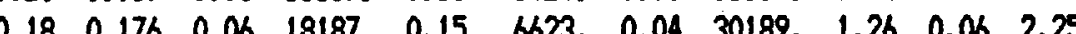
$\begin{array}{lllllllllll}0.20 & 0.294 & 0.06 & 18187 . & 0.08 & 13095 . & 0.04 & 27747 . & 1.21 & 0.14 & 1.86\end{array}$ $\begin{array}{lllllllllll}0.28 & 0.529 & 0.06 & 18187, & 0.23 & 4222 . & 0.06 & 17993 . & 1.00 & 0.04 & 2.39\end{array}$ $\begin{array}{lllllllllll}0.25 & 1.000 & 0.06 & 18187 . & 0.18 & 5449 . & 0.04 & 28846 . & 1.23 & 0.05 & 2.32\end{array}$ $\begin{array}{lllllllllll}0.29 & 0.765 & 0.06 & 17475 & 0.12 & 8344 . & 0.06 & 18173 . & 1.02 & 0.08 & 1.95\end{array}$ $\begin{array}{lllllllllll}0.33 & 0.176 & 0.06 & 17295 . & 0.23 & 4222 . & 0.07 & 15286 . & 0.95 & 0.04 & 2.15\end{array}$ $\begin{array}{lllllllllll}0.36 & 0.000 & 0.06 & 17295 & 0.17 & 5646 . & 0.06 & 17146 . & 1.00 & 0.05 & 2.06\end{array}$ $\begin{array}{lllllllllll}0.34 & 0.176 & 0.06 & 17295 . & 0.16 & 6190 . & 0.05 & 20431 . & 1.08 & 0.06 & 2.03\end{array}$ $\begin{array}{lllllllllll}0.33 & 0.000 & 0.06 & 17115 . & 0.17 & 5750 . & 0.05 & 20158 . & 1.08 & 0.05 & 2.01\end{array}$ $\begin{array}{lllllllllll}0.32 & 0.235 & 0.06 & 17115 & 0.19 & 5070 . & 0.05 & 21815 & 1.12 & 0.05 & 2.05\end{array}$ $\begin{array}{lllllllllll}0.32 & 0.000 & 0.06 & 17115 & 0.17 & 5795 . & 0.05 & 21631 & 1.11 & 0.05 & 2.01\end{array}$ $\begin{array}{lllllllllll}0.31 & 0.176 & 0.06 & 17115 . & 0.18 & 5495 . & 0.05 & 23078 . & 1.14 & 0.05 & 2.03\end{array}$ $0.28 \quad 0.529 \quad 0.06 \quad 16935,0.20 \quad 4796,0.05 \quad 23707.160 .16 \quad 0.04 \quad 2.02$ $\begin{array}{lllllllllll}0.26 & 0.353 & 0.07 & 16025 & 0.18 & 5528 & 0.04 & 27031 & 1.27 & 0.05 & 1.76\end{array}$ $\begin{array}{llllllllllllll}0.34 & 0.059 & 0.06 & 17115 . & 0.14 & 7115 . & 0.05 & 23904 . & 1.16 & 0.07 & 1.93\end{array}$ 
WELL NUMBER $=14$

FIELD : CERRO PRIETO

KANGE : FROM. 3606 TO 3652

Tnf $=75.000$

RHOaf $=1.100$

PHIDC $=0.01$

FHINC $=0.21$

AN $=$

AM $=2.30$

RHCLY $=0.10$

TDEEP $=500.0$

FSH $=1.50$

$\begin{aligned} \text { DEPTH } & .5 P \\ 3606 & -72 . \\ 3608 & -77 . \\ 3610 & -83 . \\ 3612 & -83 . \\ 3614 & -84 . \\ 3616 & -86 . \\ 3618 & -86 . \\ 3620 & -86 . \\ 3622 & -86 . \\ 3624 & -86 . \\ 3626 & -82 . \\ 3628 & -81 . \\ 3630 & -81 . \\ 3632 & -81 . \\ 3634 & -80 . \\ 3636 & -60 . \\ 3638 & -80 . \\ 3640 & -30 . \\ 3642 & -80 . \\ 3644 & -80 . \\ 3646 & -79 . \\ 3648 & -79 . \\ 3650 & -80 . \\ 3652 & -74 .\end{aligned}$

TABLE 14-7'

Raf $=$ 0.370
TDEEP IS USED
GR PHId PHIn RT USH PHIE

89. $0.23 \quad 0.17 \quad 1.50 .00 \quad 0.23$

85. $0.24 \quad 0.17 \quad 1.5 \quad 0.00 \quad 0.24$

78. $0.27 \quad 0.17 \quad 1.1 \quad 0.00 \quad 0.28$

$\begin{array}{llllll}75, & 0.26 & 0.17 & 0.9 & 0.00 & 0.26\end{array}$

77. $0.28 \quad 0.16 \quad 0.90 .000 .29$

74. $0.20 \quad 0.15 \quad 1.2 \quad 0.00 \quad 0.20$

76. $0.18 \quad 0.14 \quad 1.90 .00 \quad 0.18$

78. $0.20 \quad 0.15 \quad 1.6 \quad 0.00 \quad 0.20$

32. $0.27 \quad 0.15 \quad 1.2 \quad 0.00 \quad 0.28$

90. $0.25 \quad 0.16 \quad 0.90 .00 \quad 0.25$

86. $0.28 \quad 0.17 \quad 1.1 \quad 0.00 \quad 0.29$

76. $0.32 \quad 0.17 \quad 0.9 \quad 0.00 \quad 0.33$

$\begin{array}{llllllll}73 . & 0.35 & 0.17 & 0.7 & 0.00 & 0.36\end{array}$

76. $0.33 \quad 0.17 \quad 0.6 \quad 0.000 .34$

$\begin{array}{lllllll}\text { 73. } & 0.32 & 0.17 & 0.7 & 0.00 & 0.33\end{array}$

74. $0.33 \quad 0.17 \quad 0.6 \quad 0.00 \quad 0.34$

73. $0.300 .15 \quad 0.7 \quad 0.00 \quad 0.31$

77. $0.310 .15 \quad 0.7 \quad 0.00 \quad 0.32$

$\begin{array}{lllllllllllllllll}73 . & 0.31 & 0.16 & 0.7 & 0.00 & 0.32\end{array}$

76. $0.300 .16 \quad 0.70 .00 \quad 0.31$

74. $\begin{array}{llllll}0.33 & 0.17 & 0.7 & 0.00 & 0.34\end{array}$

82. $0.27 \quad 0.16 \quad 0.90 .00 \quad 0.28$

79. $0.27 \quad 0.17 \quad 9.10 .00 \quad 0.28$

79. $0.26 \quad 0.17 \quad 0.90 .00 \quad 0.26$
PHITD USHGR RUSP PPMSP RWAX PPMAX RHAD PPMD SW RTF

$\begin{array}{llllllllllll}0.23 & 0.941 & 0.04 & 23086 . & 0.03 & 34185 . & 0.05 & 18687 . & 0.91 & 0.10 & 1.34\end{array}$ $\begin{array}{lllllllllll}0.24 & 0.706 & 0.04 & 23555 . & 0.03 & 39381 . & 0.06 & 16057 . & 0.84 & 0.11 & 1.45\end{array}$ $\begin{array}{lllllllllll}0.28 & 0.294 & 0.04 & 24083 & 0.04 & 25920 . & 0.06 & 16324 . & 0.84 & 0.06 & 1.99\end{array}$ $\begin{array}{lllllllllll}0.26 & 0.113 & 0.04 & 24083 & 0.05 & 19930 & 0.04 & 22927 & 0.98 & 0.05 & 1.98\end{array}$ $\begin{array}{lllllllllll}0.29 & 0.235 & 0.04 & 24167 & 0.05 & 20829 & 0.05 & 19080 & 0.90 & 0.05 & 2.01\end{array}$ $\begin{array}{lllllllllll}0.20 & 0.059 & 0.04 & 24332 . & 0.04 & 24727 . & 0.03 & 32359 . & 1.14 & 0.06 & 2.04\end{array}$ $\begin{array}{lllllllllll}0.18 & 0.176 & 0.04 & 24332 . & 0.04 & 25523 . & 0.04 & 26884 . & 1.05 & 0.06 & 2.03\end{array}$ $\begin{array}{lllllllllll}0.20 & 0.294 & 0.04 & 24332 . & 0.02 & 51922 . & 0.04 & 24716 . & 1.01 & 0.15 & 1.63\end{array}$ $\begin{array}{lllllllllll}0.28 & 0.529 & 0.04 & 24332 . & 0.06 & 15962 . & 0.06 & 16052 . & 0.83 & 0.04 & 2.17\end{array}$ $\begin{array}{lllllllllll}0.25 & 1.000 & 0.04 & 24332 . & 0.05 & 20829 & 0.04 & 25692 . & 1.02 & 0.05 & 2.10\end{array}$ $\begin{array}{lllllllllll}0.29 & 0.765 & 0.04 & 23997, & 0.03 & 32470, & 0.06 & 16211 . & 0.84 & 0.08 & 1.75\end{array}$ $\begin{array}{lllllllllll}0.33 & 0.176 & 0.04 & 23911 . & 0.06 & 15962 . & 0.07 & 13644 . & 0.78 & 0.04 & 1.96\end{array}$ $\begin{array}{lllllllllll}0.36 & 0.000 & 0.04 & 23911 . & 0.05 & 21612 . & 0.06 & 15298 . & 0.82 & 0.05 & 1.87\end{array}$ $\begin{array}{lllllllllll}0.34 & 0.176 & 0.04 & 23911 . & 0.04 & 23789 . & 0.05 & 18218 . & 0.88 & 0.06 & 1.84\end{array}$ $\begin{array}{lllllllllll}0.33 & 0.000 & 0.04 & 23824 & 0.04 & 22028 . & 0.05 & 17976 . & 0.88 & 0.05 & 1.83\end{array}$ $\begin{array}{lllllllllll}0.34 & 0.059 & 0.04 & 23624 & 0.04 & 27505 & 0.05 & 21304, & 0.95 & 0.07 & 1.74\end{array}$ $\begin{array}{lllllllllll}0.31 & 0.000 & 0.04 & 23924 . & 0.04 & 23988 . & 0.05 & 20735 . & 0.94 & 0.06 & 1.80\end{array}$ $\begin{array}{lllllllllll}0.32 & 0.235 & 0.04 & 23824 & 0.05 & 19319 & 0.05 & 19448 . & 0.91 & 0.05 & 1.87\end{array}$ $\begin{array}{lllllllllll}0.32 & 0.000 & 0.04 & 23824 & 0.04 & 22206 . & 0.05 & 19284 . & 0.91 & 0.06 & 1.82\end{array}$ $\begin{array}{lllllllllll}0.31 & 0.176 & 0.04 & 23324 & 0.05 & 21012 . & 0.05 & 20570 . & 0.94 & 0.05 & 1.84\end{array}$ $\begin{array}{lllllllllll}0.34 & 0.059 & 0.04 & 23735 . & 0.03 & 34924 . & 0.06 & 17461 . & 0.87 & 0.09 & 1.59\end{array}$ $\begin{array}{lllllllllll}0.28 & 0.529 & 0.04 & 23735 . & 0.05 & 18232 . & 0.05 & 21129 & 0.95 & 0.04 & 1.84\end{array}$ $\begin{array}{lllllllllll}0.28 & 0.353 & 0.04 & 23324, & -0.01 & 164628 . & 0.47 & 1806 . & 0.30 & 4.11 & -0.14\end{array}$ $\begin{array}{llllllllllll}0.26 & 0.353 & 0.04 & 23277 . & 0.05 & 21142 . & 0.04 & 24090 . & 1.02 & 0.05 & 1.61\end{array}$ 
WELL NMTBER $=14$

FIELD : CERFO PRIETO

RANGE : FROM 3606 TO 3652

COMPUTED DATA IS AS BELON:

Timf $=\quad 75,000$

RHOnf $=1.100$

PHIOC $=0.01$

PHINC $=\quad 0.21$

AN $=\quad 1.00$

$A M=2.30$

RHCLY $=0.10$

TDEEP $=450.0$

RiSH $=1.50$

\begin{tabular}{|c|c|c|c|c|}
\hline DEPTH & 58 & GR & FHId FHIn & USH FHIE \\
\hline 3606 & -72 & 89. & $\begin{array}{lll}0.23 & 0.17\end{array}$ & 1.50 .000 .23 \\
\hline 3608 & -77 & 85. & 0.240 .17 & 1.50 .000 .24 \\
\hline 3610 & -83 & 78. & 0.270 .17 & 1.10 .000 .28 \\
\hline 3612 & -83. & 75. & $0.26 \quad 0.17$ & 0.90 .000 .26 \\
\hline 3614 & -34 & 77. & 0.280 .16 & 0.90 .000 .29 \\
\hline 3616 & -86 . & 74. & $0.20 \quad 0.15$ & 1.20 .000 .20 \\
\hline 3618 & -86. & 76. & 0.180 .14 & 1.90 .000 .18 \\
\hline 3620 & -86. & 78. & 0.200 .15 & 1.60 .000 .20 \\
\hline 3622 & -86 & 82. & $0.27 \quad 0.15$ & $\begin{array}{lll}1.2 & 0.00 & 0.28\end{array}$ \\
\hline 3624 & -86 & 90. & 0.250 .16 & $0.90 .00 \quad 0.25$ \\
\hline 3626 & -82. & 86. & $0.28 \quad 0.17$ & $1.10 .00 \quad 0.29$ \\
\hline 3628 & -81. & 76. & $0.32 \quad 0.17$ & $0.90 .00 \quad 0.33$ \\
\hline 3630 & -91. & 73. & $0.35 \quad 0.17$ & 0.70 .000 .36 \\
\hline 3632 & -81. & 76. & 0.330 .17 & $\begin{array}{lll}0.6 & 0.00 & 0.34\end{array}$ \\
\hline 3634 & -90 . & 73. & $0.32 \quad 0.17$ & $0.70 .00 \quad 0.33$ \\
\hline 3636 & -30 & 74. & 0.330 .17 & $0.6 \quad 0.00 \quad 0.34$ \\
\hline 3638 & -80 & 73. & 0.300 .15 & 0.70 .000 .31 \\
\hline 3640 & -80 & 77. & 0.310 .15 & 0.70 .000 .32 \\
\hline 3642 & -80 & 73. & 0.310 .16 & $0.70 .00 \quad 0.32$ \\
\hline 3644 & -80 & 76. & 0.300 .16 & 0.70 .000 .31 \\
\hline 3646 & -79 & 74. & 0.330 .17 & 0.70 .000 .34 \\
\hline 3648 & -79. & 82. & 0.270 .16 & 0.90 .000 .28 \\
\hline 3650 & -80. & & $\begin{array}{lll}0.27 & 0.17\end{array}$ & 9.10 .000 .2 \\
\hline & -74. & & $\begin{array}{lll}0.26 & 0.17\end{array}$ & 0.90 .000 \\
\hline
\end{tabular}

PHITD VSHGR RWGP PPMSP RIAX PPMAX RHAD PFMD SW RMF

$\begin{array}{lllllllllll}0.23 & 0.941 & 0.04 & 26327 . & 0.03 & 38356 & 0.05 & 20959 . & 0.90 & 0.09 & 1.49\end{array}$ $\begin{array}{llllllllllll}0.24 & 0.706 & 0.04 & 26859 . & 0.03 & 44207 . & 0.06 & 18000 . & 0.83 & 0.11 & 1.62\end{array}$ $\begin{array}{lllllllllllll}0.28 & 0.294 & 0.04 & 27454 . & 0.04 & 29056 & 0.06 & 18300 . & 0.83 & 0.06 & 2.09\end{array}$ $\begin{array}{llllllllllll}0.26 & 0.118 & 0.04 & 27454 . & 0.05 & 22321 . & 0.04 & 25731 . & 0.97 & 0.05 & 2.18\end{array}$ $\begin{array}{llllllllllll}0.29 & 0.235 & 0.04 & 27548 . & 0.05 & 23332 . & 0.05 & 21401 . & 0.89 & 0.05 & 2.22\end{array}$ $\begin{array}{lllllllllll}0.20 & 0.059 & 0.04 & 27733 . & 0.04 & 27713 . & 0.03 & 36360 . & 1.13 & 0.06 & 2.26\end{array}$ $\begin{array}{lllllllllll}0.18 & 0.176 & 0.04 & 27733 . & 0.04 & 28609 & 0.04 & 30189 . & 1.04 & 0.06 & 2.25\end{array}$ $\begin{array}{llllllllllll}0.20 & 0.294 & 0.04 & 27733 . & 0.02 & 58337 . & 0.04 & 27747 . & 1.00 & 0.14 & 1.86\end{array}$ $\begin{array}{lllllllllllll}0.28 & 0.529 & 0.04 & 27733 . & 0.06 & 17863 . & 0.06 & 17993 . & 0.82 & 0.04 & 2.39\end{array}$ $\begin{array}{lllllllllllllllll}0.25 & 1.000 & 0.04 & 27733 . & 0.05 & 23332 . & 0.04 & 23846 . & 1.02 & 0.05 & 2.32\end{array}$ $\begin{array}{lllllllllll}0.29 & 0.765 & 0.04 & 27358 . & 0.03 & 36425 . & 0.06 & 18173 . & 0.83 & 0.08 & 1.95\end{array}$ $\begin{array}{lllllllllll}0.33 & 0.176 & 0.04 & 27261 . & 0.06 & 17863 . & 0.07 & 15286 . & 0.77 & 0.04 & 2.15\end{array}$ $\begin{array}{llllllllllllllll}0.36 & 0.000 & 0.04 & 27261 . & 0.05 & 24212 . & 0.06 & 17146 . & 0.81 & 0.05 & 2.06\end{array}$ $\begin{array}{lllllllllll}0.34 & 0.176 & 0.04 & 27261 . & 0.04 & 26659 & 0.05 & 20431 . & 0.88 & 0.06 & 2.03\end{array}$ $\begin{array}{llllllllllll}0.33 & 0.000 & 0.04 & 27162 . & 0.04 & 24679, & 0.05 & 20158 . & 0.87 & 0.05 & 2.01\end{array}$ $\begin{array}{llllllllllll}0.34 & 0.059 & 0.04 & 27162 . & 0.04 & 30838 . & 0.05 & 23904 . & 0.94 & 0.07 & 1.93\end{array}$ $\begin{array}{llllllllllll}0.31 & 0.000 & 0.04 & 27162 . & 0.04 & 26770 . & 0.05 & 23264 . & 0.93 & 0.06 & 1.98\end{array}$ $\begin{array}{lllllllllll}0.32 & 0.235 & 0.04 & 27162 . & 0.05 & 21635 & 0.05 & 21815 & 0.91 & 0.05 & 2.05\end{array}$ $\begin{array}{llllllllllll}0.32 & 0.000 & 0.04 & 27162 . & 0.04 & 24880 . & 0.05 & 21631 . & 0.90 & 0.05 & 2.01\end{array}$ $\begin{array}{lllllllllll}0.31 & 0.176 & 0.04 & 27162 . & 0.05 & 23539 . & 0.05 & 23078 & 0.93 & 0.05 & 2.03\end{array}$ $\begin{array}{lllllllllllll}0.34 & 0.059 & 0.04 & 27062 . & 0.03 & 39188 . & 0.06 & 19579 . & 0.86 & 0.09 & 1.77\end{array}$ $\begin{array}{llllllllllll}0.23 & 0.529 & 0.04 & 27062 . & 0.05 & 20414 . & 0.05 & 23707 . & 0.94 & 0.04 & 2.02\end{array}$ $\begin{array}{lllllllllll}0.28 & 0.353 & 0.04 & 27162 . & -0.01 & 185658 . & 0.47 & 2009 . & 0.30 & 4.30 & -0.15\end{array}$ $\begin{array}{llllllllllllllllll}0.26 & 0.353 & 0.04 & 26544 & 0.05 & 23684 & 0.04 & 27031 & 1.01 & 0.05 & 1.76\end{array}$ 
DRILLING REPORT ON WELL M-27

LOCATION:

The calculation of the coordinates uses as origin the coordinates for the center of Unit No. 1 of the Cerro Prieto Geothermal Power Plant; coordinates are referred to the rehabilitation system of the Irrigation District of the Department of Hydraulic Resources.

$$
\begin{gathered}
X=-16915.15 \mathrm{~m}\left(55495.2^{\prime}\right) \\
Y=-2028.51 \mathrm{~m}\left(6655.1^{\prime}\right) \\
\text { Ground elevation (missing) } \\
\text { Rotary table elevation } 3.35 \mathrm{~m}\left(11.0^{\prime}\right)
\end{gathered}
$$

The well is located approximately $200.0 \mathrm{~m}\left(656.2^{\prime}\right)$ southwest of well $M-21,200.0 \mathrm{~m}\left(656.2^{\prime}\right)$ northeast of well M-31, and $130.0 \mathrm{~m}$ (426.5') northeast of well $\mathrm{M}-8$.

DRILLING $50.8 \mathrm{~cm}\left(20^{\prime \prime} \emptyset\right)$ HOLE

The drilling was started at 23:15 hours on February 10, 1973, drilling with $37.5 \mathrm{~cm}\left(14-3 / 4^{\prime \prime} \emptyset\right)$ bit and dri11 string to a depth of $270.65 \mathrm{mbg} 1$ $\left(887.9^{\prime}\right)$.

Pulled bit and drill string out to the surface.

Ran in $50.8 \mathrm{~cm}\left(20^{\prime \prime} \emptyset\right)$ hole opener followed by drill string, opened up the hole down to a depth of $270.65 \mathrm{mbg} 1$ (887.9')

Continued mud and hole, pulled drill string out to the surface.

\section{CEMENTING $40.6 \mathrm{~cm}$ (16"Ø) CASING}

Prepared and ran in $40.6 \mathrm{~cm}$ (16"Ø) grade $\mathrm{H}-4096.7 \mathrm{~kg} / \mathrm{m}(65 \mathrm{lb} / \mathrm{ft})$ round thread casing down to $265.65 \mathrm{mbgl}\left(871.5^{\prime}\right)$, equipped with float shoe, retention collar, 18 centralizers, and two hammer-lock stop rings.

With equipment and personnel from the Byron Jackson Company, cemented the casing with $45800 \mathrm{~kg}(100970.7 \mathrm{lb})$ of type G cement modified $1: 1$; the cement came out to the surface.

After the cement had set, removed surface connections, cut $40.6 \mathrm{~cm}$

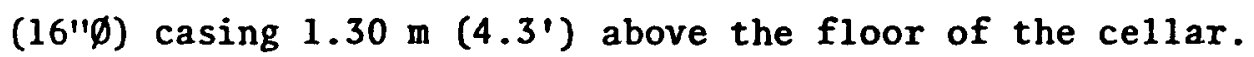

Welded $40.6 \mathrm{~cm}$ (16" $\emptyset$ ) well-head to the casing and allowed the weld to cool. 


\section{HYDRAULIC TEST}

Ran in $38.1 \mathrm{~cm}\left(15^{\prime \prime \emptyset) ~ b i t, ~ e i g h t ~} 16.5 \mathrm{~cm}\left(6-1 / 2^{\prime \prime} \emptyset\right)\right.$ drill collars, and drill string to $240.62 \mathrm{mbgl}\left(789.4^{\prime}\right)$; reached the top of the cement.

Closed blowout preventer, satisfactorily tested casing, cementing job, and surface connections with $42 \mathrm{~kg} / \mathrm{cm}^{2}$ (600 psig).

\section{DRILLING $38.1 \mathrm{~cm}\left(15^{\prime \prime} \emptyset\right)$ HOLE}

With $38.1 \mathrm{~cm}\left(15^{\prime \prime} \emptyset\right)$ bit, drilled through cement plug, collar, and casing shoe. Continued drilling to a depth of $896.65 \mathrm{mbgl}$ (2941.7').

Continued mud and hole, pulled drill string out to the surface.

\section{ELECTRICAL LOGS}

With equipment and personnel from the Schlumberger Company, took induction $\log$ from 268.9 to $901.5 \mathrm{mbrt}$ ( $882^{\prime}$ ' to $2957^{\prime}$ ), microlog from 269.2 to $901.2 \mathrm{mbrt}\left(883^{\prime}\right.$ to $\left.2956^{\prime}\right)$.

\section{CEMENTING $29.9 \mathrm{~cm}(11-3 / 4 " \emptyset)$ CASING}

Prepared and ran in $29.9 \mathrm{~cm}\left(11-3 / 4^{\prime \prime} \emptyset\right)$ grade $\mathrm{K}-5589.3 \mathrm{~kg} / \mathrm{m}(60 \mathrm{lb} / \mathrm{ft})$ and $70 \mathrm{~kg} / \mathrm{m}(47 \mathrm{lb} / \mathrm{ft})$ buttress thread casing down to $890.08 \mathrm{mbgl}\left(2920.2^{\prime}\right)$. It was equipped with a float shoe, a float collar, and 38 centralizers.

With equipment and personnel from the Byron Jackson Company, cemented the $29.9 \mathrm{~cm}\left(11-3 / 4^{\prime \prime} \emptyset\right)$ casing with $42.8 \mathrm{~m}^{3}$ (1511.4 $\left.\mathrm{ft}^{3}\right)$ of cement grout $1: 2$ and $14.1 \mathrm{~m}^{3}$ ( $497.9 \mathrm{ft}^{3}$ ) in the proportion $1: 1$. The cement came out to the surface.

After the cement had set, removed blowout preventer and surface connections.

INSTALLING $29.9 \mathrm{~cm}\left(11-3 / 4^{\prime \prime} \emptyset\right)$ WELL-HEAD

With equipment and personnel from the Perfesa Company, cut $40.6 \mathrm{~cm}$ (16"Ø) and $29.9 \mathrm{~cm}\left(11-3 / 4^{\prime \prime} \emptyset\right)$ casings at 1.20 and $1.70 \mathrm{~m}\left(3.94^{\prime}\right.$ and $\left.5.58^{\prime}\right)$, respectively, above the floor of the cellar.

Welded $29.9 \mathrm{~cm}\left(11-3 / 4^{\prime \prime} \emptyset\right)$ by $30.5 \mathrm{~cm}\left(12^{\prime \prime} \emptyset\right) \mathrm{S}-900,3000$ API well-head to the casing and allowed it to cool.

Installed adapter spool, blowout preventer, and surface connections. 
HYDRAULIC TEST

Ran in $27.0 \mathrm{~cm}\left(10-5 / 8^{\prime \prime} \emptyset\right)$ bit followed by four $20.3 \mathrm{~cm}\left(8^{\prime \prime} \emptyset\right)$ and eight $16.5 \mathrm{~cm}\left(6-1 / 2^{\prime \prime} \emptyset\right)$ drill collars and $11.4 \mathrm{~cm}\left(4-1 / 2^{\prime \prime} \emptyset\right)$ fh drill string down to $645.83 \mathrm{mbgl}\left(2118.9^{\prime}\right)$, where it reached the top of the cement. Drilled through the cement plug down to a depth of $876.65 \mathrm{mbg} 1$ (2876.1').

Closed blowout preventer, satisfactorily tested casing, cementing job, and surface connections with a pressure of $56 \mathrm{~kg} / \mathrm{cm}^{2}(800 \mathrm{psig})$ for $30 \mathrm{~min}$. Drilled through collar and shoe, and drilled down to $896.65 \mathrm{mbg} 1$ $\left(2941.7^{\prime}\right)$.

DRILLING $27.0 \mathrm{~cm}\left(10-5 / 8^{\prime \prime} \emptyset\right)$ HOLE

With $27.0 \mathrm{~cm}\left(10-5 / 8^{\prime \prime} \emptyset\right)$ bit and drill string, continued drilling to a depth of $946.15 \mathrm{mbg} 1$ (3104.1').

Pulled bit and drill string out to the surface.

Removed blowout preventer and surface connections.

Tested $29.9 \mathrm{~cm}$ (11-3/4" Ø) well-head, observed a pressure drop due to a defect in the well-head weld.

\section{INSTALLING $29.9 \mathrm{~cm}\left(11-3 / 4^{\prime \prime \emptyset) ~ W E L L-H E A D ~}\right.$}

With equipment and personnel from Timex, cut $29.9 \mathrm{~cm}\left(11-3 / 4^{\prime \prime} \emptyset\right)$ casing $1.575 \mathrm{~m}$ (5.17') above the floor of the cellar and again welded the well thead with inside and outside bead.

X-RAY LOG

With equipment and personnel from the Magna Flux Company, obtained $x$-ray $\log$ at the well-head weld, detecting a fault in this weld.

Rewelded the well-head and tested it satisfactorily with a pressure of $70 \mathrm{~kg} / \mathrm{cm}^{2}$ (1000 psig) for $30 \mathrm{~min}$.

DRILLING $27.0 \mathrm{~cm}\left(10-5 / 8^{\prime \prime} \emptyset\right)$ HOLE

Installed blowout preventer and surface connections.

Ran in $27.0 \mathrm{~cm}\left(10-5 / 8^{\prime \prime} \emptyset\right)$ bit and drill string to the bottom, continued drilling to a depth of $1296.65 \mathrm{mbgl}$ (4254.0').

Conditioned mud and hole, added 74 blocks of ice [9250 kg (20 $392.61 \mathrm{~b})]$ to the mud to refrigerate the well. 
Pulled the bit and drill string out to the surface.

LOGS

With equipment and personnel from the Schlumberger Company, took density $\log$ from 894.2 to $1300.0 \mathrm{mbrt}$ (2933' to $4267^{\prime}$ '), neutron $\log$ from 894.2 to $1300.9 \mathrm{mbrt}$ (2933' to $4267^{\prime}$ ), dual-induction $\log$ from 894.2 to $1299.1 \mathrm{mbrt}$ (2933' to $4261^{\prime}$ ), and cementing $10 \mathrm{~g}$ from 0 to $894.2 \mathrm{mbrt}$ ( 0 ' to $2933^{\prime}$ ).

With the cementing $\log$ it was observed that the zone 12.80 to 194.65 mbrt (42.0' to $638.6^{\prime}$ ') was canalized.

THE FOLLOWING DEVIATIONS WERE OBTAINED DURING THE DRILLING

$\begin{array}{rc}\frac{\text { Depth }}{296.65 \mathrm{mbg} 1\left(973.2^{\prime}\right)} & \frac{\text { Deviation }}{0^{\circ} 20^{\prime}} \\ 600.65 \mathrm{mbg} 1\left(1970.6^{\prime}\right) & 0^{\circ} 15^{\prime} \\ 796.65 \mathrm{mbg} 1\left(2613.6^{\prime}\right) & 0^{\circ} 20^{\prime} \\ 923.65 \mathrm{mbg} 1\left(3030.3^{\prime}\right) & 0^{\circ} 10^{\prime} \\ 933.65 \mathrm{mbg} 1\left(3063.1^{\prime}\right) & 0^{\circ} 40^{\prime} \\ 1186.65 \mathrm{mbg} 1\left(3893.2^{\prime}\right) & 0^{\circ} 00^{\prime}\end{array}$

CEMENTING $19.4 \mathrm{~cm}\left(7-5 / 8^{\prime \prime} \emptyset\right)$ CASING

Prepared and ran in $19.4 \mathrm{~cm}\left(7-5 / 8^{\prime \prime} \emptyset\right)$ grade $\mathrm{K}-55$ and $\mathrm{J}-5539.3 \mathrm{~kg} / \mathrm{m}$ (26.4 lb/ft) buttress thread casing; the smooth casing remained at 1097.06 mbgl (3599.2') and the end of the slotted casing with the shoe remained at $1293.91 \mathrm{mbgl}$ (4245.1').

The casing was equipped with a J collar, a float collar, cementing collar, blank collar, blank shoe, 73 centralizers, 4 canvas metal petal baskets, and 6 hammer-1ock stop rings.

With equipment and personnel from the Byron Jackson Company, cemented the $19.4 \mathrm{~cm}\left(7-5 / 8^{\prime \prime} \emptyset\right)$ casing in two stages.

In the first stage cemented with $5.43 \mathrm{~m}^{3}\left(191.8 \mathrm{ft}^{3}\right)$ [4460 kg (9832.6 1b)] of cement in the form of $1: 1$ grout.

In the second stage cemented with $41.3 \mathrm{~m}^{3}\left(1458.5 \mathrm{ft}^{3}\right)$ [36 $900 \mathrm{~kg}$ (81 $349.7 \mathrm{lb})$ ] of cement. While displacing, lost circulation at the surface for several minutes, reestablished circulation and observed that the cement was contaminated at the surface. 
While the cement was setting, released pressure and removed cementing head.

Inserted 3 steel bars with probe cable inside the we11, reached the top of the cement at $997.21 \mathrm{mbgl}\left(3271.6^{\prime}\right)$.

Installed $30.5 \mathrm{~cm}\left(12^{\prime \prime \emptyset) ~ X ~} 20.6 \mathrm{~cm}\left(8-1 / 2^{\prime \prime \emptyset)}\right.\right.$ centralizers, cut $19.4 \mathrm{~cm}$ $\left(7-5 / 8^{\prime \prime} \emptyset\right)$ casing $0.15 \mathrm{~m}\left(0.49^{\prime}\right)$ above the $29.9 \mathrm{~cm}\left(11-3 / 4^{\prime \prime} \emptyset\right)$ we11-head, installed blowout preventer and surface connections.

\section{HYDRAULIC TEST}

Ran in $16.5 \mathrm{~cm}(6-12 / " \emptyset)$ bit and $11.4 \mathrm{~cm}\left(4-1 / 2^{\prime \prime} \emptyset\right)$ drill string down to $997.21 \mathrm{mbgl}\left(3271.6^{\prime}\right)$, where the top of the cement was reached.

Closed blowout preventer, satisfactorily tested casings, cementing job, and surface connections with a pressure of $70 \mathrm{~kg} / \mathrm{cm}^{2}(1000 \mathrm{psig})$ for $15 \mathrm{~min}$.

Drilled through the cement plug and $J$ collar to $1068.65 \mathrm{mbgl}$ (3506.0'), drilled through float collar to $1076.50 \mathrm{mbgl}$ (3531.8'), where the cementing collar was reached.

Pulled the bit and drill string out to the surface.

LOG FOR CEMENTING THE $19.4 \mathrm{~cm}\left(7-5 / 8^{\prime \prime} \emptyset\right)$ CASING

With equipment and personnel from the Schlumberger Company, obtained cementing $\log$ from 1082.9 to $15.2 \mathrm{mbrt}$ (3552.8' to $49.9^{\prime}$ ), while noting that from 1082.9 to $665.7 \mathrm{mbgl}$ (3552.8' to $2184.0^{\prime}$ ') the adherence values were $77.5 \mathrm{~kg} / \mathrm{cm}^{2}$ (1102.3 psig) and from 665.7 to $273.7 \mathrm{mbgl}$ (2184.0' to $898.0^{\prime}$ ) the adherence values were very low, indicating that at $194.65 \mathrm{~m}$ (638.6') there was strong canalization with values of $9.15 \mathrm{~kg} / \mathrm{cm}^{2}(130.1 \mathrm{psig})$ and from 194.65 to $17.95 \mathrm{mbgl}$ (638.6' to $58.9^{\prime}$ ) adherence values were observed in the form of canalized bridges. There is a cement top with good adherence at a depth of $665.7 \mathrm{mbgl}\left(2184.0^{\prime}\right)$.

\section{HYDRAULIC TEST}

Ran in $16.5 \mathrm{~cm}\left(6-12^{\prime \prime} \emptyset\right)$ bit and drill string until it reached the ceinenting collar, which was drilled through and the cement plug was drilled through down to a depth of $1091.65 \mathrm{mbgl}$ (3581.5').

Closed blowout preventer, made a hydraulic test on various occasions without success; the pressure was increased to $63 \mathrm{~kg} / \mathrm{cm}^{2}$ (900 psig), dropping in 10 min to zero, since it was being held down at the cement outlets. 


\section{COMPLETION}

With the $16.5 \mathrm{~cm}\left(6-1 / 2^{\prime \prime} \emptyset\right)$ bit, continued drilling through the cement to $1096.57 \mathrm{mbgl}\left(3597.6^{\prime}\right)$, reached blank collar, drilled through it and drilled through the cement plug down to $1268.65 \mathrm{mbgl}$ (4162.2'). From this depth to $1293.85 \mathrm{mbg} 1\left(4244.9^{\prime}\right)$, the inside of the slotted casing was found to be open.

Circulated at the bottom, cleaning the well of cement. Immediately pumped a $10 \mathrm{~m}^{3}\left(353.1 \mathrm{ft}^{3}\right)$ air pocket from the water and displaced with $15 \mathrm{~m}^{3}$ (529.7 $\mathrm{ft}^{3}$ ) of mud. Pulled the drill string out, disconnected pipe by pipe at the surface.

\section{THERMAL LOG}

With equipment and personnel from the Federal Electricity Commission, tried to obtain temperature $\log$ down to the bottom, but without success due to breakdown in the Kuster equipment.

Welded blank cover with outlet and $5.1 \mathrm{~cm}\left(2^{\prime \prime} \emptyset\right)$ valve on the $19.4 \mathrm{~cm}$ (7-5/8" $\emptyset$ ) casing. The construction of this well was considered completed at 15:00 h on October 16, 1973.

$$
\begin{aligned}
& \text { Compiled } \\
& \text { (signed) }
\end{aligned}
$$

Raul Rivera 01guin
Reviewed

$$
\text { (signed) }
$$

Engineer Rene de Leon Botello

SUPERINTENDENT OF WELL DRILLING

Approved

$$
\text { (signed) }
$$

Engineer Bernardo Dominguez A. GENERAL SUPERINTENDENT 
SP-GAMMA RAY OVERLAYS WELL 27 


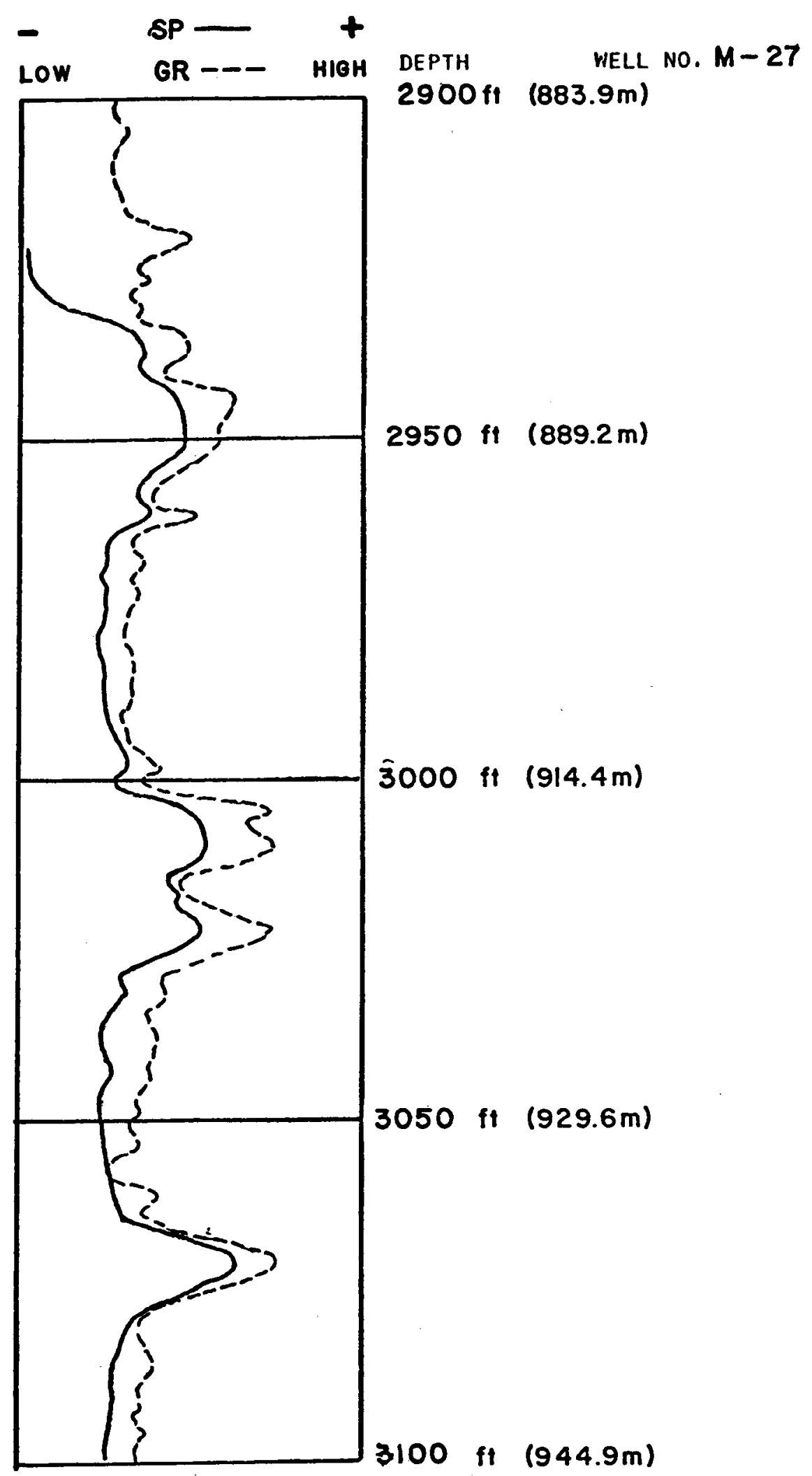

Fig. D-7. SP-Gamma Ray Overlay. 


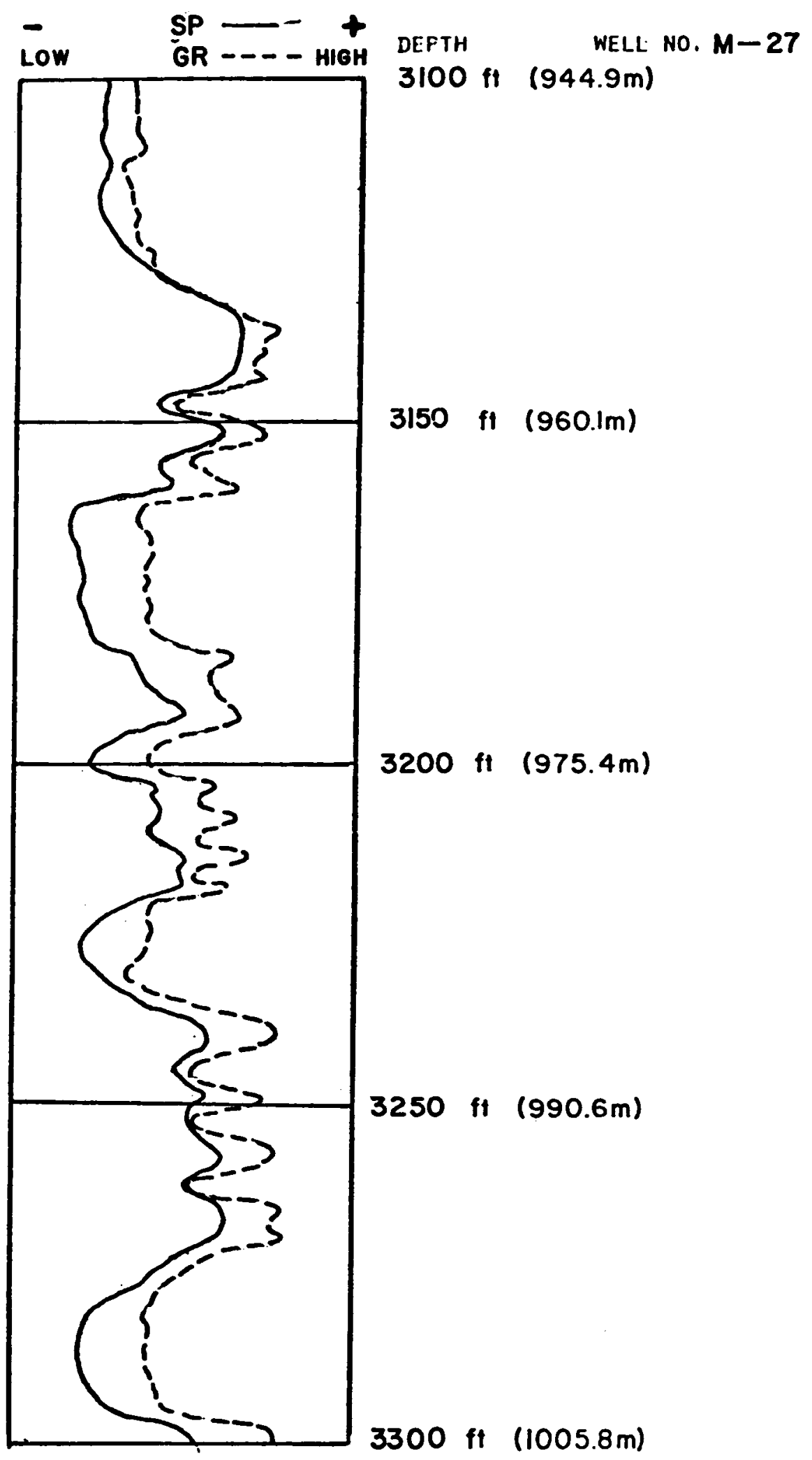

Fig. D-8. SP-Gamma Ray Overlay. 


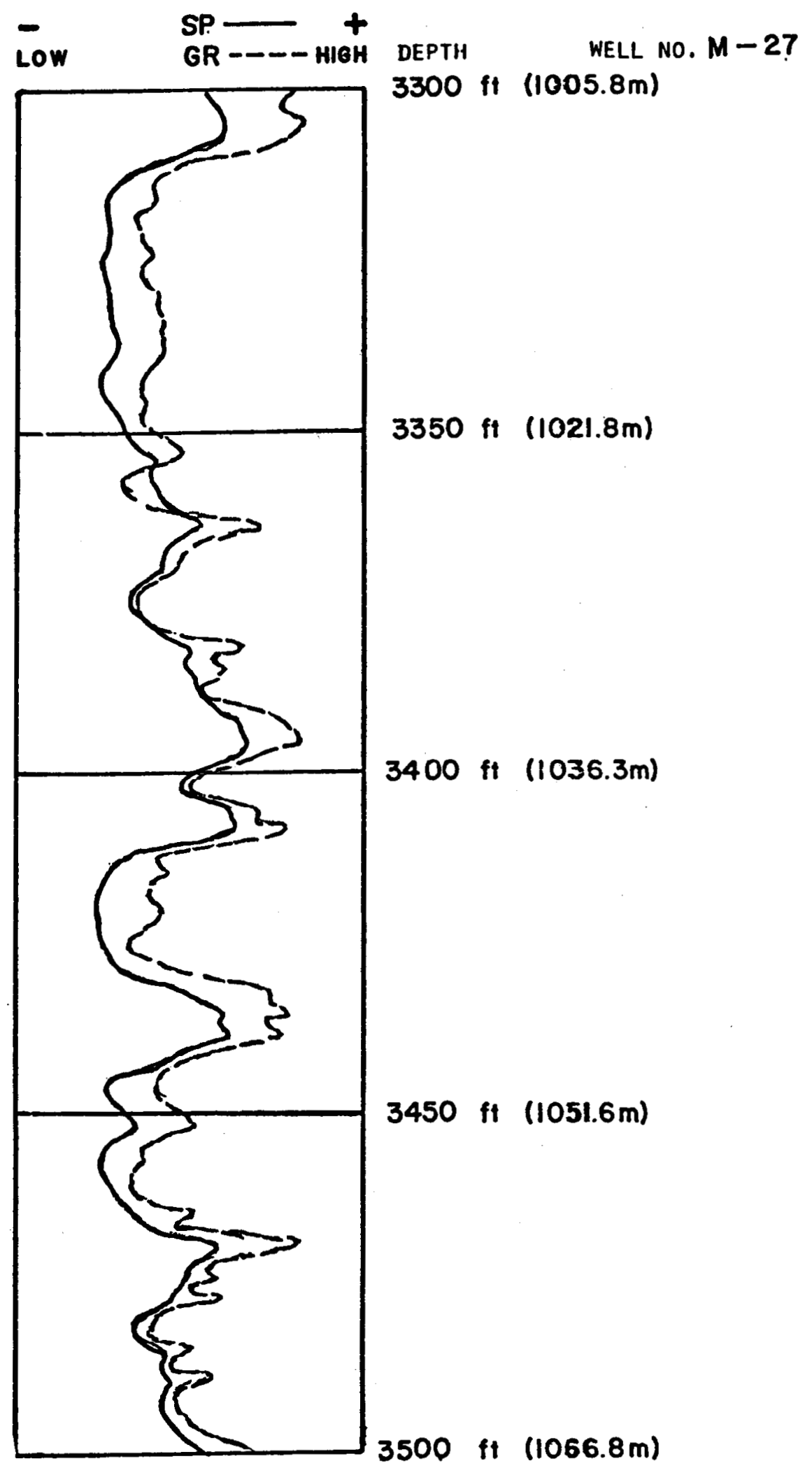

Fig. D-9. SP-Gamma Ray Overlay. 


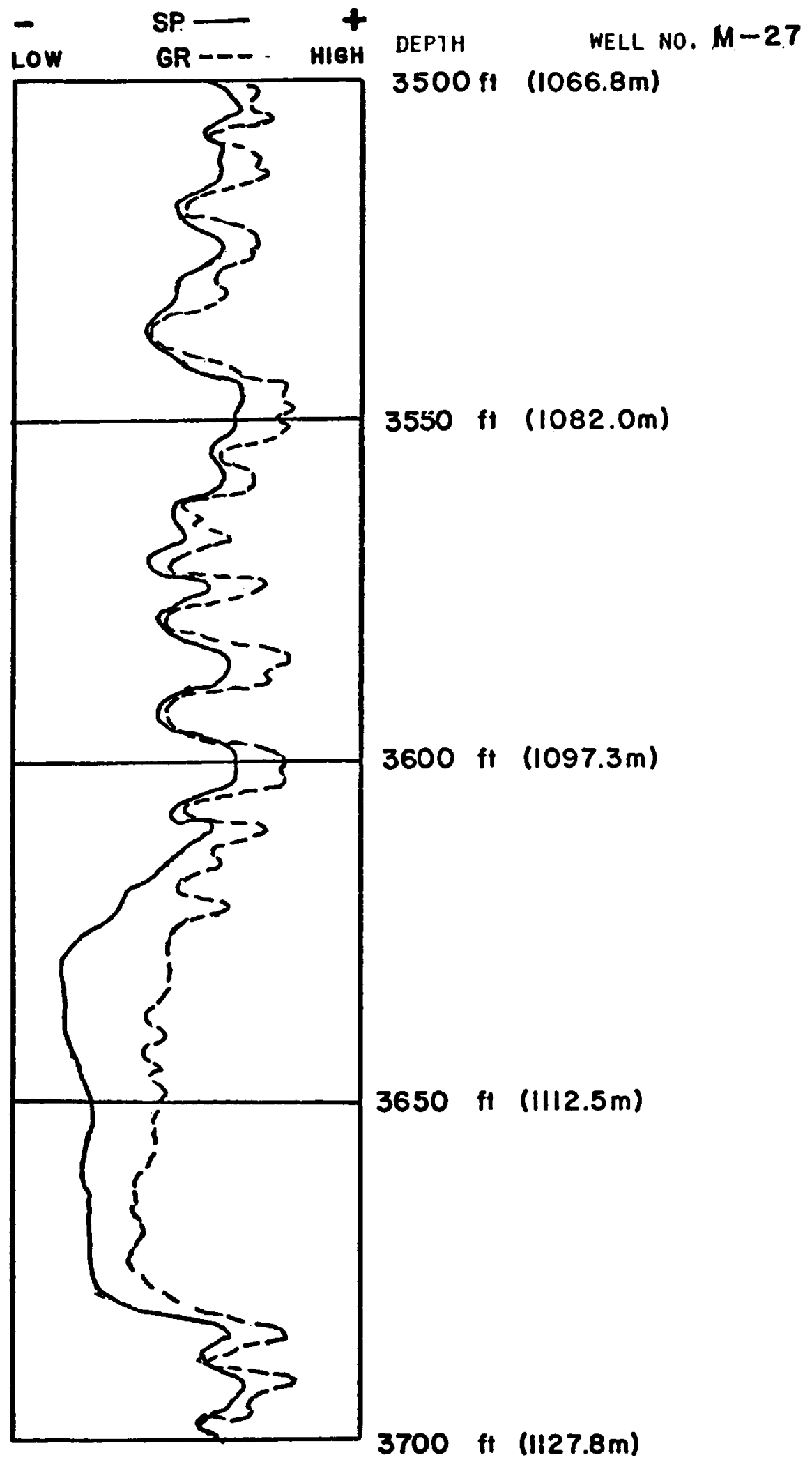

Fig. D-10. SP-Gamma Ray Overlay. 


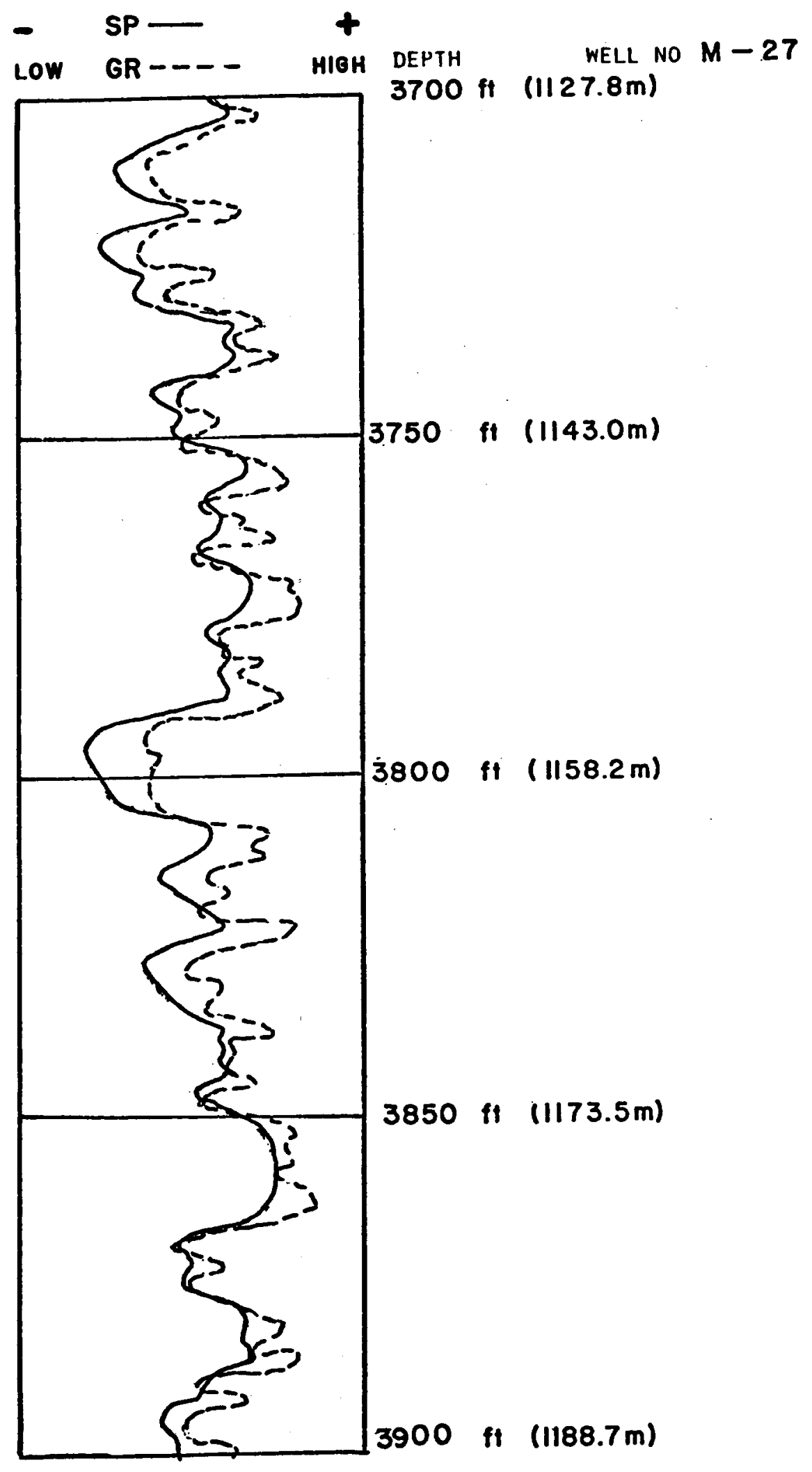

Fig. D-11. SP-Gamma Ray Overlay. 

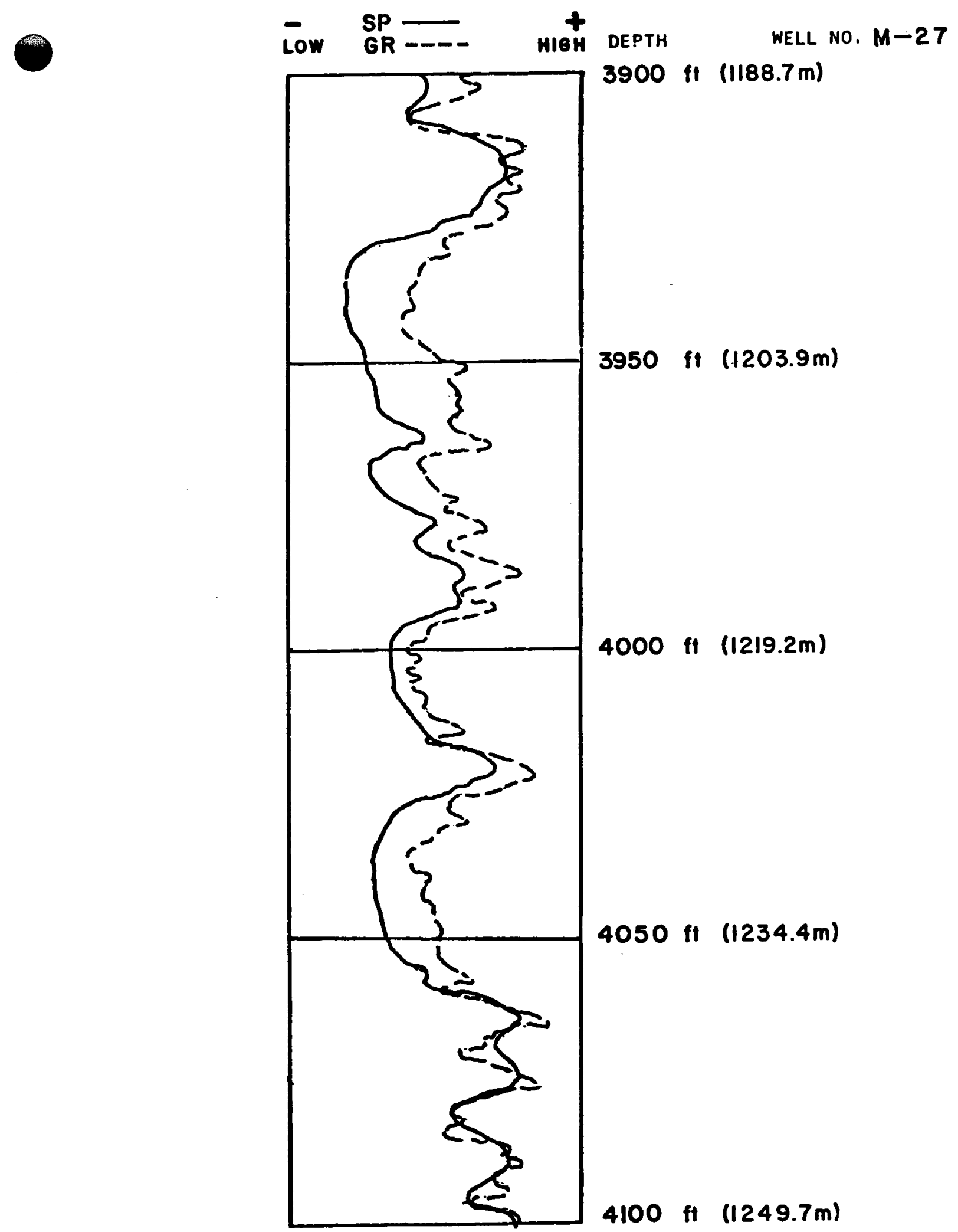

Fig. D-12. SP-Gamna Ray Overlay. 


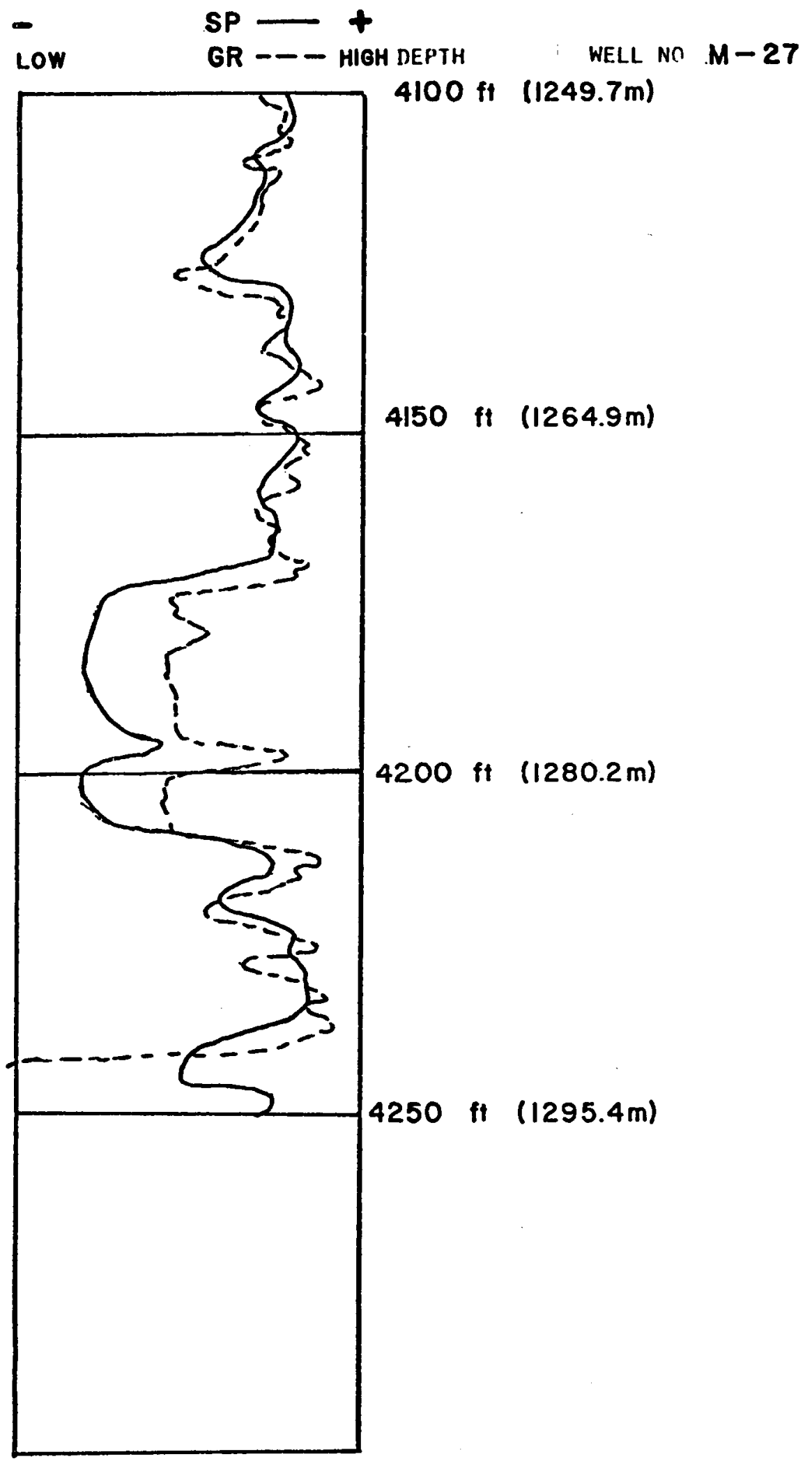

Fig. D-13. SP-Gamma Ray Overlay. 


\section{COMPUTED RESULTS WELL 27}

WELL MUHBER $=27$

FIELD : CERRO PRIETO

RANGE : FRON 3030 TO 3064

COMPUTED DATA IS AS BELOU:

$\begin{array}{lc}\text { Taf }= & 75.000 \\ \text { RHOnf }= & 1.100 \\ \text { PHIDC }= & 0.04 \\ \text { PHINC }= & 0.29 \\ \text { AN }= & 1.00 \\ \text { AM }= & 2.30 \\ \text { RHCLY }= & 0.10 \\ \text { TDEEP }= & 202.0\end{array}$

TDEEP $=202.0$

RSH $=1.50$

DEPTH SP GR PHId PHIn RT USH PHIE PHITD VSHGR RLSP PPMSP RHAX PPWAX RWAD PPWD SW RHF ZFRSAPR Floating divide check $P C=33024$

KFRSAPR Floating overflow $\quad P C=31303$

$\begin{array}{llllllllllllllll}3030 & -55 . & 91 & 0.26 & 0.26 & 1.8 & 0.00 & 0.26 & 0.26 & 0.257 & 0.06 & 42976 . & 0.00 * * * *+* * & 0.08 & 30706 . & 0.86\end{array}$

$3032 \quad-54 . \quad 94.0 .220$

$\begin{array}{lllllllllllllllll}.24 & 2.2 & 0.08 & 0.22 & 0.23 & 1.000 & 0.06 & 42192 . & 0.21 & 10956 . & 0.07 & 34765 . & 0.88 & 0.04 & 1.88\end{array}$

$\begin{array}{lllllllllllllllllllll}3034 & -58 . & 89 . & 0.26 & 0.24 & 1.8 & 0.00 & 0.26 & 0.26 & 0.762 & 0.06 & 44611 . & 0.21 & 10951 . & 0.08 & 29951 . & 0.84 & 0.04 & 2.12\end{array}$

$\begin{array}{lllllllllllllllllllll}3036 & -59 . & 89 . & 0.29 & 0.25 & 1.5 & 0.00 & 0.30 & 0.30 & 0.762 & 0.06 & 45208 . & 0.20 & 11119 . & 0.09 & 26784 . & 0.79 & 0.04 & 2.18\end{array}$

$\begin{array}{llllllllllllllllllllll}3038 & -60 . & 89 . & 0.31 & 0.27 & 1.1 & 0.00 & 0.32 & 0.32 & 0.762 & 0.06 & 45801 . & 0.20 & 11101 . & 0.08 & 30815 . & 0.84 & 0.04 & 2.25\end{array}$

$\begin{array}{lllllllllllllllllllllll}3040 & -61 . & 88 . & 0.31 & 0.28 & 0.9 & 0.00 & 0.31 & 0.31 & 0.714 & 0.06 & 46190 . & 0.14 & 16385 . & 0.06 & 42346 . & 0.96 & 0.06 & 2.20\end{array}$

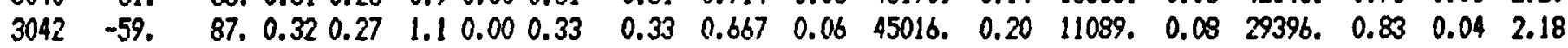

$\begin{array}{lllllllllllllllllllll}3044 & -58 . & 89 & 0.30 & 0.26 & 0.9 & 0.00 & 0.31 & 0.31 & 0.762 & 0.06 & 44424 . & 0.16 & 14312 . & 0.06 & 42344 . & 0.98 & 0.05 & 2.04\end{array}$

$\begin{array}{llllllllllllllllllll}3046 & -60 . & 87 . & 0.32 & 0.27 & 0.8 & 0.00 & 0.33 & 0.33 & 0.667 & 0.06 & 45605 . & 0.16 & 14651 . & 0.06 & 40397 . & 0.95 & 0.05 & 2.17\end{array}$

$\begin{array}{llllllllllllllllllllll}3049 & -61 . & 85 . & 0.33 & 0.26 & 0.7 & 0.00 & 0.34 & 0.34 & 0.571 & 0.06 & 45991 . & 0.15 & 15082 . & 0.06 & 41993 & 0.96 & 0.05 & 2.22\end{array}$

$\begin{array}{lllllllllllllllllllll}3050 & -60 . & 85 . & 0.33 & 0.24 & 0.3 & 0.00 & 0.34 & 0.34 & 0.571 & 0.06 & 45411 . & 0.07 & 36058 . & 0.03 & 101419 . & 1.42 & 0.14 & 1.71\end{array}$

$\begin{array}{llllllllllllllllllllll}3052 & -60 . & 84 . & 0.33 & 0.25 & 0.7 & 0.00 & 0.34 & 0.34 & 0.524 & 0.06 & 45411 . & 0.15 & 15345 . & 0.06 & 44994 . & 1.00 & 0.05 & 2.14\end{array}$

$\begin{array}{llllllllllllllllllll}3054 & -59 . & 85 . & 0.32 & 0.27 & 0.8 & 0.00 & 0.33 & 0.33 & 0.571 & 0.06 & 44827 . & 0.14 & 16728 . & 0.06 & 42916 . & 0.98 & 0.06 & 2.05\end{array}$

3056 -58. $\quad 79.0 .290 .26 \quad 0.7 \quad 0.00 \quad 0.29$

$\begin{array}{llllllll}3058 & -58 . & 76 . & 0.20 & 0.20 & 1.0 & 0.00 & 0.20\end{array}$

$\begin{array}{lllllllllllll}0.29 & 0.286 & 0.06 & 44055 . & 0.13 & 18370 . & 0.04 & 59057 . & 1.14 & 0.06 & 1.95\end{array}$

$\begin{array}{lllllllllllll}0.20 & 0.143 & 0.06 & 44055 . & 0.11 & 21083 . & 0.02 & 12393 \% & 1.57 & 0.07 & 1.39\end{array}$

$\begin{array}{lllllllllllllllllll}3062 & -56 . & 89 . & 0.27 & 0.27 & 0.7 & 0.00 & 0.27 & 0.27 & 0.762 & 0.06 & 42879 . & 0.10 & 22851 . & 0.04 & 74754 . & 1.28 & 0.08 & 1.73\end{array}$

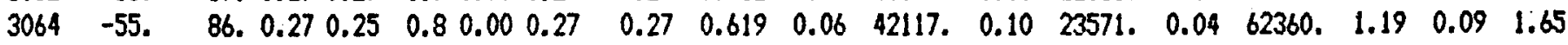


NELL MMMBER $=27$

FIELD : CERRO FRIETO

RANBE : FROM 3030 TO 3064

$\begin{array}{lc}\text { COMPUTED } & \text { DATA IS AS } \\ \text { TARF } & 75.000 \\ \text { RHOnf }= & 1.100 \\ \text { PHIDC }= & 0.04 \\ \text { PHINC }= & 0.29 \\ \text { AN }= & 1.00 \\ \text { AM }=2.30 \\ \text { RHCLY }=0.10 \\ \text { TDEEP }=450.0 \\ \text { RSH }=1.50\end{array}$

\begin{tabular}{|c|c|c|c|c|c|c|c|c|c|c|c|c|c|c|}
\hline $\begin{array}{r}\text { DEPTH } \\
3030\end{array}$ & $\begin{array}{l}\text { SP } \\
-55 .\end{array}$ & $\begin{array}{l}\text { GR PHId PHIn } \\
91.0 .26 \quad 0.26\end{array}$ & $\begin{array}{l}\text { Rt VSH PHIE } \\
1.80 .000 .26\end{array}$ & $\begin{array}{l}\text { PHITD } \\
0.26\end{array}$ & $\begin{array}{c}\text { VSHGR } \\
0.857\end{array}$ & $\begin{array}{l}\text { RiLSP } \\
0.04\end{array}$ & $\begin{array}{c}\text { PPMSP } \\
24985 .\end{array}$ & $\begin{array}{l}\text { RHAX } \\
0.05\end{array}$ & $\begin{array}{l}\text { PPMAX } \\
20110 .\end{array}$ & $\begin{array}{l}\text { RWA } \\
0.08\end{array}$ & $\begin{array}{l}0 \text { PPMD } \\
12800 .\end{array}$ & $\begin{array}{l}\text { SW } \\
0.74\end{array}$ & $\begin{array}{l}\text { Rif } \\
0.04\end{array}$ & 1.20 \\
\hline 303 & 54. & 0.220 .24 & .20 .08 & 0.23 & 1.000 & 0.04 & 24859. & 0.06 & 19163. & 0.07 & 14644. & 0.76 & 0.04 & \\
\hline 034 & 58 & 0.24 & $\begin{array}{lll}1.8 & 0.00 & 0.26\end{array}$ & 0.26 & 0.762 & 0.04 & 25355. & 0.06 & & 0.08 & 12560. & 0.73 & 0. & 30 \\
\hline 13 & & & & 0.30 & 0.762 & 0.04 & 25476. & 06 & & 0.09 & 264. & 69 & & 32 \\
\hline 03 & -60 & 0.2 & & 0.32 & 0.762 & 0.04 & 25595. & 0.06 & 19421. & 0.08 & & 0.73 & 0. & 1.35 \\
\hline 04 & 61. & & & 0.2 & 0.714 & 0.04 & 25713. & 0.04 & & 0.06 & & 84 & & 1.27 \\
\hline 24 & - & & 1.1 & 0.33 & 0.667 & 0.04 & 25476. & 0.06 & 19400. & 0.08 & 12397. & 72 & & 1.32 \\
\hline 3044 & -58. & .26 & 0.9 & 0.31 & 0.762 & 0.04 & 25355. & 0.04 & 25148. & 0.06 & & .85 & 0. & 1.22 \\
\hline $304 c$ & -60 . & 0.27 & 0.8 & 0.33 & 0.667 & 0.04 & 25595. & 0.04 & & 0.06 & & 0.83 & & 1.27 \\
\hline 74! & -61 . & .26 & 0.70. & 0.34 & 0.571 & 0.04 & 25713. & 0.04 & & 0.06 & 17643. & 0.84 & 06 & 1.30 \\
\hline 3050 & -60. & 85. 0.330 .24 & $0.30 .00 \quad 0.34$ & 0.34 & 0.571 & 0.04 & 25595. & 0.02 & 64346. & 0.03 & 41690. & 1.24 & 0.20 & 0.77 \\
\hline 3052 & -60 & 330.25 & 0.7 & 0.34 & 0.524 & 0.04 & 25595. & 0.04 & & 0.06 & 371. & 0.87 & 06 & 1.26 \\
\hline 305 & -59 & $\begin{array}{lll}\text { 85. } & 0.32 & 0.27\end{array}$ & 0.80 & 0.33 & 0.571 & 0.04 & 25476 . & 0.04 & 29470 . & 0.06 & 18021. & 0.86 & 0.06 & 1.20 \\
\hline 3056 & -58. & 79. 0.290 .26 & 0.70. & 0.29 & 0.286 & 0.04 & 25355. & 0.04 & 32415. & 0.04 & 24733. & 0.99 & 0.07 & 1.13 \\
\hline 305 & & 76 & & 0 & 0.143 & 0.04 & & 0.03 & & 0.02 & 73. & 1.36 & 0.09 & 1.01 \\
\hline 2 & & & & 4 & 0.000 & 0.04 & & 0.03 & & 0.04 & & 1.09 & 0.08 & 1.08 \\
\hline 3062 & -56. & 270.27 & & .27 & 0.762 & 0.04 & & 0.03 & & 0.04 & & 1.10 & 0.10 & 0.97 \\
\hline 3064 & -55. & 86. 0.270 .25 & $\begin{array}{llll}0.8 & 0.00 & 0.27\end{array}$ & 0.27 & 0.619 & 0.04 & & 0.03 & 41765. & 0.04 & 26218. & 1.02 & 0.10 & 0.92 \\
\hline
\end{tabular}

\section{TABLE 27-2'}

TDEEP IS USED
$R \operatorname{Rnf}=\quad 0.300$

$$
\begin{array}{lc}
\text { Tal }= & 75.000 \\
\text { RHOnf }= & 1.100 \\
\text { PHIDC }= & 0.04 \\
\text { PHINC }= & 0.29 \\
\text { AN }= & 1.00 \\
\text { AM }=\quad 2.30 \\
\text { RHCLY }=0.10 \\
\text { TOEEP }=450.0 \\
\text { RSH }=1.50
\end{array}
$$


WELL NLMAER $=27$

FIELU : CERRO PRIETO

RANGE : FROM 3030 TO 3064

COMPUTED DATA IS AS BEIOUE

$T_{\text {m } f}=\quad 75.000$

RHOmf $=\quad 1.100$

PHIDC $=\quad 0.04$

PHINC $=\quad 0.28$

$A N=1.00$

AM $=2.00$

RHCLY $=0.10$

TDEEP $=450.0$

$R S H=1.50$

\begin{tabular}{|c|c|c|c|}
\hline DEFTH & $\mathbf{S P}$ & GR PHId PHIn & USH F \\
\hline 3030 & -55. & 91.0 .260 .26 & 1.80 .00 \\
\hline 3032 & -54 . & $94.0 .22 \quad 0.24$ & 2.20 .0 \\
\hline 3034 & -58. & 89. $0.26 \quad 0.24$ & 1.80 .00 \\
\hline 3036 & -59. & 89.0 .290 .25 & 1.50 .00 \\
\hline 3038 & -60 & 89. 0.310 .27 & 1.10 .00 \\
\hline 3040 & -61. & $\begin{array}{lll}88 . & 0.31 & 0.28\end{array}$ & 0.90 .00 \\
\hline 3042 & -59. & 87. $0.32 \quad 0.27$ & 1.10 .00 \\
\hline 3044 & -58. & 89. 0.300 .26 & 0.90 .00 \\
\hline 3046 & -60 & 87. $0.32 \quad 0.27$ & 0.80 .00 \\
\hline 3048 & -61. & 85.0 .330 .26 & 0.70 .00 \\
\hline 3050 & -60 & 85.0 .330 .24 & 0.30 .00 \\
\hline 3052 & -60. & 84. 0.330 .25 & 0.70 .00 \\
\hline 3054 & -59. & 85.0 .320 .27 & 0.80 .00 \\
\hline 3056 & -58. & 79. 0.290 .26 & 0.70 .00 \\
\hline 3058 & -58. & 76. 0.200 .20 & 1.00 .00 \\
\hline 3060 & -57. & 73. 0.240 .23 & 1.00 .00 \\
\hline 3062 & -56. & 89. 0.270 .27 & 0.70 .00 \\
\hline 3064 & $-5 i 5$. & 86. 0.270 .25 & 0.80 .00 \\
\hline
\end{tabular}

TABLE 27-3'

TDEEP IS USED
PHITD VSHGR RWSP PPMSP RWAX PPMAX RHAD PPMD SH RHF

$\begin{array}{llllllllllll}0.26 & 0.857 & 0.04 & 24985 & 0.05 & 20110 . & 0.12 & 8263 & 0.60 & 0.04 & 1.20\end{array}$

$\begin{array}{lllllllllllllllllll}0.23 & 1.000 & 0.04 & 24859 & 0.06 & 19163 . & 0.11 & 8845 . & 0.61 & 0.04 & 1.18\end{array}$

$\begin{array}{lllllllllll}0.26 & 0.762 & 0.04 & 25355 . & 0.06 & 19153 . & 0.12 & 8142 . & 0.60 & 0.04 & 1.30\end{array}$

$\begin{array}{llllllllllll}0.30 & 0.762 & 0.04 & 25476 . & 0.06 & 19452 . & 0.13 & 7597 . & 0.57 & 0.04 & 1.32\end{array}$

$\begin{array}{lllllllllll}0.32 & 0.762 & 0.04 & 25595 & 0.06 & 19421 . & 0.11 & 8880 & 0.62 & 0.04 & 1.35\end{array}$

$\begin{array}{llllllllllll}0.31 & 0.714 & 0.04 & 25713 . & 0.04 & 28857 . & 0.09 & 12105 . & 0.71 & 0.06 & 1.27\end{array}$

$\begin{array}{lllllllllllll}0.33 & 0.667 & 0.04 & 25476 . & 0.06 & 19400 . & 0.12 & 8630 & 0.61 & 0.04 & 1.32\end{array}$

$\begin{array}{llllllllllll}0.31 & 0.762 & 0.04 & 25355 . & 0.04 & 25148 . & 0.09 & 11998 . & 0.71 & 0.05 & 1.22\end{array}$

$\begin{array}{llllllllllll}0.33 & 0.667 & 0.04 & 25595 . & 0.04 & 25753 . & 0.09 & 11724 . & 0.70 & 0.05 & 1.27\end{array}$

$\begin{array}{llllllllllll}0.34 & 0.571 & 0.04 & 25713 & 0.04 & 26524 & 0.08 & 12392 & 0.72 & 0.06 & 1.30\end{array}$

$\begin{array}{llllllllllll}0.34 & 0.571 & 0.04 & 25595 . & 0.02 & 64346 . & 0.04 & 29109 . & 1.06 & 0.20 & 0.77\end{array}$

$\begin{array}{llllllllllll}0.34 & 0.524 & 0.04 & 25595 . & 0.04 & 26994 & 0.08 & 13265 . & 0.74 & 0.06 & 1.26\end{array}$

$\begin{array}{llllllllllll}0.33 & 0.571 & 0.04 & 25476 . & 0.04 & 29470 . & 0.08 & 12492 . & 0.72 & 0.06 & 1.20\end{array}$

$\begin{array}{llllllllllll}0.29 & 0.286 & 0.04 & 25355 . & 0.04 & 32415 . & 0.06 & 16494 & 0.82 & 0.07 & 1.13\end{array}$

$\begin{array}{llllllllllll}0.20 & 0.143 & 0.04 & 25355 & 0.03 & 37289 & 0.04 & 29584 & 1.07 & 0.09 & 1.07\end{array}$

$\begin{array}{lllllllllll}0.24 & 0.000 & 0.04 & 25233 & 0.03 & 34149 & 0.06 & 18913 & 0.89 & 0.08 & 1.08\end{array}$

$\begin{array}{lllllllllll}0.27 & 0.762 & 0.04 & 25110 . & 0.03 & 40470 . & 0.05 & 20106 . & 0.90 & 0.10 & 0.97\end{array}$

$\begin{array}{llllllllllll}0.27 & 0.619 & 0.04 & 24985 & 0.03 & 41765 . & 0.06 & 17040 . & 0.84 & 0.10 & 0.92\end{array}$ 
WELL NMBER $=27$

FIELD : CEFRO PRIETO

RANGE : FROM 3030 TO 3064

$\begin{array}{lc}\text { CONPUTED } & \text { DATA } \\ \text { Tnf }= & 75.000 \\ \text { RHOmf }= & 1.100 \\ \text { FHIDC }= & 0.04 \\ \text { FHINC }= & 0.29 \\ \text { AN }= & 1.00 \\ \text { AM }= & 2.50 \\ \text { RWCLY }= & 0.10 \\ \text { TDEEF }= & 450.0 \\ \text { RSH }=1.50\end{array}$

$\begin{array}{rrllllll}\text { DEPTH } & \text { SP } & \text { GR } & \text { PHId PHIn } & \text { Rt } & \text { USH PHIE } \\ 3030 & -55 . & 91 . & 0.26 & 0.26 & 1.8 & 0.00 & 0.26 \\ 3032 & -54 . & 94 . & 0.22 & 0.24 & 2.2 & 0.08 & 0.22 \\ 3034 & -58 . & 89 . & 0.26 & 0.24 & 1.8 & 0.00 & 0.26 \\ 3036 & -59 . & 89 . & 0.29 & 0.25 & 1.5 & 0.00 & 0.30 \\ 3038 & -60 . & 89 . & 0.31 & 0.27 & 1.1 & 0.00 & 0.32 \\ 3040 & -61 . & 88 . & 0.31 & 0.28 & 0.9 & 0.00 & 0.31 \\ 3042 & -59 . & 87 . & 0.32 & 0.27 & 1.1 & 0.00 & 0.33 \\ 3044 & -56 . & 89 . & 0.30 & 0.26 & 0.9 & 0.00 & 0.31 \\ 3046 & -60 . & 87 . & 0.32 & 0.27 & 0.8 & 0.00 & 0.33 \\ 3048 & -61 . & 85 . & 0.33 & 0.26 & 0.7 & 0.00 & 0.34 \\ 3050 & -60 . & 85 . & 0.33 & 0.24 & 0.3 & 0.00 & 0.34 \\ 3052 & -60 . & 84 . & 0.33 & 0.25 & 0.7 & 0.00 & 0.34 \\ 3054 & -59 . & 85 . & 0.32 & 0.27 & 0.8 & 0.00 & 0.33 \\ 3056 & -58 . & 79 . & 0.29 & 0.26 & 0.7 & 0.00 & 0.29 \\ 3058 & -58 . & 76 . & 0.20 & 0.20 & 1.0 & 0.00 & 0.20 \\ 3060 & -57 . & 73 . & 0.24 & 0.23 & 1.0 & 0.00 & 0.24 \\ 3062 & -56 . & 89 . & 0.27 & 0.27 & 0.7 & 0.00 & 0.27 \\ 3064 & -55 . & 86 . & 0.27 & 0.25 & 0.8 & 0.00 & 0.27\end{array}$
TABLE 27-4'

TDEEP IS USED
FHITD USHGR RWSP FPMSP RWAX PPMAX RWAD PPTD SW RTF $\begin{array}{llllllllllll}0.26 & 0.857 & 0.04 & 24985 & 0.05 & 20110 . & 0.06 & 17194 . & 0.84 & 0.04 & 1.20\end{array}$ $\begin{array}{llllllllllllll}0.23 & 1.000 & 0.04 & 24859 & 0.06 & 19163 . & 0.05 & 20488 . & 0.87 & 0.04 & 1.18\end{array}$ $\begin{array}{llllllllllll}0.26 & 0.762 & 0.04 & 25355 . & 0.06 & 19153 . & 0.06 & 16822 . & 0.83 & 0.04 & 1.30\end{array}$ $\begin{array}{lllllllllllll}0.30 & 0.762 & 0.04 & 25476 . & 0.06 & 19452 . & 0.07 & 14685 . & 0.78 & 0.04 & 1.32\end{array}$ $\begin{array}{llllllllllll}0.32 & 0.762 & 0.04 & 25595 & 0.06 & 19421 . & 0.06 & 16613 & 0.82 & 0.04 & 1.35\end{array}$ $\begin{array}{llllllllllll}0.31 & 0.714 & 0.04 & 25713 . & 0.04 & 28857 . & 0.05 & 22846 . & 0.95 & 0.06 & 1.27\end{array}$ $\begin{array}{lllllllllll}0.33 & 0.667 & 0.04 & 25476 . & 0.06 & 19400 . & 0.07 & 15819 & 0.81 & 0.04 & 1.32\end{array}$ $\begin{array}{lllllllllll}0.31 & 0.762 & 0.04 & 25355, & 0.04 & 25148 . & 0.05 & 22982 . & 0.96 & 0.05 & 1.22\end{array}$ $\begin{array}{llllllllllll}0.33 & 0.667 & 0.04 & 25595 . & 0.04 & 25753 . & 0.05 & 21615 & 0.93 & 0.05 & 1.27\end{array}$ $\begin{array}{lllllllllllll}0.34 & 0.571 & 0.04 & 25713 & 0.04 & 26524 & 0.05 & 22376, & 0.94 & 0.06 & 1.30\end{array}$ $\begin{array}{lllllllllll}0.34 & 0.571 & 0.04 & 25595 . & 0.02 & 64346 & 0.02 & 53081 . & 1.38 & 0.20 & 0.77\end{array}$ $\begin{array}{llllllllllll}0.34 & 0.524 & 0.04 & 25595 . & 0.04 & 26994 . & 0.05 & 23920 . & 0.97 & 0.06 & 1.26\end{array}$ $\begin{array}{lllllllllll}0.33 & 0.571 & 0.04 & 25476 . & 0.04 & 29470 . & 0.05 & 23059 & 0.96 & 0.06 & 1.20\end{array}$ $\begin{array}{llllllllllll}0.29 & 0.286 & 0.04 & 25355 . & 0.04 & 32415 & 0.03 & 32489 & 1.12 & 0.07 & 1.13\end{array}$ $\begin{array}{lllllllllll}0.20 & 0.143 & 0.04 & 25355 . & 0.03 & 37289 & 0.02 & 73605 . & 1.60 & 0.09 & 1.07\end{array}$ $\begin{array}{lllllllllll}0.24 & 0.000 & 0.04 & 25233 & 0.03 & 34149 . & 0.03 & 41791 . & 1.25 & 0.08 & 1.08\end{array}$ $\begin{array}{lllllllllll}0.27 & 0.762 & 0.04 & 25110 . & 0.03 & 40470 . & 0.03 & 41782 . & 1.25 & 0.10 & 0.97\end{array}$ $\begin{array}{lllllllllll}0.27 & 0.619 & 0.04 & 24985 & 0.03 & 41765 . & 0.03 & 35051 . & 1.16 & 0.10 & 0.92\end{array}$ 
WELL NMABER $=27$

FIELD : CERRO PRIETO

RANGE : FROM 3030 TO 3064

CONFUTED DATA IS AS BELON:

Tinf $=75.000$

FiHOnf $=1.100$

$\mathrm{PHIDC}=\quad 0.04$

FHINC $=0.29$

$A N=\quad 1.00$

AM $=2.30$

RHCLY $=0.10$

TREEP $=450.0$

$\mathrm{RSH}=1.50$

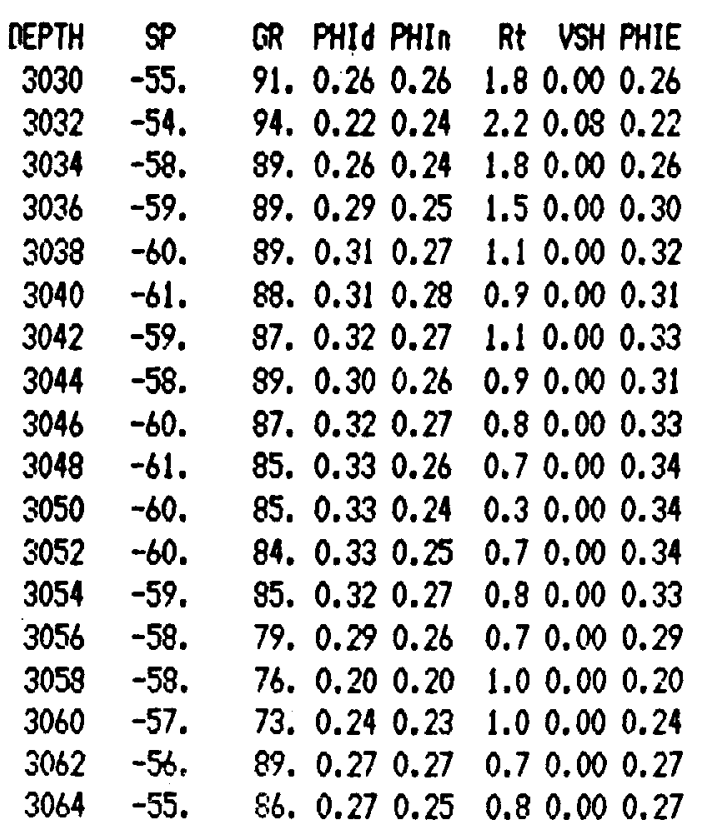

TABLE 27-5'

TDEEP IS USED

$$
R_{m f}=0.500
$$

PHITD USHGR RWSP PPMSP RWAX PPMAX RWAD PPMD SW RMF

$\begin{array}{lllllllllll}0.26 & 0.857 & 0.05 & 21178 . & 0.09 & 11488 . & 0.08 & 12800 . & 0.80 & 0.04 & 1.20\end{array}$ $\begin{array}{lllllllllll}0.23 & 1.000 & 0.05 & 21017, & 0.09 & 10956 . & 0.07 & 14644 . & 0.81 & 0.04 & 1.18\end{array}$ $\begin{array}{lllllllllll}0.26 & 0.762 & 0.05 & 21652 . & 0.09 & 10951 . & 0.08 & 12560 . & 0.78 & 0.04 & 1.30\end{array}$ $\begin{array}{lllllllllll}0.30 & 0.762 & 0.05 & 21808 . & 0.09 & 11119 & 0.09 & 11264 . & 0.74 & 0.04 & 1.32\end{array}$ $\begin{array}{lllllllllll}0.32 & 0.762 & 0.05 & 21963 . & 0.09 & 11101 . & 0.08 & 12912 . & 0.79 & 0.04 & 1.35\end{array}$ $\begin{array}{llllllllllll}0.31 & 0.714 & 0.05 & 22116 . & 0.06 & 16385 & 0.06 & 17694 & 0.90 & 0.06 & 1.27\end{array}$ $\begin{array}{lllllllllll}0.33 & 0.667 & 0.05 & 21808 . & 0.09 & 11089 & 0.08 & 12397 . & 0.77 & 0.04 & 1.32\end{array}$ $\begin{array}{lllllllllllll}0.31 & 0.762 & 0.05 & 21652 . & 0.07 & 14312 . & 0.06 & 17694 . & 0.91 & 0.05 & 1.22\end{array}$ $\begin{array}{lllllllllll}0.33 & 0.667 & 0.05 & 21963 . & 0.07 & 14651 . & 0.06 & 16900 . & 0.89 & 0.05 & 1.27\end{array}$ $\begin{array}{llllllllllll}0.34 & 0.571 & 0.05 & 22116 . & 0.07 & 15082 . & 0.06 & 17643 . & 0.90 & 0.06 & 1.30\end{array}$ $\begin{array}{lllllllllll}0.34 & 0.571 & 0.05 & 21963 . & 0.03 & 36058 . & 0.03 & 41690 . & 1.33 & 0.20 & 0.77\end{array}$ $\begin{array}{lllllllllll}0.34 & 0.524 & 0.05 & 21963 . & 0.07 & 15345 . & 0.06 & 18871 . & 0.93 & 0.06 & 1.26\end{array}$ $\begin{array}{lllllllllll}0.33 & 0.571 & 0.05 & 21808 . & 0.06 & 16728 . & 0.06 & 18021 . & 0.92 & 0.06 & 1.20\end{array}$ $\begin{array}{lllllllllll}0.29 & 0.236 & 0.05 & 21652 . & 0.06 & 18370 . & 0.04 & 24733 . & 1.06 & 0.07 & 1.13\end{array}$ $\begin{array}{lllllllllll}0.20 & 0.143 & 0.05 & 21652 . & 0.05 & 21083, & 0.02 & 50973 . & 1.46 & 0.09 & 1.07\end{array}$ $\begin{array}{lllllllllll}0.24 & 0.000 & 0.05 & 21495 . & 0.06 & 19336 . & 0.04 & 30367 . & 1.17 & 0.08 & 1.08\end{array}$ $\begin{array}{lllllllllll}0.27 & 0.762 & 0.05 & 21337, & 0.05 & 22851 . & 0.04 & 31125 . & 1.18 & 0.10 & 0.97\end{array}$ $\begin{array}{lllllllllll}0.27 & 0.619 & 0.05 & 21178 . & 0.05 & 23571 . & 0.04 & 26218 . & 1.10 & 0.10 & 0.92\end{array}$ 
WELL MUMBER $=27$

FIELD : CERRO PRIETO

RANGE : FROM 3030 TO 3064

CONPUTED DATA IS AS BELON: Rnf $=0.500$ TDEEP IS USED
Tnf $=75.000$

RHOmf $=1.100$

PHIDC $=\quad 0.04$

PHINC $=\quad 0.29$

$A N=\quad 1.00$

AM $=2.50$

RICLY $=0.10$

TDEEP $=450.0$

RSH $=1.50$

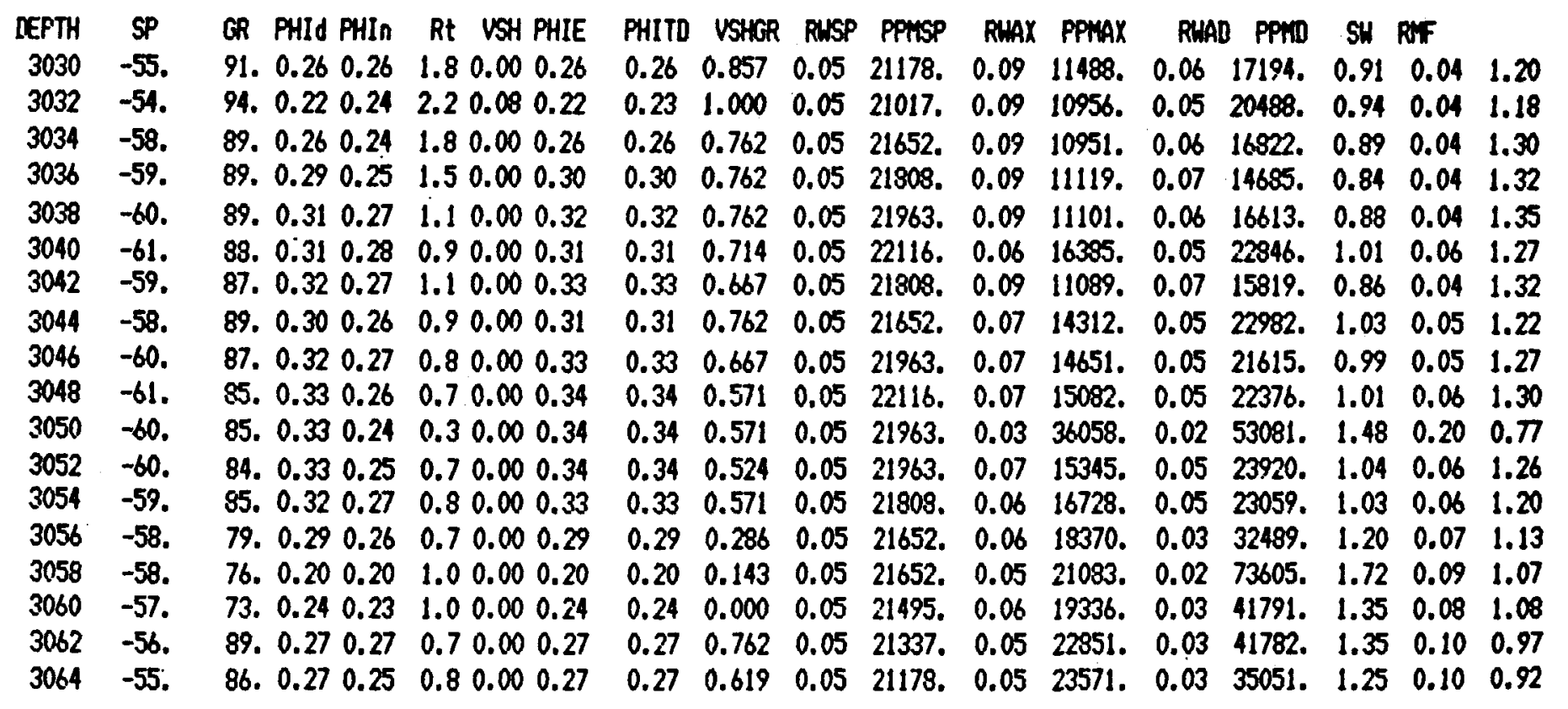

TABLE 27-6! 


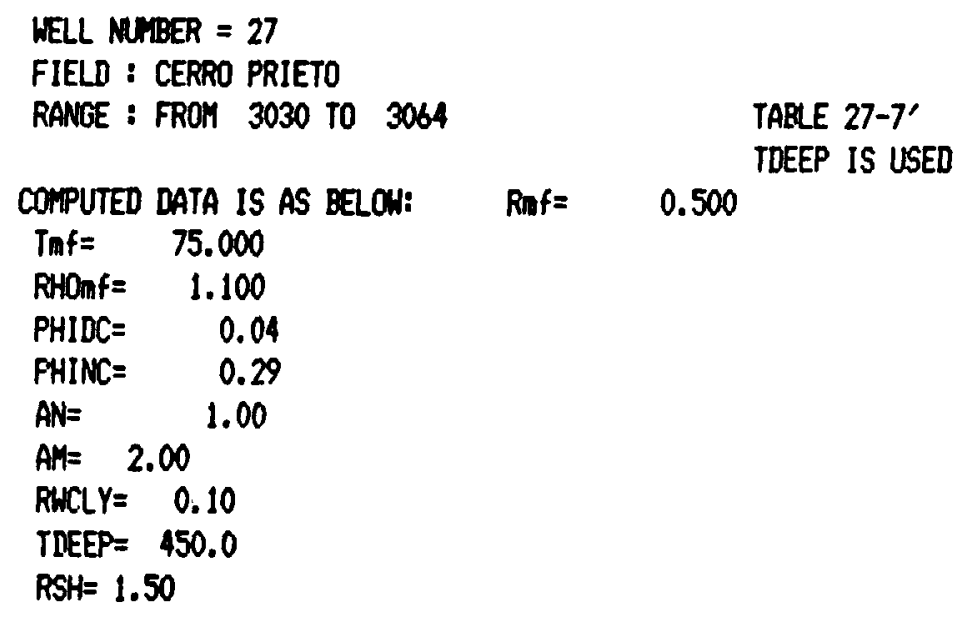

\begin{tabular}{|c|c|c|c|c|c|c|c|c|c|c|c|c|c|c|}
\hline СEPTH & $\mathbf{S P}$ & PHId PHIn & Rt USH PHIE & PHITD & VSHCR & RUSP & PPISP & RWAX & PPMAX & RUAD & PPND & SH & Rif & \\
\hline 3030 & -55. & 260.26 & 1.80 .000 .26 & 0.26 & 0.857 & 0.05 & 21178. & 0.09 & 11488. & 0.12 & 8263. & 0.65 & 0.04 & 1.20 \\
\hline 3032 & -54. & 94 & 2.20 .080 .22 & 0.23 & 1.000 & 0.05 & 21017. & 0.09 & 10956. & 0.11 & 8845. & 0.65 & 0.04 & 1.18 \\
\hline 30.34 & -58. & 60.24 & $\begin{array}{lll}1.8 & 0.00 & 0.26\end{array}$ & 0.26 & 0.762 & 0.05 & 21652 . & 0.09 & 10951. & 0.12 & 8142. & 0.64 & 0.04 & 1.30 \\
\hline 3036 & -59. & 290 & 1.50 .000$. & 0.30 & 0.762 & 0.05 & 21808. & 0.09 & 11119. & 0.13 & 7597. & 0.62 & 0.04 & 1.32 \\
\hline 3038 & -60. & 0.27 & & 0.32 & 0.762 & 0.05 & 21963. & 0.09 & 11101. & 0.11 & 8880. & 0.66 & 04 & 1.35 \\
\hline 3040 & -61. & 88. 0.310 .28 & 0.90 .000$. & 0.31 & 0.714 & 0.05 & 22116 . & 0.06 & 16385. & 0.09 & 12105. & 0.76 & 0.06 & 1.27 \\
\hline 3042 & $-5 \%$ & 0.27 & & 0.33 & 0.667 & 0.05 & 21808. & 0.09 & 11089. & 0.12 & 8630. & 0.65 & & 1.32 \\
\hline 3044 & -58. & 89. 0. & & 0.31 & 0.762 & 0.05 & 21652. & 0.07 & 14312. & 0.09 & 11998. & 0.76 & 05 & 1.22 \\
\hline 3046 & -60. & 87. 0 & 0.8 & 0.33 & 0.667 & 0.05 & 21963. & 0.07 & 14651. & 0.09 & 11724. & 0.75 & 0.05 & 1.27 \\
\hline 3048 & -61. & & 0.7 & 0.34 & 0.571 & 0.05 & 22116. & 0.07 & 15082. & 0.08 & 12392. & 0.77 & 0. & 1.30 \\
\hline 3050 & -60. & & & 0.34 & 0.571 & 0.05 & 21963. & 0.03 & 36058. & 0.04 & 29109. & 1.13 & 0.20 & 0.77 \\
\hline 3052 & -60. & 0.25 & 0.7 & 0.34 & 0.524 & 0.05 & 21963. & 0.07 & 15345. & 0.08 & 13265. & 0.80 & 0.06 & 1.26 \\
\hline 3054 & & & & 0.33 & 0.571 & 0.05 & 21808. & 0.06 & 16728. & 0.08 & 12492. & 0.78 & 0.06 & 1.20 \\
\hline 205 & & 79. 0.1 & 0.70 .000$. & 0.29 & 0.286 & 0.05 & 216 & 0.06 & & 0.06 & 16494. & 0.88 & 0.07 & 1.13 \\
\hline 3058 & -58. & 76. $0.20 \quad 0.20$ & 1.00 .000 .20 & 0.20 & 0.143 & 0.05 & 21652. & 0.05 & 21083. & 0.04 & 29584. & 1.15 & 0.09 & 1.07 \\
\hline 306 & -57 & 73. 0.240 .23 & 1.00 .000$. & 0.24 & 0.000 & 0.05 & 21495. & 0.06 & 1933 & 0.06 & 18913. & 0.94 & 0.08 & 1.08 \\
\hline 306 & -56 & 89. 0.270 .27 & $0.70 .00 \quad 0.27$ & 0.27 & 0.762 & 0.05 & 21337. & 0.05 & 228 & 0.05 & 20106. & 0.97 & 0.10 & 0.97 \\
\hline 3064 & -55. & 86. 0.270 .25 & $0.80 .00 \quad 0.27$ & 0.27 & 0.619 & 0.05 & 21178. & 0.05 & 23571. & 0.06 & 17040. & 0.91 & 0.10 & 0.92 \\
\hline
\end{tabular}


WELL MUMBER $=27$

FIELD : CERKO PRIETO

RANGE : FROM 3630 TO 3680

COMPUTED DATA IS AS BELOW:

$\operatorname{Rim} f=$ 0.500

$\begin{array}{lc}\text { Timf }= & 75.000 \\ \text { RHOnf }= & 1.100 \\ \text { PHIOC= } & 0.04 \\ \text { PHINC }= & 0.29 \\ \text { AN }= & 1.00 \\ \text { AM }=2.30 \\ \text { RHCLY }=0.10 \\ \text { TDEEP }=274.0 \\ \text { RSH }=1.50\end{array}$

\section{$\mathrm{RSH}=1.50$}

$\begin{array}{rc}\text { DEPTH } & \text { SP } \\ 3630 & -72 . \\ 3632 & -72 . \\ 3634 & -72 . \\ 3636 & -72 . \\ 3638 & -72 . \\ 3640 & -72 . \\ 3642 & -70 . \\ 3644 & -69 . \\ 3646 & -68 . \\ 3648 & -66 . \\ 3650 & -64 . \\ 3652 & -64 . \\ 3654 & -63 . \\ 3656 & -64 . \\ 3658 & -65 . \\ 3660 & -65 . \\ 3662 & -65 . \\ 3664 & -65 . \\ 3666 & -64 . \\ 3668 & -64 . \\ 3670 & -65 . \\ 3672 & -64 . \\ 3674 & -64 . \\ 3676 & -64 . \\ 3678 & -63 . \\ 3680 & -60 .\end{array}$

GR PHId PHIn Rt VSH PHIE $\begin{array}{lllllllllllll}93 . & 0.27 & 0.13 & 10.3 & 0.00 & 0.29\end{array}$ $\begin{array}{llllll}94 . & 0.26 & 0.17 & 6.8 & 0.00 & 0.27\end{array}$ 94. $0.26 \quad 0.16 \quad 6.6 \quad 0.00 \quad 0.28$ 91. $0.290 .14 \quad 5.4 \quad 0.00 \quad 0.31$ $\begin{array}{cccccc}90 . & 0.30 & 0.14 & 5.2 & 0.00 & 0.33\end{array}$ 91. $0.310 .15 \quad 45.2 \quad 0.00 \quad 0.34$ 90. $0.330 .13 \quad 5.10 .00 \quad 0.36$ $\begin{array}{llllllllll}87 . & 0.32 & 0.13 & 5.1 & 0.00 & 0.35\end{array}$ 91. $0.290 .18 \quad 3.5 \quad 0.00 \quad 0.31$ $\begin{array}{llllll}89 . & 0.30 & 0.20 & 1.6 & 0.00 & 0.32\end{array}$ 91. $0.300 .200 .30 .00 \quad 0.32$ 91. $0.30 \quad 0.19 \quad 0.8 \quad 0.00 \quad 0.32$ 91. $0.290 .18 \quad 1.1 \quad 0.000 .31$ 93. $0.290 .20 \quad 1.20 .00 \quad 0.30$ $\begin{array}{llllll}91 . & 0.28 & 0.20 & 1.3 & 0.00 & 0.29\end{array}$ 89. $0.280 .19 \quad 0.9 \quad 0.00 \quad 0.29$ $\begin{array}{llllll}85 . & 0.29 & 0.19 & 0.8 & 0.00 & 0.31\end{array}$ 87. $0.30 \quad 0.19 \quad 0.3 \quad 0.00 \quad 0.32$ $\begin{array}{lllllll}83 . & 0.29 & 0.19 & 1.0 & 0.00 & 0.31\end{array}$ $\begin{array}{lllllll}87 . & 0.28 & 0.19 & 1.1 & 0.00 & 0.29\end{array}$ 89. $0.26 \quad 0.19 \quad 1.1 \quad 0.00 \quad 0.27$ 36. $0.290 .19 \quad 0.3 \quad 0.00 \quad 0.31$ 86. $0.290 .20 \quad 0.8 \quad 0.00 \quad 0.30$ 87. $0.290 .21 \quad 0.7 \quad 0.00 \quad 0.30$ 89. $0.28 \quad 0.20 \quad 0.90 .00 \quad 0.29$ 98. $0.25 \quad 0.20 \quad 1.3 \quad 0.00 \quad 0.26$
PHITD VSHGR RHSP PPMSP RWAX PPMAX RWAD PPMD SW RMF $\begin{array}{lllllllllll}0.29 & 0.667 & 0.05 & 39056 & 0.42 & 3699 . & 0.61 & 2537, & 0.28 & 0.01 & 2.76\end{array}$ $\begin{array}{lllllllllll}0.27 & 0.733 & 0.05 & 33915 . & 0.26 & 6098 . & 0.34 & 4572 . & 0.37 & 0.02 & 2.70\end{array}$ $\begin{array}{lllllllllll}0.28 & 0.733 & 0.05 & 38915 & 0.29 & 5443 . & 0.34 & 4647 . & 0.38 & 0.02 & 2.71\end{array}$ $\begin{array}{llllllllllll}0.31 & 0.533 & 0.05 & 38915 . & 0.26 & 6241 . & 0.37 & 4192 . & 0.36 & 0.02 & 2.69\end{array}$ $\begin{array}{lllllllllll}0.33 & 0.467 & 0.05 & 33915, & 0.03 & 58654 . & 0.39 & 4001 . & 0.35 & 0.26 & 1.59\end{array}$ $\begin{array}{lllllllllll}0.34 & 0.533 & 0.05 & 38776 . & 1.89 & 797 . & 3.67 & 416 . & 0.11 & 0.00 & 2.82\end{array}$ $\begin{array}{lllllllllll}0.36 & 0.467 & 0.05 & 38126 . & 0.15 & 11060 . & 0.49 & 3133 . & 0.32 & 0.04 & 2.45\end{array}$ $\begin{array}{lllllllllll}0.35 & 0.267 & 0.05 & 37796 . & 0.15 & 11041 . & 0.46 & 3385 . & 0.33 & 0.04 & 2.38\end{array}$ $\begin{array}{lllllllllll}0.31 & 0.533 & 0.05 & 37462 . & 0.15 & 11360 . & 0.24 & 6842 . & 0.46 & 0.04 & 2.31\end{array}$ $\begin{array}{lllllllllll}0.32 & 0.333 & 0.05 & 36660 . & 0.15 & 11419 & 0.11 & 14954 . & 0.67 & 0.04 & 2.19\end{array}$ $\begin{array}{lllllllllll}0.32 & 0.533 & 0.05 & 35975 . & 0.12 & 13636 . & 0.06 & 32459 & 0.96 & 0.05 & 2.03\end{array}$ $\begin{array}{lllllllllll}0.32 & 0.533 & 0.05 & 35975 . & 0.10 & 16997 . & 0.06 & 32962 . & 0.96 & 0.06 & 1.95\end{array}$ $\begin{array}{lllllllllll}0.31 & 0.533 & 0.05 & 35629 & 0.14 & 12005 . & 0.07 & 24377 . & 0.84 & 0.04 & 2.01\end{array}$ $\begin{array}{lllllllllll}0.30 & 0.667 & 0.05 & 35854 & 0.14 & 11488 . & 0.07 & 23737 & 0.83 & 0.04 & 2.07\end{array}$ $\begin{array}{lllllllllll}0.29 & 0.533 & 0.05 & 36195 . & 0.12 & 13780 . & 0.07 & 238 \% 6 & 0.83 & 0.05 & 2.07\end{array}$ $\begin{array}{lllllllllll}0.29 & 0.400 & 0.05 & 36195 . & 0.10 & 16941 . & 0.06 & 32388 . & 0.95 & 0.06 & 2.01\end{array}$ $\begin{array}{lllllllllll}0.31 & 0.133 & 0.05 & 36195 . & 0.12 & 14651 . & 0.05 & 34239 & 0.98 & 0.05 & 2.06\end{array}$ $\begin{array}{lllllllllll}0.32 & 0.267 & 0.05 & 36195 & 0.12 & 14651 . & 0.06 & 31106 . & 0.93 & 0.05 & 2.06\end{array}$ $\begin{array}{lllllllllll}0.31 & 0.000 & 0.05 & 35733 . & 0.12 & 13731, & 0.06 & 28863 . & 0.91 & 0.05 & 2.01\end{array}$ $\begin{array}{lllllllllll}0.29 & 0.267 & 0.05 & 35733 . & 0.13 & 12774 & 0.07 & 27062 . & 0.88 & 0.04 & 2.03\end{array}$ $\begin{array}{lllllllllll}0.27 & 0.400 & 0.05 & 36072 . & 0.13 & 12774 & 0.05 & 33425 . & 0.97 & 0.04 & 2.09\end{array}$ $\begin{array}{lllllllllll}0.31 & 0.200 & 0.05 & 35733 . & 0.10 & 17572, & 0.06 & 33096 . & 0.97 & 0.06 & 1.93\end{array}$ $\begin{array}{llllllllllll}0.30 & 0.200 & 0.05 & 35613 . & 0.09 & 18520 . & 0.05 & 36091 . & 1.01 & 0.06 & 1.91\end{array}$ $\begin{array}{lllllllllll}0.30 & 0.267 & 0.05 & 35613 . & 0.09 & 20288 . & 0.05 & 39730 . & 1.04 & 0.07 & 1.87\end{array}$ $\begin{array}{lllllllllll}0.29 & 0.400 & 0.05 & 35272 & 0.11 & 16126, & 0.05 & 35433 . & 1.00 & 0.06 & 1.90\end{array}$ $\begin{array}{lllllllllll}0.26 & 1.000 & 0.05 & 34234 . & 0.09 & 18389 & 0.06 & 31398 . & 0.96 & 0.07 & 1.70\end{array}$ 
HELL MUMBER $=27$

FIELD : CERRO PRIETO

RANGE : FROM. 3630 TO 3680

COMPUTED DATA IS AS BELON:

Thf $=\quad 75.000$

FHOnf $=1.100$

PHIDC $=0.04$

PHINC $=0.29$

AN $=\quad 1.00$

$A M=2.30$

RHCLY $=0.10$

TDEEP $=450.0$

$\mathrm{RSH}=1.50$

\begin{tabular}{|c|c|c|c|}
\hline DEPTH & $S P$ & GR PHId PHIn & Rt USH PHIE \\
\hline 3630 & -72. & 93. 0.270 .13 & 10.30 .000 .29 \\
\hline 3632 & -72. & 94. $0.26 \quad 0.17$ & 6.80 .000 .27 \\
\hline 3634 & -72 & 94. 0.260 .16 & $6.60 .00 \quad 0.28$ \\
\hline 3636 & -72 & 91. 0.290 .14 & 5.40 .000 .31 \\
\hline 3638 & -72 & 90. 0.300 .14 & 5.20 .00 \\
\hline 3640 & -72 & 91.0 .310 .15 & 45.20 .0 \\
\hline 3642 & -70 & 90.0 .330 .13 & 5.10 .00 \\
\hline 3644 & -69. & 87. 0.320 .13 & 5.10 .00 \\
\hline 3646 & -68 & 91.0 .290 .18 & 3.50 .00 \\
\hline 3648 & -66 & $\begin{array}{lll}88 . & 0.30 & 0.20\end{array}$ & 1.60 .00 \\
\hline 3650 & -64 & 91.0 .300 .20 & $0.80 .00 \quad 0.32$ \\
\hline 3652 & -64 & 91. 0.300 .19 & $0.8 \quad 0.00 \quad 0.32$ \\
\hline 3654 & -63 & 91.0 .290 .18 & $\begin{array}{llll}1.1 & 0.00 & 0.31\end{array}$ \\
\hline 3656 & -64. & 93. 0.290 .20 & 1.20 .000 .30 \\
\hline 3658 & -65. & 91. 0.280 .20 & $1.30 .00 \quad 0.29$ \\
\hline 3660 & -65. & 39. 0.280 .19 & $0.90 .00 \quad 0.29$ \\
\hline 3662 & -65. & 85. 0.290 .19 & 0.80 .000 .31 \\
\hline 3664 & -65 & 87. 0.300 .19 & $0.8 \quad 0.00 \quad 0.32$ \\
\hline 3666 & -64. & 83. 0.290 .19 & $\begin{array}{lll}1.0 & 0.00 & 0.31\end{array}$ \\
\hline 3668 & -64 & 87. 0.280 .19 & 1.10 .000 .29 \\
\hline 3670 & -65 & 89. 0.260 .19 & $1.10 .00 \quad 0.27$ \\
\hline 3672 & -64 & 86. 0.290 .19 & 0.80 .000 \\
\hline 3674 & -64 & 86.0 .290 .20 & 0.80 .00 \\
\hline 3676 & -64. & 87. 0.290 .21 & 0.70 .00 \\
\hline $\begin{array}{l}3678 \\
3680\end{array}$ & $\begin{array}{l}-63 . \\
-60 .\end{array}$ & $\begin{array}{lll}89 . & 0.28 & 0.20 \\
98 . & 0.25 & 0.20\end{array}$ & \\
\hline
\end{tabular}

TABLE 27-9,

TDEEP 15 USED

\begin{abstract}
PHITD USHGR RUSP PPMSP RWAX PPMAX RWAD PPMD SH RMF $\begin{array}{lllllllllll}0.29 & 0.667 & 0.05 & 23720 . & 0.26 & 3699 . & 0.61 & 1535 . & 0.28 & 0.01 & 1.94\end{array}$ $\begin{array}{lllllllllll}0.27 & 0.733 & 0.05 & 23720 . & 0.16 & 6098 . & 0.34 & 2748 . & 0.37 & 0.02 & 1.89\end{array}$ $\begin{array}{lllllllllll}0.28 & 0.733 & 0.05 & 23720 . & 0.18 & 5443 . & 0.34 & 2792 . & 0.37 & 0.02 & 1.90\end{array}$ $\begin{array}{lllllllllll}0.31 & 0.533 & 0.05 & 23720 . & 0.16 & 6241 . & 0.37 & 2523 . & 0.35 & 0.02 & 1.88\end{array}$ $\begin{array}{llllllllllll}0.33 & 0.467 & 0.05 & 23720 . & 0.02 & 58654 . & 0.39 & 2410 . & 0.34 & 99.00 & 99.00\end{array}$ $\begin{array}{lllllllllll}0.34 & 0.533 & 0.05 & 23720 & 1.17 & 797 . & 3.67 & 262 . & 0.11 & 0.00 & 2.01\end{array}$ $\begin{array}{lllllllllll}0.36 & 0.467 & 0.05 & 23440 . & 0.09 & 11060 . & 0.49 & 1902 . & 0.31 & 0.04 & 1.70\end{array}$ $\begin{array}{lllllllllll}0.35 & 0.267 & 0.05 & 23298 . & 0.09 & 11041 . & 0.46 & 2053 . & 0.32 & 0.04 & 1.66\end{array}$ $\begin{array}{lllllllllll}0.31 & 0.533 & 0.05 & 23155 . & 0.09 & 11360 . & 0.24 & 4100 . & 0.45 & 0.04 & 1.62\end{array}$ $\begin{array}{lllllllllll}0.32 & 0.333 & 0.05 & 22864 . & 0.09 & 11419 & 0.11 & 8983 . & 0.65 & 0.04 & 1.54\end{array}$ $\begin{array}{lllllllllll}0.32 & 0.533 & 0.05 & 22569 & 0.08 & 13636 . & 0.06 & 19047 & 0.93 & 0.05 & 1.43\end{array}$ $\begin{array}{llllllllllll}0.32 & 0.533 & 0.05 & 22569 & 0.06 & 16997 . & 0.06 & 19337 & 0.93 & 0.06 & 1.35\end{array}$ $\begin{array}{lllllllllll}0.31 & 0.533 & 0.05 & 22419, & 0.09 & 12005 . & 0.07 & 14369 & 0.82 & 0.04 & 1.43\end{array}$ $\begin{array}{llllllllllll}0.30 & 0.667 & 0.05 & 22569 & 0.09 & 11488 . & 0.07 & 14052 . & 0.81 & 0.04 & 1.47\end{array}$ $\begin{array}{lllllllllllll}0.29 & 0.533 & 0.05 & 22717 & 0.08 & 13780 . & 0.07 & 14144 . & 0.81 & 0.05 & 1.46\end{array}$ $\begin{array}{llllllllllll}0.29 & 0.400 & 0.05 & 22717 . & 0.06 & 16941 . & 0.06 & 19080 & 0.92 & 0.06 & 1.39\end{array}$ $\begin{array}{lllllllllll}0.31 & 0.133 & 0.05 & 22717 . & 0.07 & 14651 . & 0.05 & 20153 . & 0.95 & 0.05 & 1.44\end{array}$ $\begin{array}{lllllllllll}0.32 & 0.267 & 0.05 & 22717 . & 0.07 & 14651 . & 0.06 & 18337 & 0.91 & 0.05 & 1.44\end{array}$ $\begin{array}{lllllllllll}0.31 & 0.000 & 0.05 & 22569 & 0.03 & 13731 . & 0.06 & 17100 . & 0.38 & 0.05 & 1.42\end{array}$ $\begin{array}{llllllllllll}0.29 & 0.267 & 0.05 & 22569 & 0.08 & 12774 . & 0.07 & 16049 & 0.86 & 0.05 & 1.45\end{array}$ $\begin{array}{llllllllllll}0.27 & 0.400 & 0.05 & 22717 . & 0.08 & 12774 . & 0.05 & 19758 . & 0.94 & 0.05 & 1.48\end{array}$ $\begin{array}{lllllllllll}0.31 & 0.200 & 0.05 & 22569 . & 0.06 & 17572 . & 0.06 & 19566 . & 0.94 & 0.07 & 1.34\end{array}$ $\begin{array}{lllllllllll}0.30 & 0.200 & 0.05 & 22569 & 0.06 & 18520 . & 0.05 & 21392 & 0.98 & 0.07 & 1.32\end{array}$ $\begin{array}{llllllllllll}0.30 & 0.267 & 0.05 & 22569 & 0.05 & 20288 & 0.05 & 22931 . & 1.01 & 0.08 & 1.28\end{array}$ $\begin{array}{lllllllllll}0.29 & 0.400 & 0.05 & 22419 . & 0.07 & 16126 . & 0.05 & 21008 . & 0.97 & 0.06 & 1.34\end{array}$ $\begin{array}{llllllllllll}0.26 & 1.000 & 0.05 & 21963 . & 0.06 & 18389 & 0.06 & 18650 & 0.93 & 0.07 & 1.19\end{array}$
\end{abstract}


WELL NUMBER $=27$

FIELD : CERRO PRIETO

RANCE : FROM 3630 TO 3680

COMPUTED DATA IS AS BELON:

Tnf $=\quad 75.000$

RHOmf $=1.100$

PHIDC $=\quad 0.04$

PHINC $=\quad 0.29$

AN $=$

AM $=2.30$

RHCLY $=0.10$

TDEEP $=500.0$

$\mathrm{RSH}=1.50$

$\begin{array}{rr}\text { DEPTH } & \text { SP } \\ 3630 & -72 . \\ 3632 & -72 . \\ 3634 & -72 . \\ 3636 & -72 . \\ 3638 & -72 . \\ 3640 & -72 . \\ 3642 & -70 . \\ 3644 & -69 \\ 3646 & -69 . \\ 3648 & -66 . \\ 3650 & -64 . \\ 3652 & -64 . \\ 3654 & -63 . \\ 3656 & -64 . \\ 3659 & -65 . \\ 3660 & -65 . \\ 3662 & -65 . \\ 3664 & -65 . \\ 3666 & -64 . \\ 3668 & -64 . \\ 3670 & -65 . \\ 3672 & -64 . \\ 3674 & -64 . \\ 3676 & -64 . \\ 3678 & -63 . \\ 3680 & -60 . \\ & \end{array}$

TABLE 27-10'

Riff= 0.500
SP GR FHId FHIn Rt VSH PHIE

93. $0.270 .13 \quad 10.3 \quad 0.00 \quad 0.29$

$\begin{array}{llllll}94 . & 0.26 & 0.17 & 6.8 & 0.00 & 0.27\end{array}$

94. $0.26 \quad 0.16 \quad 6.6 \quad 0.00 \quad 0.28$

91. $0.290 .14 \quad 5.4 \quad 0.00 \quad 0.31$

$\begin{array}{lllllll}90 . & 0.30 & 0.14 & 5.2 & 0.00 & 0.33\end{array}$

91. $0.310 .15 \quad 45.2 \quad 0.00 \quad 0.34$

$\begin{array}{lllllll}90 . & 0.33 & 0.13 & 5.1 & 0.00 & 0.36\end{array}$

87. $0.320 .13 \quad 5.1 \quad 0.00 \quad 0.35$

91. $0.290 .19 \quad 3.5 \quad 0.00 \quad 0.31$

$\begin{array}{llllll}\text { 88. } & 0.30 & 0.20 & 1.6 & 0.00 & 0.32\end{array}$

$\begin{array}{llllll}91 . & 0.30 & 0.20 & 0.8 & 0.00 & 0.32\end{array}$

$\begin{array}{llllll}91 . & 0.30 & 0.19 & 0.8 & 0.00 & 0.32\end{array}$

$\begin{array}{llllll}91 . & 0.29 & 0.18 & 1.1 & 0.00 & 0.31\end{array}$

93. $0.290 .20 \quad 1.2 \quad 0.00 \quad 0.30$

$\begin{array}{llllll}91 . & 0.28 & 0.20 & 1.3 & 0.00 & 0.29\end{array}$

89. $0.28 \quad 0.19 \quad 0.90 .00 \quad 0.29$

$\begin{array}{llllll}\text { 85. } & 0.29 & 0.19 & 0.8 & 0.00 & 0.31\end{array}$

$\begin{array}{lllllll}87 . & 0.30 & 0.19 & 0.8 & 0.00 & 0.32\end{array}$

83. $0.290 .19 \quad 1.0 \quad 0.00 \quad 0.31$

$\begin{array}{llllll}87 . & 0.28 & 0.19 & 1.1 & 0.00 & 0.29\end{array}$

89. $0.26 \quad 0.19 \quad 1.1 \quad 0.00 \quad 0.27$

86. $0.290 .19 \quad 0.80 .00 \quad 0.31$

36. $0.290 .20 \quad 0.8 \quad 0.00 \quad 0.30$

87. $0.290 .21 \quad 0.7 \quad 0.00 \quad 0.30$

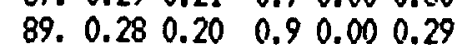

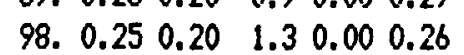

FHITD USHGR RWSP PPMSP RWAX PPMAX RWAD PPMD SW RMF

$\begin{array}{lllllllllll}0.29 & 0.667 & 0.05 & 21338 . & 0.23 & 3699 . & 0.61 & 1391 . & 0.28 & 0.01 & 1.80\end{array}$

$\begin{array}{lllllllllll}0.27 & 0.733 & 0.05 & 21338 & 0.15 & 6098 & 0.34 & 2468 . & 0.37 & 0.02 & 1.74\end{array}$

$\begin{array}{lllllllllll}0.28 & 0.733 & 0.05 & 21333 . & 0.16 & 5443 . & 0.34 & 2507 . & 0.37 & 0.02 & 1.76\end{array}$

$\begin{array}{lllllllllll}0.31 & 0.533 & 0.05 & 21328 . & 0.14 & 6241 . & 0.37 & 2267 & 0.35 & 0.02 & 1.74\end{array}$

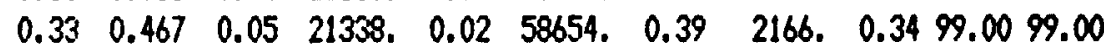

$\begin{array}{lllllllllll}0.34 & 0.533 & 0.05 & 21338 . & 1.05 & 797 . & 3.67 & 237 & 0.11 & 0.00 & 1.87\end{array}$

$\begin{array}{lllllllllllll}0.36 & 0.467 & 0.05 & 21106 . & 0.08 & 11060 . & 0.49 & 1710 . & 0.31 & 0.04 & 1.56\end{array}$

$\begin{array}{lllllllllll}0.35 & 0.267 & 0.05 & 20989 . & 0.08 & 11041 . & 0.46 & 1845 . & 0.32 & 0.04 & 1.53\end{array}$

$\begin{array}{lllllllllll}0.31 & 0.533 & 0.05 & 20870 . & 0.08 & 11360 . & 0.24 & 3677 . & 0.45 & 0.04 & 1.49\end{array}$

$\begin{array}{lllllllllll}0.32 & 0.333 & 0.05 & 20630 . & 0.08 & 11419 . & 0.11 & 7944 . & 0.65 & 0.04 & 1.43\end{array}$

$\begin{array}{lllllllllll}0.32 & 0.533 & 0.05 & 20386 . & 0.07 & 13636 . & 0.06 & 16989 & 0.92 & 0.05 & 1.32\end{array}$

$\begin{array}{lllllllllll}0.32 & 0.533 & 0.05 & 20386 . & 0.06 & 16997 . & 0.06 & 17246 . & 0.93 & 0.06 & 1.24\end{array}$

$\begin{array}{llllllllllll}0.31 & 0.533 & 0.05 & 20262 . & 0.08 & 12005 . & 0.07 & 12828 . & 0.81 & 0.04 & 1.32\end{array}$

$\begin{array}{lllllllllllll}0.30 & 0.667 & 0.05 & 20386, & 0.08 & 11488 . & 0.07 & 12546, & 0.30 & 0.04 & 1.36\end{array}$

$\begin{array}{lllllllllll}0.29 & 0.533 & 0.05 & 20509 . & 0.07 & 13780 . & 0.07 & 12628 . & 0.80 & 0.05 & 1.34\end{array}$

$\begin{array}{llllllllllll}0.29 & 0.400 & 0.05 & 20508 . & 0.06 & 16941 . & 0.06 & 17018 . & 0.92 & 0.06 & 1.27\end{array}$

$\begin{array}{lllllllllll}0.31 & 0.133 & 0.05 & 20508 . & 0.06 & 14651 . & 0.05 & 17972 . & 0.94 & 0.05 & 1.32\end{array}$

$\begin{array}{lllllllllll}0.32 & 0.267 & 0.05 & 20508 . & 0.06 & 14651 . & 0.06 & 16357 . & 0.90 & 0.05 & 1.32\end{array}$

$\begin{array}{lllllllllll}0.31 & 0.000 & 0.05 & 20386 . & 0.07 & 13731 . & 0.06 & 15257 . & 0.88 & 0.05 & 1.31\end{array}$

$\begin{array}{llllllllllll}0.29 & 0.267 & 0.05 & 20336 . & 0.07 & 12774 & 0.07 & 14322 & 0.85 & 0.05 & 1.34\end{array}$

$\begin{array}{llllllllllll}0.27 & 0.400 & 0.05 & 20508 . & 0.07 & 12774 . & 0.05 & 17620 & 0.93 & 0.05 & 1.37\end{array}$

$\begin{array}{llllllllllll}0.31 & 0.200 & 0.05 & 20386 . & 0.05 & 17572 . & 0.06 & 17450 . & 0.93 & 0.07 & 1.23\end{array}$

$\begin{array}{lllllllllll}0.30 & 0.200 & 0.05 & 20386 . & 0.05 & 18520 . & 0.05 & 19072 . & 0.97 & 0.07 & 1.21\end{array}$

$\begin{array}{lllllllllll}0.30 & 0.267 & 0.05 & 20386 . & 0.05 & 20288, & 0.05 & 20440 . & 1.00 & 0.08 & 1.11\end{array}$

$\begin{array}{llllllllllll}0.29 & 0.400 & 0.05 & 20262 . & 0.06 & 16126 . & 0.05 & 18731 . & 0.97 & 0.06 & 1.23\end{array}$

$\begin{array}{lllllllllllllll}0.26 & 1.000 & 0.05 & 19884 . & 0.05 & 18389 & 0.06 & 16635 . & 0.92 & 0.07 & 1.10\end{array}$ 
WELL MMBER $=27$

FIELD : CERRO PRIETO

RANGE : FROM 3630 TO 3680

COMPUTEN DATA IS AS BETOH

Tnf $=\quad 75.000$

$R H D i n f=1.100$

PHIDC $=\quad 0.04$

PHINC $=\quad 0.29$

AN $=\quad 1.00$

AMI $=2.50$

RWCLY $=0.10$

TDEEP $=500.0$

RSH $=1.50$

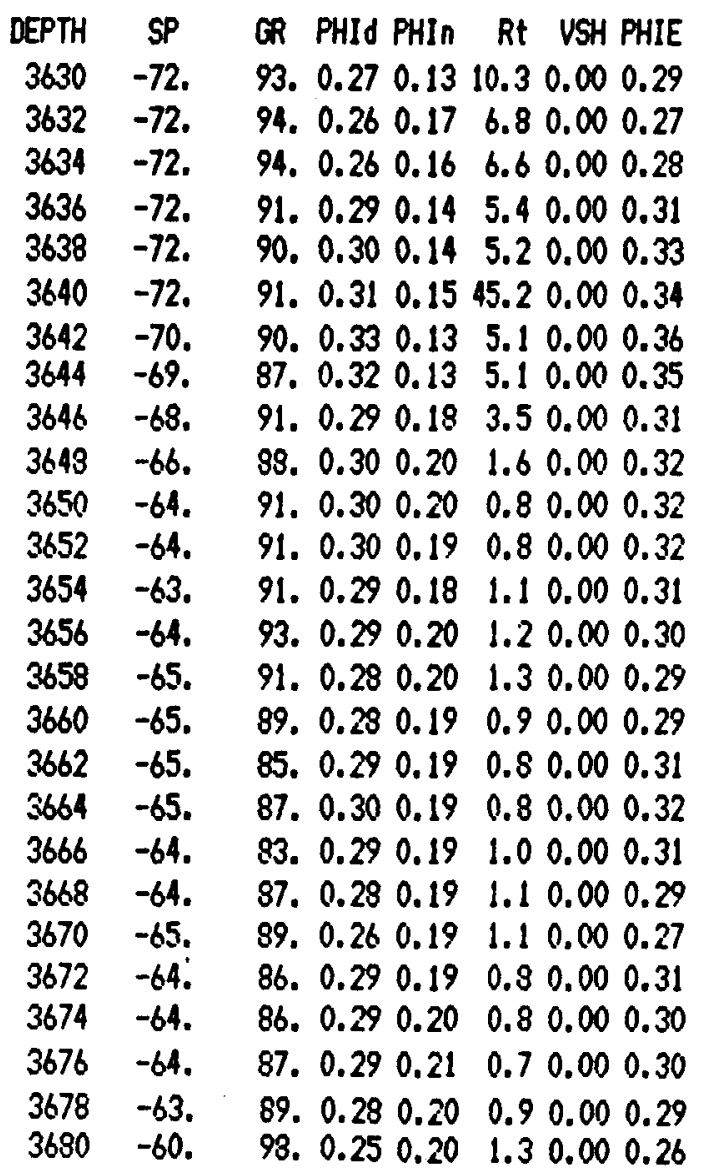

TABLE 27-11

TDEEP IS USED

PHITD USHGR RUSP PFMSP RHAX PPMAX RWAD PPMD SW RMF

$\begin{array}{lllllllllll}0.29 & 0.667 & 0.05 & 21338 & 0.23 & 3699 & 0.48 & 1774 . & 0.31 & 0.01 & 1.80\end{array}$

$\begin{array}{llllllllllll}0.27 & 0.733 & 0.05 & 21338 . & 0.15 & 6098 & 0.27 & 3229 & 0.42 & 0.02 & 1.74\end{array}$

$\begin{array}{lllllllllll}0.28 & 0.733 & 0.05 & 21338 . & 0.16 & 5443 . & 0.26 & 3277 & 0.42 & 0.02 & 1.76\end{array}$

$\begin{array}{lllllllllllll}0.31 & 0.533 & 0.05 & 21338 . & 0.14 & 6241 . & 0.30 & 2981 . & 0.39 & 0.02 & 1.74\end{array}$

$\begin{array}{lllllllllll}0.33 & 0.467 & 0.05 & 21338 . & 0.02 & 58654, & 0.31 & 2731, & 0.3899 .0099 .00\end{array}$

$\begin{array}{lllllllllll}0.34 & 0.533 & 0.05 & 21338 . & 1.05 & 797 . & 2.95 & 292 . & 0.12 & 0.00 & 1.87\end{array}$

$\begin{array}{llllllllllll}0.36 & 0.467 & 0.05 & 21106 . & 0.08 & 11060 & 0.40 & 2106 . & 0.34 & 0.04 & 1.56\end{array}$

$\begin{array}{lllllllllllll}0.35 & 0.267 & 0.05 & 20989 & 0.08 & 11041 . & 0.37 & 2289 & 0.35 & 0.04 & 1.53\end{array}$

$\begin{array}{llllllllllll}0.31 & 0.533 & 0.05 & 20870 . & 0.08 & 11360 . & 0.19 & 4712 . & 0.50 & 0.04 & 1.49\end{array}$

$\begin{array}{llllllllllll}0.32 & 0.333 & 0.05 & 20630 . & 0.08 & 11419 . & 0.09 & 10185 . & 0.72 & 0.04 & 1.43\end{array}$

$\begin{array}{llllllllllll}0.32 & 0.533 & 0.05 & 20386 . & 0.07 & 13636 . & 0.04 & 21909 . & 1.03 & 0.05 & 1.32\end{array}$

$\begin{array}{lllllllllllll}0.32 & 0.533 & 0.05 & 20386 . & 0.06 & 16997 . & 0.04 & 22219 . & 1.04 & 0.06 & 1.24\end{array}$

$\begin{array}{llllllllllll}0.31 & 0.533 & 0.05 & 20262 . & 0.08 & 12005 & 0.06 & 16606 . & 0.91 & 0.04 & 1.32\end{array}$

$\begin{array}{lllllllllllll}0.30 & 0.667 & 0.05 & 20386 . & 0.08 & 11488 . & 0.06 & 16275 . & 0.90 & 0.04 & 1.36\end{array}$

$\begin{array}{llllllllllll}0.29 & 0.533 & 0.05 & 20508 . & 0.07 & 13780 . & 0.06 & 16523 & 0.91 & 0.05 & 1.34\end{array}$

$\begin{array}{lllllllllllll}0.29 & 0.400 & 0.05 & 20508 . & 0.06 & 16941 . & 0.04 & 22294 . & 1.04 & 0.06 & 1.27\end{array}$

$\begin{array}{lllllllllllllll}0.31 & 0.133 & 0.05 & 20508 . & 0.06 & 14651 & 0.04 & 23353 . & 1.06 & 0.05 & 1.32\end{array}$

$\begin{array}{llllllllllll}0.32 & 0.267 & 0.05 & 20508 . & 0.06 & 14651 . & 0.05 & 21065 & 1.01 & 0.05 & 1.32\end{array}$

$\begin{array}{lllllllllllll}0.31 & 0.000 & 0.05 & 20386 . & 0.07 & 13731 . & 0.05 & 19800 . & 0.99 & 0.05 & 1.31\end{array}$

$\begin{array}{llllllllllllll}0.29 & 0.267 & 0.05 & 20386 & 0.07 & 12774, & 0.05 & 18737 . & 0.96 & 0.05 & 1.34\end{array}$

$\begin{array}{lllllllllllll}0.27 & 0.400 & 0.05 & 20503 . & 0.07 & 12774 . & 0.04 & 23515 . & 1.06 & 0.05 & 1.37\end{array}$

$\begin{array}{lllllllllllll}0.31 & 0.200 & 0.05 & 20336 . & 0.05 & 17572 . & 0.04 & 22670 . & 1.05 & 0.07 & 1.23\end{array}$

$\begin{array}{lllllllllllll}0.30 & 0.200 & 0.05 & 20386 . & 0.05 & 18520 . & 0.04 & 24823 . & 1.09 & 0.07 & 1.21\end{array}$

$\begin{array}{lllllllllll}0.30 & 0.267 & 0.05 & 20386 . & 0.05 & 20288 . & 0.04 & 26649 & 1.13 & 0.08 & 1.17\end{array}$

$\begin{array}{llllllllllll}0.29 & 0.400 & 0.05 & 20262 . & 0.06 & 16126 . & 0.04 & 24587 . & 1.09 & 0.06 & 1.23\end{array}$

$\begin{array}{llllllllllllllllll}0.26 & 1.000 & 0.05 & 19884 & 0.05 & 18399 & 0.04 & 22436 . & 1.06 & 0.07 & 1.10\end{array}$ 
WELL NUMBER $=27$

FIELD : CERRO HRIETO

RANGE : FROM 4174 TO 4194

TABLE 27-12'

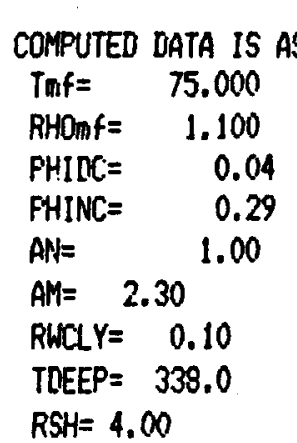

\begin{tabular}{|c|c|c|c|c|c|c|c|c|c|c|c|c|c|c|c|}
\hline DEPTH & $S P$ & GR & id PHIn & IE & ITD & $\mathrm{GR}$ & RWSP & $P$ & RHAX & & RHAL & & SH & RMF & \\
\hline 4174 & -60 & 95 & & 2.70 .00 & 0.26 & 0.286 & 0.05 & 28704. & 0.12 & 11236. & 0.12 & 11356. & 0.66 & 0.04 & \\
\hline 4176 & -62. & 97. & .15 & 1.20 .000 .24 & 0.24 & 0.571 & 0.05 & 29208. & 0.07 & 20866. & 0.05 & 33450 . & 1.06 & 0.08 & \\
\hline 4178 & -64. & 100. & 0.16 & $00 \quad 0.23$ & 0.23 & 1.000 & 0.05 & 29704. & 0.08 & 17509. & 0.05 & 33133. & 1.05 & 0.06 & 1.68 \\
\hline 4180 & -65 & & 20.14 & $1.20 .00 \quad 0.23$ & 0.23 & 0.429 & 0.05 & 29948. & 0.07 & 20287. & 0.04 & 36730. & 1.10 & 0.07 & 1.66 \\
\hline 4182 & 65. & 99. & 0.250 .16 & 1.20 .000 .26 & 0.26 & 0.857 & 0.05 & 29948. & 0.08 & 16661. & 0.06 & 25899. & 0.94 & 0.06 & \\
\hline 4184 & -66 . & 94. & 0.240 .16 & $1.20 .00 \quad 0.25$ & 0.25 & 0.143 & 0.05 & 30191. & 0.08 & 16661. & 0.05 & 29059. & 0.99 & 0.06 & 1.79 \\
\hline 4186 & -65. & 93. & 0.260 .16 & 1.20 .000 .28 & 0.28 & 0.000 & 0.05 & 29948. & 0.08 & 16983. & 0.06 & 24322. & 0.91 & 0.06 & 1.74 \\
\hline 4188 & -65. & 95. & 0.250 .16 & $1.20 .00 \quad 0.26$ & 0.26 & 0.286 & 0.05 & 29948. & 0.08 & 177 & 0.06 & 25071. & 0.92 & .06 & .72 \\
\hline 4190 & -63. & 95. & 0.230 .16 & $\begin{array}{lll}1.5 & 0.00 & 0.24\end{array}$ & 0.24 & 0.286 & 0.05 & 29457. & 0.07 & 15845. & 0.06 & 25302. & 0.94 & .06 & .67 \\
\hline 4192 & -61. & 95. & 0.190 .16 & 1.10 .000 .19 & 0.19 & 0.286 & 0.05 & 28957. & 0.08 & 17125. & 0.03 & 63074. & 1.41 & .06 & .55 \\
\hline 194 & -55 & 95. & 0.160 .16 & 30.000 .16 & 0.16 & 0.286 & 0.05 & 27410. & 0.12 & 00 & 0.05 & 31205. & 1.06 & .04 & \\
\hline
\end{tabular}


WELL NUMBER $=27$

FIELD : CERRO PRIETO

RANGE : FROM 4174 TO 4194

TABLE 27-13'

COMPUTED DATA IS AS BELON: $\quad \operatorname{Rmf}=0.500$ TDEEP IS USED

$\begin{array}{lc}\text { Tmf }= & 75.000 \\ \text { RHOnf }= & 1.100 \\ \text { PHIDC }= & 0.04 \\ \text { PHINC }= & 0.29 \\ \text { AN }= & 1.00 \\ \text { AH }=2.30 & 2.30 \\ \text { RWCLY }= & 0.10 \\ \text { TDEEP }= & 450.0 \\ \text { RSH }=4.00\end{array}$

RSH $=4.00$

\begin{tabular}{|c|c|c|c|c|c|c|c|c|c|c|c|c|c|c|}
\hline DEPTH & SP & PHId PHIn & VSH PHIE & PHITD & VSHGR & RHSP & PFTSP & RWAX & PPNAX & RWA & PPMD & SW & RMF & \\
\hline 4174 & -60. & 95. 0.2 & .26 & 0.26 & 0.286 & 0.05 & 21963. & 0.09 & 11286. & 0.12 & 8379. & 0.64 & 0.04 & 1.35 \\
\hline 4176 & -62. & 230.15 & 1.20 .00 & 0.24 & 0.571 & 0.05 & 22268. & 0.05 & 20866. & 0.05 & 24436. & 1.04 & 0.08 & 1.20 \\
\hline 4178 & -64. & 220.16 & $\begin{array}{lll}1.3 & 0.00 & 0.23\end{array}$ & 0.23 & 1.000 & 0.05 & 22569. & 0.06 & 17509. & 0.05 & 24206. & 1.03 & 0.07 & 1.34 \\
\hline 4180 & -65. & 96. & 1.20 .00 & 0.23 & 0.429 & 0.05 & 22717. & 0.05 & 20287. & 0.04 & 26909. & 1.08 & 0.08 & 1.32 \\
\hline 4182 & -65 & 99 & & 0.26 & 0.857 & 0.05 & 22717. & 0.06 & 16661. & 0.06 & 18964. & 0.92 & 0.06 & 1.39 \\
\hline 4184 & -66. & .240 .16 & 1.20 .000 .25 & 0.25 & 0.143 & 0.05 & 22864 . & 0.06 & 16661. & 0.05 & 21255. & 0.97 & 0.06 & 1.43 \\
\hline 4186 & -65. & 0.260 .16 & 1.20 .000 .28 & 0.28 & 0.000 & 0.05 & 22717. & 0.06 & 16883. & 0.06 & 17819. & 0.90 & 0.06 & 1.39 \\
\hline 4189 & -65 . & 0.16 & 1.20 .000 .26 & 0.26 & 0.286 & 0.05 & 22717. & 0.06 & 17719. & 0.06 & 18363. & 0.91 & 0.07 & 1.37 \\
\hline 4190 & -63. & 95. & $\begin{array}{lll}1.5 & 0.00 & 0.24\end{array}$ & 0.24 & 0.286 & 0.05 & 22419. & 0.07 & 15845. & 0.06 & 18893. & 0.93 & 0.06 & 1.34 \\
\hline 4192 & -61. & .190 .16 & 1.10 .000 .19 & 0.19 & 0.286 & 0.05 & 22116. & 0.06 & 1712 & 0.03 & 45813. & 1.39 & 0.06 & 1.25 \\
\hline 4194 & 55. & & 0.000 .16 & 0.16 & 0.286 & 0.05 & 21178. & 0.09 & & 0.05 & 22810. & 1.03 & 0.04 & .21 \\
\hline
\end{tabular}


WELL NUMBER $=27$

FIELD : CERPO PRIETO

RANGE : FROM 4174 TO 4194

COMPUTED DATA IS AS BELOW: RARf $=0.500$

Tinf $=75.000$

RHOMf $=1.100$

PHIDC $=0.04$

PHINC $=\quad 0.29$

$A N=\quad 1.00$

AM $=2.00$

RHCLY $=0.10$

TDEEP $=450.0$

RSH $=4.00$
TABLE 27-14'

TDEEP IS USED

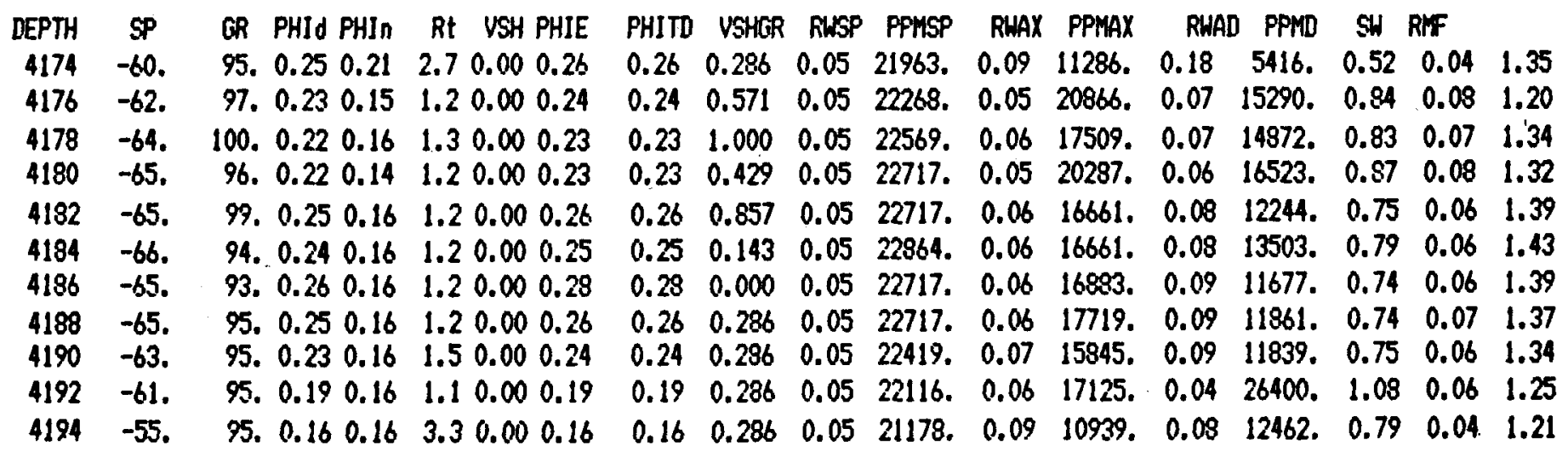




\section{LOCATION:}

The calculation of the coordinates uses as origin the coordinates for the center of Unit No. 1 of the Cerro Prieto Geothermal Power Plant; coordinates are referred to the rehabilitation system of the Irrigation District of the Department of Hydraulic Resources.

$$
\begin{aligned}
& X=-17.435 .27 \mathrm{~m}\left(\begin{array}{ll}
57 & 201.6^{\prime}
\end{array}\right) \\
& Y=-1998.57 \mathrm{~m}\left(6556.9^{\prime}\right)
\end{aligned}
$$

Rotary table elevation $3.36 \mathrm{~m}\left(11.0^{\prime}\right)$ above ground level.

The well is located approximately $210.5 \mathrm{~m}\left(690.6^{\prime}\right)$ to the northeast of well M-9 and $303.3 \mathrm{~m}$ (995.1') northwest of well M-34.

DRILLING $66.0 \mathrm{~cm}(26 " \emptyset)$ HOLE

Started drilling at $21: 00 \mathrm{~h}$ on April 3, 1968, drilling with $66.0 \mathrm{~cm}$ (26"Ø) bit to a depth of $9.64 \mathrm{mbgl}$ (31.6').

cleaned hole and pulled bit and drill string out to the surface.

\section{CEMENTING $55.9 \mathrm{~cm}\left(22^{\prime \prime} \emptyset\right)$ CASING}

Prepared and ran in $55.9 \mathrm{~cm}\left(22^{\prime \prime} \emptyset\right)$, grade B, $95.07 \mathrm{~kg} / \mathrm{m}(65.24 \mathrm{lb} / \mathrm{ft})$ conductor casing equipped with a Baker brand centralizer down to a depth of $8.64 \mathrm{mbgl}\left(28.3^{\prime}\right)$.

With equipment and personnel from the contractor company, cemented the conductor casing with 100 sacks of cement [4000 kg $(8818.4 \mathrm{lb}$ ], portland Ga110 well-type cement, by means of direct cementing. The cement came out to the surface.

After the cement had set, installed surface connections.

DRILLING $50.8 \mathrm{~cm}\left(20^{\prime \prime} \emptyset\right)$ HOLE

Ran in $38.1 \mathrm{~cm}\left(1^{\prime \prime} \emptyset\right)$ bit and drill string to $7.64 \mathrm{mbg} 1$ (25.1'), reached the top of the cement, drilled and continued drilling to a depth of 181.64 mbgl (595.9'), circulated at the bottom and pulled the drill string out to the surface.

Ran in $50.8 \mathrm{~cm}\left(20^{\prime \prime \emptyset)}\right.$ hole opener with $38.1 \mathrm{~cm}$ (15"ø) guide bit and drill string, reamed the hole to a depth of $181.64 \mathrm{mbgl}$ (595.9'). 
Conditioned mud and hole, pulled bit and drill string out to the surface.

CEMENTING $40.6 \mathrm{~cm}\left(16^{\prime \prime} \emptyset\right)$ CASING

Prepared and ran in $40.6 \mathrm{~cm}$ (16"Ø) grade $\mathrm{H}-40,96.72 \mathrm{~kg} / \mathrm{m}(65 \mathrm{lb} / \mathrm{ft})$

rtsc, 8 threads per inch casing down to a depth of $180.62 \mathrm{mbgl}$ (592.6'). It was equipped with a guide shoe, float collar, 7 centralizers, and a hammer-1ock stop ring.

With equipment and personnel from the Halliburton Company, cemented the $40.6 \mathrm{~cm}$ (16"Ø) casing with 600 sacks of portland Gallo type $V$ cement. The cement came out to the surface.

After the cement had set, removed surface connections, cut $55.9 \mathrm{~cm}$ (22" $\emptyset$ ) and $40.6 \mathrm{~cm}\left(16^{\prime \prime} \emptyset\right)$ casing at $0 \mathrm{~m}\left(0^{\prime}\right)$ and at $0.35 \mathrm{~m}\left(1.15^{\prime}\right)$ above the bottom of the cellar.

\section{INSTALLING $40.6 \mathrm{~cm}\left(16^{\prime \prime} \emptyset\right)$ WELL-HEAD}

With equipment and personnel from Timex, welded with inside and outside beads the $40.6 \mathrm{~cm}$ (16"Ø) F.I.P. series 600, 2000 API well-head to $7.6 \mathrm{~cm}$ (3"Ø) double threadable side outlet.

Installed $40.6 \mathrm{~cm}\left(16^{\prime \prime \emptyset)}\right.$ Shaffer blowout preventer and surface connections.

HYDRAULIC TEST

Ran in $38.1 \mathrm{~cm}\left(15^{\prime \prime} \emptyset\right)$ bit followed by twelve $17.1 \mathrm{~cm}\left(6-3 / 4^{\prime \prime} \emptyset\right) \mathrm{drill}$ collars and $11.4 \mathrm{~cm}\left(4-1 / 2^{\prime \prime} \emptyset\right)$ fh drill string to a depth of $169.64 \mathrm{mbgl}\left(556.6^{\prime}\right)$, where the top of the cement was reached.

Closed blowout preventer, applied pressure, and satisfactorily tested 40.6 $\mathrm{cm}$ (16"Ø) casing, cementing job, and surface connections with a pressure of 70 $\mathrm{kg} / \mathrm{cm}^{2}$ (1000 psig) for $15 \mathrm{~min}$.

\section{DRILLING $38.1 \mathrm{~cm}\left(15^{\prime \prime} \emptyset\right)$ HOLE}

With $38.1 \mathrm{~cm}\left(15^{\prime \prime} \emptyset\right)$ bit and drill string, drilled through cement plug collar, and shoe, continued drilling to a depth of $1038.64 \mathrm{mbgl}$ (3407.6'):

\section{TECHNICAL LOGS}

With equipment and personnel from the Commission, obtained temperature logs $\mathrm{T}-1$ and $\mathrm{T}-2$ from 646.64 to $1036.64 \mathrm{mbg} 1$ (2121.5' to $3401.0^{\prime}$ ) with bottom temperatures of $87.7^{\circ}$ and $90^{\circ} \mathrm{C}\left(190.0^{\circ}\right.$ and $\left.194^{\circ} \mathrm{F}\right)$, respectively. 
DRILLING $38.1 \mathrm{~cm}\left(15^{\prime \prime} \emptyset\right)$ HOLE, CONTINUED

With $38.1 \mathrm{~cm}\left(15^{\prime \prime} \emptyset\right)$ bit and drill string, continued drilling from 1038.64 to $1054.64 \mathrm{mbgl}\left(3407.6^{\prime}\right.$ to $\left.3460.1^{\prime}\right)$ and pulled the drill string out to the surface.

\section{THERMAL AND ELECTRICAL LOGS}

With equipment and personnel from the Comnission, obtained temperature logs $\mathrm{T}-3$ from 646.64 to $1046.64 \mathrm{mbg} 1$ (2121.5' to $3433.8^{\prime}$ ), $\mathrm{T}-4, \mathrm{~T}-5$, and $\mathrm{T}-6$ from 496.64 to $1046.64 \mathrm{mbgl}\left(1629.4^{\prime}\right.$ to $\left.3433.8^{\prime}\right)$, with maximum bottom temperatures of $103^{\circ}, 130^{\circ}, 136^{\circ}$, and $108^{\circ} \mathrm{C}\left(217.4^{\circ}, 266^{\circ}, 276.8^{\circ}\right.$, and $\left.226.4^{\circ} \mathrm{F}\right)$, respectively

Ran in $38.1 \mathrm{~cm}\left(15^{\prime \prime} \emptyset\right)$ bit and drill string to the bottom, conditioned mud and hole, pulled drill string out to the surface.

With equipment and personnel from the Pan Geo Atlas Company, obtained electrical $\log$ from 1057.9 to 182.9 mbrt (3470' to 600'); did not obtain calibration $\log$ due to a defect in the probe.

With equipment and personnel from the Commission, obtained temperature logs T-7 and T-8 from a depth of 496.64 to $1046.54 \mathrm{mbgl}$ (1629.4' to $3433.5^{\prime}$ ') and from 496.64 to $1049.64 \mathrm{mbgl}$ ( $1629.4^{\prime}$ to $3443.7^{\prime}$ ), with maximum bottom temperatures of $139^{\circ}$ and $146^{\circ} \mathrm{C}\left(282.2^{\circ}\right.$ and $\left.294.8^{\circ} \mathrm{F}\right)$, respectively.

Conditioned mud and hole; with equipment and personnel from the Pan Geo Atlas Company, obtained microlog and calibration $\log$ from 1057.9 to $182.9 \mathrm{mbrt}$ (3470' to $\left.600^{\prime}\right)$.

During the drilling the following inclinations were obtained:

\begin{tabular}{ccc}
$(\mathrm{mbg} 1)$ & $(\mathrm{ft})$ & $\begin{array}{c}\text { Inclination } \\
\text { (degrees) }\end{array}$ \\
\hline 291.64 & 956.8 & $0^{\circ} 30^{\prime}$ \\
496.64 & 1629.4 & $0^{\circ} 30^{\prime}$ \\
660.64 & 2167.4 & $1^{\circ} 0^{\prime}$ \\
754.64 & 2475.8 & $0^{\circ} 15^{\prime}$ \\
904.64 & 2967.9 & $0^{\circ} 15^{\prime}$ \\
976.64 & 3204.2 & $0^{\circ} 15^{\prime}$
\end{tabular}




\section{CEMENTING $29.9 \mathrm{~cm}(11-3 / 4 " \emptyset)$ CASING}

Prepared and ran in $29.9 \mathrm{~cm}\left(11-3 / 4^{\prime \prime \emptyset) ~ g r a d e ~} \mathrm{~J}-55,69.9 \mathrm{~kg} / \mathrm{m}(47 \mathrm{lb} / \mathrm{ft})\right.$ and $\mathrm{N}-80,89.3 \mathrm{~kg} / \mathrm{m}(60 \mathrm{lb} / \mathrm{ft})$ buttress thread casing to a depth of 1040.70 mbg1 (3414.3'). It was equipped with guide shoe and Larnik brand float collar, 19 centralizers, and 2 hammer-lock stop rings.

With equipment and personnel from the Halliburton Company, cemented the $29.9 \mathrm{~cm}$ (11-3/4'Ø) casing with 784 sacks of Victor class G special cement mixed with special high-temperature additives. The excess cement came out to the surface.

After the cement had set, released internal pressure, removed blowout preventer and cut $29.9 \mathrm{~cm}\left(11-3 / 4^{\prime \prime} \emptyset\right)$ casing $0.5 \mathrm{~cm}\left(1.64^{\prime}\right)$ below the $40.6 \mathrm{~cm}$ (16" $\emptyset$ ) well-head flange. Washed the annular space between $40.6 \mathrm{~cm}\left(16^{\prime \prime} \emptyset\right)$ and $29.9 \mathrm{~cm}\left(11-3 / 4^{\prime \prime} \emptyset\right)$ casing to a depth of $5.8 \mathrm{mbgl}$ (19.0'), installed telescoping

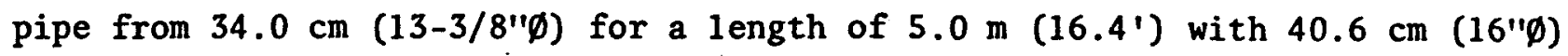
adapter flange to $30.5 \mathrm{~cm}\left(12^{\prime \prime} \emptyset\right), 30.5 \mathrm{~cm}\left(12^{\prime \prime} \emptyset\right)$ master valve, blowout preventer, and surface connections.

HYDRAULIC TEST

Ran in $27.0 \mathrm{~cm}\left(10-5 / 8^{\prime \prime} \emptyset\right)$ bit followed by six $17.2 \mathrm{~cm}\left(6-3 / 4^{\prime \prime} \emptyset\right) \mathrm{dril}$ collars and $11.4 \mathrm{~cm}\left(4-1 / 2^{\prime \prime} \emptyset\right)$ drill string to a depth of $1028.31 \mathrm{mbg} 1$ (3373.6'), where the top of the cement was reached. Displaced the mud column by water, washing the well completely.

Closed blowout preventer, applied pressure, satisfactorily tested the 29.9 $\mathrm{cm}\left(11-3 / 4^{\prime \prime} \emptyset\right)$ casing, cementing job, and surface connections with a pressure of $56 \mathrm{~kg} / \mathrm{cm}^{2}$ (800 psig) for $30 \mathrm{~min}$.

\section{FIRINGS}

With equipment and personnel from the Pan Geo Atlas Company, carried out firings with disintegrating guns in the interval from 829.94 to $918.34 \mathrm{mbg} 1$ (2722.9' to $3012.9^{\prime}$ ) with 1376 detonating charges.

\section{X-RAY LOG}

With equipment and personnel from the Conam Inspection Company, obtained $x$-ray $\log$ of the $40.6 \mathrm{~cm}\left(16^{\prime \prime} \emptyset\right)$ well-head weld with satisfactory results. 
Pulled drill string out to the surface, disconnecting pipe by pipe.

\section{COMPLETION}

The construction of this well was considered completed when the $30.5 \mathrm{~cm}$ (12"Ø) master valve was closed at 21:00 $\mathrm{h}$ on May 21, 1968. 


\section{PRODUCTIVE LIFE}

\section{INDUCING OPERATION}

Started sounding with American Heist equipment, 75-liter cylindrical bailer on July 18, 1968; succeeding in inducing it, having bailed the water column November 18, 1968, through a $7.3 \mathrm{~cm}\left(2-7 / 8^{\prime \prime} \emptyset\right)$ line and regulated $5.1 \mathrm{~cm}$ (2"甲) valve.

\section{DEVELOPMENT AND PRODUCTIVE LIFE}

Developed the well through $14.0,14.6,15.2,15.9$, and $16.5 \mathrm{~cm}\left(5-1 / 2^{\prime \prime}\right.$, 5-3/4", 6", 6-1/4", and 6-1/2" Ø) orifices, later during the years 1969, 1970, 1971, and 1972, through 6.5, 7.6, and 10.2 (2", 3". and 4") orifices with pressures of 21.1 to $7.0 \mathrm{~kg} / \mathrm{cm}^{2}$ (300 to $100 \mathrm{psig}$ ).

In March 1973 the well was developed through $12.1,17.8$, and $22.9 \mathrm{~cm}$ (4-3/4", 7", and 9") cones flowing to the plant through a side line on March $12,1973$.

A decrease in the pressure was observed from January 1974; it died out on March 27, 1974, and the well had to wait for repair, probably due to encrustations.

Compiled

Raul Rivera Olguin
Reviewed:

(signed)

Engineer Rene de Leon Botello

SUPERINTENDENT OF WELL DRILLING

Approved ;

Engineer Bernardo Dominguez Aguirre GENERAL SUPERINTENDENT 
SP-GAMMA RAY OVERLAYS WELL 29 


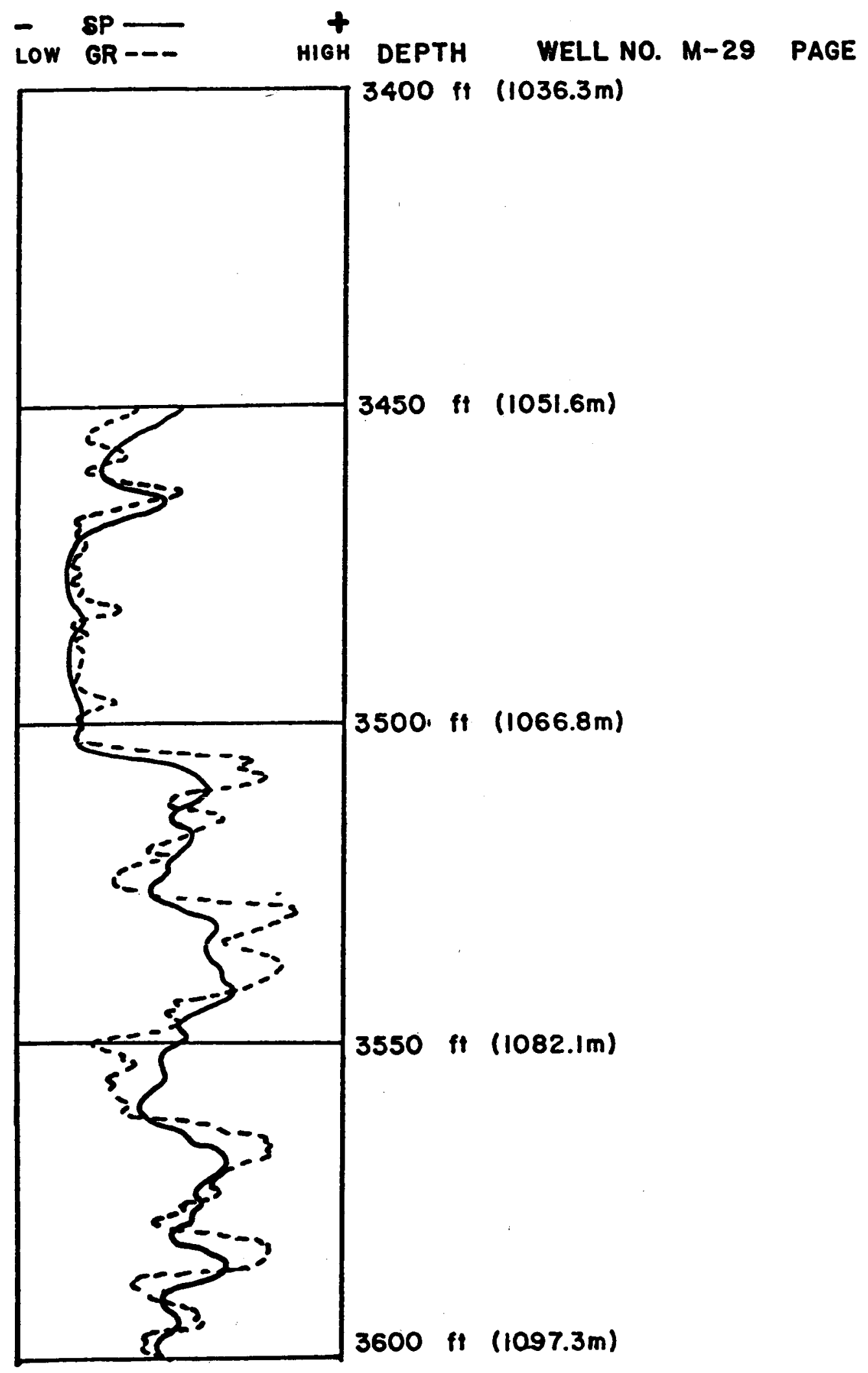

Fig. D-14. SP-Gamma Ray Overlay. 


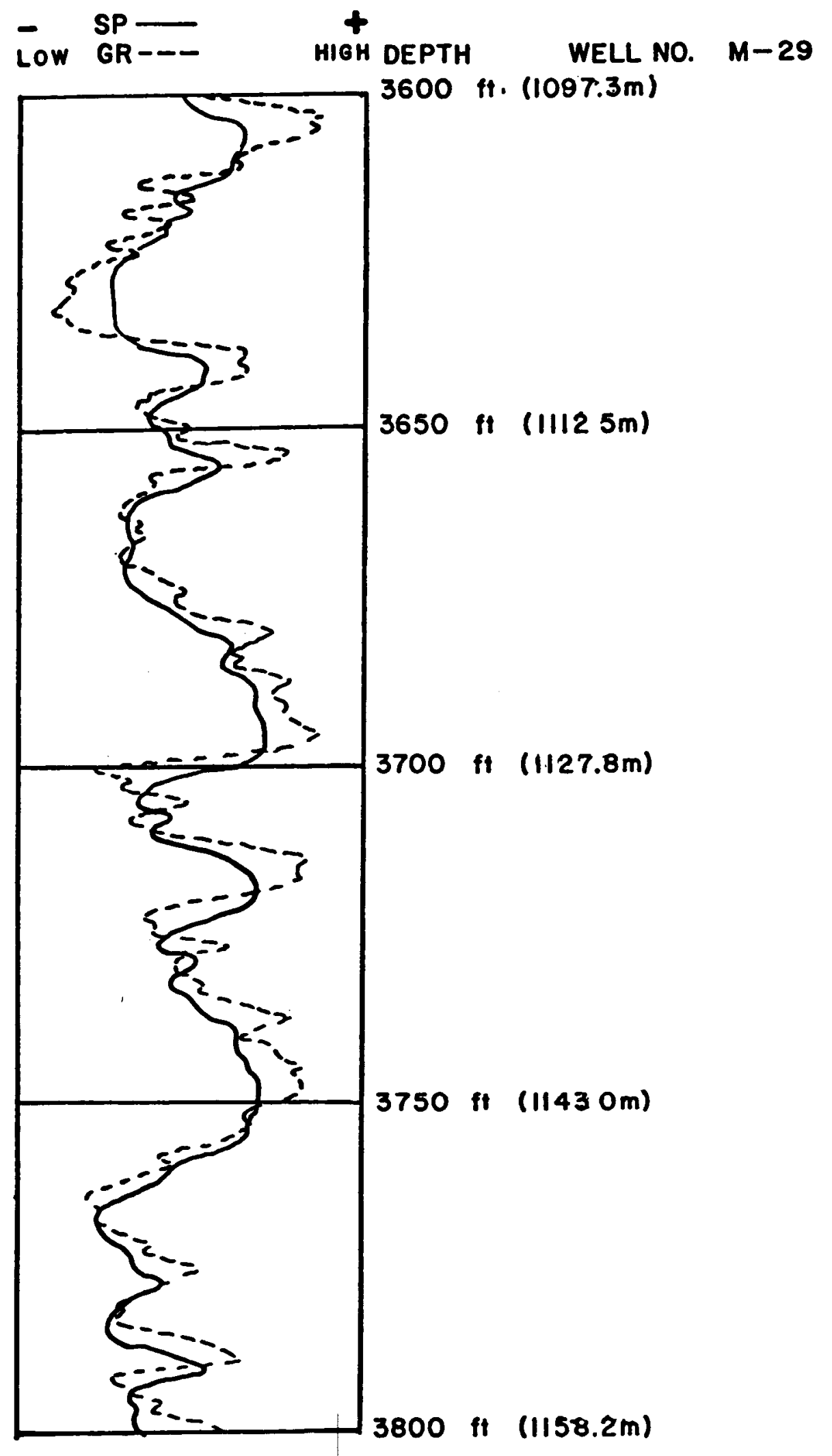

Fig. D-15. SP-Gamma Ray Overlay. 


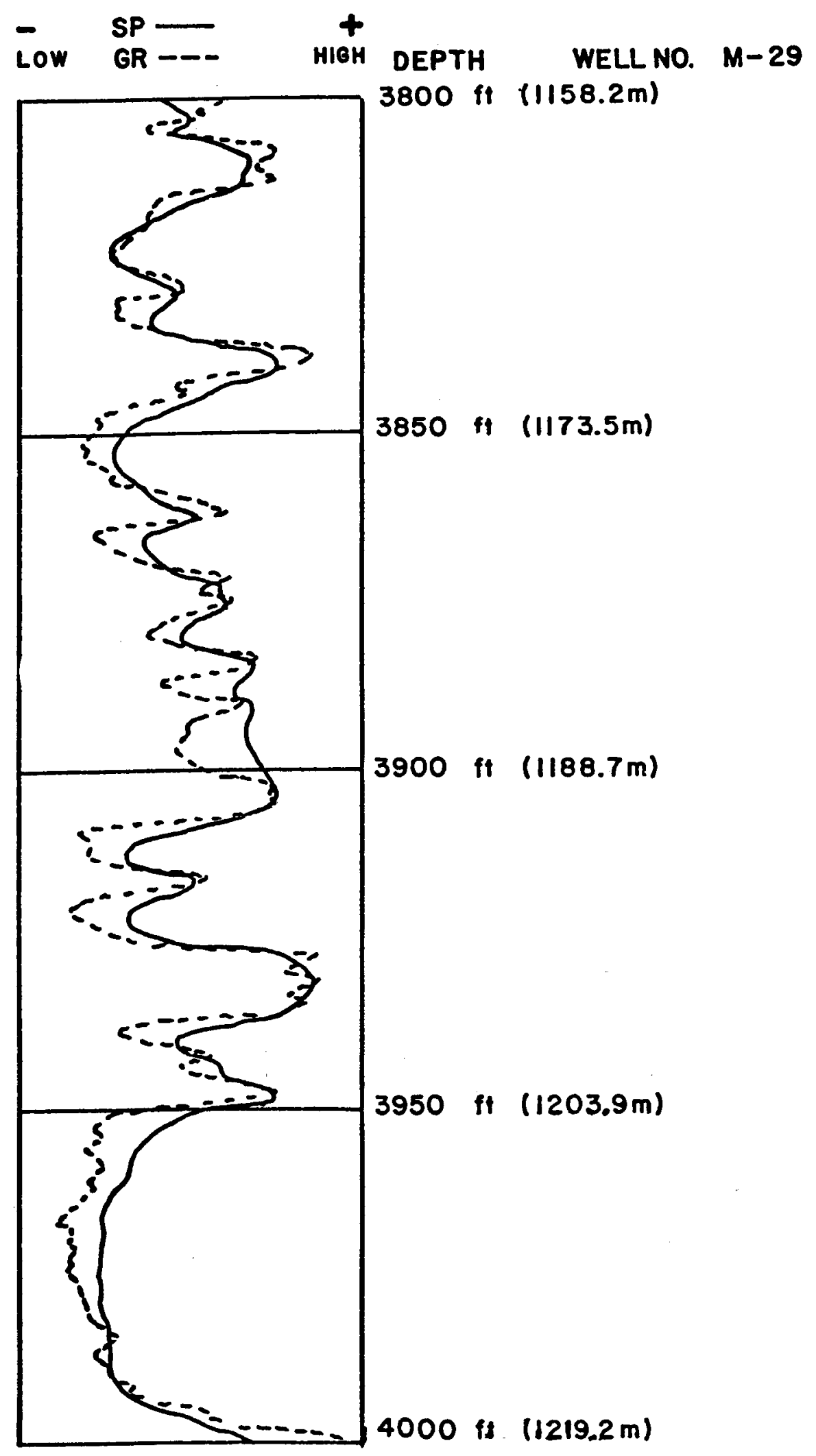

Fig. D-16. SP-Gamma Ray Overlay. 


\section{COMPUTED RESULTS WELL 29}

WELL NUMBER $=2$ ?

FIELD : CERRO PRIETO COMPUTED DATA IS AS BELON:
Tof $=$
75.000
RHOmf $=1.100$
PHIDC $=0.05$
FHINC $=0.35$
$A N=$ 1.00
$A M=2.30$
RWCLY $=0.10$
TDEEP $=205.0$

$\mathrm{RB} B \mathrm{H}=1.60$

\begin{tabular}{|c|c|c|c|}
\hline DEFTH & $S P$ & CR PHId PHIn & Rt USH PHIE \\
\hline 3476 & -60 & 48. 0.300 .35 & $\begin{array}{lll}1.2 & 0.17 & 0.29\end{array}$ \\
\hline 3478 & -59. & 50.0 .200 .27 & 1.30 .230 .19 \\
\hline 3430 & -58. & 53. 0.220 .27 & 1.40 .170 .21 \\
\hline 3482 & -57 & 61.0 .190 .32 & $0.6 \quad 0.43 \quad 0.17$ \\
\hline 3434 & -55. & 47. $0.23 \quad 0.27$ & 1.30 .130 .22 \\
\hline 3436 & -5.9. & 49. 0.230 .28 & $1.0 \quad 0.170 .22$ \\
\hline 3488 & $-5 \%$ & 51. 0.230 .29 & $\begin{array}{lll}1.3 & 0.20 & 0.22\end{array}$ \\
\hline 3490 & -59 & $\begin{array}{lll}51 . & 0.22 & 0.28\end{array}$ & 1.30 .200 .21 \\
\hline 3492 & -58. & 49. $0.21 \quad 0.25$ & $\begin{array}{lll}1.5 & 0.13 & 0.20\end{array}$ \\
\hline $34 \geqslant 4$ & -58 & $51.0 .22 \quad 0.26$ & $\begin{array}{lll}0.7 & 0.13 & 0.21\end{array}$ \\
\hline $34: 6$ & -57. & $80.0 .22 \quad 0.32$ & $\begin{array}{llll}1.1 & 0.33 & 0.20\end{array}$ \\
\hline 3498 & -55. & $50.0 .22 \quad 0.30$ & 1.30 .270 .21 \\
\hline 3500 & -57. & 52. $0.25 \quad 0.27$ & $1.50 .07 \quad 0.25$ \\
\hline 3502 & -57. & 47. $0.24 \quad 0.27$ & $\begin{array}{lll}1.6 & 0.10 & 0.24\end{array}$ \\
\hline 3504 & -58. & $\begin{array}{llll}70 . & 0.20 & 0.27\end{array}$ & 1.50 .230 .19 \\
\hline
\end{tabular}

TABLE 29-1

0.300
FHITD USHCR RWSP PPMSP RHAX PPMAX RWAD PPMD SW RMF

$\begin{array}{lllllllllll}0.32 & 0.043 & 0.05 & 55769 . & 0.05 & 47481 . & 0.08 & 29162 . & 0.72 & 0.10 & 1.91\end{array}$

$\begin{array}{lllllllllll}0.22 & 0.130 & 0.05 & 55282, & 0.04 & 59530, & 0.04 & 73714 . & 1.03 & 0.13 & 1.70\end{array}$

$\begin{array}{lllllllllll}0.24 & 0.261 & 0.05 & 54539 & 0.04 & 77744 . & 0.05 & 53771 . & 0.93 & 0.19 & 1.41\end{array}$

$\begin{array}{lllllllllll}0.23 & 0.609 & 0.05 & 54044 . & 0.04 & 75851 & 0.02 & 189300 . & 1.45 & 0.19 & 1.37\end{array}$

$\begin{array}{lllllllllll}0.24 & 0.000 & 0.05 & 53038 . & 0.04 & 74301 . & 0.05 & 55497 . & 0.97 & 0.19 & 1.26\end{array}$

$\begin{array}{lllllllllll}0.25 & 0.087 & 0.05 & 54539 . & 0.06 & 44350 . & 0.04 & 68070 . & 1.04 & 0.09 & 1.81\end{array}$

$\begin{array}{llllllllllll}0.25 & 0.174 & 0.05 & 54775 . & 0.07 & 37963 . & 0.05 & 51932 . & 0.91 & 0.08 & 1.94\end{array}$

$\begin{array}{llllllllllll}0.24 & 0.174 & 0.05 & 54775 . & 0.08 & 30870 . & 0.05 & 54926 . & 0.93 & 0.06 & 2.02\end{array}$

$\begin{array}{llllllllllll}0.22 & 0.087 & 0.05 & 54291 . & 0.07 & 35548 . & 0.04 & 58428 . & 0.98 & 0.07 & 1.90\end{array}$

$\begin{array}{llllllllllll}0.23 & 0.174 & 0.05 & 54291 . & 0.04 & 64346 . & 0.02 & 137077 . & 1.43 & 0.14 & 1.57\end{array}$

$\begin{array}{lllllllllll}0.25 & 0.565 & 0.05 & 53555 . & 0.06 & 44155 . & 0.04 & 60808 . & 0.93 & 0.09 & 1.74\end{array}$

$\begin{array}{lllllllllll}0.25 & 0.130 & 0.05 & 52557 . & 0.04 & 61491 . & 0.05 & 53819 . & 0.91 & 0.14 & 1.41\end{array}$

$\begin{array}{lllllllllll}0.26 & 0.217 & 0.05 & 53558 . & 0.04 & 69112 . & 0.06 & 33773 . & 0.85 & 0.16 & 1.44\end{array}$

$\begin{array}{lllllllllll}0.25 & 0.000 & 0.05 & 53559 . & 0.04 & 70385 . & 0.07 & 38082 . & 0.83 & 0.17 & 1.43\end{array}$

$\begin{array}{lllllllllll}0.22 & 1.000 & 0.05 & 53300 . & 0.04 & 57783 & 0.04 & 58165 . & 0.94 & 0.13 & 1.63\end{array}$ 
WELL NUMBER $=29$

FIELD : CERRO FRIETO

FANGE : FROM 3476 TO 3504

Inf $=75.000$

RHOmf $=1.100$

FHIIC $=0.05$

PHINC $=\quad 0.35$

$A N=\quad 1.00$

$A M=2.30$

RHCLY $=0.10$

TDEEP $=350.0$

$R S H=1.60$

\begin{tabular}{|c|c|c|c|}
\hline DEFTH & SP & GR FHId PHIn & Rt USH PHIE \\
\hline 3476 & -60 & 48. 0.300 .35 & 1.20 .17 \\
\hline 3478 & -59. & 50. $0.20 \quad 0.27$ & 1.30 .23 \\
\hline 3480 & -58. & 53. $0.22 \quad 0.27$ & 0.17 \\
\hline 3482 & -57. & 61. 0.190 .32 & 0.43 \\
\hline 3484 & -55. & 47. $0.23 \quad 0.27$ & 1.30 .13 \\
\hline 3486 & -59. & 49. 0.230 .28 & 1.00 .17 \\
\hline 3488 & -59. & 51. 0.230 .29 & 1.30 .20 \\
\hline 3490 & -59. & 51.0 .220 .28 & 1.30 .20 \\
\hline 3492 & -58 & 49. 0.210 .25 & 1.50 .13 \\
\hline 3494 & -58. & 51.0 .220 .26 & 0.70 .13 \\
\hline 3496 & -57 & $\begin{array}{lll}60 . & 0.22 & 0.32\end{array}$ & 1.10 .33 \\
\hline 3498 & -55 & $\begin{array}{llll}50 . & 0.22 & 0.30\end{array}$ & 1.30 .27 \\
\hline 3500 & -57 & 0.250 .27 & 1.50 .07 \\
\hline 3502 & -57. & & \\
\hline
\end{tabular}

$\begin{array}{lllllllllllllllll}3504 & -53 . & 70 . & 0.20 & 0.27 & 1.5 & 0.23 & 0.19\end{array}$
TARLE 29-2'

TDEEP IS LISED
Rinf =

0.300
PHITD USHGR RWSF FPMSP RWAX PPMAX RWAD PFMD SW RMF

$\begin{array}{llllllllllll}0.32 & 0.043 & 0.04 & 32861 . & 0.03 & 47481 . & 0.08 & 16327 & 0.69 & 0.11 & 1.26\end{array}$

$\begin{array}{llllllllllll}0.22 & 0.130 & 0.04 & 32671 . & 0.03 & 59530 . & 0.04 & 40820 . & 1.00 & 0.15 & 1.07\end{array}$

$\begin{array}{llllllllllll}0.24 & 0.261 & 0.04 & 32480 . & 0.02 & 77744 . & 0.05 & 29930 . & 0.91 & 0.27 & 0.76\end{array}$

$\begin{array}{lllllllllll}0.23 & 0.609 & 0.05 & 32286 & 0.02 & 75851 & 0.02 & 104322 . & 1.41 & 0.26 & 0.74\end{array}$

$\begin{array}{llllllllllll}0.24 & 0.000 & 0.05 & 31391 . & 0.02 & 74901 . & 0.05 & 30860 . & 0.94 & 0.28 & 0.66\end{array}$

$\begin{array}{llllllllllllll}0.25 & 0.037 & 0.04 & 32480 . & 0.03 & 44350 . & 0.04 & 37771 . & 1.01 & 0.10 & 1.22\end{array}$

$\begin{array}{llllllllllll}0.25 & 0.174 & 0.04 & 32671 . & 0.04 & 37968 . & 0.05 & 29191 . & 0.88 & 0.08 & 1.34\end{array}$

$\begin{array}{lllllllllll}0.24 & 0.174 & 0.04 & 32671 . & 0.05 & 30870 . & 0.05 & 30525 . & 0.90 & 0.06 & 1.42\end{array}$

$\begin{array}{lllllllllll}0.22 & 0.037 & 0.04 & 32480 . & 0.04 & 35548 . & 0.04 & 32650 . & 0.95 & 0.08 & 1.33\end{array}$

$\begin{array}{llllllllllll}0.23 & 0.174 & 0.04 & 32480, & 0.02 & 64346 . & 0.02 & 75440 . & 1.39 & 0.18 & 0.96\end{array}$

$\begin{array}{lllllllllll}0.25 & 0.565 & 0.05 & 32286 & 0.03 & 44155 . & 0.04 & 3446 \% & 0.90 & 0.10 & 1.18\end{array}$

$\begin{array}{llllllllllll}0.25 & 0.130 & 0.05 & 31891 . & 0.03 & 61491 . & 0.05 & 30480 . & 0.83 & 0.18 & 0.88\end{array}$

$\begin{array}{lllllllllll}0.26 & 0.217 & 0.05 & 32286 & 0.02 & 69112 . & 0.06 & 21846 . & 0.82 & 0.21 & 0.85\end{array}$

$\begin{array}{lllllllllll}0.25 & 0.000 & 0.05 & 32286 . & 0.02 & 70385 . & 0.06 & 21504 . & 0.80 & 0.22 & 0.83\end{array}$

$\begin{array}{llllllllllll}0.22 & 1.000 & 0.04 & 32480 . & 0.03 & 57783 . & 0.04 & 33043 . & 0.91 & 0.15 & 1.05\end{array}$ 
WELL MMBER $=29$

FIED : CERRO PRIETO

RANCE : FRON 3476 TO 3504

COMPUTED DATA IS AS BELON:

TImf $=75.000$

RHOaf $=1.100$

PHIDC $=0.05$

PHINC $=\quad 0.35$

$A N=1.00$

AM $=2.30$

RUCLY $=0.10$

TDEEP $=450.0$

RSH $=1.60$

$\begin{array}{rr}\text { DEPTH } & \text { SP } \\ 3476 & -60 . \\ 3478 & -59 . \\ 3480 & -58 . \\ 3482 & -57 . \\ 3484 & -55 . \\ 3486 & -58 . \\ 3488 & -59 . \\ 3490 & -59 . \\ 3492 & -53 . \\ 3494 & -58 . \\ 3496 & -57 . \\ 3498 & -55 . \\ 3500 & -57 . \\ 3502 & -57 . \\ 3504 & -58 .\end{array}$

TABLE 29-3'

TDEEP IS USED
Raf= 0.300
GR PHId PHIn Rt VSH PHIE
48. $0.30 \quad 0.35 \quad 1.20 .17 \quad 0.29$
PHITD VSHGR RWSP PPNSP RWAX PPMAX RUAD PPND SW RHF
50. $0.20 \quad 0.27 \quad 1.3 \quad 0.230 .19$
$\begin{array}{llllllllllll}0.35 & 0.043 & 0.04 & 25595 & 0.02 & 47481 . & 0.11 & 9029 & 0.69 & 0.12 & 1.00\end{array}$
53. $0.22 \quad 0.27 \quad 1.40 .17 \quad 0.21$
$\begin{array}{lllllllllll}0.28 & 0.130 & 0.04 & 25476, & 0.02 & 59530 . & 0.06 & 18675 . & 0.99 & 0.18 & 0.81\end{array}$
61. $0.190 .32 \quad 0.6 \quad 0.43 \quad 0.17$
$\begin{array}{lllllllllll}0.27 & 0.261 & 0.04 & 25355 . & 0.02 & 77744 . & 0.07 & 15982 . & 0.9099 .0099 .00\end{array}$
47. $0.23 \quad 0.27 \quad 1.30 .130 .22$
$\begin{array}{llllllllllll}0.33 & 0.609 & 0.04 & 25233 . & 0.02 & 75851 . & 0.03 & 36789 . & 1.3999 .0099 .00\end{array}$
49. $0.230 .28 \quad 1.00 .170 .22$
$\begin{array}{lllllllllll}0.27 & 0.000 & 0.04 & 24985 . & 0.02 & 74901 . & 0.06 & 17972 . & 0.9399 .00 & 99.00\end{array}$
51. $0.230 .29 \quad 1.30 .200 .22$
$\begin{array}{lllllllllll}0.28 & 0.087 & 0.04 & 25355 . & 0.03 & 44350 . & 0.05 & 20907 . & 1.00 & 0.11 & 0.99\end{array}$
51. $0.220 .28 \quad 1.30 .20 \quad 0.21$
$\begin{array}{llllllllllll}0.30 & 0.174 & 0.04 & 25476, & 0.03 & 37968 . & 0.07 & 14657 . & 0.87 & 0.09 & 1.09\end{array}$
49. $0.21 \quad 0.25 \quad 1.50 .130 .20$
$\begin{array}{llllllllllll}0.29 & 0.174 & 0.04 & 25476 . & 0.04 & 30870 . & 0.07 & 15290 . & 0.89 & 0.07 & 1.18\end{array}$
$\begin{array}{lllllllllllll}0.25 & 0.087 & 0.04 & 25355 . & 0.03 & 35543 . & 0.06 & 18608 . & 0.94 & 0.08 & 1.09\end{array}$
51. $0.22 \quad 0.26 \quad 0.70 .13 \quad 0.21$
$\begin{array}{lllllllllllll}0.26 & 0.174 & 0.04 & 25355 & 0.02 & 64346 . & 0.03 & 45286 . & 1.37 & 0.22 & 0.69\end{array}$
60. $0.220 .32 \quad 1.10 .330 .20$
$\begin{array}{lllllllllll}0.33 & 0.565 & 0.04 & 25233, & 0.03 & 44155, & 0.08 & 12685 . & 0.89 & 0.11 & 0.95\end{array}$
$\begin{array}{llllllllllll}0.31 & 0.130 & 0.04 & 24985, & 0.02 & 61491 . & 0.08 & 12849 . & 0.87 & 0.21 & 0.63\end{array}$
50. $0.22 \quad 0.30 \quad 1.3 \quad 0.27 \quad 0.21$
$\begin{array}{llllllllllll}0.27 & 0.217 & 0.04 & 25233 . & 0.02 & 69112 & 0.07 & 14563 . & 0.81 & 0.28 & 0.56\end{array}$
52. $0.25 \quad 0.27 \quad 1.50 .07 \quad 0.25$
$\begin{array}{llllllllllll}0.27 & 0.000 & 0.04 & 25233 . & 0.02 & 70385 . & 0.03 & 13249 . & 0.79 & 0.30 & 0.53\end{array}$
$\begin{array}{lllllll} & 47 . & 0.24 & 0.27 & 1.6 & 0.10 & 0.24\end{array}$
70. $0.20 \quad 0.27 \quad 1.5 \quad 0.23 \quad 0.19$
$\begin{array}{llllllllllll}0.28 & 1.000 & 0.04 & 25355 & 0.02 & 57733 & 0.07 & 14539 & 0.90 & 0.17 & 0.80\end{array}$ 
WELLL NUMBER $=29$

FIELD : CERRO PRIETO

RANGE : FRON 3476 TO 3504

$\begin{array}{lc}\text { COMPUTED } & \text { DATA IS AS } \\ \text { Taf }= & 75.000 \\ \text { RHOmf }= & 1.100 \\ \text { PHIDC }= & 0.05 \\ \text { PHINC }= & 0.35 \\ \text { AN }= & 1.00 \\ \text { AM }= & 2.30 \\ \text { RHCLY }= & 0.10 \\ \text { TDEEP }= & 550.0 \\ \text { RSH }= & 1.60\end{array}$

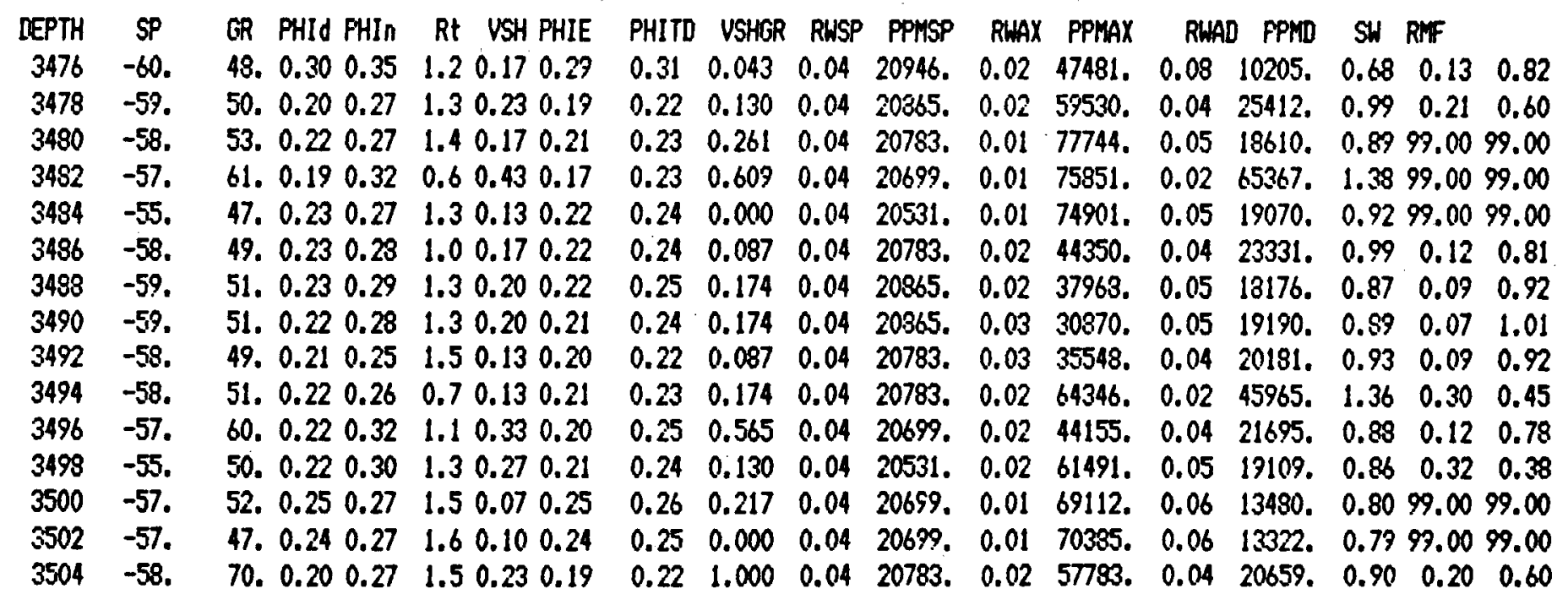

\section{TABLE 29-4'}

TDEEP IS USEU 
WELL MABER $=29$

FIELD : CERRO PRIETO

RANGE : FRON 3764 TO 3798

CORPUTED DATA IS AS BELON:

$T_{m f}=$

75.000

RHOnf $=1.100$

PHIDC $=\quad 0.05$

FHINC $=\quad 0.35$

AN $=$

$$
1.00
$$

$A M=2.30$

RHCLY $=0.10$

TDEEP $=242.0$

$\mathrm{RSH}=1.60$

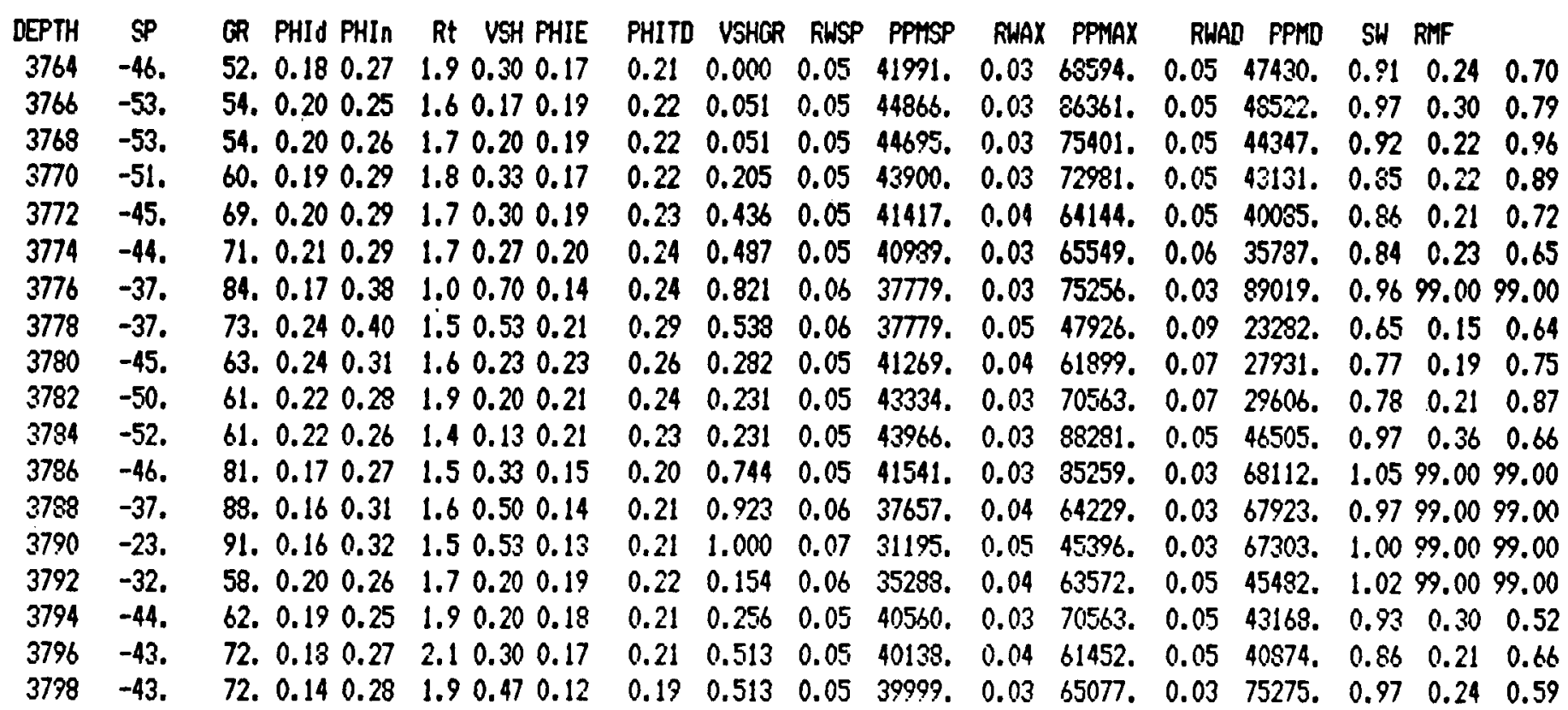

TARLE 27-5'

Raf $=\quad 0.300$ 
WELL NUMBER $=29$

FIELD : CERRO PRIETO

RANGE : FROM 3764 TO 3798

\section{CONPUTED DATA IS AS BELOW:}

Timf $=75.000$

RHOinf $=1.100$

FHIDC $=0.05$

PHINC $=\quad 0.35$

$A N=$

$A M=2.30$

RWCLY $=0.10$

TDEEP $=400.0$

RSH $=1.60$

$\begin{array}{rrllllll}\text { DEPTH } & \text { SP } & \text { GR } & \text { PHId } & \text { PHIn } & \text { Rt } & \text { VSH PHIE } \\ 3764 & -46 . & 52 . & 0.18 & 0.27 & 1.9 & 0.30 & 0.17 \\ 3766 & -53 . & 54 . & 0.20 & 0.25 & 1.6 & 0.17 & 0.1 \\ 3768 & -53 . & 54 . & 0.20 & 0.26 & 1.7 & 0.20 & 0.1 \\ 3770 & -51 . & 60 . & 0.19 & 0.29 & 1.8 & 0.33 & 0.17 \\ 3772 & -45 . & 69 . & 0.20 & 0.29 & 1.7 & 0.30 & 0.1 \\ 3774 & -44 . & 71 . & 0.21 & 0.29 & 1.7 & 0.27 & 0.2 \\ 3776 & -37 . & 84 . & 0.17 & 0.38 & 1.0 & 0.70 & 0.1 \\ 3778 & -37 . & 73 . & 0.24 & 0.40 & 1.5 & 0.53 & 0.21 \\ 3780 & -45 . & 63 . & 0.24 & 0.31 & 1.6 & 0.23 & 0.23 \\ 3782 & -50 . & 61 . & 0.22 & 0.28 & 1.9 & 0.20 & 0.21 \\ 3784 & -52 . & 61 . & 0.22 & 0.26 & 1.4 & 0.13 & 0.2 \\ 3786 & -46 . & 81 . & 0.17 & 0.27 & 1.5 & 0.33 & 0.15 \\ 3788 & -37 . & 88 . & 0.16 & 0.31 & 1.6 & 0.50 & 0.1 \\ 3790 & -23 . & 91 . & 0.16 & 0.32 & 1.5 & 0.53 & 0.13 \\ 3792 & -32 . & 58 . & 0.20 & 0.26 & 1.7 & 0.20 & 0.19 \\ 3794 & -44 . & 62 . & 0.19 & 0.25 & 1.9 & 0.20 & 0.18 \\ 3796 & -43 . & 72 . & 0.18 & 0.27 & 2.1 & 0.30 & 0.17 \\ 3798 & -43 . & 72 . & 0.14 & 0.28 & 1.9 & 0.47 & 0.12\end{array}$

TABLE $20-6^{\prime}$

Rinf $=$ 0.300

\begin{tabular}{|c|c|c|c|c|c|c|c|c|}
\hline מדו & VSHCR & RUSP & PPMSP & RWAX & PPMAX & & PPMD & SW RMF \\
\hline$\alpha$ & 0.000 & 0.05 & 26545. & 0.02 & 68594. & 0. & 693. & 0.87 \\
\hline .22 & 0.051 & 0.05 & 27706 . & 0.02 & 86361. & 0.04 & 27992. & \\
\hline .22 & 0.051 & 0.05 & 27706. & 0.02 & 75401. & 0.05 & 25802. & \\
\hline 22 & $\begin{array}{l}0.205 \\
0.436\end{array}$ & $\begin{array}{l}0.05 \\
0.05\end{array}$ & & & & $\begin{array}{l}0.05 \\
0.05\end{array}$ & $\begin{array}{l}25385 . \\
23544 .\end{array}$ & \\
\hline .24 & 0.487 & 0.05 & 26198. & 0.02 & 65549 & 0.08 & 21000. & \\
\hline 24 & 0.821 & 0.05 & & 0.02 & 75256 . & 0.03 & 53226 . & 0.92 \\
\hline & 0.538 & 0.05 & 24931. & 0.03 & 47926. & 0.08 & 14119. & 0.61 \\
\hline 2 & 0.282 & 0.05 & 26372. & 0.02 & 61899. & 0.07 & 16471. & 0.74 \\
\hline 2 & 0.231 & 0.05 & 27219. & 0.02 & 70563. & 0.07 & 17419. & 00 \\
\hline 23 & 0.231 & 0.05 & 27546. & 0.02 & 88281. & 0.05 & 27121. & 0.94 \\
\hline 2 & 0.744 & 0.05 & 26545. & 0.02 & 85259 . & 0.03 & 40134. & 1.01 \\
\hline .21 & 0.923 & 0.05 & 24931. & 0.02 & 64229 . & 0.03 & 40607. & 0.93 \\
\hline .2 & 1.000 & 0.06 & 22178. & 0.03 & 45396. & 0.03 & 40352. & .00 \\
\hline .22 & 0.154 & 0.05 & 23979. & 0.02 & 63572. & 0.05 & 26799 . & 0.96 \\
\hline & 0.256 & 0.05 & & 0.02 & 70563. & 0.05 & 25490 . & \\
\hline & 0.513 & 0.05 & & 0.02 & & 05 & & \\
\hline & & 0.05 & 26022. & 0.02 & 6507. & 0.03 & 45378. & 9.00 \\
\hline
\end{tabular}


WEL NUMBER $=29$

FIELD : CEFPO FRIETO

RANBE : FRON 3952 TO 3994

CONPUTED DATA IS AS BELON:

Taf $=75.000$

RHOanf $=1.100$

PHIDC $=0.05$

PHINC $=0.35$

$A N=\quad 1.00$

AH $=2.30$

RHCLY $=0.10$

TDEEP $=265.0$

RSH $=1.60$

$\begin{aligned} \text { IEPTH } & \text { SP } \\ 3952 & -42 . \\ 3954 & -49 . \\ 3956 & -51 . \\ 3958 & -52 . \\ 3960 & -53 . \\ 3962 & -57 . \\ 3964 & -61 . \\ 3966 & -61 . \\ 3963 & -61 . \\ 3970 & -61 . \\ 3972 & -61 . \\ 3974 & -62 . \\ 3976 & -61 . \\ 3978 & -61 . \\ 3990 & -60 . \\ 3982 & -58 . \\ 3984 & -58 . \\ 3996 & -53 . \\ 3988 & -57 . \\ 3990 & -56 . \\ 3992 & -53 . \\ 3994 & -47 .\end{aligned}$

CR PHId PHIn RT VSH PHIE

54. $0.20 \quad 0.24 \quad 2.20 .13 \quad 0.19$

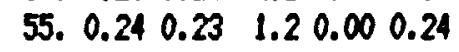

50. $0.20 \quad 0.21 \quad 2.5 \quad 0.03 \quad 0.20$

54. $0.20 \quad 0.24 \quad 2.6 \quad 0.13 \quad 0.19$

51. $0.24 \quad 0.23 \quad 1.90 .00 \quad 0.24$

$\begin{array}{llllll}51 . & 0.21 & 0.23 & 1.8 & 0.07 & 0.21\end{array}$

48. $0.20 \quad 0.22 \quad 2.1 \quad 0.07 \quad 0.20$

42. $0.18 \quad 0.20 \quad 2.5 \quad 0.07 \quad 0.18$

46. $0.190 .22 \quad 1.7 \quad 0.100 .19$

$\begin{array}{llllll}\text { 45. } & 0.22 & 0.24 & 0.9 & 0.07 & 0.22\end{array}$

45. $0.22 \quad 0.24 \quad 1.2 \quad 0.07 \quad 0.22$

44. $0.21 \quad 0.25 \quad 1.8 \quad 0.13 \quad 0.20$

47. $0.23 \quad 0.28 \quad 1.7 \quad 0.170 .22$

49. $0.25 \quad 0.34 \quad 1.80 .300 .24$

49. $0.21 \quad 0.27 \quad 1.90 .20 \quad 0.20$

$\begin{array}{llllll}\text { 54. } & 0.22 & 0.28 & 1.8 & 0.20 & 0.21\end{array}$

$\begin{array}{lllllll}59 . & 0.21 & 0.28 & 2.1 & 0.23 & 0.20\end{array}$

$\begin{array}{llllll}52 . & 0.24 & 0.28 & 1.9 & 0.13 & 0.23\end{array}$

54. $0.23 \quad 0.25 \quad 2.1 \quad 0.07 \quad 0.23$

$\begin{array}{llllll}58 . & 0.21 & 0.24 & 2.1 & 0.10 & 0.21\end{array}$

64. $0.190 .26 \quad 2.10 .230 .18$

78. $0.17 \quad 0.24 \quad 2.6 \quad 0.23 \quad 0.16$
TABLE 29-7'

0.300
PHITD USHGR RWSP PPISP RIAX PPMAX RUAD PPYD SH RHF

$\begin{array}{lllllllllllllll}0.21 & 0.333 & 0.05 & 37166 . & 0.03 & 77684 . & 0.06 & 31707 . & 0.8799 .0099 .00\end{array}$ $\begin{array}{llllllllllllllll}0.24 & 0.361 & 0.05 & 39570 . & 0.02 & 103408 . & 0.04 & 44286 . & 1.0599 .0099 .00\end{array}$ $\begin{array}{lllllllllllll}0.20 & 0.222 & 0.05 & 40260 . & 0.03 & 73159 . & 0.06 & 29110 . & 0.85 & 0.24 & 0.79\end{array}$ $\begin{array}{lllllllllll}0.21 & 0.333 & 0.05 & 40600 . & 0.03 & 79645, & 0.07 & 26021 . & 0.77 & 0.28 & 0.73\end{array}$ $\begin{array}{lllllllllllllll}0.24 & 0.250 & 0.05 & 40936 . & 0.02 & 97348 . & 0.07 & 26275 & 0.82 & 99.00 & 99.00\end{array}$ $\begin{array}{llllllllllll}0.22 & 0.250 & 0.05 & 42091, & 0.02 & 103064 . & 0.05 & 37426 . & 0.9299 .0099 .00\end{array}$ $\begin{array}{llllllllllll}0.21 & 0.167 & 0.05 & 43329 . & 0.03 & 69181 . & 0.05 & 36006 . & 0.90 & 0.17 & 1.37\end{array}$ $\begin{array}{lllllllllll}0.19 & 0.000 & 0.05 & 43329 & 0.03 & 82956 . & 0.05 & 38003 . & 0.91 & 0.22 & 1.20\end{array}$ $\begin{array}{llllllllllll}0.20 & 0.111 & 0.05 & 43329 & 0.03 & 62817 & 0.04 & 48679 . & 1.01 & 0.14 & 1.45\end{array}$ $\begin{array}{lllllllllll}0.23 & 0.083 & 0.05 & 43170 . & 0.02 & 116953 . & 0.03 & 69365 . & 1.21 & 99.0099 .00\end{array}$ $\begin{array}{lllllllllll}0.23 & 0.083 & 0.05 & 43170, & 0.02 & 89499 & 0.04 & 54592 . & 1.08 & 0.26 & 1.10\end{array}$ $\begin{array}{lllllllllll}0.22 & 0.056 & 0.05 & 43468, & 0.04 & 52183 . & 0.05 & 35560 . & 0.87 & 0.11 & 1.63\end{array}$ $\begin{array}{lllllllllll}0.25 & 0.139 & 0.05 & 43170 & 0.04 & 52912 . & 0.06 & 28808 . & 0.79 & 0.12 & 1.56\end{array}$ $\begin{array}{lllllllllll}0.28 & 0.194 & 0.05 & 43012 . & 0.03 & 65295 . & 0.09 & 18920 . & 0.63 & 0.15 & 1.41\end{array}$ $\begin{array}{lllllllllll}0.23 & 0.194 & 0.05 & 42713 . & 0.04 & 55351 . & 0.06 & 29706 . & 0.79 & 0.12 & 1.47\end{array}$ $\begin{array}{lllllllllll}0.24 & 0.333 & 0.05 & 42102 . & 0.04 & 50270 . & 0.07 & 28089 & 0.77 & 0.11 & 1.43\end{array}$ $\begin{array}{lllllllllll}0.23 & 0.472 & 0.05 & 42102 . & 0.03 & 62837 . & 0.07 & 26031 . & 0.73 & 0.15 & 1.28\end{array}$ $\begin{array}{lllllllllll}0.25 & 0.273 & 0.05 & 41951 . & 0.03 & 70108 . & 0.08 & 23324 . & 0.74 & 0.18 & 1.18\end{array}$ $\begin{array}{llllllllllll}0.24 & 0.333 & 0.05 & 41642 . & 0.04 & 55000 . & 0.07 & 24657 . & 0.77 & 0.13 & 1.32\end{array}$ $\begin{array}{lllllllllll}0.22 & 0.444 & 0.05 & 41329 & 0.03 & 67767 . & 0.06 & 29513 & 0.83 & 0.18 & 1.11\end{array}$ $\begin{array}{lllllllllll}0.21 & 0.611 & 0.05 & 40229 & 0.03 & 58774 & 0.06 & 34081 . & 0.83 & 0.15 & 1.07\end{array}$ $\begin{array}{lllllllllll}0.19 & 1.000 & 0.05 & 38225 & 0.04 & 46964, & 0.05 & 35364 & 0.84 & 0.12 & 0.97\end{array}$ 
FIELD : CERRO PRIETO

RANGE : FROM 3952 TO 3994

TARLE 29-8'

COMPUTED DATA IS AS BELOW:

Rmf $=$ 0.300

TDEEP IS USED

$\begin{array}{lc}\text { Tmf }= & 75.000 \\ \text { RHOmf }= & 1.100 \\ \text { PHIDC }= & 0.05 \\ \text { PHINC }= & 0.35 \\ \text { AN }= & 1.00 \\ \text { AM }=2.30 \\ \text { FWCLY }=0.10 \\ \text { TDEEP }=400.0 \\ \text { RSH }=1.60\end{array}$

\begin{tabular}{|c|c|c|c|c|c|c|c|c|c|c|c|c|c|c|}
\hline EPTH & $S P$ & FHId FHIn & VSH PHIE & PHITD & VSHGR & RWSP & PFMSP & RWAX & PPMAX & RWA & PPMD & SW & RMF & \\
\hline 3952 & -42. & 0.24 & 0.150. & 0.21 & 333 & 0.05 & 25844. & 0.02 & 77684. & 0.06 & 20346. & 0.84 & 99 & 9. \\
\hline 3954 & -49. & 240.23 & $\begin{array}{lll}1.2 & 0.00 & 0.24\end{array}$ & 0.24 & 0.361 & 0.05 & 27053. & 0.01 & 103408. & 0.04 & 28157. & 1.02 & & .00 \\
\hline 3956 & -51. & & 2.50 .030 .20 & 0.20 & 0.222 & 0.05 & 27383. & 0.02 & 73159. & 0.06 & 18652. & 0.83 & & 10 \\
\hline 3958 & -52 & 54. & 2.60 .130 & .21 & 0.333 & 0.05 & 27546. & 0.02 & 79645. & 0.07 & 16818. & 0.7 & & - \\
\hline 3960 & -53 & 51. 0.240 .23 & 1.90 .000 .24 & 0.24 & 0.250 & 0.05 & 27706. & 0.01 & 97348. & 0.07 & 16820. & 0.8 & & .00 \\
\hline 3962 & -57. & .23 & 1.8 & 0.22 & 0.250 & 0.04 & 28332. & 0.01 & 103064. & 0.05 & 24041. & 0 & & .00 \\
\hline 3964 & -61. & 40. & 2.1 & 0.21 & 0.167 & 0.04 & $2892 \%$ & 0.02 & 69181. & 0.05 & 23146. & 0.88 & 21 & 0.87 \\
\hline 3966 & -61. & 42. 0.180 .20 & 2.50 .070 .18 & 0.19 & 0.000 & 0.04 & 28929. & 0.02 & 2956. & 0.05 & 423. & 0.90 & 0.34 & 0.62 \\
\hline 3968 & -61. & & & 0.20 & 0.111 & 0.04 & 28929. & 0.02 & 62817. & 0.04 & 31234. & 0.99 & 0.17 & 0.96 \\
\hline & & & 0. & 0.23 & 0.083 & 0.04 & 28929. & 0.01 & 53. & 0.03 & 44677. & 1.19 & & YY. W0 \\
\hline 3712 & -61. & 45. & $1.20 .07 \quad 0.22$ & 0.23 & 0.083 & 0.04 & 28929. & 0.02 & 89499. & 0.04 & 35024. & 1.06 & .00 & 99.00 \\
\hline $\begin{array}{l}3974 \\
3976\end{array}$ & $\begin{array}{l}-62 . \\
-61 .\end{array}$ & $\begin{array}{lll}\text { 44. } & 0.21 & 0.25 \\
47 . & 0.23 & 0.28\end{array}$ & & $\begin{array}{l}0.22 \\
0.25\end{array}$ & $\begin{array}{l}0.056 \\
0.139\end{array}$ & $\begin{array}{l}0.04 \\
0.04\end{array}$ & & $\begin{array}{l}0.03 \\
0.03\end{array}$ & & & & & & $\begin{array}{l}1.14 \\
1.09\end{array}$ \\
\hline 3978 & -61. & 49. 0.250 .34 & $\begin{array}{llll}1.8 & 0.30 & 0.24\end{array}$ & 0.28 & 0.194 & 0.04 & 28929. & 0.02 & 65295. & 0.09 & 12548. & 0.62 & 19 & 0.93 \\
\hline 3980 & -60. & 0.210 .27 & 0.200 .20 & 0.23 & 0.194 & 0.04 & 28782. & 0.02 & 553 & 0.06 & 19463. & 0.77 & 0.14 & 1.02 \\
\hline & & & $\begin{array}{llll}1.8 & 0.20 & 0.21\end{array}$ & 0.24 & 0.333 & 0.04 & 2848 & 0.03 & 50270. & 0.07 & 18409. & 0.76 & 0.13 & 1.01 \\
\hline 3984 & -58. & $59 \cdot 0.210 .28$ & $\begin{array}{lll}2.1 & 0.23 & 0.20\end{array}$ & 0.23 & 0.472 & 0.04 & 28484. & 0.02 & 62837. & 0.07 & 17132. & 0.72 & 0.19 & 0.84 \\
\hline 3996 & - & 0.28 & 30.23 & 0.25 & 0.278 & 0.04 & 234 & 0.02 & & 0.08 & & 0.72 & 0.24 & 0.73 \\
\hline & & 0.230 .25 & 770.23 & 0.24 & 0.333 & 0.04 & 28332. & 0.02 & 0. & 0.07 & & 0.76 & 0.15 & 0.92 \\
\hline & -56. & 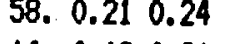 & 100.21 & 0.22 & 0.444 & 0.04 & 28178. & 0.02 & 67767. & 0.0 & & 0.81 & 0.23 & 0.69 \\
\hline 3992 & $\begin{array}{l}-53 \\
-47\end{array}$ & $\begin{array}{l}0.26 \\
0.24\end{array}$ & $\begin{array}{lll}2.1 & 0.23 & 0.18 \\
2.6 & 0.23 & 0.16\end{array}$ & 0.21 & 0.611 & 0.05 & 27706 . & 0.02 & 58774. & 0.0 & & 0.81 & 0.19 & 0.72 \\
\hline & & & 36 & & & & 26716 & 0.00 & . & 0.03 & 20767. & 0.02 & 0.14 & ). \\
\hline
\end{tabular}




\section{WELL MUMBER $=29$}

FIELD : CERRO PRIETO

RANGE : FROM 3952 TO 3994

\section{COMPUTED DATA IS AS BELOW:}

Tinf $=\quad 75.000$

RHOmf $=1.100$

PHIDC $=0.05$

PHINC $=\quad 0.35$

$A N=$ 1.00

$A M=2.30$

RHCLY $=0.10$

TIEEP $=400.0$

RSH $=1.60$

$\begin{array}{cc}\text { DEPTH } & \text { SP } \\ 3952 & -42 . \\ 3954 & -49 . \\ 3956 & -51 . \\ 3958 & -52 . \\ 3960 & -53 . \\ 3962 & -57 . \\ 3964 & -61 . \\ 3966 & -61 . \\ 3968 & -61 . \\ 3970 & -61 . \\ 3972 & -61 . \\ 3974 & -62 . \\ 3976 & -61 . \\ 3978 & -61 . \\ 3980 & -60 . \\ 3982 & -53 . \\ 3984 & -58 . \\ 3986 & -58 . \\ 3998 & -57 . \\ 3990 & -56 . \\ 3992 & -53 . \\ 3994 & -47 .\end{array}$

TABLE 29-9,

TDEEP IS USED
CR PHId PHIn RT USH PHIE

54. $0.20 \quad 0.24 \quad 2.2 \quad 0.13 \quad 0.19$

$\begin{array}{llllll}55 . & 0.24 & 0.23 & 1.2 & 0.00 & 0.24\end{array}$

50. $0.200 .21 \quad 2.50 .03 \quad 0.20$

$\begin{array}{llllll}54 . & 0.20 & 0.24 & 2.6 & 0.13 & 0.19\end{array}$ 51. $0.24 \quad 0.23 \quad 1.90 .00 \quad 0.24$ $\begin{array}{lllllll}\text { 51. } & 0.21 & 0.23 & 1.8 & 0.07 & 0.21\end{array}$

48. $0.20 \quad 0.22 \quad 2.1 \quad 0.07 \quad 0.20$

42. $0.18 \quad 0.20 \quad 2.5 \quad 0.07 \quad 0.18$

46. $0.190 .22 \quad 1.70 .100 .19$

45. $0.22 \quad 0.24 \quad 0.9 \quad 0.07 \quad 0.22$

$\begin{array}{llllll}\text { 45. } 0.22 & 0.24 & 1.2 & 0.07 & 0.22\end{array}$

44. $0.21 \quad 0.25 \quad 1.80 .13 \quad 0.20$

47. $0.23 \quad 0.28 \quad 1.70 .170 .22$

49. $0.25 \quad 0.34 \quad 1.80 .300 .24$

49. $0.21 \quad 0.27 \quad 1.90 .200 .20$

54. $0.220 .28 \quad 1.80 .20 \quad 0.21$

59. $0.210 .28 \quad 2.10 .23 \quad 0.20$

52. $0.24 \quad 0.28 \quad 1.90 .13 \quad 0.23$

54. $0.23 \quad 0.25 \quad 2.1 \quad 0.07 \quad 0.23$

58. $0.210 .24 \quad 2.10 .100 .21$

64. $0.190 .26 \quad 2.10 .23 \quad 0.19$

78. $0.170 .24 \quad 2.6 \quad 0.23 \quad 0.16$
PHITD USHCR RUSP PPHSP RWAX PPHAX RHAD PPTD SH RTF

$\begin{array}{llllllllll}0.21 & 0.333 & 0.06 & 20999 & 0.03 & 43399 & 0.06 & 20346 . & 0.9299 .0099 .00\end{array}$

$\begin{array}{llllllllll}0.24 & 0.361 & 0.05 & 22360 & 0.02 & 57505 & 0.04 & 28157 . & 1.11 & 99.0099 .00\end{array}$

$\begin{array}{lllllllllll}0.20 & 0.222 & 0.05 & 22767 . & 0.03 & 40911 . & 0.06 & 18652 . & 0.9099 .0099 .00\end{array}$

$\begin{array}{llllllllll}0.21 & 0.333 & 0.05 & 22969 & 0.03 & 44477 & 0.07 & 16818 . & 0.8199 .0099 .00\end{array}$

$\begin{array}{lllllllllllll}0.24 & 0.250 & 0.05 & 23169 . & 0.02 & 54188 . & 0.07 & 16820 . & 0.87 & 99.00 & 99.00\end{array}$

$\begin{array}{lllllllllll}0.22 & 0.250 & 0.05 & 23957 . & 0.02 & 57317 & 0.05 & 24041 . & 0.9799 .00 & 99.00\end{array}$

$\begin{array}{llllllllllll}0.21 & 0.167 & 0.05 & 24722 . & 0.03 & 38722 & 0.05 & 23146 . & 0.94 & 0.21 & 0.87\end{array}$

$\begin{array}{lllllllllll}0.19 & 0.000 & 0.05 & 24722 . & 0.03 & 46295 & 0.05 & 24423 & 0.96 & 0.34 & 0.62\end{array}$

$\begin{array}{llllllllllll}0.20 & 0.111 & 0.05 & 24722 . & 0.04 & 35215 & 0.04 & 31234 . & 1.06 & 0.17 & 0.96\end{array}$

$\begin{array}{lllllllllllll}0.23 & 0.083 & 0.05 & 24722 . & 0.02 & 64909 . & 0.03 & 44677 & 1.2799 .0099 .00\end{array}$

$\begin{array}{llllllllllllll}0.23 & 0.033 & 0.05 & 24722 . & 0.03 & 49886 . & 0.04 & 35024 . & 1.1499 .0099 .00\end{array}$

$\begin{array}{lllllllllll}0.22 & 0.056 & 0.05 & 24910 . & 0.04 & 29342 . & 0.05 & 23043 . & 0.91 & 0.13 & 1.14\end{array}$

$\begin{array}{lllllllllll}0.25 & 0.139 & 0.05 & 24722 . & 0.04 & 29745 . & 0.06 & 18751 . & 0.82 & 0.13 & 1.09\end{array}$

$\begin{array}{lllllllllll}0.28 & 0.194 & 0.05 & 24722 . & 0.04 & 36581 . & 0.09 & 12548 . & 0.86 & 0.19 & 0.93\end{array}$

$\begin{array}{lllllllllll}0.23 & 0.194 & 0.05 & 24533 . & 0.04 & 31094 . & 0.06 & 19463 . & 0.82 & 0.14 & 1.02\end{array}$

$\begin{array}{llllllllllllll}0.24 & 0.333 & 0.05 & 24151, & 0.04 & 28284 & 0.07 & 18409, & 0.81 & 0.13 & 1.01\end{array}$

$\begin{array}{lllllllllll}0.23 & 0.472 & 0.05 & 24151 . & 0.04 & 35226 . & 0.07 & 17132 . & 0.77 & 0.19 & 0.84\end{array}$

$\begin{array}{llllllllllll}0.25 & 0.273 & 0.05 & 24151 . & 0.03 & 39232 . & 0.08 & 15316 . & 0.77 & 0.24 & 0.73\end{array}$

$\begin{array}{lllllllllll}0.24 & 0.333 & 0.05 & 23957 . & 0.04 & 30900 . & 0.07 & 16117 . & 0.81 & 0.15 & 0.92\end{array}$

$\begin{array}{llllllllllll}0.22 & 0.444 & 0.05 & 23762 . & 0.03 & 37943 . & 0.06 & 19290 . & 0.37 & 0.23 & 0.69\end{array}$

$\begin{array}{lllllllllll}0.21 & 0.611 & 0.05 & 23169 & 0.04 & 32984, & 0.05 & 22533 . & 0.87 & 0.19 & 0.72\end{array}$

$\begin{array}{lllllllllll}0.19 & 1.000 & 0.06 & 21949 . & 0.05 & 26453 . & 0.05 & 23409 . & 0.88 & 0.14 & 0.70\end{array}$ 
WELL NUMBER $=29$

FIELD : CERRO PRIETO

RANGE : FROM 3952 TO 3994

COMFUTED DATA IS AS BELOW:

$\begin{array}{ll}\text { Tnf }= & 75.000 \\ \text { RHOmf }= & 1.100 \\ \text { FHIDC }= & 0.05 \\ \text { PHINC }= & 0.35 \\ \text { AN }= & 1.00 \\ \text { AM }=2.30 & \end{array}$

TDEEP $=265.0$

$\mathrm{RSH}=1.60$

$\begin{array}{rc}\text { DEPTH } & \text { SP } \\ 3952 & -42 . \\ 3954 & -49 . \\ 3956 & -51 . \\ 3958 & -52 . \\ 3960 & -53 . \\ 3962 & -57 . \\ 3964 & -61 . \\ 3966 & -61 . \\ 3969 & -61 . \\ 3970 & -61 . \\ 3972 & -61 . \\ 3974 & -62 . \\ 3976 & -61 . \\ 3978 & -61 . \\ 3980 & -60 . \\ 3982 & -58 . \\ 3934 & -58 . \\ 3996 & -58 . \\ 3988 & -57 . \\ 3990 & -56 . \\ 3992 & -53 . \\ 3994 & -47 .\end{array}$
Rinf $=\quad 0.500$

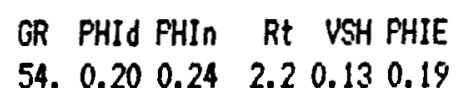
PHITD VSHGR RWSP PPMSP RWAX PPMAX RWAD FPMD SW RWF
$\begin{array}{lllllllllll}0.21 & 0.323 & 0.07 & 28728 . & 0.05 & 43399 & 0.06 & 31707 . & 0.3799 .00 & 99.00\end{array}$ $\begin{array}{llllllllllllll}0.24 & 0.361 & 0.06 & 31528 . & 0.04 & 57505 . & 0.04 & 44286 . & 1.16 & 99.00 & 99.00\end{array}$ 55. $0.24 \quad 0.23 \quad 1.20 .00 \quad 0.24$ 50. $0.200 .21 \quad 2.5 \quad 0.03 \quad 0.20$ $\begin{array}{lllllllllll}0.20 & 0.222 & 0.06 & 32337 . & 0.05 & 40911 . & 0.06 & 29110 . & 0.94 & 0.24 & 0.79\end{array}$ 54. $0.200 .24 \quad 2.60 .130 .19$ $\begin{array}{llllllllllll}0.21 & 0.333 & 0.06 & 32736 . & 0.04 & 44477 . & 0.07 & 26021 . & 0.94 & 0.28 & 0.73\end{array}$ 51. $0.24 \quad 0.23 \quad 1.90 .00 \quad 0.24$ $\begin{array}{llllllllll}0.24 & 0.250 & 0.06 & 33138 . & 0.04 & 54185 . & 0.07 & 26275, & 0.3099 .0099 .00\end{array}$ 51. $0.210 .23 \quad 1.8 \quad 0.07 \quad 0.21$ 48. $0.20 \quad 0.22 \quad 2.1 \quad 0.07 \quad 0.20$ $\begin{array}{llllllllllll}0.22 & 0.250 & 0.06 & 34599 & 0.04 & 57317 . & 0.05 & 37426 & 1.01 & 99.0099 .00\end{array}$ $\begin{array}{llllllllllll}0.21 & 0.167 & 0.05 & 36124 . & 0.05 & 38722 . & 0.05 & 36006 . & 0.97 & 0.17 & 1.37\end{array}$ 42. $0.18 \quad 0.20 \quad 2.50 .07 \quad 0.18$ 46. $0.190 .22 \quad 1.7 \quad 0.10 \quad 0.19$ $\begin{array}{lllllllllll}0.19 & 0.000 & 0.05 & 36124, & 0.04 & 46295 . & 0.05 & 33003 & 0.93 & 0.22 & 1.20\end{array}$ $\begin{array}{lllllllllll}0.20 & 0.111 & 0.05 & 36124 . & 0.05 & 35215 & 0.04 & 43679 . & 1.09 & 0.14 & 1.45\end{array}$ $\begin{array}{llllllllllllll}0.23 & 0.083 & 0.05 & 36001 & 0.03 & 64909 . & 0.03 & 69965 . & 1.31 & 99.0099 .00\end{array}$ 45. $0.220 .24 \quad 0.90 .07 \quad 0.22$ 45. $0.22 \quad 0.24 \quad 1.2 \quad 0.07 \quad 0.22$ 44. $0.21 \quad 0.25 \quad 1.80 .13 \quad 0.20$ $\begin{array}{lllllllllll}0.23 & 0.083 & 0.05 & 36001 . & 0.04 & 49836 . & 0.04 & 54592 . & 1.17 & 0.26 & 1.10\end{array}$ $\begin{array}{lllllllllll}0.22 & 0.056 & 0.05 & 36373 . & 0.06 & 29342, & 0.05 & 35560 . & 0.93 & 0.11 & 1.63\end{array}$ 47. $0.23 \quad 0.28 \quad 1.70 .17 \quad 0.22$ 49. $0.25 \quad 0.34 \quad 1.80 .30 \quad 0.24$ $\begin{array}{lllllllllll}0.25 & 0.139 & 0.05 & 36001 . & 0.06 & 29745 . & 0.06 & 28808 & 0.35 & 0.12 & 1.56\end{array}$ $\begin{array}{lllllllllll}0.28 & 0.194 & 0.05 & 35878 . & 0.05 & 36581, & 0.09 & 18920, & 0.67 & 0.15 & 1.41\end{array}$ 49. $0.21 \quad 0.27 \quad 1.90 .20 \quad 0.20$ 54. $0.22 \quad 0.28 \quad 1.80 .200 .21$ $\begin{array}{lllllllllll}0.23 & 0.194 & 0.05 & 35506 . & 0.06 & 31094 & 0.06 & 29706, & 0.85 & 0.12 & 1.47\end{array}$ $\begin{array}{lllllllllll}0.24 & 0.333 & 0.05 & 34752 . & 0.07 & 28284 & 0.07 & 28089 . & 0.84 & 0.11 & 1.43\end{array}$ 59. $0.210 .28 \quad 2.1 \quad 0.23 \quad 0.20$ 52. $0.24 \quad 0.28 \quad 1.90 .13 \quad 0.23$ 54. $0.23 \quad 0.25 \quad 2.10 .07 \quad 0.23$ $\begin{array}{llllllllllll}0.23 & 0.472 & 0.05 & 34752 . & 0.05 & 35226 . & 0.07 & 26031 . & 0.79 & 0.15 & 1.28\end{array}$ $\begin{array}{lllllllllll}0.25 & 0.278 & 0.05 & 34637 . & 0.05 & 39232 . & 0.08 & 23324 . & 0.80 & 0.18 & 1.18\end{array}$ $\begin{array}{llllllllllll}0.24 & 0.333 & 0.06 & 34259 & 0.06 & 30900 . & 0.07 & 24657 & 0.84 & 0.13 & 1.32\end{array}$ 58. $0.210 .24 \quad 2.10 .100 .21$ $\begin{array}{lllllllllll}0.22 & 0.444 & 0.06 & 33378 . & 0.05 & 37943 . & 0.06 & 29513 . & 0.90 & 0.18 & 1.11\end{array}$ 64. $0.190 .26 \quad 2.1 \quad 0.23 \quad 0.18$ $\begin{array}{lllllllllll}0.21 & 0.611 & 0.06 & 32618 . & 0.06 & 32984 . & 0.06 & 34081 . & 0.90 & 0.15 & 1.07\end{array}$ 78. $0.17 \quad 0.24 \quad 2.6 \quad 0.23 \quad 0.16$ $\begin{array}{lllllllllllll}0.19 & 1.000 & 0.06 & 30264 . & 0.07 & 26453 & 0.05 & 35364 . & 0.92 & 0.12 & 0.97\end{array}$ 
WELL NUMBER $=29$

FIELD : CERRO FRIETO

RANGE : FROY 4070 TO 4096

COMPUTED DATA IS AS BELON:

$\begin{array}{ll}\text { Timf }= & 75.000 \\ \text { RHOnf }= & 1.100 \\ \text { PHIDC }= & 0.05 \\ \text { PHINC }= & 0.35 \\ \text { AN }= & 1.00 \\ \text { AM=. 2.30 }\end{array}$

$A M=.2 .30$

RMCLY $=0.10$

TDEEP $=282.0$

RSH $=1.60$

$\begin{array}{rrllllll}\text { IEPTH } & \text { SP } & \text { GR } & \text { PHId PHIn } & \text { RT } & \text { VSH PHIE } \\ 4070 & -47 . & 53 . & 0.22 & 0.29 & 1.0 & 0.23 & 0.21 \\ 4072 & -54 . & 67 . & 0.22 & 0.30 & 1.6 & 0.27 & 0.21 \\ 4074 & -55 . & 74 . & 0.22 & 0.29 & 1.5 & 0.23 & 0.21 \\ 4076 & -57 . & 59 . & 0.23 & 0.27 & 1.4 & 0.13 & 0.22 \\ 4078 & -58 . & 62 . & 0.27 & 0.25 & 1.2 & 0.00 & 0.27 \\ 4080 & -57 . & 70 . & 0.24 & 0.29 & 1.2 & 0.17 & 0.23 \\ 4082 & -58 . & 68 . & 0.23 & 0.26 & 1.4 & 0.10 & 0.23 \\ 4084 & -57 . & 66 . & 0.23 & 0.25 & 1.6 & 0.07 & 0.23 \\ 4086 & -54 . & 71 . & 0.23 & 0.25 & 1.8 & 0.07 & 0.23 \\ 4089 & -46 . & 72 . & 0.20 & 0.27 & 1.9 & 0.23 & 0.19 \\ 4090 & -55 . & 57 . & 0.26 & 0.26 & 1.7 & 0.00 & 0.26 \\ 4092 & -57 . & 55 . & 0.26 & 0.27 & 1.4 & 0.03 & 0.26 \\ 4094 & -57 . & 62 . & 0.26 & 0.27 & 1.4 & 0.03 & 0.26 \\ 4096 & -52 . & 85 . & 0.23 & 0.25 & 2.0 & 0.07 & 0.23\end{array}$

PHITD VSHGR RHSP PFMSP RWAX PPMAX RWAD PPHD SH RMF

$\begin{array}{llllllllll}0.24 & 0.100 & 0.05 & 37004 & 0.02 & 99025 & 0.04 & 54920, & 1.0999 .0099 .00\end{array}$

$\begin{array}{lllllllllll}0.25 & 0.400 & 0.05 & 39187 . & 0.03 & 57727 & 0.06 & 30751 . & 0.81 & 0.15 & 1.10\end{array}$

$\begin{array}{llllllllllll}0.24 & 0.633 & 0.05 & 39486 . & 0.03 & 64649 & 0.05 & 34612 . & 0.56 & 0.17 & 1.06\end{array}$

$\begin{array}{llllllllllll}0.24 & 0.133 & 0.05 & 40073 . & 0.03 & 54950 . & 0.05 & 36250 . & 0.91 & 0.13 & 1.23\end{array}$

$\begin{array}{llllllllllll}0.27 & 0.233 & 0.05 & 40222 . & 0.03 & 54826 . & 0.06 & 29546 . & 0.87 & 0.13 & 1.32\end{array}$

$\begin{array}{llllllllllll}0.26 & 0.500 & 0.05 & 39936 . & 0.03 & 64979 . & 0.05 & 36507 . & 0.91 & 0.17 & 1.15\end{array}$

$\begin{array}{llllllllllll}0.24 & 0.433 & 0.05 & 40222 . & 0.03 & 55457 . & 0.05 & 34737 . & 0.90 & 0.13 & 1.32\end{array}$

$\begin{array}{lllllllllll}0.24 & 0.367 & 0.05 & 39936 . & 0.05 & 40542 . & 0.06 & 31501 . & 0.88 & 0.09 & 1.45\end{array}$

$\begin{array}{llllllllllll}0.24 & 0.533 & 0.05 & 33925 . & 0.05 & 34614 & 0.06 & 28210 & 0.85 & 0.07 & 1.38\end{array}$

$\begin{array}{lllllllllll}0.22 & 0.567 & 0.05 & 36448, & 0.03 & 77506 . & 0.06 & 32426 . & 0.8599 .00 & 99.00\end{array}$

$\begin{array}{lllllllllll}0.26 & 0.067 & 0.05 & 39220 & 0.03 & 65250 . & 0.08 & 22525, & 0.78 & 0.17 & 1.04\end{array}$

$\begin{array}{lllllllllllll}0.26 & 0.000 & 0.05 & 39800 . & 0.03 & 72761 . & 0.06 & 27809 & 0.84 & 0.20 & 1.04\end{array}$

$\begin{array}{llllllllllll}0.26 & 0.233 & 0.05 & 39665 . & 0.04 & 50957 . & 0.06 & 27190 . & 0.84 & 0.12 & 1.31\end{array}$

$\begin{array}{lllllllllllll}0.24 & 1.000 & 0.05 & 38199 . & 0.05 & 36599 . & 0.07 & 24190 . & 0.80 & 0.08 & 1.27\end{array}$ 
WELL NMMBER $=29$

FIELD : CERRO PRIETO

KANGE : FROM 4070 TO 4096

$$
\begin{array}{ll}
\text { Tmf }= & 75.000 \\
\text { FHOmf }= & 1.100 \\
\text { FHIDC }= & 0.05 \\
\text { FHINC }= & 0.35 \\
\text { AN }= & 1.00 \\
\text { AM }=2.30 \\
\text { RWCLY }=0.10 \\
\text { TDEEP }=400.0 \\
\text { RSH }=1.60
\end{array}
$$

\begin{tabular}{|c|c|c|c|}
\hline DEPTH & SP & PHId PHIn & VSH FHIE \\
\hline 4070 & -47. & $\begin{array}{lll}58 . & 0.22 & 0.29\end{array}$ & $\begin{array}{llll}1.0 & 0.23 & 0.21\end{array}$ \\
\hline 4072 & 54. & 67. 0.220 .30 & $\begin{array}{llll}1.6 & 0.27 & 0.21\end{array}$ \\
\hline 4074 & -55. & 74. $0.22 \quad 0.29$ & $\begin{array}{lll}1.5 & 0.23 & 0.21\end{array}$ \\
\hline 4076 & -57. & $\begin{array}{llll}59 . & 0.23 & 0.27\end{array}$ & 1.40 .130 .22 \\
\hline 4078 & -58. & 62. 0.270 .25 & 1.20 .000 .27 \\
\hline 4080 & -57. & $70.0 .24 \quad 0.29$ & 1.20 .170 .23 \\
\hline 4082 & -58. & 69. 0.230 .26 & 1.40 .100 .23 \\
\hline 4084 & -57. & 66.0 .230 .25 & $1.60 .07 \quad 0.23$ \\
\hline 4086 & -54. & 71.0 .230 .25 & 1.80 .070 .23 \\
\hline 4083 & -46. & 72. $0.20 \quad 0.27$ & 1.90 .230 .19 \\
\hline 4090 & -55. & 57. 0.260 .26 & $1.70 .00 \quad 0.26$ \\
\hline 4092 & -57. & 0.260 .27 & $1.40 .03 \quad 0.26$ \\
\hline 4094 & -57 & 62. $0.26 \quad 0.27$ & $1.40 .03 \quad 0.26$ \\
\hline & & 35. 0.230 .25 & \\
\hline
\end{tabular}

COMFUTED DATA IS AS BEIOHE

FHITD USHGR RWSP FPMSP RHAX PPMAX RWAD PPMD SW RMF

$\begin{array}{lllllllllll}0.24 & 0.100 & 0.05 & 26716 . & 0.01 & 99025 . & 0.03 & 37395 . & 1.0699 .0099 .00\end{array}$ $\begin{array}{lllllllllll}0.25 & 0.400 & 0.05 & 27865 . & 0.02 & 57727 . & 0.06 & 21152 . & 0.79 & 0.17 & 0.77\end{array}$ $\begin{array}{lllllllllll}0.24 & 0.633 & 0.04 & 23023 . & 0.02 & 64649 . & 0.05 & 23721 . & 0.85 & 0.22 & 0.70\end{array}$ $\begin{array}{llllllllllll}0.24 & 0.133 & 0.04 & 28332 . & 0.02 & 54950 \text {. } & 0.05 & 24691 . & 0.89 & 0.15 & 0.92\end{array}$ $\begin{array}{lllllllllll}0.27 & 0.233 & 0.04 & 28484 & 0.02 & 54826 . & 0.06 & 20115 . & 0.86 & 0.15 & 0.95\end{array}$ $\begin{array}{lllllllllll}0.26 & 0.500 & 0.04 & 28332 & 0.02 & 64979 . & 0.05 & 24990 & 0.89 & 0.20 & 0.77\end{array}$ $\begin{array}{lllllllllll}0.24 & 0.433 & 0.04 & 28484 & 0.02 & 55457 . & 0.05 & 23724 . & 0.89 & 0.15 & 0.95\end{array}$ $\begin{array}{llllllllllll}0.24 & 0.367 & 0.04 & 28332 & 0.03 & 40542 . & 0.06 & 21504 & 0.86 & 0.09 & 1.10\end{array}$ $\begin{array}{lllllllllll}0.24 & 0.533 & 0.05 & 27865 . & 0.04 & 34614 & 0.06 & 19356 . & 0.83 & 0.08 & 1.08\end{array}$ $\begin{array}{lllllllllllll}0.22 & 0.567 & 0.05 & 26545 . & 0.02 & 77506 . & 0.05 & 22440 . & 0.8399 .0099 .00\end{array}$ $\begin{array}{llllllllllll}0.26 & 0.067 & 0.04 & 28023 & 0.02 & 65250 & 0.08 & 15441 . & 0.76 & 0.22 & 0.69\end{array}$ $\begin{array}{llllllllllll}0.26 & 0.000 & 0.04 & 28332 . & 0.02 & 72761 . & 0.06 & 19047 . & 0.83 & 0.27 & 0.63\end{array}$ $\begin{array}{llllllllllll}0.26 & 0.233 & 0.04 & 28332 & 0.03 & 50957 . & 0.06 & 18699 & 0.82 & 0.13 & 0.97\end{array}$ $\begin{array}{llllllllllllllllllllllll}0.24 & 1.000 & 0.05 & 27546 . & 0.04 & 36599 & 0.07 & 16692 & 0.78 & 0.09 & 0.99\end{array}$ 


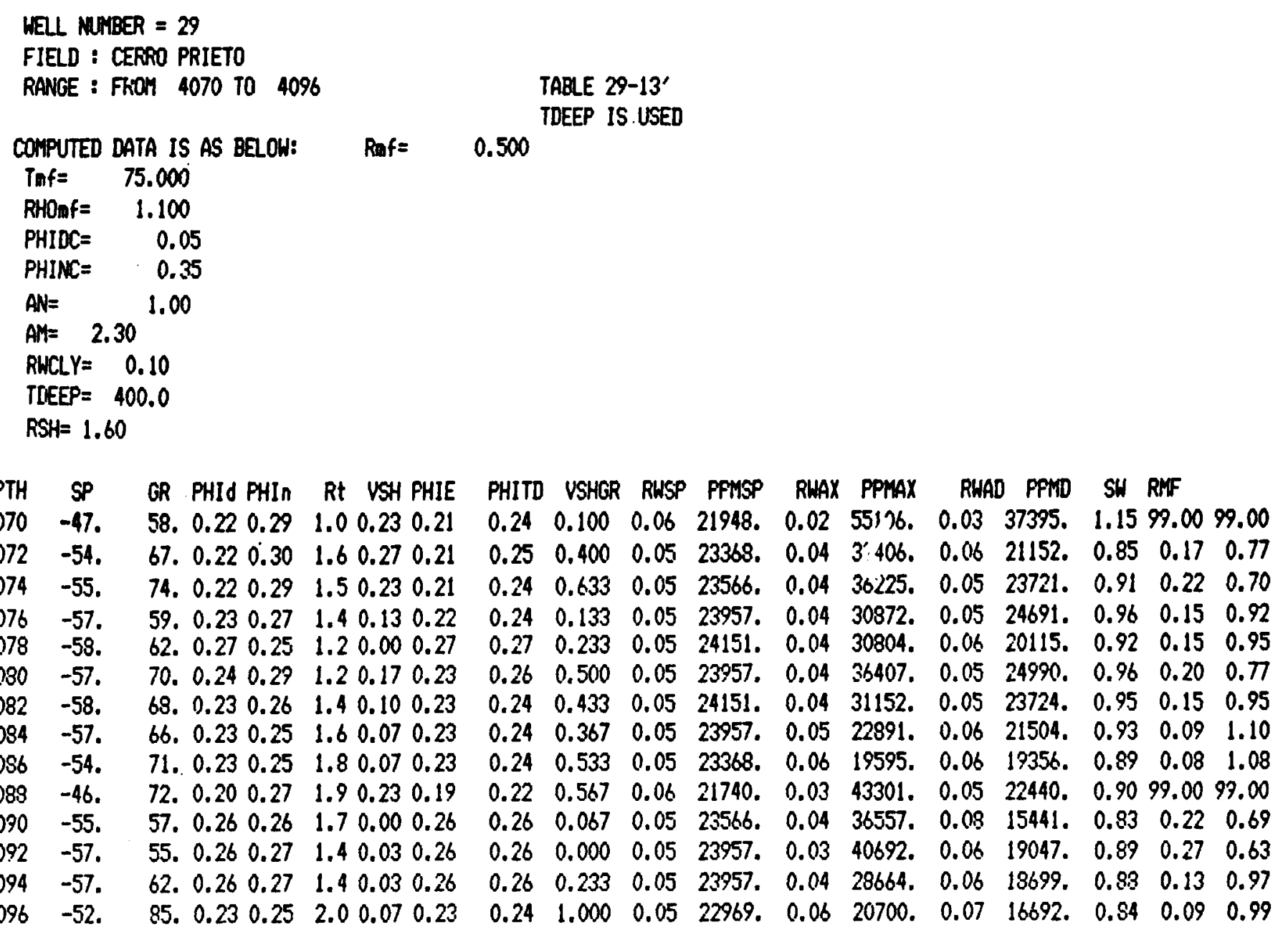


LOCATION:

The calculation of the coordinates uses as origin the coordinates for the center of Unit No. 1 of the Cerro Prieto Geothermal Power Plant; coordinates are referred to the rehabilitation system of the Irrigation District of the Department of Hydraulic Resources.

$$
\begin{aligned}
& X=-17176.02 \mathrm{~m}\left(56351.1^{\prime}\right) \\
& Y=-1156.14 \mathrm{~m}\left(3793.1^{\prime}\right)
\end{aligned}
$$

Rotary table elevation $3.35 \mathrm{~m}\left(11.0^{\prime}\right)$ above ground level

Ground elevation (missing)

The well is located approximately $342.0 \mathrm{~m}$ (1122.0') northeast of well $M-11$ and $342.0 \mathrm{~m}\left(1122.0^{\prime}\right)$ northwest of well M-38.

DRILLING $50.8 \mathrm{~cm}\left(20^{\prime \prime} \emptyset\right)$ HOLE

Started drilling at 11:00 h on July 15, 1973, drilling with $37.5 \mathrm{~cm}$ (14-3/4"Ø) bit, four $16.5 \mathrm{~cm}\left(6-1 / 2^{\prime \prime} \emptyset\right) \mathrm{drill}$ collars, and $11.4 \mathrm{~cm}\left(4-1 / 2^{\prime \prime} \emptyset\right)$ fh drill string, to a depth of $198.65 \mathrm{mbgl}$ (651.7').

Circulated at the bottom, pulled bit and drill string out to the surface.

Inserted $50.8 \mathrm{~cm}\left(20^{\prime \prime} \emptyset\right)$ hole opener with $38.1 \mathrm{~cm}$ (15"Ø) guide bit and drill string; opened the hole up to a depth of $181.65 \mathrm{mbgl}$ (596.0').

Conditioned mud and hole, pulled drill string out to the surface.

CEMENTING $40.6 \mathrm{~cm}$ (16"Ø) CASING

Prepared and ran in $40.6 \mathrm{~cm}\left(16^{\prime \prime} \emptyset\right)$, grade $H-40116.6 \mathrm{~kg} / \mathrm{m}(75 \mathrm{lb} / \mathrm{ft})$ and $96.7 \mathrm{~kg} / \mathrm{m}(65 \mathrm{lb} / \mathrm{ft})$ buttress thread casing to a depth of $176.98 \mathrm{mbg} 1\left(580.6^{\prime}\right)$. The casing was equipped with a float shoe, float collar, and 15 centralizers.

With equipment and personnel from the Byron Jackson Company, cemented the $40.6 \mathrm{~cm} \cdot\left(16^{\prime \prime} \emptyset\right)$ casing with $34.6 \mathrm{~m}^{3}\left(1221.9 \mathrm{ft}^{3}\right)$ of cement grout modified with Diamix $[36700 \mathrm{~kg}(80908.8 \mathrm{lb})]$, by displacement. The excess cement came out to the surface.

After the cement had set, removed cementing head and surface connections.

With equipment and personnel from the Perfesa Company, cut $40.6 \mathrm{~cm}$ (16"ø) casing $1.67 \mathrm{~m}\left(5.48^{\prime}\right)$ above the floor of the cellar and welded $40.6 \mathrm{~cm}$ (16' $\emptyset$ ) we11-head. Installed $40.6 \mathrm{~cm}\left(16^{\prime \prime} \emptyset\right) \mathrm{S}-900$ Shaffer blowout preventer and surface connections. 


\section{HYDRAULIC TEST}

Ran in $38.1 \mathrm{~cm}\left(15^{\prime \prime} \emptyset\right)$ bit, eight $16.5 \mathrm{~cm}\left(6-1 / 2^{\prime \prime} \emptyset\right)$ drill collars, and $11.4 \mathrm{~cm}\left(4-1 / 2^{\prime \prime} \emptyset\right)$ fh drill string to a depth of $165.47 \mathrm{mbgl}$ (542.9'), where the top of the cement was reached.

Closed blowout preventer, satisfactorily tested casing cementing job and surface connections with a pressure of $42 \mathrm{~kg} / \mathrm{cm}^{2}(600 \mathrm{psig})$ for $30 \mathrm{~min}$.

\section{DRILLING $38.1 \mathrm{~cm}\left(15^{\prime \prime} \emptyset\right)$ HOLE}

With $38.1 \mathrm{~cm}\left(15^{\prime \prime} \emptyset\right)$ bit and drill string, drilled through collar, cement, and casing shoe; continued drilling in plastic sandy clay to $496.65 \mathrm{mbgl}$ (1629.4'), where inclination $\log$ was taken with Kuster instrument, obtaining a reading of $0^{\circ} 10^{\prime}$.

Continued drilling to $732.95 \mathrm{mbgl}$ (2404.7'). Increased the number of drill collars to a total of 10 ; continued drilling in plastic clay and shale to 796.65 $\operatorname{mbg} 1\left(2613.6^{\prime}\right)$.

Conditioned mud and hole, pulled drill string out to the surface.

\section{ELECTRICAL LOGS}

With equipment and personnel from the Schlumberger Company, obtained induction $\log$ from 181.1 to $800.6 \mathrm{mbrt}$ ( $594^{\prime}$ to $2626^{\prime}$ ) and microlog from 181.1 to 800.0 mbrt (594' to $\left.2624^{\prime}\right)$.

\section{CEMENTING $29.9 \mathrm{~cm}\left(11-3 / 4^{\prime \prime} \emptyset\right)$ CASING}

Prepared and ran in $29.9 \mathrm{~cm}\left(11-3 / 4^{\prime \prime} \emptyset\right)$ grade $\mathrm{N}-80$ and $\mathrm{K}-5589.3 \mathrm{~kg} / \mathrm{m}$ (60 $\mathrm{lb} / \mathrm{ft}$ ) buttress thread casing to $792.65 \mathrm{mbgl}\left(2600.5^{\prime}\right)$. It was equipped with a float shoe, 1 float collar, and 42 centralizers.

With equipment and personnel from the Byron Jackson Company, cemented the $29.9 \mathrm{~cm}\left(11-3 / 4^{\prime \prime} \emptyset\right)$ casing with $49000 \mathrm{~kg}$ (108 $\left.025.4 \mathrm{lb}\right)$ modified with Diamix in the ratios $1^{\prime \prime} 1$ and $1 " 2,37.4$ and $14.3 \mathrm{~m}^{3}$ (1320.7 and $505.0 \mathrm{ft}^{3}$ ) of grout. The cement came out to the surface.

After the cement had set, released pressure, removed cementing head, blowout preventer, and surface connections. 
With equipment and personnel from Timex, cut $40.6 \mathrm{~cm}(16 " \emptyset)$ and $29.9 \mathrm{~cm}$ (11-3/4'Ø) casings 1.20 and $1.58 \mathrm{~m}\left(3.94^{\prime}\right.$ and $\left.5.18^{\prime}\right)$, respectively, above the floor of the cellar.

Welded $30.5 \times 29.9 \mathrm{~cm}\left(12^{\prime \prime} \times 11-3 / 4^{\prime \prime} \emptyset\right) \mathrm{S}-900$ well-head to the $29.9 \mathrm{~cm}$ (11-3/4" $\emptyset)$ casing with inside and outside beads.

Installed $30.5 \times 40.6 \mathrm{~cm}\left(12^{\prime \prime} \times 16^{\prime \prime} \emptyset\right)$ adapter spool, blowout preventer, and surface connections.

\section{HYDRAULIC TEST}

Ran in $27.0 \mathrm{~cm}\left(10-5 / 8^{\prime \prime} \emptyset\right)$ bit, ten $16.5 \mathrm{~cm}\left(6-1 / 2^{\prime \prime} \emptyset\right)$ drill collars, and $11.4 \mathrm{~cm}\left(4-1 / 2^{\prime \prime} \emptyset\right)$ fh drill string to a depth of $741.65 \mathrm{mbgl}$ (2433.2') where the top of the cement was reached.

Closed blowout preventer, satisfactorily tested $29.9 \mathrm{~cm}\left(11-3 / 4^{\prime \prime} \emptyset\right)$ casing, cementing job, and surface connections with a pressure of $70.4 \mathrm{~kg} / \mathrm{cm}^{2}(1000$ psig) for $30 \mathrm{~min}$.

DRILLING $27.0 \mathrm{~cm}\left(10-5 / 8^{\prime \prime} \emptyset\right)$ HOLE

With $27.0 \mathrm{~cm}(10-5 / 8 " \emptyset)$ bit and drill string drilled through cement plug, collar, and casing shoe; continued drilling in plastic sandy clay to 696.0 mbgl (2283.4'). Continued drilling in clay, shale, and sandstone to 1016.65 mbgl (3335.4'). Partial losses of mud occurred at this depth, and the mud was therefore prepared with sealing material. Drilled with partial losses to $1326.65 \mathrm{mbgl}$ (4352.5'), where the losses were minimized.

Removed sealing material, conditioned mud and hole, pulled drill string out to the surface.

The chemical material used in drilling the section 1016.65 to $1326.65 \mathrm{mbgl}$ (3335.4' to $4352.5^{\prime}$ ) to control the loss was as follows:

$$
\begin{aligned}
& \frac{\text { Depth (mbgl) }}{1016.65 \text { to } 1326.65} \\
& \left(3335.4^{\prime} \text { to } 4352.5^{\prime}\right)
\end{aligned}
$$

\begin{tabular}{lrl} 
Chemical & Material Used \\
\hline Milgel & 387 sacks \\
Milflo & 43 & $" \prime$ \\
Unical & 37 & $" \prime$ \\
Milcon & 3 & $" 1$ \\
Soda C. & 29 & $"$ \\
Cello Flake & 13 & \\
Nut & & \\
Mil Flake & $10 "$ \\
Waste & $30 \mathrm{~kg}(66.1 \mathrm{lb})$ \\
Diesel & 9400 liters $(2483.3 \mathrm{gal})$
\end{tabular}


THERMAL LOGS

With equipment and personnel from the Federal Electricity Commission, obtained temperature $10 \mathrm{~g}$ from 196.65 to $1321.65 \mathrm{mbgl}$ ( 645.2 ' to 4336.1 '); maximum bottom temperature $173^{\circ} \mathrm{C}\left(343.4^{\circ} \mathrm{F}\right)$.

Ran in bit and drill string to the bottom of the well; added 70 blocks of ice [875 kg (1929.0 1b)] to the mud in the pits, refrigerated the mud column in the well and pulled drill string out to the surface.

\section{ELECTRICAL LOG}

With equipment and personnel from the Schlumberger Company, obtained dual-induction laterolog from 793.9 to $1326.8 \mathrm{mbrt}$ ( 2604 ' to $4352^{\prime}$ ), density $\log$ from 793.9 to 1328.7 mbrt (2604' to $4358^{\prime}$ '), and neutron $\log$ from 793.9 to $1328.7 \mathrm{mbrt}\left(2604^{\prime}\right.$ to $4358^{\prime}$ ).

\section{CEMENTING $19.4 \mathrm{~cm}\left(7-5 / 8^{\prime \prime} \emptyset\right)$ CASING}

Prepared and ran in $19.4 \mathrm{~cm}\left(7-5 / 8^{\prime \prime} \emptyset\right)$ grade $\mathrm{J}-55,39.3 \mathrm{~kg} / \mathrm{m}(26.4 \mathrm{lb} / \mathrm{ft})$ buttress thread, smooth and slotted casing to $1310.71 \mathrm{mbg} 1$ (4300.2'), equipped with $J$ collar, float collar, cementing collar, blank collar, blank casing shoe, 4 canvas metal petal baskets, and the centralizers necessary for good cementing.

With equipment and personnel from the Byron Jackson Company, cemented the $19.4 \mathrm{~cm}$ (7-5/8"Ø) casing in two stages. In the first stage cemented with $3.440 \mathrm{~m}^{3}\left(121.5 \mathrm{ft}^{3}\right)$ of cement grout, type $\mathrm{G}$ modified with Diamix; opened J collar, checked circulation, and carried out the second stage of cementing with $32.150 \mathrm{~m}^{3}\left(1135.3 \mathrm{ft}^{3}\right.$ ) of cement, type $\mathrm{G}$, modified with Diamix.

While the cement was setting, released pressure on various occasions; after the cement had set, removed cementing head, blowout preventer, and surface connections.

Cut $19.4 \mathrm{~cm}\left(7-5 / 8^{\prime \prime} \emptyset\right)$ casing $0.20 \mathrm{~m}\left(0.66^{\prime}\right)$ above the $29.9 \mathrm{~cm}\left(11-3 / 4^{\prime \prime} \emptyset\right)$ well-head, installed blowout preventer and surface connections.

\section{HYDRAULIC TEST}

Ran in $16.5 \mathrm{~cm}\left(6-1 / 2^{\prime \prime} \emptyset\right)$ bit and drill string to $867.85 \mathrm{mbgl}$ (2847.2') where the top of the cement was reached. 
Closed blowout preventer, satisfactorily tested the casing, cementing job, and surface connections with a pressure of $63.4 \mathrm{~kg} / \mathrm{cm}^{2}$ (900 psig) for $30 \mathrm{~min}$.

Drilled through $\mathrm{J}$ cement collar at $878.39 \mathrm{mbgl}$ (2881.8'), through float collar at $957.67 \mathrm{mbg} 1$ (3141.9'), cementing collar at $971.55 \mathrm{mbg} 1$ (3187.5'), and reached blank collar at $985.73 \mathrm{mbgl}\left(3234.0^{\prime}\right)$.

Closed blowout preventer, satisfactorily tested the second stage of cementing and casing with a pressure of $63.4 \mathrm{~kg} / \mathrm{cm}^{2}(900 \mathrm{psig})$ for $30 \mathrm{~min}$.

Pulled bit and drill string out, disconnecting pipe by pipe at the surface, observing that the bit was incomplete, one roll remaining in the well.

Hardened $16.5 \mathrm{~cm}\left(6-1 / 2^{\prime \prime} \emptyset\right)$ bit with tungsten weld, ran it in with 11.4 cm (4-1/2' collar, running it freely to a depth of $1001.75 \mathrm{mbgl}$ (3286.5').

\section{COMPLETION}

Pulled bit and drill string out to the surface, disconnecting pipe by pipe; removed blowout preventer and surface connections.

Installed $30.5 \times 20.3 \mathrm{~cm}\left(12^{\prime \prime} \times 8^{\prime \prime}\right)$ expansion spool, $20.3 \mathrm{~cm}$ ( $8^{\prime \prime \emptyset)}$ master valve, and surface connections.

Ran in $16.5 \mathrm{~cm}\left(6-1 / 2^{\prime \prime} \emptyset\right)$ bit with $7.3 \mathrm{~cm}\left(2-7 / 8^{\prime \prime} \emptyset\right) \mathrm{drill}$ string, redrilled to a depth of $1310.65 \mathrm{mbgl}\left(4300.0^{\prime}\right)$, circulated at the bottom, displaced mud by water until it circulated completely clean at the surface.

Pulled bit and drill string out to the surface, disconnecting pipe by pipe, removed blowout preventer and surface connections.

Welded blank cover with $5.1 \mathrm{~cm}\left(2^{\prime \prime} \emptyset\right)$ outlet over the $20.3 \mathrm{~cm}$ ( $\left.8^{\prime \prime} \emptyset\right)$ valve. Closed $20.3 \mathrm{~cm}\left(8^{\prime \prime} \emptyset\right)$ master valve. Considered the construction of this well completed at 7:00 h on August 26, 1973 .

Compiled

(signed)

Raul Rivera Olguin
Reviewed

(signed)

Engineer Rene de Leon Botello SUPERINTENDENT OF WELL DRILLING

Approved

(signed) 
SP-GAMMA RAY OVERLAYS WELL 42 


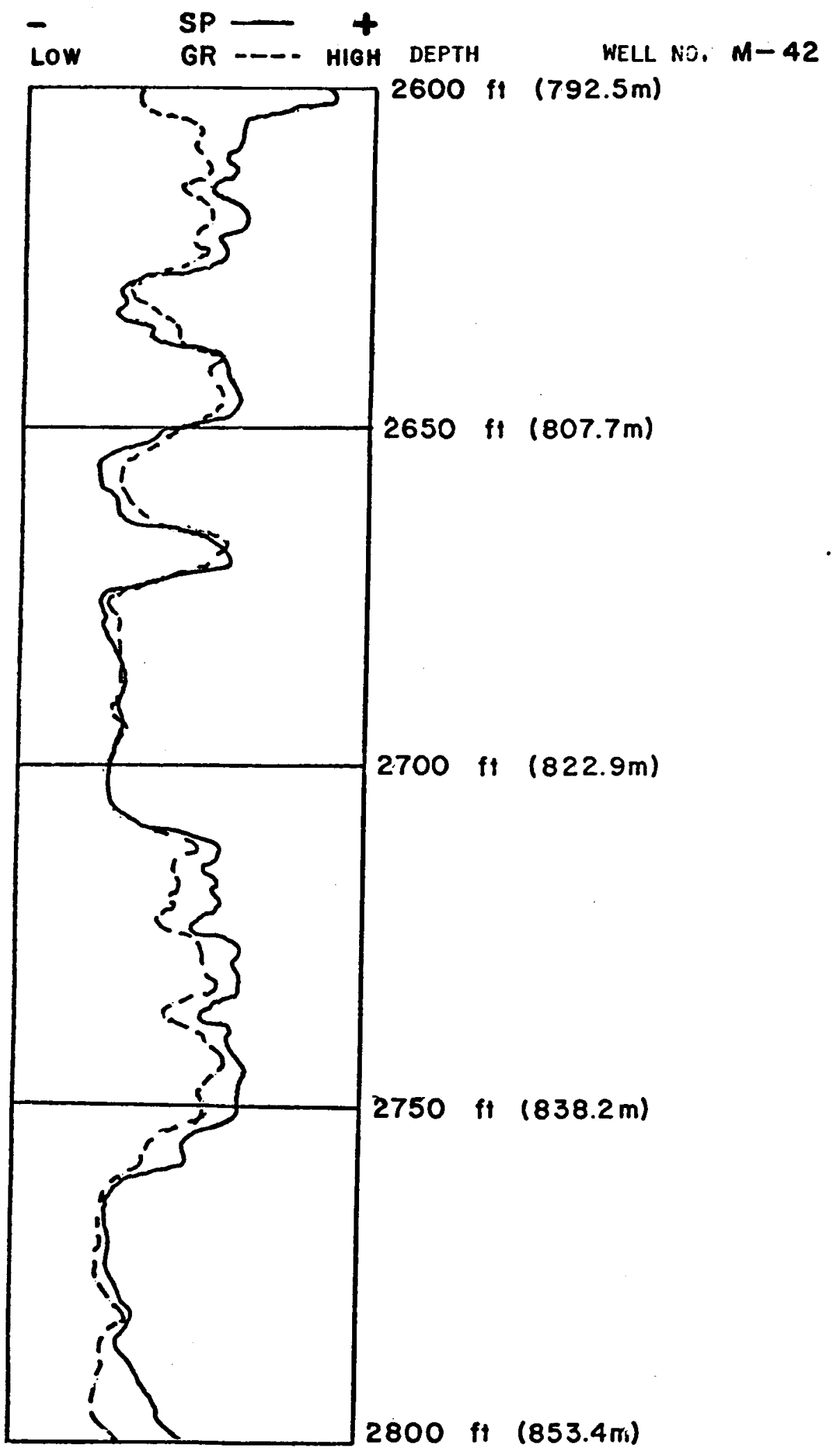

Fig. D-17. SP-Gamma Ray Overlay. 


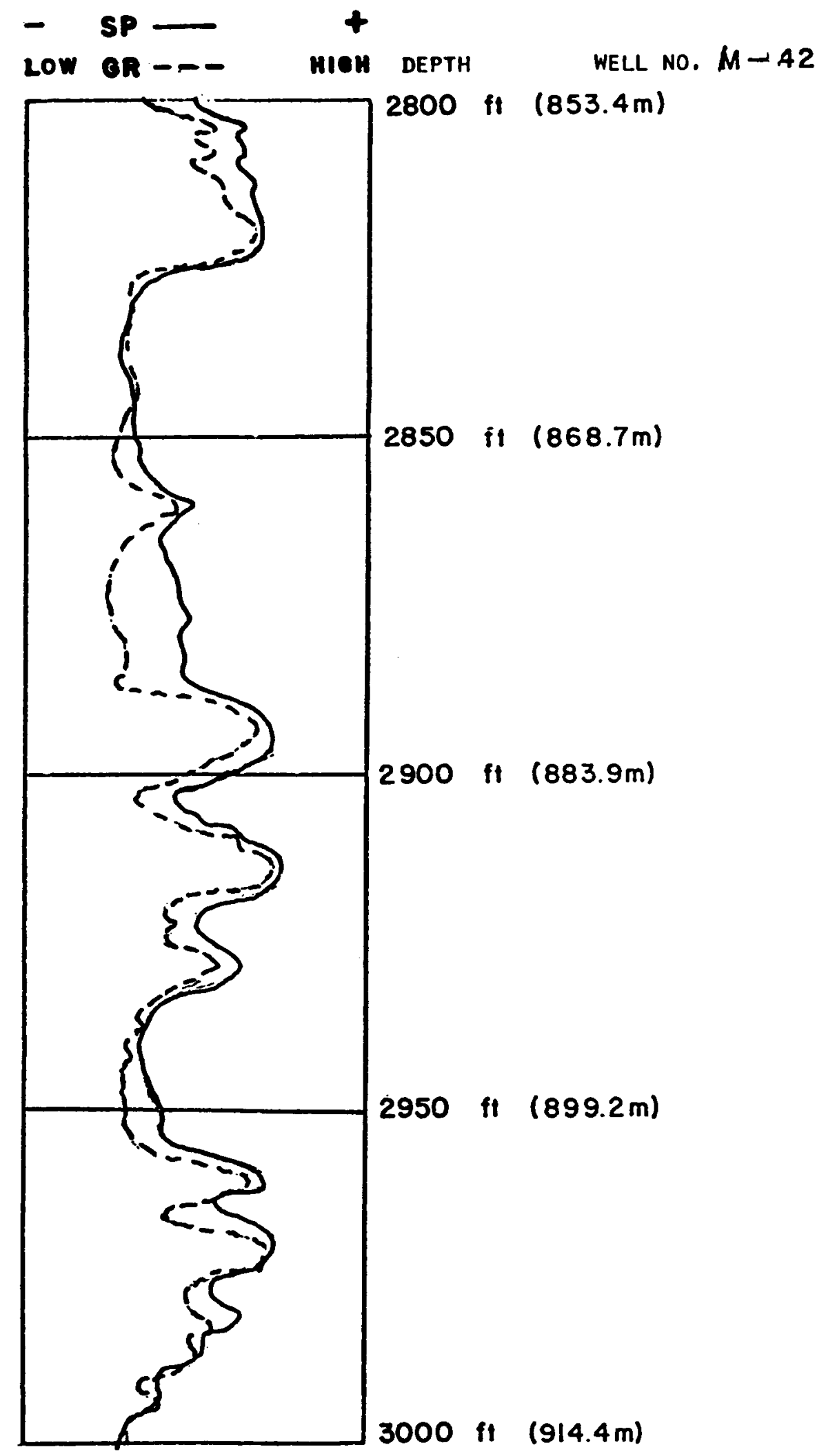

Fig. D-18. SP-Gamma Ray Overlay. 


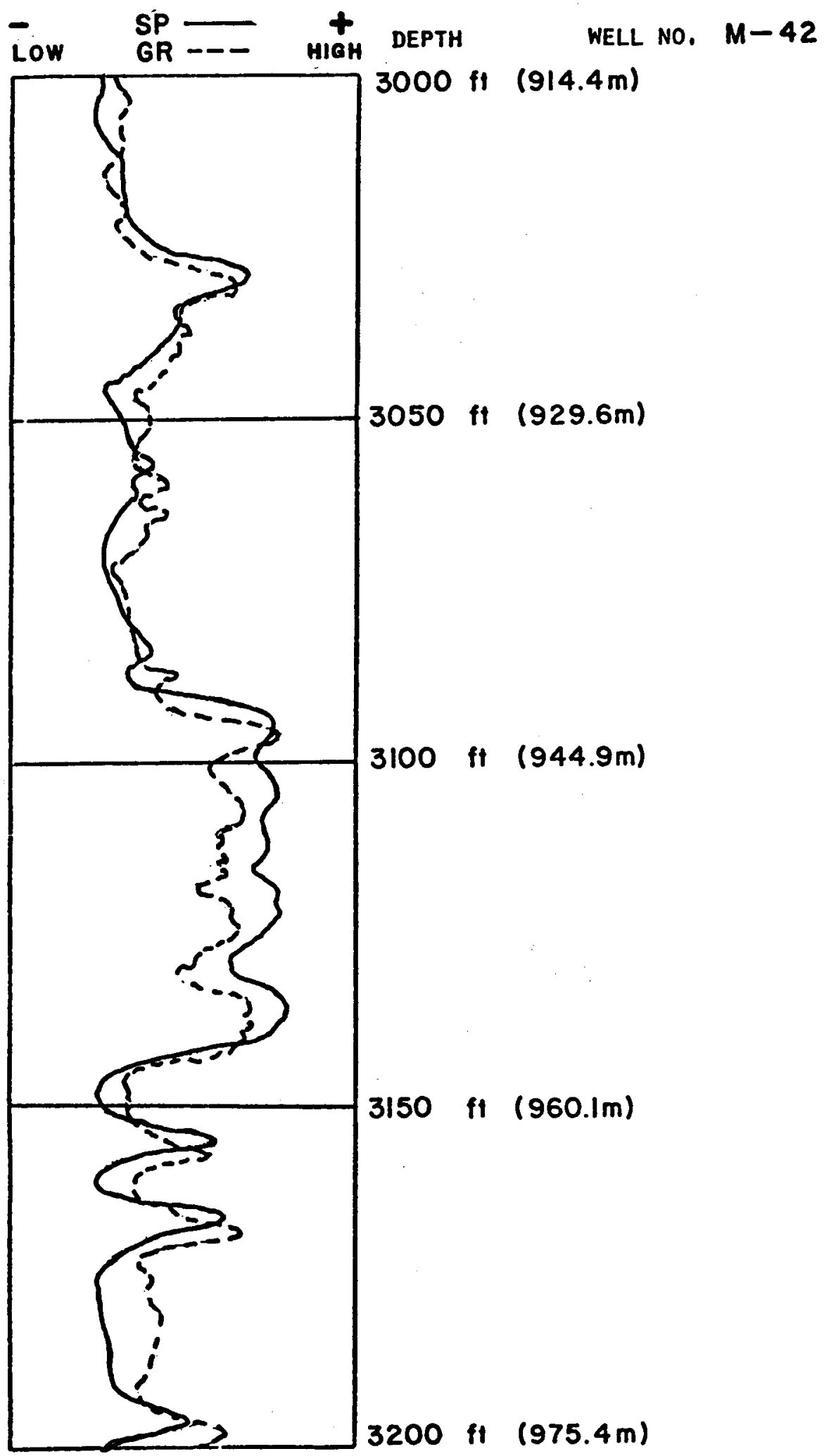

Fig. D-19. SP-Gammay Ray Overlay. 


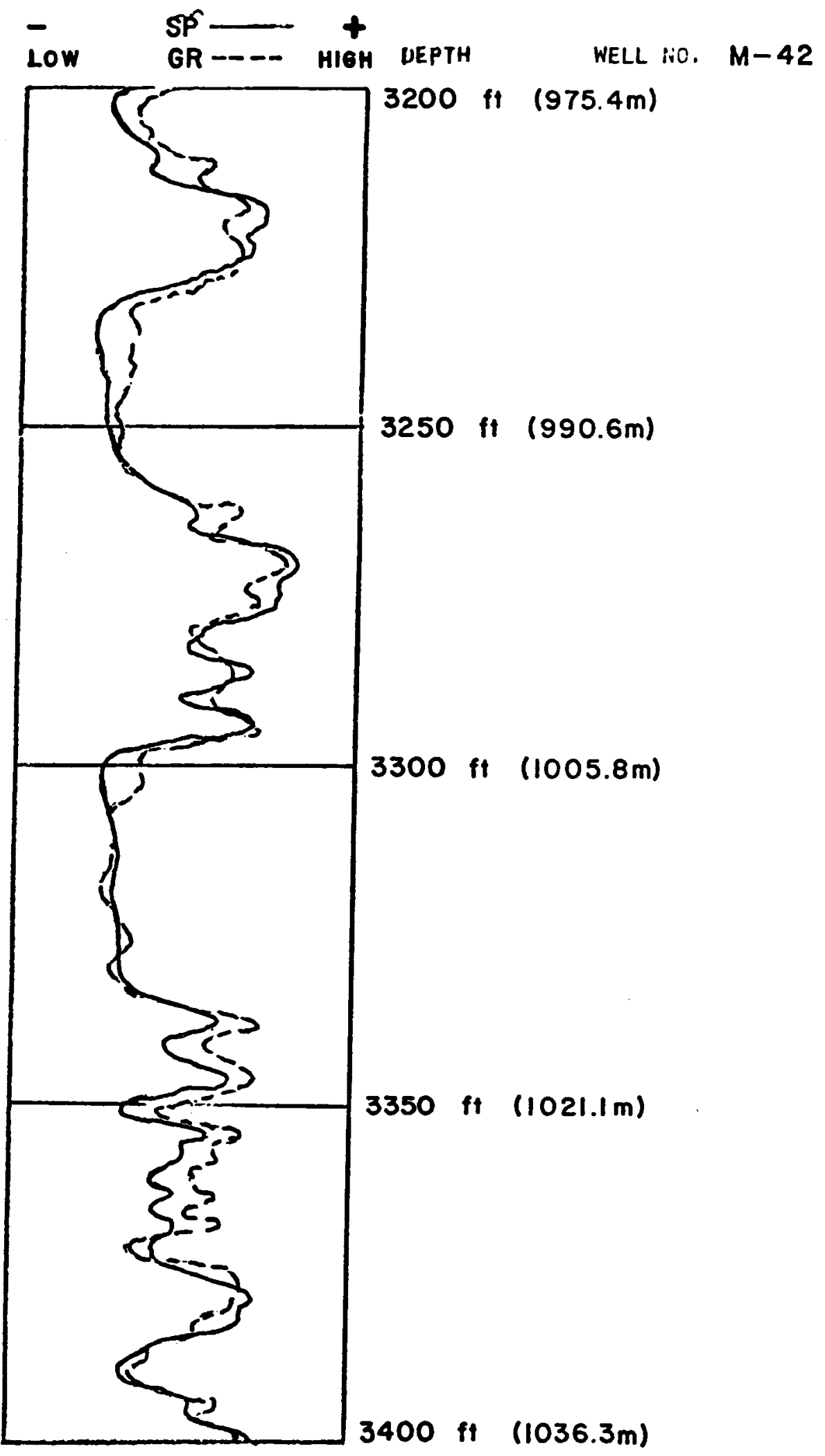

Fig. D-20. SP-Gamma Ray Overlay. 


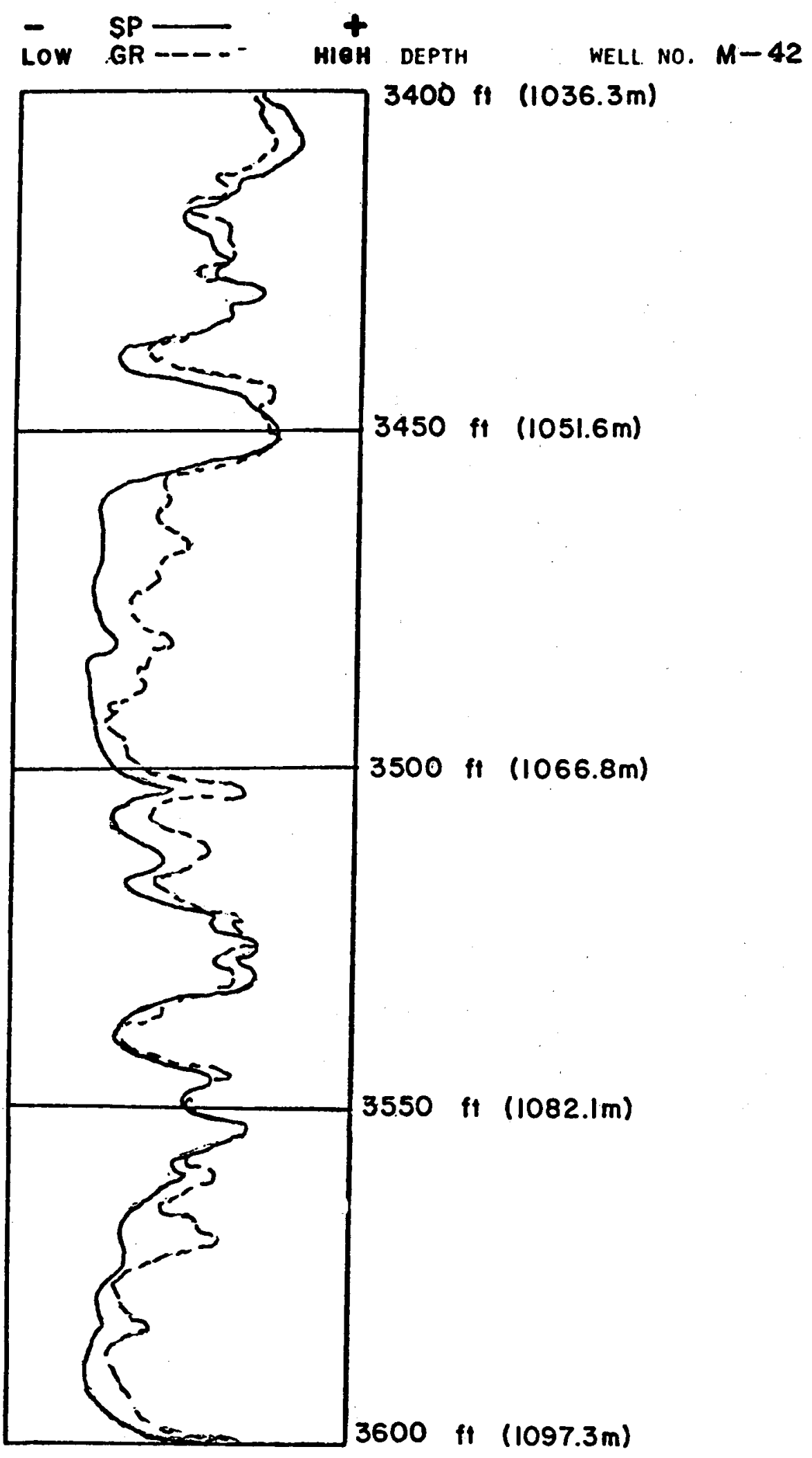

Fig. D-21. SP-Gamma Ray Overlay. 


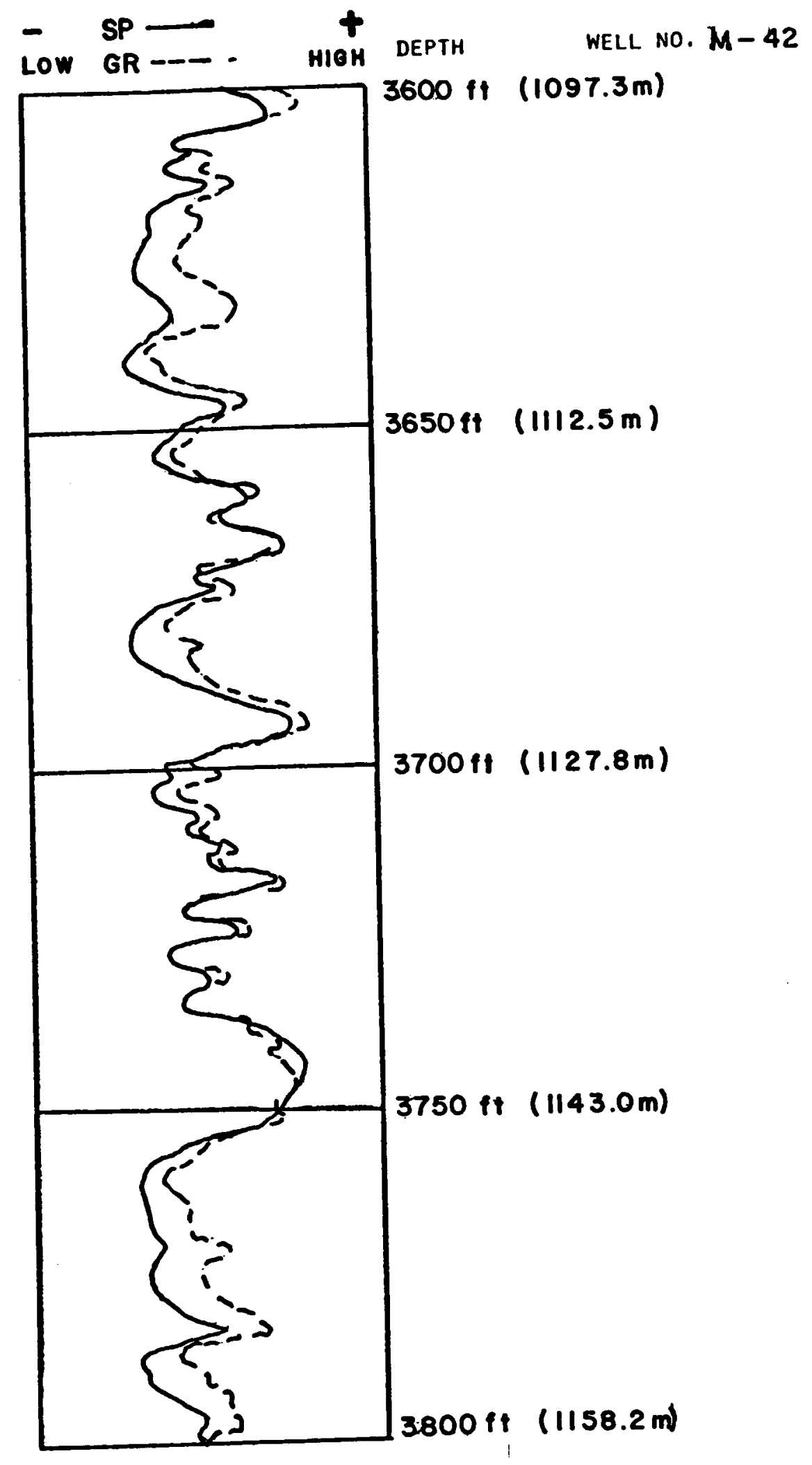

Fig. D-22. SP-Gamma Ray Overlay. 


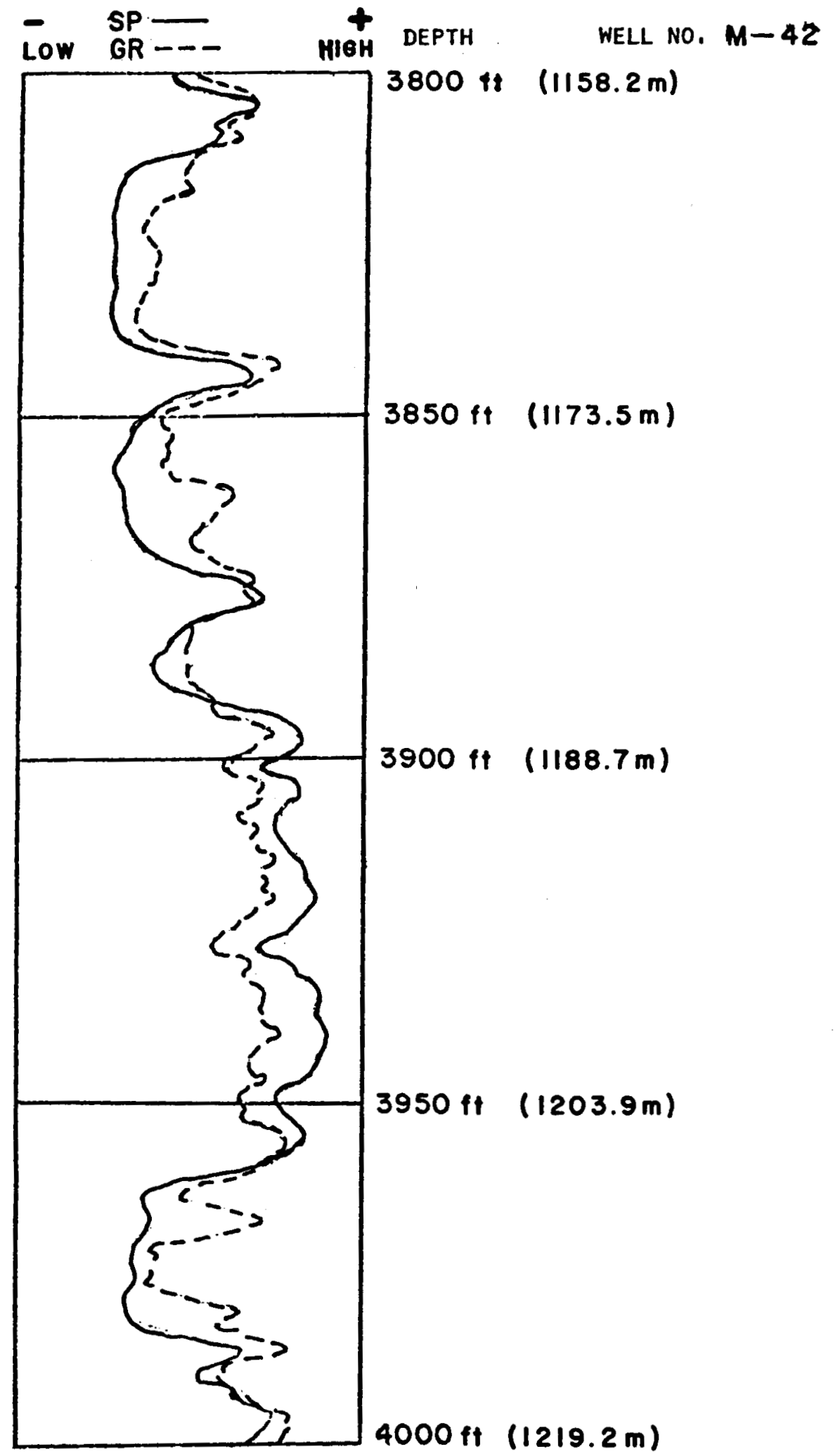

Fig. D-23. SP..Gamma Ray Overlay. 


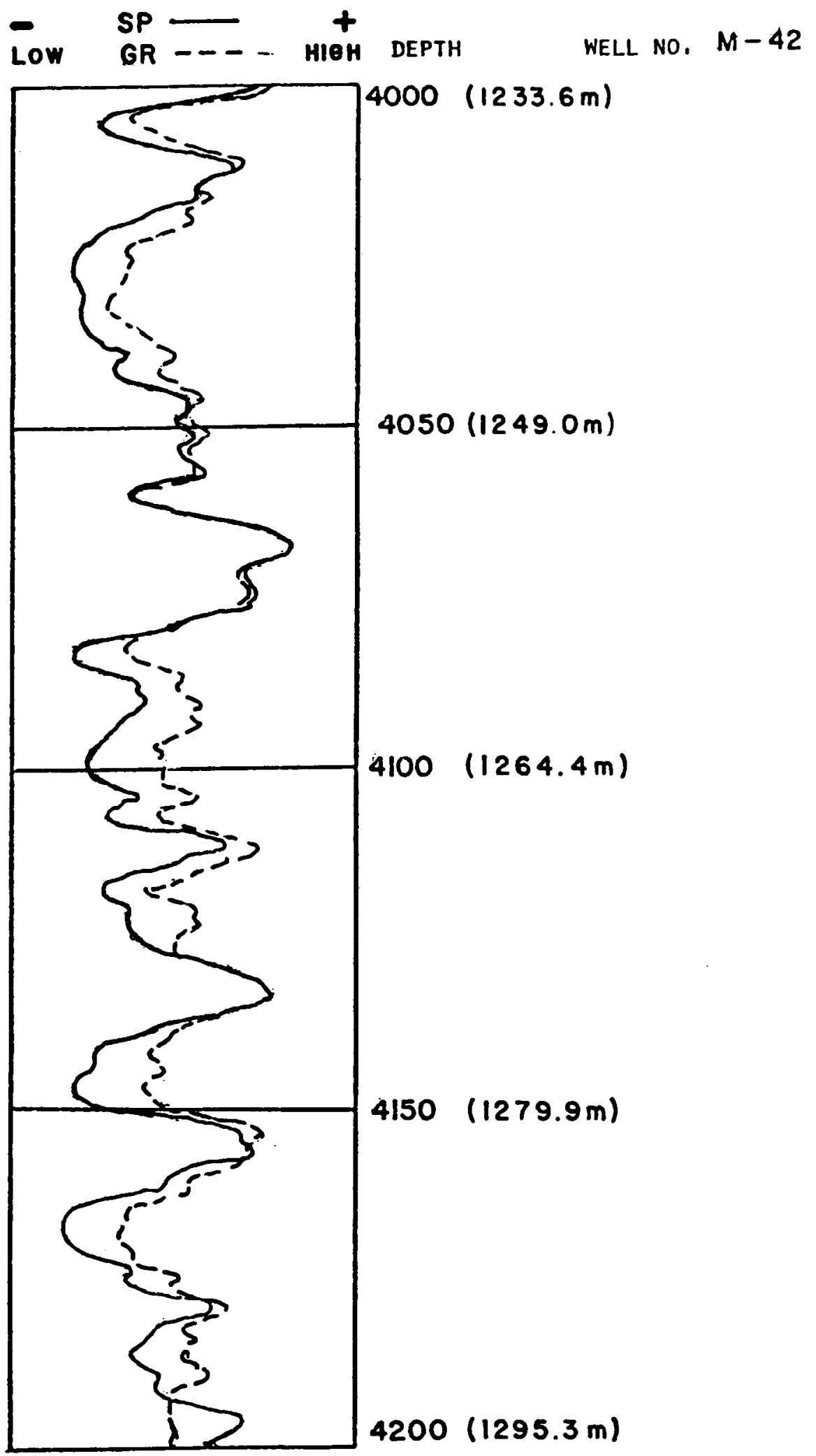

Fig. D-24. SP-Gamma Ray Overlay. 


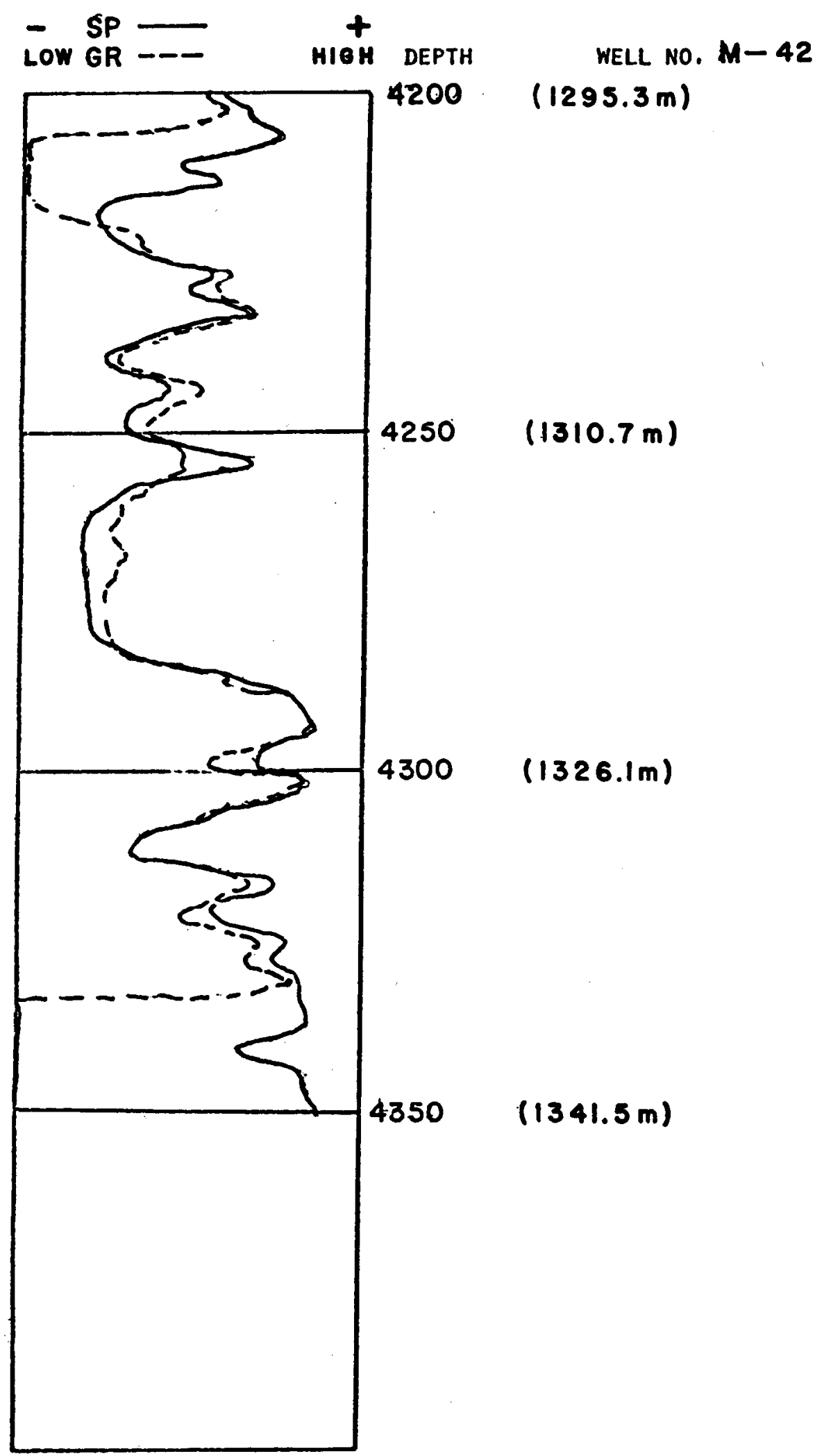

Fig. D-25. SP-Gamma Ray Overlay. 


\section{COMPUTED RESULTS NELL 42}

\section{WELL MUMBER $=42$}

FIELD : CERTO PRIETO

RANGE : FROM 2674 TO 2708

COMPUTED DATA IS AS BELON:

Tan $=\quad 75.000$

RHOnf $=1.100$

PHIOC $=\quad 0.07$

PHINC $=\quad 0.36$

$A N=\quad 1.00$

$A I I=2.30$

RWCLY $=0.10$

TDEEP $=165.0$

$\mathrm{RSH}=1.00$
Rinf $=\quad 0.300$

\author{
TABle 42-1"
}

\begin{tabular}{|c|c|c|c|c|c|c|c|c|c|c|c|c|c|c|c|}
\hline DEPTH & $\mathbf{S P}$ & GR & FHId PHIn & YSH PHIE & PHITO & VSHGR & RWSP & PFMSP & RWAX & PPIAX & RWAI & FFMD & SW & RMF & \\
\hline 2674 & -63. & 44. & 0.250 .33 & $0.90 .28 \quad 0.23$ & 0.28 & 0.471 & 0.05 & 70044. & 0.06 & 55108. & 0.04 & 79704. & 0.94 & 0.11 & 2.33 \\
\hline 2676 & 67. & 53. & & 30.100 .28 & 0.30 & 1.000 & 0.05 & 72617. & 0.08 & 33422. & 0.05 & 3326. & .94 & & \\
\hline 78 & 67. & & & & 0.30 & 0.353 & 0.05 & 72617. & 0.08 & 40348. & 0.04 & & .01 & 0.08 & 2.85 \\
\hline 2680 & -65 & 43. & 0.300 .35 & $\begin{array}{lll}0.7 & 0.17 & 0.29\end{array}$ & 0.32 & 0.412 & 0.05 & 71348. & 0.08 & 38827. & 0.05 & 67212. & 0.92 & 0.07 & 2.69 \\
\hline 26.62 & -64. & 43. & $0.34 \quad 0.35$ & $\begin{array}{llll}0.7 & 0.03 & 0.34\end{array}$ & 0.34 & 0.412 & 0.05 & 70700. & 0.08 & 37713. & 0.06 & 52817. & 0.87 & 0.07 & 2.61 \\
\hline 2634 & -62. & 41. & 0.340 .39 & $\begin{array}{llll}0.7 & 0.17 & 0.33\end{array}$ & 0.36 & 0.294 & 0.05 & 68987. & 0.09 & 34629. & 0.07 & 45322. & 0.79 & 0.07 & 2.47 \\
\hline 2686 & -61. & 40. & 0.320 .40 & $\begin{array}{lll}0.7 & 0.28 & 0.3\end{array}$ & 0.35 & 0.235 & 0.05 & 63320. & 0.08 & 36909. & 0.06 & 54206 . & 0.82 & 0.07 & 2.36 \\
\hline 2688 & -60. & 44. & 0.350 .39 & $\begin{array}{llll}0.7 & 0.10 & 0.34\end{array}$ & 0.36 & 0.471 & 0.05 & 67645. & 0.08 & 38988. & 0.07 & 44106. & 0.80 & 0.08 & 2.26 \\
\hline 2690 & -62 & 43. & 0.310 .32 & 0.90 .030 .31 & 0.31 & 0.412 & 0.05 & 68937. & 0.07 & 41484. & 0.06 & 54027. & 0.89 & 0.08 & 2.39 \\
\hline $26 \% 2$ & -61. & 40. & 0.280 .31 & $\begin{array}{llll}1.0 & 0.10 & 0.27\end{array}$ & 0.29 & 0.235 & 0.05 & 68320 & 0.08 & 41305. & 0.06 & 58547. & 0.90 & 0.08 & 2.31 \\
\hline 2694 & -62. & 44. & 0.280 .29 & 1.10 .030 .28 & 0.28 & 0.471 & 0.05 & & 0.07 & & 0.06 & & .89 & 09 & 2.35 \\
\hline 2696 & -62. & 45. & 0.230 .27 & 1.00 .140 .22 & 0.25 & 0.529 & 0.05 & 63600. & 0.06 & 55000 . & 0.04 & 88674. & 1.05 & 0.11 & 2.23 \\
\hline $26: 9$ & -63. & 44. & 0.250 .30 & $\begin{array}{lll}1.2 & 0.17 & 0.24\end{array}$ & 0.27 & 0.471 & 0.05 & 69253. & 0.07 & 44733. & 0.05 & 59167. & 0.87 & 0.03 & 2.43 \\
\hline 2700 & -64 & 39. & 0.220 .23 & $\begin{array}{lll}1.3 & 0.21 & 0.21\end{array}$ & 0.24 & 0.176 & 0.05 & 69897. & 0.05 & 60718. & 0.05 & & 0.89 & 0.12 & 2.34 \\
\hline 2702 & -64 . & 36. & $0.22 \quad 0.28$ & $\begin{array}{lll}1.2 & 0.21 & 0.21\end{array}$ & 0.24 & 0.000 & 0.05 & 69897. & 0.05 & 65603. & 0.04 & 82272. & 0.97 & 0.13 & 2.28 \\
\hline 2704 & -65 . & 39. & 0.250 .28 & $\begin{array}{lll}1.0 & 0.10 & 0.24\end{array}$ & 0.26 & 0.176 & 0.05 & 70532. & 0.06 & 48376. & 0.05 & 72489. & 0.97 & 0.09 & 2.56 \\
\hline 2706 & -64 . & 43. & $0.26 \quad 0.26$ & $\begin{array}{lll}1.2 & 0.00 & 0.26\end{array}$ & 0.26 & 0.412 & 0.05 & 69397. & 0.06 & 56574. & 0.05 & 59320. & 0.93 & 0.11 & 2.38 \\
\hline 703 & -60. & 44. & $0.23 \quad 0.25$ & $\begin{array}{llll}1.2 & 0.07 & 0.23\end{array}$ & 0.24 & 0.471 & 0.05 & 66901. & 0.04 & 95377. & 0.04 & 77755 . & 1.03 & 0.23 & 1.60 \\
\hline
\end{tabular}


WELL MMMBER $=42$

FIELD : CERRO PRIETO

RANGE : FROM 2674 TO 2708

COMFUTED DATA IS AS BELON:

Timf $=75.000$

RHCmf $=1.100$

PHIDC $=0.07$

FHINC $=\quad 0.36$

$A N=\quad 1.00$

$A M=2.30$

RWCLY $=0.10$

TDEEP $=400.0$

$\mathrm{RSH}=1.00$
TABLE 42-2'

$R_{m f}=$ 0.300
TLIEEP IS USED

\begin{tabular}{|c|c|c|c|c|c|c|c|c|c|c|c|c|c|c|c|}
\hline & & & HId PHIn & VSH PHIE & HITD & USHGR & RWSP & PPMSP & & PMAX & & PPMD & & RMF & \\
\hline 674 & -63. & & & & & 0.471 & 0.04 & & & & & & & & \\
\hline 2676 & & & & 0. & . & 1.000 & 0.04 & & 03 & & & & & & \\
\hline & & & & & & 353 & 0.04 & & & & & & & 09 & \\
\hline & & & & & & & 04 & & & & & & & & \\
\hline 0. & & & & & & & & & & & & & & & \\
\hline 8 & 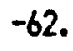 & & & & & 294 & & & & & & & & & \\
\hline 0 & & & & & & 235 & 0. & & & & & & & & 1.2 \\
\hline 85 & 6 & & & 0.70. & & 471 & 0.04 & & 0.03 & & & & & & 1.2 \\
\hline $6 \%$ & 52 & & se & 0.90 .030$. & & .412 & 0.04 & & 0.03 & & & & & .09 & 1.2 \\
\hline & 6 & & & 1.00 .1 & & .235 & 0.04 & & 0.03 & & & 1. & 86 & .09 & 1.2 \\
\hline & & & & 1.10 & & .471 & 0.04 & & 0.03 & & 06 & 33. & .84 & & 1.2 \\
\hline & s. & & 2 & 1.00. & & 0.529 & 0.04 & & 0.02 & 00. & & 33931 . & 1.00 & .14 & 1.1 \\
\hline 698 & & & & & & & & & & & & & & & \\
\hline & 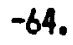 & & 20 & & & 0.000 & 0.04 & & 0.02 & 65603. & .04 & & .93 & .18 & .0 \\
\hline & & & & & & & & & & & 0.05 & & $\begin{array}{l}0.93 \\
0.89\end{array}$ & .14 & $\begin{array}{l}1.3 \\
1.1\end{array}$ \\
\hline & 60 & & 22 & 19 & 24 & 0.471 & 0.04 & & 0.02 & 35977 & 0.04 & 29867. & & & \\
\hline
\end{tabular}


WELL MMMBER $=42$

FIELD : CERRO PRIETO

RANGE : FROM 2674 TO 2708

COMPUTED DATA IS AS BELON:

$\begin{array}{ll}\text { Tmf }= & 75.000 \\ \text { RHOnf }= & 1.100 \\ \text { PHIOC }= & 0.07 \\ \text { FHINC } & 0.36 \\ \text { AN }= & 1.00 \\ \text { AM }=2.40\end{array}$

RUCLY $=0.10$

TDEEP $=400.0$

$R S H=1.00$
TABLE 42-3'

TDEEP IS USED

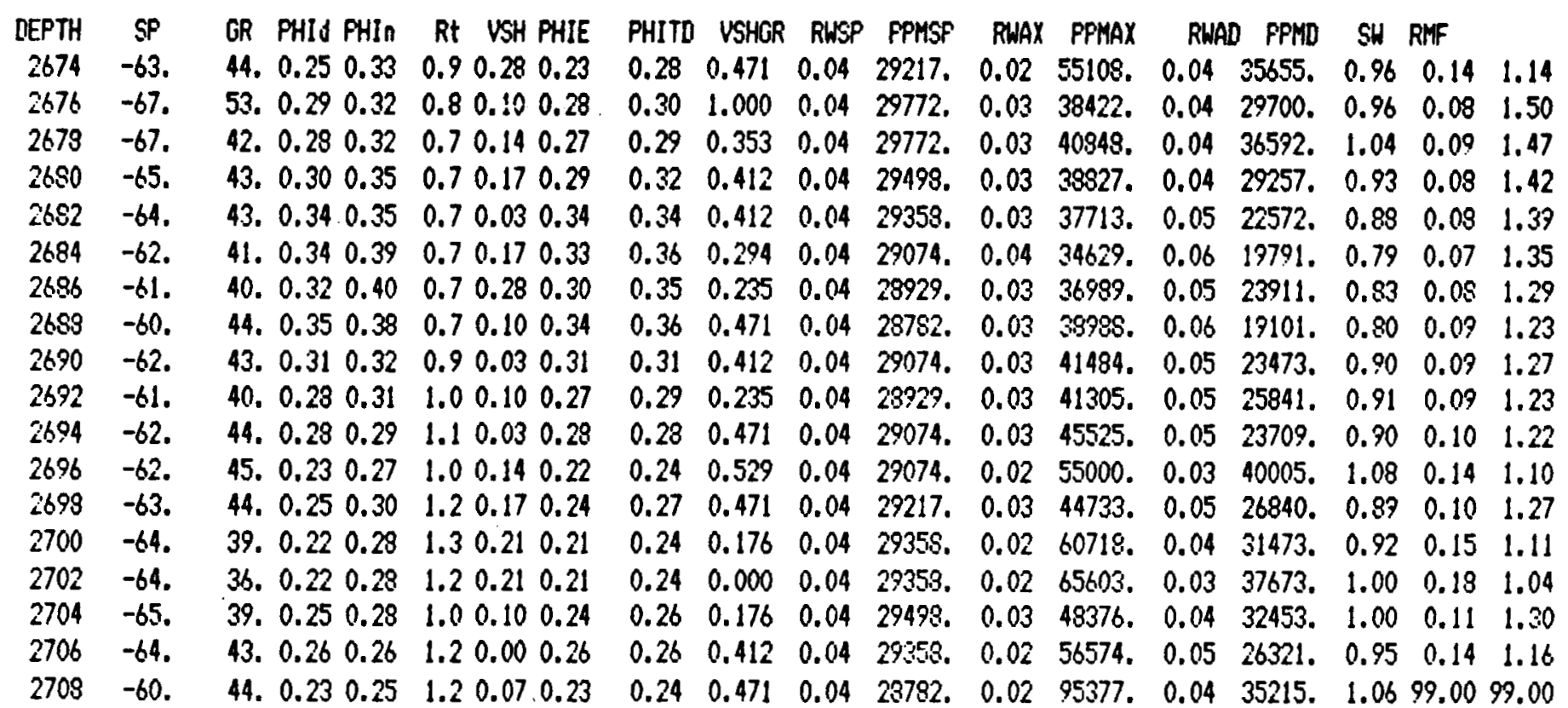


WELL MMMBER $=42$

FIELD : CERRO FRIETO

RANGE : FROM 3042 TO 3080

\begin{tabular}{|c|c|c|c|}
\hline \multirow{2}{*}{\multicolumn{2}{|c|}{ COMPUTED DATA IS AS BELOW: }} & \multicolumn{2}{|r|}{ TDEEP IS USED } \\
\hline & & $R_{m} f=$ & 0.300 \\
\hline $\operatorname{Tm} f=$ & 75.000 & & \\
\hline RHOmf $=$ & 1.100 & & \\
\hline FHIDC $=$ & 0.07 & & \\
\hline FHINC $=$ & 0.36 & & \\
\hline$A N=$ & 1.00 & & \\
\hline$A M=2$ & & & \\
\hline FWCLY $=$ & 0.10 & & \\
\hline TDEEP $=$ & 400.0 & & \\
\hline $\mathrm{RSH}=1$. & & & \\
\hline
\end{tabular}

\begin{tabular}{|c|c|c|c|c|c|c|c|c|c|c|c|c|c|c|c|}
\hline EPTH & $S P$ & GR & HIn & USH PHIE & PHITD & USHGR & RWSP & PFMSP & RiWAX & PMAX & RWHA & PPMD & SW & RMF & \\
\hline 3042 & 51. & 68. & .23 & 1.50 & 0.20 & 1.000 & 05 & 27383. & 03 & 48956 . & 03 & 197. & 1.05 & 0.14 & \\
\hline 8044 & & & .24 & & & 833 & 04 & . & 0.03 & & 03 & & 1.18 & 11 & \\
\hline 3046 & & & 0.26 & 0.22 & 0.24 & 0.500 & 0.04 & 29358. & 0.03 & 52023. & 0.03 & 5. & 1.18 & 12 & \\
\hline 3048 & 63 & & 0.25 & 0 & .24 & 0.542 & 0.04 & 29217. & 0.03 & 45168. & .03 & 49590. & 1.25 & .10 & 1.26 \\
\hline 3050 & by & & .25 & 0 & 0.24 & 0.667 & 0.04 & 28634. & 0.02 & 74039. & 0.03 & 39139. & 1.13 & .26 & 0.70 \\
\hline 3052 & 58. & & .240 .24 & $0.8 \quad 0.000 .24$ & 0.24 & 0.625 & 0.04 & 28484 . & 0.02 & 79216. & 0.03 & 41291. & 1.18 & 0.37 & 0.52 \\
\hline 3054 & 57. & & 0.230 .22 & $0.7 \quad 0.00 \quad 0.23$ & 0.23 & 0.458 & 0.04 & 28332. & 0.03 & 37668. & 0.03 & 53599. & 1.33 & 0.09 & 1.14 \\
\hline 3056 & 52. & & 0.230 .23 & $1.10 .00 \quad 0.23$ & 0.23 & 0.333 & 0.05 & 27546 . & 0.02 & 60124. & 0.04 & 35353. & 1.12 & 0.20 & 0.66 \\
\hline 3058 & -53. & 63 & 0.230 .23 & $\begin{array}{llll}1.3 & 0.00 & 0.23\end{array}$ & 0.23 & 0.792 & 0.05 & 27706. & 0.03 & 44557. & 0.04 & 28413. & 1.01 & 0.11 & 0.92 \\
\hline 3060 & -55 & & $0.20 \quad 0.24$ & 1.30 .140 .19 & 0.21 & 1.000 & 0.04 & 23023. & 0.03 & 39275. & 0.04 & 36223. & 1.03 & 0.09 & 1.05 \\
\hline 3062 & -55. & & $0.24 \quad 0.24$ & $\begin{array}{llll}1.2 & 0.00 & 0.24\end{array}$ & 0.24 & 0.500 & 0.04 & 28023. & 0.03 & 53825 . & 0.04 & 28531. & 1.01 & 0.15 & 0.86 \\
\hline 3064 & -60 & 67 & $0.21 \quad 0.24$ & $\begin{array}{llll}0.9 & 0.10 & 0.20\end{array}$ & 0.22 & 0.958 & 0.04 & 28782. & 0.04 & 34296. & 0.03 & 52766. & 1.25 & 0.07 & 1.28 \\
\hline 3066 & -61. & & 0.230 .24 & $0.70 .03 \quad 0.23$ & 0.23 & 0.625 & 0.04 & 28929. & 0.03 & 39212. & 0.02 & 59040 . & 1.35 & 0.09 & 1.26 \\
\hline 3069 & -65 . & & 0.240 .24 & $\begin{array}{llll}1.0 & 0.00 & 0.24\end{array}$ & 0.24 & 0.667 & 0.04 & 29498. & 0.02 & 60976. & 0.04 & 34282. & 1.07 & 0.15 & 1.15 \\
\hline 3070 & -65 . & & 0.240 .22 & $0.90 .00 \quad 0.24$ & 0.24 & 0.375 & 0.04 & 29498. & 0.05 & & 0.04 & & 1.10 & 05 & 1.59 \\
\hline 3072 & -63. & & 0.270 .24 & $0.70 .00 \quad 0.28$ & 0.28 & 0.000 & 0.04 & 29217. & 0.04 & & 0.04 & & 1.06 & 07 & 1.41 \\
\hline 3074 & -62 & & .270 .26 & $0.8 \quad 0.00 \quad 0.27$ & 0.27 & 0.167 & 0.04 & 29074. & 0.04 & & 0.04 & & 1.01 & 07 & 1.36 \\
\hline 307 & -61. & & .270 .27 & $\begin{array}{lll}0.8 & 0.00 & 0.27\end{array}$ & 0.27 & 0.208 & 0.04 & & 0.04 & 33904. & 0.04 & & 1.05 & 07 & 1.32 \\
\hline 307 & -59. & & & $\begin{array}{llll}0 & 0.00 & 0.29\end{array}$ & 0.29 & 0.333 & 0.04 & 28634 . & 0.04 & 33123. & 0.06 & 21586. & 0.88 & 0.07 & 1.26 \\
\hline & -56. & & 26 & & 1.2 & & דיi in & & 0.03 & & .04 & & 1.0 & .10 & \\
\hline
\end{tabular}


WELL MUHBER $=42$

FIELD : CERRO PRIETO

RANGE : FROM 3042 TO 3030

\section{COMPUTED DATA IS AS BELON:}

Taf =

75.000

RHOaf $=1.100$

PHIDC $=\quad 0.07$

PHINC $=0.36$

$A N=$

AY $=2.40$

RWCLY $=0.10$

TDEEP $=400.0$

$\mathrm{RSH}=1.00$

$\begin{array}{rr}\text { DEPTH } & \text { SP } \\ 3042 & -51 . \\ 3044 & -61 . \\ 3046 & -64 . \\ 3048 & -63 . \\ 3050 & -59 \\ 3052 & -58 . \\ 3054 & -57 . \\ 3056 & -52 . \\ 3053 & -53 . \\ 3060 & -55 . \\ 3062 & -55 . \\ 3064 & -60 . \\ 3066 & -61 . \\ 3068 & -65 . \\ 3070 & -65 . \\ 3072 & -63 . \\ 3074 & -62 . \\ 3076 & -61 . \\ 3073 & -59 \\ 3080 & -56 .\end{array}$

$\operatorname{Raf}=$

\section{TABLE 42-5'}

TDEEP IS USED
GR PHId PHIn RT USH PHIE $\begin{array}{llllll}68 . & 0.19 & 0.23 & 1.5 & 0.14 & 0.18\end{array}$ $\begin{array}{lllll}\text { 64. } 0.19 & 0.24 & 1.1 & 0.17 & 0.18\end{array}$ $\begin{array}{llllllll}\text { 56. } 0.23 & 0.26 & 0.8 & 0.10 & 0.22\end{array}$ $\begin{array}{llllll}57 . & 0.24 & 0.25 & 0.7 & 0.03 & 0.24\end{array}$ $\begin{array}{lllllll}60 . & 0.24 & 0.25 & 0.9 & 0.03 & 0.24\end{array}$ 59. $0.24 \quad 0.24 \quad 0.8 \quad 0.00 \quad 0.24$ 55. $0.23 \quad 0.22 \quad 0.7 \quad 0.00 \quad 0.23$ $\begin{array}{lllllll}\text { 52. } & 0.23 & 0.23 & 1.1 & 0.00 & 0.23\end{array}$ $\begin{array}{llllllllll} & 63 . & 0.23 & 0.23 & 1.3 & 0.00 & 0.23\end{array}$ 68. $0.20 \quad 0.24 \quad 1.3 \quad 0.140 .19$ 56. $0.24 \quad 0.24 \quad 1.2 \quad 0.00 \quad 0.24$ 67. $0.210 .24 \quad 0.90 .10 \quad 0.20$ 59. $0.23 \quad 0.24 \quad 0.70 .03 \quad 0.23$ 60. $0.240 .24 \quad 1.00 .00 \quad 0.24$ 53. $0.240 .22 \quad 0.90 .00 \quad 0.24$ 44. $0.27 \quad 0.24 \quad 0.7 \quad 0.00 \quad 0.28$ 48. $0.27 \quad 0.26 \quad 0.8 \quad 0.00 \quad 0.27$ 49. $0.27 \quad 0.27 \quad 0.8 \quad 0.00 \quad 0.27$ $\begin{array}{lllllllllllllll}\text { 52. } & 0.29 & 0.29 & 1.0 & 0.00 & 0.29\end{array}$ $\begin{array}{llllll}52 . & 0.26 & 0.26 & 1.0 & 0.00 & 0.26\end{array}$
PHITD VSHGR RUSP PPMSP RHAX PPMAX RHAD PPND SH RMF $\begin{array}{lllllllllllll}0.20 & 1.000 & 0.05 & 27383 . & 0.03 & 48856 & 0.03 & 44841 . & 1.13 & 0.14 & 0.80\end{array}$ $\begin{array}{llllllllllll}0.21 & 0.833 & 0.04 & 28929 & 0.03 & 47061 . & 0.02 & 63116 . & 1.27 & 0.11 & 1.16\end{array}$ $\begin{array}{lllllllllllllll}0.24 & 0.500 & 0.04 & 29358 . & 0.03 & 52023 . & 0.02 & 55366 . & 1.27 & 0.12 & 1.22\end{array}$ $\begin{array}{llllllllllll}0.24 & 0.542 & 0.04 & 29217 & 0.03 & 45168 . & 0.02 & 58290 . & 1.34 & 0.10 & 1.26\end{array}$ $\begin{array}{lllllllllll}0.24 & 0.667 & 0.04 & 28634 & 0.02 & 74039 & 0.03 & 45969 . & 1.22 & 0.26 & 0.70\end{array}$ $\begin{array}{llllllllllll}0.24 & 0.625 & 0.04 & 23484 . & 0.02 & 79216 . & 0.03 & 48526 & 1.27 & 0.37 & 0.52\end{array}$ $\begin{array}{llllllllllll}0.23 & 0.458 & 0.04 & 28332 & 0.03 & 37668 & 0.02 & 63299 & 1.43 & 0.09 & 1.14\end{array}$ $\begin{array}{lllllllllll}0.23 & 0.333 & 0.05 & 27546 . & 0.02 & 60124 . & 0.03 & 41719 . & 1.20 & 0.20 & 0.66\end{array}$ $\begin{array}{llllllllllll}0.23 & 0.792 & 0.05 & 27706 & 0.03 & 44557 . & 0.04 & 33493 & 1.09 & 0.11 & 0.92\end{array}$ $\begin{array}{lllllllllll}0.21 & 1.000 & 0.04 & 23023 & 0.03 & 39275 & 0.03 & 43407 . & 1.11 & 0.09 & 1.05\end{array}$ $\begin{array}{llllllllllll}0.24 & 0.500 & 0.04 & 28023 . & 0.03 & 53825 . & 0.04 & 33474 . & 1.08 & 0.15 & 0.86\end{array}$ $\begin{array}{llllllllllllll}0.22 & 0.958 & 0.04 & 28782 & 0.04 & 34296 . & 0.02 & 62909 . & 1.34 & 0.07 & 1.28\end{array}$ $\begin{array}{lllllllllllll}0.23 & 0.625 & 0.04 & 28929 & 0.03 & 39212 . & 0.02 & 69793 . & 1.46 & 0.09 & 1.26\end{array}$ $\begin{array}{llllllllllll}0.24 & 0.667 & 0.04 & 29498 . & 0.02 & 60976 . & 0.03 & 40254 & 1.15 & 0.15 & 1.15\end{array}$ $\begin{array}{llllllllllll}0.24 & 0.375 & 0.04 & 29498 . & 0.05 & 24524 . & 0.03 & 42838 & 1.18 & 0.05 & 1.59\end{array}$ $\begin{array}{lllllllllll}0.28 & 0.000 & 0.04 & 29217 . & 0.04 & 33360 . & 0.03 & 39361 . & 1.13 & 0.07 & 1.41\end{array}$ $\begin{array}{llllllllllll}0.27 & 0.167 & 0.04 & 29074 & 0.04 & 33707 . & 0.04 & 34710 . & 1.08 & 0.07 & 1.36\end{array}$ $\begin{array}{llllllllllll}0.27 & 0.208 & 0.04 & 28929 . & 0.04 & 33904 & 0.03 & 37058 . & 1.12 & 0.07 & 1.32\end{array}$ $\begin{array}{lllllllllll}0.29 & 0.333 & 0.04 & 28634 & 0.04 & 33123, & 0.05 & 24765 . & 0.94 & 0.07 & 1.26\end{array}$ $\begin{array}{llllllllllll}0.26 & 0.333 & 0.04 & 28178 & 0.03 & 43124 & 0.04 & 33632 & 1.08 & 0.10 & 1.04\end{array}$ 
WELL NUMBER $=42$

FIELD : CERRO PRIETO

RANGE : FROM 3042 TO 3080

$\begin{array}{lc}\text { COMPUTED } & \text { DATA IS AS } \\ \text { TMF }= & 75.000 \\ \text { RHOMf }= & 1.100 \\ \text { PHIDC }= & 0.07 \\ \text { PHINC }= & 0.36 \\ \text { AN }= & 1.00 \\ \text { AM }=2.50 \\ \text { RWCLY }=0.10 \\ \text { TDEEP }=400.0 \\ \text { RSH }=1.00\end{array}$

\begin{tabular}{|c|c|c|c|c|c|c|c|c|c|c|c|c|c|c|}
\hline DEFTH & $S P$ & in & IE & & SHGR & ISP & PFMSP & RWAX & MAX & & PPD & $\mathrm{in}$ & RMF & \\
\hline 3042 & 1. & & 1 & 20 & .000 & 0.05 & 383. & 0.03 & 48856. & 0.03 & 54047. & 1.22 & 0.14 & \\
\hline 3044 & bl. & 190.24 & 1.10 .1 & 0.21 & 0.833 & 0.04 & 28929. & 0.03 & 47061. & 0.02 & 76027. & 1.37 & 0.11 & 1. \\
\hline 3046 & 34. & 0.26 & 0.8 & 24 & 0.500 & 0.04 & 29358. & 0.03 & 52023. & 0.02 & 65331 . & 1.36 & 0.12 & 1.22 \\
\hline 3048 & 63. & 57. & 0.70 .030 .24 & 0.24 & 0.542 & 0.04 & 29217. & 0.03 & 45168. & 0.02 & $6855 \%$. & 1.44 & 10 & 26 \\
\hline 3050 & 19. & 0.25 & 0.90 .030 & 0.24 & 0.667 & 0.04 & 28634. & 0.02 & 74039. & 0.03 & 54018. & 1.30 & .26 & 0.70 \\
\hline 3052 & 58. & 0.24 & 0.80 .000 .24 & .24 & 0.625 & 0.04 & 28484. & 0.02 & 79216. & 0.02 & 7072. & 1.36 & .37 & 0.52 \\
\hline 3054 & 57. & 0.230 .22 & $0.70 .00 \quad 0.23$ & 0.23 & 0.458 & 0.04 & 28332. & 0.03 & 3768.8. & 0.02 & 74812. & 1.54 & .09 & 1.14 \\
\hline 3056 & 52. & 52. 0.230 .23 & 1.10 .000 .23 & 0.23 & 0.333 & 0.05 & 27546. & 0.02 & 60124. & 0.03 & 49269. & 1.29 & 0.20 & 0.66 \\
\hline 3058 & 53. & 63. 0.230 .23 & $1.30 .00 \quad 0.23$ & 0.23 & 0.792 & 0.05 & 27706. & 0.03 & 44557. & 0.03 & 39513. & 1.17 & 0.11 & 0.92 \\
\hline 3060 & -55 & 68. 0.200 .24 & 1.30 .140 .19 & 0.21 & 1.000 & 0.04 & 28023. & 0.03 & 39275. & 0.03 & 52008. & 1.20 & 0.09 & 1.05 \\
\hline 3062 & -55 & 56. 0.240 .24 & $1.20 .00 \quad 0.24$ & 0.24 & 0.500 & 0.04 & 28023. & 0.03 & 53825. & 0.03 & 39301. & 1.16 & 0.15 & 0.86 \\
\hline 31004 & -60 & 67. $0.21 \quad 0.24$ & 0.90 .100 .20 & 0.22 & 0.958 & 0.04 & 28782. & 0.04 & 34296. & 0.02 & 75027. & 1.45 & 0.07 & 1.28 \\
\hline 3056 & -61. & 0.230 .24 & 0.70 .030 .23 & 0.23 & 0.625 & 0.04 & 28929. & 0.03 & 39212 . & 0.02 & 82534. & 1.56 & 0.09 & 1.26 \\
\hline 3068 & -65. & $\begin{array}{lll}60.24 & 0.24\end{array}$ & 1.00 .000 .24 & 0.24 & 0.667 & 0.04 & 29498. & 0.02 & 60976. & 0.03 & 47303. & 1.23 & 0.15 & 1.15 \\
\hline 3070 & -65. & 0.240 .22 & 0.90 .000 .24 & 0.24 & 0.375 & 0.04 & 29498. & 0.05 & 24524. & 0.03 & 50239. & 1.27 & 0.05 & 1.59 \\
\hline 3072 & -63. & .270 .24 & 0.70 .000 .28 & 0.28 & 0.000 & 0.04 & 29217. & 0.04 & 33360. & 0.03 & 44338. & 1.20 & 0.07 & 1.41 \\
\hline 2074 & -62. & 0.270 .26 & $0.8 \quad 0.00 \quad 0.27$ & 0.27 & 0.167 & 0.04 & 29074. & 0.04 & 33707. & 0.03 & 40181. & 1.16 & 0.07 & 1.36 \\
\hline 3076 & -61. & 49. & $0.8 \quad 0.00 \quad 0.27$ & 0.27 & 0.208 & 0.04 & 29929. & 0.04 & 33904. & 0.03 & 42954. & 1.19 & 0.07 & 1.32 \\
\hline 3078 & -59. & .29 & $1.0 \quad 0.00 \quad 0.29$ & 0.29 & 0.333 & 0.04 & 28634. & 0.04 & 3312 & 0.04 & 29428. & 1.00 & 0.07 & 1.26 \\
\hline & -56. & 0.260 .26 & 1.00 .000 .26 & 0.26 & 0.333 & 0.04 & 28178. & 0.03 & & 0.03 & 39133. & 1.16 & 0.10 & 1.04 \\
\hline
\end{tabular}

$R_{m f}=0.300$

$$
\begin{array}{lc}
\text { Tmf }= & 75.000 \\
\text { RHOmf }= & 1.100 \\
\text { PHIDC }= & 0.07 \\
\text { PHINC }= & 0.36 \\
\text { AN }= & 1.00 \\
\text { AM }=2.50 & =0.10 \\
\text { RWCLY }= & 0.10 \\
\text { TDEEP }= & 400.0 \\
\text { RSH }=1.01
\end{array}
$$

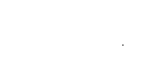




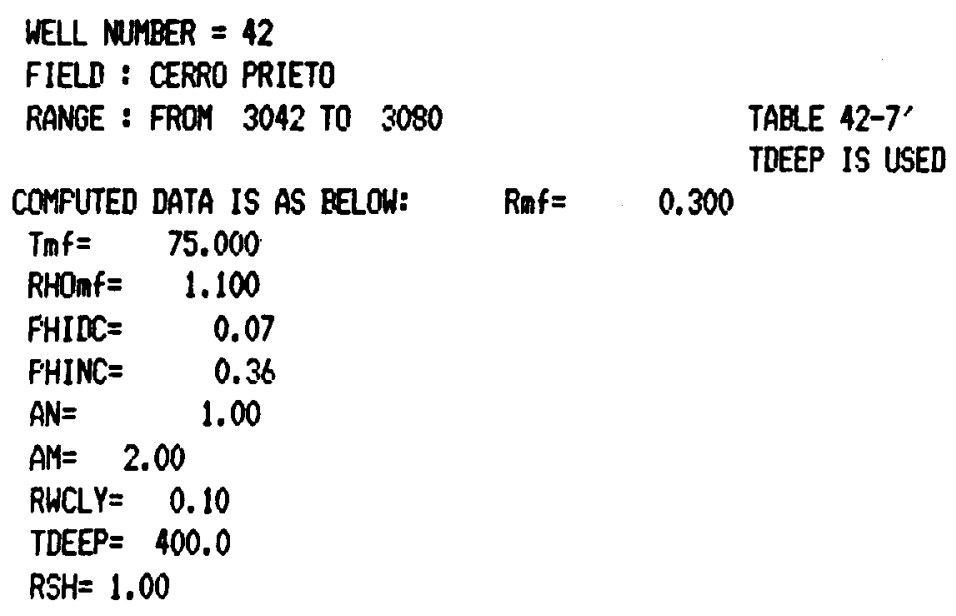

\begin{tabular}{|c|c|c|c|c|c|c|c|c|c|c|c|c|c|c|}
\hline EPTH & SP & PHIn & SSH PHIE & PHITD & VSHGR & RWSP & PPMSP & RWAX & PPMAX & & FPMD & & RWF & \\
\hline 3042 & -51. & 190.23 & 1.50 .140 .18 & 0.20 & 1.000 & 0.05 & 27383. & 0.03 & 48856. & 0.06 & 21165. & 0.83 & 0.14 & 0.80 \\
\hline 34 & -61. & 170.24 & 1.10 .170 .18 & 0.21 & 0.833 & 0.04 & 28929. & 0.03 & 47061. & 0.04 & 29891. & 0.94 & 0.11 & 1.16 \\
\hline 3046 & -64. & $56.0 .23 \quad 0.26$ & $\begin{array}{llll}0.8 & 0.10 & 0.22\end{array}$ & 0.24 & 0.500 & 0.04 & 29358. & 0.03 & 52023. & 0.04 & 28625 . & 0.95 & 0.12 & 1.22 \\
\hline $\begin{array}{l}3048 \\
3050\end{array}$ & $\begin{array}{l}-63 . \\
-59 .\end{array}$ & $\begin{array}{lll}57 . & 0.24 & 0.25 \\
60 . & 0.24 & 0.25\end{array}$ & & $\begin{array}{l}0.24 \\
0.24\end{array}$ & $\begin{array}{l}0.542 \\
0.667\end{array}$ & $\begin{array}{l}0.04 \\
0.04\end{array}$ & $\begin{array}{l}29217 . \\
28634 .\end{array}$ & $\begin{array}{l}0.03 \\
0.02\end{array}$ & $\begin{array}{l}45168 . \\
74039 .\end{array}$ & $\begin{array}{l}0.04 \\
0.05\end{array}$ & $\begin{array}{l}30637 . \\
24237 .\end{array}$ & $\begin{array}{l}1.01 \\
0.92\end{array}$ & $\begin{array}{l}0.10 \\
0.26\end{array}$ & $\begin{array}{l}1.26 \\
0.70\end{array}$ \\
\hline 052 & -58. & 59. 0.240 .24 & $\begin{array}{llll}0.8 & 0.00 & 0.24\end{array}$ & 0.24 & 0.625 & 0.04 & 28484. & 0.02 & 79216. & 0.05 & 25551. & 0.95 & 0.37 & 0.52 \\
\hline 054 & -57 & 55. $0.23 \quad 0.22$ & $\begin{array}{llll}0.7 & 0.00 & 0.23\end{array}$ & 0.23 & 0.458 & 0.04 & 28332. & 0.03 & 37668. & 0.04 & 32694 . & 1.07 & 0.09 & 1.14 \\
\hline 15 & -52 & & & 0.23 & 0.333 & 0.05 & 27546. & 0.02 & 60124. & 0.06 & 21616. & 0.90 & 0.20 & 0.66 \\
\hline & $\begin{array}{l}-53 . \\
-55 .\end{array}$ & $\begin{array}{lll}\text { 63. } & 0.23 & 0.23 \\
68 . & 0.20 & 0.24\end{array}$ & $\begin{array}{lll}1.3 & 0.00 & 0.23 \\
1.3 & 0.14 & 0.19\end{array}$ & $\begin{array}{l}0.23 \\
0.21\end{array}$ & $\begin{array}{l}0.792 \\
1.000\end{array}$ & $\begin{array}{l}0.05 \\
0.04\end{array}$ & $\begin{array}{l}27706 . \\
23023 .\end{array}$ & $\begin{array}{l}0.03 \\
0.03\end{array}$ & & $\begin{array}{l}0.07 \\
0.06\end{array}$ & $\begin{array}{l}17427 . \\
20994 .\end{array}$ & $\begin{array}{l}0.81 \\
0.83\end{array}$ & $\begin{array}{l}0.11 \\
0.09\end{array}$ & $\begin{array}{l}0.92 \\
1.05\end{array}$ \\
\hline $06 ?$ & -55. & $\begin{array}{lll}56 . & 0.24 & 0.24\end{array}$ & $\begin{array}{llll}1.2 & 0.00 & 0.24\end{array}$ & 0.24 & 0.500 & 0.04 & 29023. & 0.03 & 5382 & 0.07 & 17746. & 081 & & \\
\hline 6. & -60 & 67. 0.210 .24 & $\begin{array}{llll}0.9 & 0.10 & 0.20\end{array}$ & 0.22 & 0.958 & 0.04 & 28782. & 0.0 & 342 & 0.0 & & 0. & & \\
\hline 066 & -61 . & $\begin{array}{lll}59 . & 0.23 & 0.24\end{array}$ & $\begin{array}{lll}0.7 & 0.03 & 0.23\end{array}$ & 0.23 & 0.625 & 0.04 & 28929. & 0.03 & 39212. & 0.04 & 35898. & 1.09 & 0.09 & 1.26 \\
\hline 068 & -65. & 60. 0.240 .24 & $\begin{array}{llll}1.0 & 0.00 & 0.24\end{array}$ & 0.24 & 0.667 & 0.04 & 29498. & 0.02 & 60976. & 0.06 & 21269. & 0.86 & 0.15 & 1.15 \\
\hline 07 & -65 & 53. $0.24 \quad 0.22$ & 0.90 .000 .24 & 0.24 & 0.375 & 0.04 & 29498 . & 0.05 & 24524. & 0.05 & 22809. & 0.89 & 0.05 & 1.59 \\
\hline & & & 0.70. & 0.28 & 0.000 & 0.04 & 29217. & 0.04 & 33360 . & 0.06 & 21624. & 0.87 & 0.07 & 1.41 \\
\hline 3074 & -62. & 43. 0.270 .26 & $\begin{array}{llll}0.8 & 0.00 & 0.27\end{array}$ & 0.27 & 0.167 & 0.04 & 29074. & 0.04 & 33707. & 0.06 & 19447. & 0.83 & 0.07 & 1.36 \\
\hline 3076 & -61. & 49. 0.270 .27 & $\begin{array}{llll}0.8 & 0.00 & 0.27\end{array}$ & 0.27 & 0.208 & 0.04 & 28929. & 0.04 & 33904 . & 0.06 & 20658. & 0.86 & 0.07 & 1.32 \\
\hline 978 & -59. & 52. 0.290 .28 & $\begin{array}{llll}1.0 & 0.00 & 0.29\end{array}$ & 0.29 & 0.333 & 0.04 & 23634. & 0.04 & 33123. & 0.08 & 14342. & 0.73 & 0.07 & 1.26 \\
\hline 3080 & -56. & 52. 0.260 .26 & $\begin{array}{lll}1.0 & 0.00 & 0.26\end{array}$ & 0.26 & 0.333 & 0.04 & 28178 & 0.03 & 43124. & 0.07 & 18469. & 0.83 & 0.10 & 1.04 \\
\hline
\end{tabular}


WELL NUMBER $=42$

FIELD : CERRO PRIETO

RANGE : FROM 3814 TO 3840

COMPUTED OATA IS AS BELOW:

Tinf $=75.000$

RHOmf $=1.100$

PHIDC $=0.07$

PHINC $=0.36$

$A N=1.00$

$A M=2.30$

FWCLY $=0.10$

TDEEP $=260.0$

$\mathrm{RSH}=2.00$

\begin{tabular}{|c|c|c|c|c|c|c|c|c|c|c|c|c|c|c|c|}
\hline $\begin{array}{l}\text { DEPTH } \\
3814\end{array}$ & $\begin{array}{l}\text { SP } \\
-60 .\end{array}$ & $\begin{array}{l}\text { GR } \\
72 .\end{array}$ & $\begin{array}{l}\text { PHId FHIn } \\
0.230 .19\end{array}$ & $\begin{array}{ccc}\text { Rt VSH PHIE } \\
2.0 & 0.00 & 0.24\end{array}$ & $\begin{array}{l}\text { PHITD } \\
0.24\end{array}$ & $\begin{array}{l}\text { VSHGR } \\
0.875\end{array}$ & $\begin{array}{l}\text { FiWP } \\
0.05\end{array}$ & $\begin{array}{l}\text { PFMSP } \\
43939 .\end{array}$ & $\begin{array}{l}\text { FWAX } \\
0.04\end{array}$ & $\begin{array}{l}\text { PPMAX } \\
45573 .\end{array}$ & & $\begin{array}{l}\text { PFPID } \\
25449 .\end{array}$ & $\begin{array}{l}\text { SW } \\
0.78\end{array}$ & $\begin{array}{l}\text { RMF } \\
0.10\end{array}$ & 1.63 \\
\hline 3816 & -63. & 75. & 250.19 & 1.80 .000$. & 0.26 & 1.000 & 0.04 & 44925. & 0.04 & 47034. & 0.08 & 22666 . & 0.74 & 0.10 & 1.78 \\
\hline 3816 & -64. & 6 & 30. & & 0.24 & 0.625 & 0.04 & 45229. & 0.04 & 56054. & 0.06 & 9665. & & .12 & \\
\hline $382 C$ & -64. & 59. & 230.18 & 1.6 & 0.24 & 0.333 & 0.04 & 45229. & 0.03 & 60298. & 0.06 & 31413. & 0.85 & 0.13 & 1.68 \\
\hline 382 & 64. & 54. & 0 & 1.8 & 0.21 & 0.125 & 0.04 & 45229. & 0.04 & 55834. & 0.05 & 39843. & 0.95 & 0.12 & 1.73 \\
\hline 382 & 64. & 60. & 0. & 1.9 & 0.23 & 0.375 & 0.04 & 45057. & 0.04 & 52634. & 0.07 & 28349. & 0.81 & 0.11 & 1.77 \\
\hline 882 & 64. & 62. & 0.220 .18 & 1.70 .000 .23 & 0.23 & 0.459 & 0.04 & 45057. & 0.04 & 51994. & 0.06 & 32958. & 0.87 & 0.11 & 1.77 \\
\hline 332 & -65. & 59. & $0.22 \quad 0.19$ & 1.80 .000 .23 & 0.23 & 0.333 & 0.04 & 45354. & 0.04 & 45809. & 0.06 & 31969. & 0.86 & 0.09 & 1.91 \\
\hline 383 & -64. & 59. & 0.240 .20 & $\begin{array}{lll}1.7 & 0.00 & 0.25\end{array}$ & 0.25 & 0.333 & 0.04 & 45057. & 0.04 & 52165. & 0.07 & 26419. & 0.79 & 0.11 & 1.77 \\
\hline 83 & 64. & 57. & 0.230 .20 & $\begin{array}{lll}1.7 & 0.00 & 0.24\end{array}$ & 0.24 & 0.250 & 0.04 & 45057. & 0.04 & 56159. & 0.06 & 31891. & 0.86 & 0.12 & 1.73 \\
\hline & -65. & 52. & 0.260 .19 & 1.60 & 0.28 & 0.042 & 0.04 & 45354. & 0.03 & 63308. & 0.08 & 227 & 0.74 & 0.14 & 1.70 \\
\hline & -65. & 51 & $0.26 \quad 0.19$ & 1.50 .0 & 0.28 & 0.000 & 0.04 & & 0.04 & & 0.08 & & 0.7 & 0.11 & 1.80 \\
\hline & 34 & 57 & & 1.50 .000$. & 0.26 & 0.250 & 0.04 & 44886. & 0.04 & & 0.07 & & 0.79 & 0.12 & 1.72 \\
\hline & -54 . & & 0.230 .19 & $1.90 .00 \quad 0.24$ & 0.24 & 0.875 & 0.05 & 41711. & 0.05 & 43479. & 0.07 & 25903. & 0.81 & 0.10 & 1.34 \\
\hline
\end{tabular}


HELL MUMBER $=42$

FIELD : CERRO PRIETO

FANGE : FROM 3814 TO 3840

\section{COMPUTED DATA IS AS BELON:}

Tmf $=$

PHIDC $=0.07$

FHINC $=\quad 0.36$

$A N=\quad 1.00$

AM $=2.30$

RHCLY $=0.10$

TDEEP $=400.0$

RSH $=2.00$
TABLE 42-9'

TUEEF IS USED
Raff=

0.300

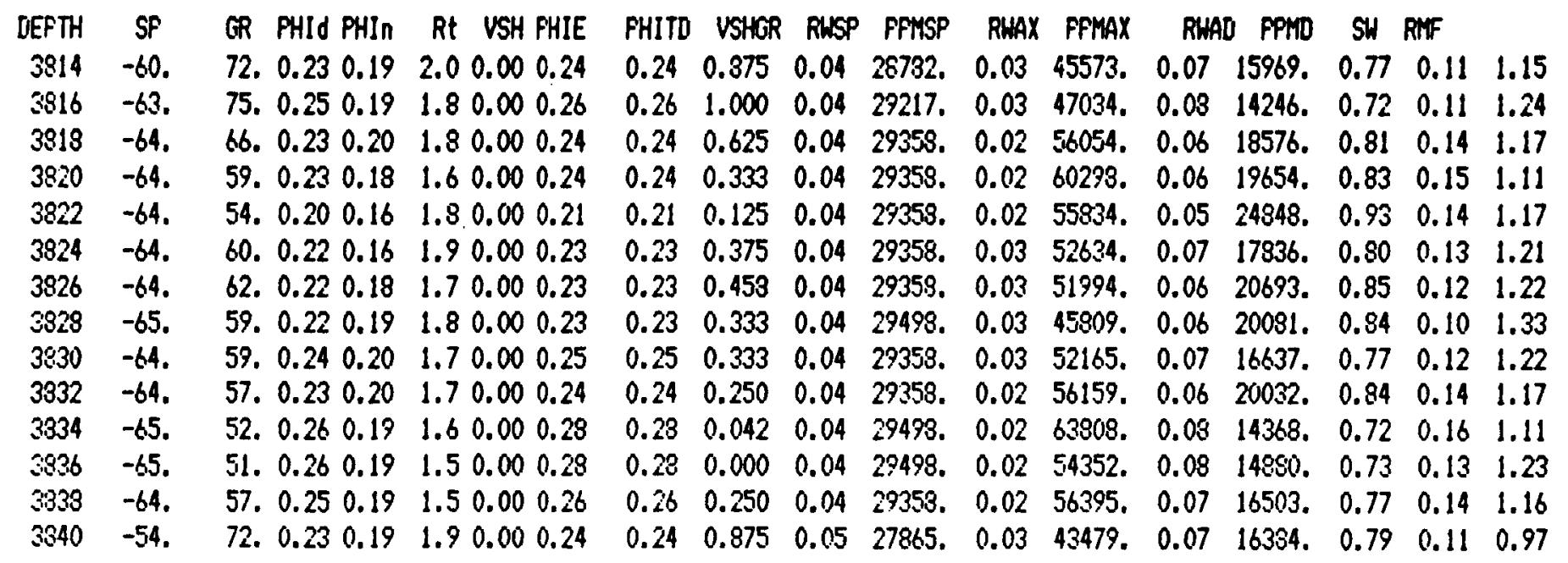


WELL NUMBER $=42$

FIELD : CERRO FRIETO

RANGE : FROM 3314 TO 3840

\section{COMPUTED DATA IS AS BELOW:}

Taf $=\quad 75.000$

RHOmf $=1.100$

FHIDC $=0.07$

PHINC $=0.36$

$A N=1.00$

$A M=2.30$

FWCLY $=0.10$

TDEEP $=400.0$

RSH $=2.00$

PHITD VSHGR RWGF FPMSP RWAX PPMAX RWAD PFMD SW RMF

$\begin{array}{llllllllllll}-60 . & 72 . & 0.23 & 0.19 & 2.0 & 0.00 & 0.24\end{array}$

$\begin{array}{lllllllllllll}-63 . & 75 . & 0.25 & 0.19 & 1.3 & 0.00 & 0.26\end{array}$

$\begin{array}{llllllllllll}0.24 & 0.875 & 0.05 & 24533 & 0.05 & 25683 . & 0.07 & 15969 & 0.02 & 0.11 & 1.15\end{array}$

$\begin{array}{lllllll}-64 . & 66 . & 0.23 & 0.20 & 1.8 & 0.00 & 0.24\end{array}$

$\begin{array}{llllllllll}-64 . & 59 . & 0.23 & 0.18 & 1.6 & 0.00 & 0.24\end{array}$

$\begin{array}{lllllllllll}0.26 & 1.000 & 0.05 & 25096 . & 0.05 & 26492 . & 0.08 & 14246 . & 0.77 & 0.11 & 1.24\end{array}$

$\begin{array}{lllllllllll}0.24 & 0.625 & 0.05 & 25230 . & 0.04 & 31482 . & 0.06 & 18576 . & 0.37 & 0.14 & 1.17\end{array}$

-64. 54. $0.200 .16 \quad 1.80 .000 .21$

$\begin{array}{lllllllllll}0.24 & 0.333 & 0.05 & 25280 . & 0.04 & 33825 & 0.06 & 19654 . & 0.39 & 0.15 & 1.11\end{array}$

$\begin{array}{llllllll}-64 . & 60 . & 0.22 & 0.16 & 1.9 & 0.00 & 0.23\end{array}$

$\begin{array}{llllllllllll}0.21 & 0.125 & 0.05 & 25280, & 0.04 & 31361 . & 0.05 & 24848 . & 0.99 & 0.14 & 1.17\end{array}$

$\begin{array}{llllllllll}-64 . & 62 . & 0.22 & 0.18 & 1.7 & 0.00 & 0.23\end{array}$

$\begin{array}{llllllllllll}0.23 & 0.375 & 0.05 & 25280 & 0.04 & 29551 & 0.07 & 17836 . & 0.85 & 0.13 & 1.21\end{array}$

$\begin{array}{llllllll}-65 . & 59 . & 0.22 & 0.19 & 1.3 & 0.00 & 0.23\end{array}$

$\begin{array}{lllllllllll}0.23 & 0.458 & 0.05 & 25280 . & 0.04 & 29233 . & 0.06 & 20693 . & 0.91 & 0.12 & 1.22\end{array}$

$\begin{array}{lllllllllll}-64 . & 59 . & 0.24 & 0.20 & 1.7 & 0.00 & 0.25\end{array}$

$\begin{array}{lllllllllll}-64 . & 57 . & 0.23 & 0.20 & 1.7 & 0.10 & 0.24\end{array}$

$\begin{array}{lllllllllll}0.23 & 0.333 & 0.05 & 25463 & 0.05 & 25613 . & 0.06 & 20081 . & 0.90 & 0.10 & 1.33\end{array}$

$\begin{array}{llllllll}-65 . & 52 . & 0.26 & 0.19 & 1.6 & 0.00 & 0.28\end{array}$

$\begin{array}{llllllllllllll}0.353 & 0.03 & 0.05 & 25230 & 0.04 & 29333 & 0.07 & 16637 & 0.33 & 0.12 & 1.22\end{array}$

$\begin{array}{lllllllllll}0.24 & 0.250 & 0.05 & 25280 . & 0.04 & 31540 . & 0.06 & 20032 . & 0.30 & 0.14 & 1.17\end{array}$

$\begin{array}{llllllll}-65 . & 51 . & 0.26 & 0.19 & 1.5 & 0.00 & 0.28\end{array}$

$\begin{array}{llllllllllll}0.28 & 0.042 & 0.05 & 25463 . & 0.04 & 35761 . & 0.03 & 14363 . & 0.77 & 0.16 & 1.11\end{array}$

$\begin{array}{llllllll}-64 . & 57 . & 0.25 & 0.19 & 1.5 & 0.00 & 0.26\end{array}$

$\begin{array}{llllllllllll}0.28 & 0.000 & 0.05 & 25463 & 0.04 & 30542 . & 0.08 & 14880 . & 0.78 & 0.13 & 1.23\end{array}$

$\begin{array}{lllllll}-54 . & 72: & 0.23 & 0.19 & 1.9 & 0.00 & 0.24\end{array}$

$\begin{array}{llllllllllll}0.26 & 0.250 & 0.05 & 25280 . & 0.04 & 31670 . & 0.07 & 16503 . & 0.82 & 0.14 & 1.16\end{array}$ $\begin{array}{llllllllllllllll}0.24 & 0.875 & 0.05 & 23363 . & 0.05 & 24521 . & 0.07 & 16384 . & 0.85 & 0.11 & 0.97\end{array}$ 